Florida International University FIU Digital Commons

\title{
Design and Synthesis of 4-N-Alkanoyl and 4-N- Alkyl Gemcitabine Analogues Suitable for Positron Emission Tomography
}

Jesse E. Pulido

jpuli004@fiu.edu

DOI: $10.25148 /$ etd.FI14040869

Follow this and additional works at: https://digitalcommons.fiu.edu/etd

Part of the Carbohydrates Commons, Cell Biology Commons, Diagnosis Commons, Heterocyclic Compounds Commons, Nucleic Acids, Nucleotides, and Nucleosides Commons, and the Therapeutics Commons

\section{Recommended Citation}

Pulido, Jesse E., "Design and Synthesis of 4-N-Alkanoyl and 4-N-Alkyl Gemcitabine Analogues Suitable for Positron Emission Tomography" (2014). FIU Electronic Theses and Dissertations. 1232.

https://digitalcommons.fiu.edu/etd/1232 


\title{
FLORIDA INTERNATIONAL UNIVERSITY
}

Miami, Florida

\section{DESIGN AND SYNTHESIS OF 4- $N$-ALKANOYL AND 4- $N$-ALKYL GEMCITABINE}

ANALOGUES SUITABLE FOR POSITRON EMISSION TOMOGRAPHY

\author{
A dissertation submitted in partial fulfillment of \\ the requirements for the degree of \\ DOCTOR OF PHILOSOPHY \\ in \\ CHEMISTRY \\ by
}

Jesse E. Pulido 
To: Dean Kenneth G. Furton

College of Arts and Sciences

This dissertation, written by Jesse E. Pulido, and entitled Design and Synthesis of 4-N-Alkanoyl and 4-N-Alkyl Gemcitabine Analogues Suitable for Positron Emission Tomography, having been approved in respect to style and intellectual content, is referred to you for judgment.

We have read this dissertation and recommend that it be approved.

$\begin{array}{r}\hline \text { Watson Lees } \\ \hline \text { Joong-ho Moon } \\ \hline \text { Bruce McCord } \\ \hline \text { Anthony McGoron } \\ \hline \text { Stanislaw F. Wnuk, Major Professor }\end{array}$

Date of Defense: March 6, 2014

The dissertation of Jesse E. Pulido is approved.

Dean Kenneth G. Furton College of Arts and Sciences

Dean Lakshmi N. Reddi University Graduate School

Florida International University, 2014 
(C) Copyright 2014 by Jesse E. Pulido All rights reserved. 


\section{DEDICATION}

I would like to dedicate this dissertation firstly to God, who blessed me with a loving and supporting family and for providing me the strength and wisdom to persevere. Also to my family (all of you), who always encouraged me to do my best and reach for the stars. 


\section{ACKNOWLEDGMENTS}

First and foremost I would like to thank my mentor Dr. Stanislaw F. Wnuk for providing me the opportunity to work with him; you are a true inspiration and friend. Words cannot express my thanks for all the guidance and lessons that you have provided over the years towards my personal and professional development. I would also like to give my thanks to my committee members Watson Lees, Joong-ho Moon, Bruce McCord and Anthony McGoron for their support throughout my doctoral studies. I would also like to extend my gratitude towards the Department of Chemistry and Biochemistry at Florida International University, the National Institute of Health (NIGMS; R25 GM61347) and to the MBRS RISE program and staff for their support.

I would like to thank my collaborators whom without this dissertation would not be possible. A special thank you to Alok Deoraj, Deodutta Roy and the rest of the Roy group here at FIU who opened up their lab and taught me cell culture; you are the magic. Thanks to Alvaro Velandia for his help and guidance with the flow cytometry work and to Smitha Nair and Cheppail Ramachandran from the Department of Pathology at Miami Children's Hospital for their cell culture work. Many thanks to Jan Balzarini from the Rega Institute for Medical Research in Leuven, Belgium who defined the cytostatic activity for my analogues and for further probed their mechanism of action. Thanks to

Caius Radu and Nagichettiar Satyamurthy from the Crump Institute for Molecular Imaging in the University of California Los Angeles for their work with the 18-fluorine labeling. Many thanks to Alex Amor-Acoarasa and Anthony McGoron from the Department of Biomedical Engineering here at FIU for their continual support and efforts, which made the 68-gallium labeling experiments a success. 
I would like to thank my lab mates and colleagues with whom I have shared many triumphs and weathered many a storm. A special thanks to Dr. Adam Sobczak for his teachings and support. Thank you Pablo Sacasa, Yong Liang, Mukesh Mudgal and Ramanjaneyulu Rayala for their positive feedback and synthetic contributions.

I would like to thank my loving family for their unending support throughout this chapter in my life. My parents Oscar and Zoraida Pulido, for raising me to be who I am today. My brothers Alex and Oscar who have been a big influence (albeit questionable at times) in my life and helped shape me into who I am. To Carlos and Silvia, who opened their hearts and home to me and who provided me with unending support and encouragement. To my sisters Molly and Janelle, you are very special and I am lucky to have you in my life. Finally, and most importantly, I would like to thank Jessica, my better half. Without you a great many things, including this dissertation, would not have been possible. Thank you for your love, encouragement and patience these many years and for making them the best years of my life. 


\title{
ABSTRACT OF THE DISSERTATION \\ DESIGN AND SYNTHESIS OF 4- $N$-ALKANOYL AND 4- $N$-ALKYL GEMCITABINE \\ ANALOGUES SUITABLE FOR POSITRON EMISSION TOMOGRAPHY
}

\author{
by
}

Jesse E. Pulido

Florida International University, 2014

Miami, Florida

\section{Professor Stanislaw F. Wnuk, Major Professor}

Gemcitabine is a highly potent chemotherapeutic nucleoside agent used in the treatment of several cancers and solid tumors. However, it is therapeutically limitated because of toxicity to normal cells and its rapid intracellular deamination by cytidine deaminase into the inactive uracil derivative. Modification at the 4- $(N)$ position of gemcitabine's exocyclic amine to an -amide functionality is a well reported prodrug strategy which has been that confers a resistance to intracellular deamination while also altering pharmacokinetics of the parent drug. Coupling of gemcitabine to carboxylic acids with varying terminal moieties afforded the $4-N$-alkanoylgemcitabines whereas reaction of 4- $\mathrm{N}$-tosylgemcitabine with the corresponding alkyl amines gave the 4-Nalkylgemcitabines. The 4- $N$-alkanoyl and 4-N-alkyl gemcitabine analogues with a terminal hydroxyl group on the $4-N$-alkanoyl or $4-N$-alkyl chain were efficiently fluorinated either with diethylaminosulfur trifluoride or under conditions that are compatible with the synthetic protocols for ${ }^{18} \mathrm{~F}$ labeling, such as displacement of the corresponding mesylate with $\mathrm{KF} / \mathrm{Kryptofix} \quad 2.2 .2$. The 4- $\mathrm{N}$-alkanoylgemcitabine analogues displayed potent cytostatic activities against murine and human tumor cell 
lines with $50 \%$ inhibitory concentration $\left(\mathrm{IC}_{50}\right)$ values in the range of low $\mathrm{nM}$, whereas cytotoxicity of the $4-N$-alkylgemcitabine derivatives were in the low to modest $\mu \mathrm{M}$ range. The cytostatic activity of the 4- $\mathrm{N}$-alkanoylgemcitabines was reduced by several orders of magnitude in the 2'-deoxycytidine kinase (dCK)-deficient CEM/dCK- cell line while the $4-\mathrm{N}$-alkylgemcitabines were only lowered by $2-5$ times. None of the $4-\mathrm{N}$-modified gemcitabines were found to be substrates for cytosolic $\mathrm{dCK}$, however all were found to inhibit DNA synthesis. As such, the 4- $N$-alkanoyl gemcitabine derivatives likely need to be converted to gemcitabine prior to achieving their significant cytostatic potential, whereas the $4-N$-alkylgemcitabines reach their modest activity without "measurable" conversion to gemcitabine. Thus, the $4-N$-alkylgemcitabines provide valuable insight on the metabolism of 4- $N$-modified gemcitabine prodrugs. 


\section{TABLE OF CONTENTS}

CHAPTER

PAGE

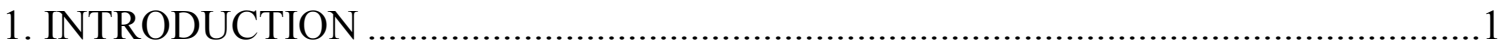

1.1. Nucleoside analogues and their application as chemotherapeutic agents...............1

1.1.1. Nucleoside analogues for the treatment of cancer.....................................

1.1.2. Anticancer activity of fluorinated pyrimidine nucleoside analogues...............3

1.1.3. Gemcitabine prodrug design, acyl modification at the $4-(N)-$ and 5'$(O)$-positions.

1.2. Application of positron emitting radiotracers for anticancer therapy prognosis.

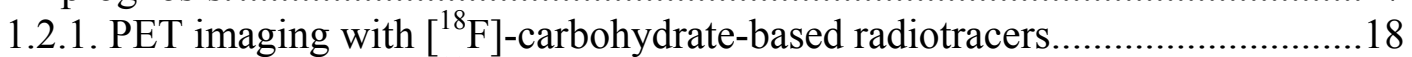

1.2.2. PET imaging with $\left[{ }^{18} \mathrm{~F}\right]$-pyrimidine-based probes ...................................... 19

1.2.2. Anticancer properties of gallium and its application to PET imaging. ..........23

2. RESEARCH OBJECTIVES ......................................................................... 27

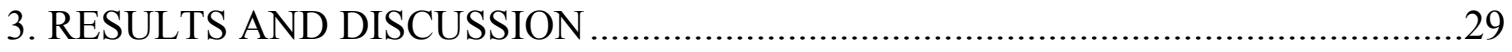

3.1. Design and synthesis of the 4-N-alkanoyl and 4-N-alkyl gemcitabine

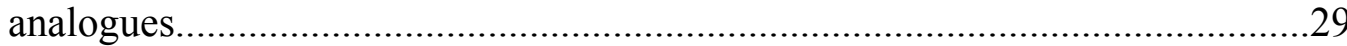

3.1.1. Synthesis of the 4- $N$-alkanoylgemcitabines bearing a terminal olefin............30

3.1.2. Synthesis of fluorinated $4-N$-alkanoylgemcitabines by addition of

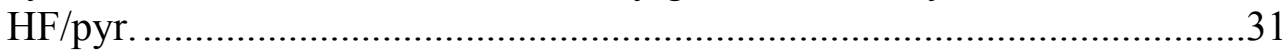

3.1.3. Synthesis of 4- $N$-alkanoylgemcitabine bearing other terminal groups ..........34

3.1.4. Synthesis of $4-N$-alkylgemcitabines bearing a terminal methyl or olefin.

3.1.5. Synthesis of the fluorinated $4-N$-alkylgemcitabine by addition of $\mathrm{HF} / \mathrm{pyr}$.

3.1.6. Synthesis of the $4-N$-alkylgemcitabines bearing other terminal groups.

3.1.7. Fluorination of the $4-N$-alkylgemcitabine with DAST.

3.1.8. Direct conjugation of gemcitabine with bifunctional chelators. ....................46

3.1.9. Attempted synthesis of the 4-N-alkanoylgemcitabine bearing a terminal amine for conjugation to bifunctional chelators.

3.1.10. Synthesis of the 4-N-alkylgemcitabine bearing a terminal amine for conjugation to bifunctional chelators.

3.1.11. Synthesis of aliphatic side chain precursors for the 4-N-alkanoyl and 4- $N$-alkyl gemcitabine analogues.

3.2. Biological evaluation of the $4-N$-modified gemcitabine analogues......................54

3.2.1. Preliminary cytostatic evaluation of $4-\mathrm{N}$-modified gemcitabine

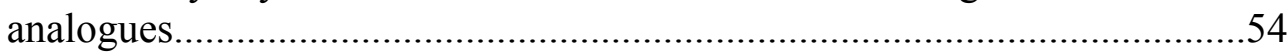

3.2.2. Cytostatic evaluation of the $4-N$-modified gemcitabine analogues. ..............63

3.3. Synthesis and characterization of $\left[{ }^{18} \mathrm{~F}\right]$ - and $\left[{ }^{68} \mathrm{Ga}\right]-4-N$-alkylgemcitabine radioligands. 
3.3.1. $\left[{ }^{18} \mathrm{~F}\right]$-Labeling and evaluation of the $\left[{ }^{18} \mathrm{~F}\right]-4-N$-alkylgemctiabine

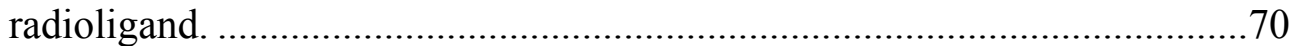

3.3.2. $\left[{ }^{68} \mathrm{Ga}\right]$-Labeling and evaluation of NOTA-4- $N$-alkylgemcitabine

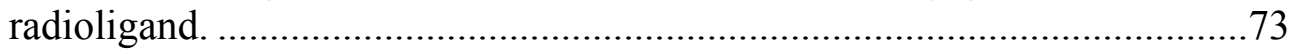

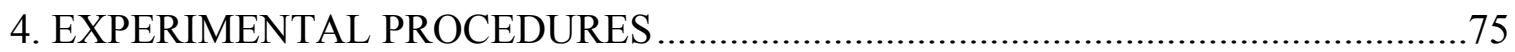

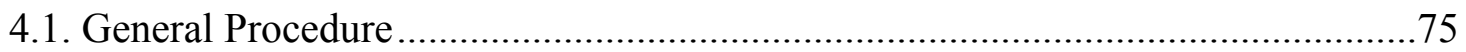

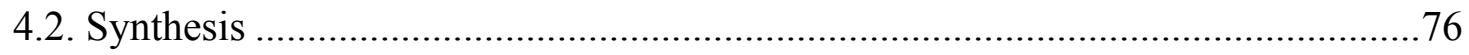

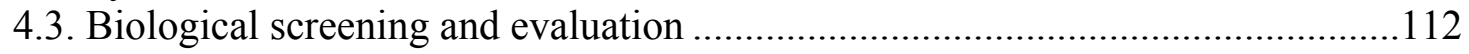

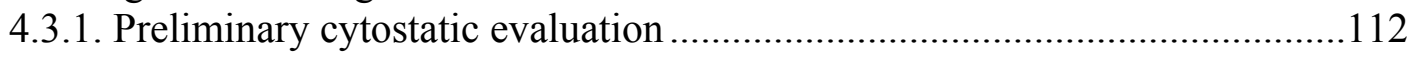

4.3.1.4. Cell cycle analysis by flow cytometry using propidium iodide

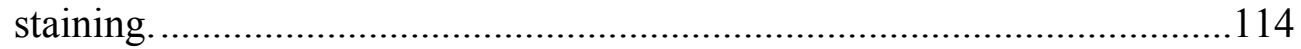

4.3.2. Cytostatic evaluation in Panc-1 cells .........................................................115

4.3.3. In Vitro evaluation in L1210, CEM/0, CEM/dCK-, HeLa and MCF-7

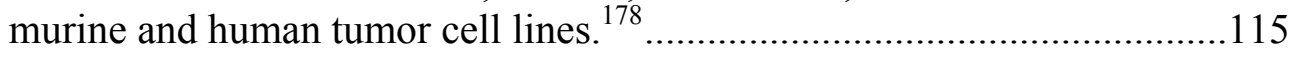

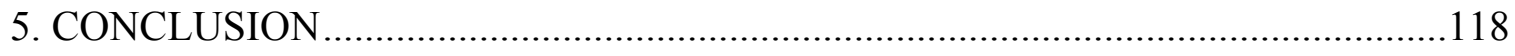

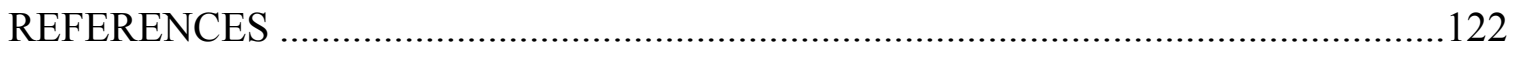

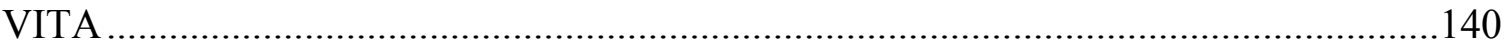




\section{LIST OF TABLES}

TABLE

PAGE

1. FDA approved purine and pyrimidine antimetabolites for treatment of cancer...........2

2. In vitro cytotoxicity of representative $4-N$-modified gemcitabine analogues on ........56

3. Cell cycle analysis of 4-N-modified gemcitabine analogue treated human tumor cell line MCF-7 by flow cytometry....

4. In vitro cytostatic activity of representative 4- $N$-modified gemcitabine analogues on human tumor cell line Panc-1 ...........................................................64

5. In vitro cytotoxicity of representative $4-N$-modified analogues on a panel of murine and human tumor cell lines. .66

6. Labeling values for NOTA-4- $N$-alkylgemcitabine radioligand with ${ }^{68} \mathrm{Ga}$. 74 


\section{LIST OF FIGURES}

FIGURE

PAGE

1. Chemical structures of relevant selected fluorinated nucleoside analogues.

2. Mechanism of action for 5-fluorouracil (5-FU), 2'-deoxy-5-fluorouridine (5$\mathrm{FdU})$ and $\left(N^{4}\right.$-pentyloxycarbonyl-5'-deoxy-5-fluorocytidine (Capecitabine). 7

3. Kaplan-Meier survival curve, gemcitabine vs 5-fluorouracil ................................. 8

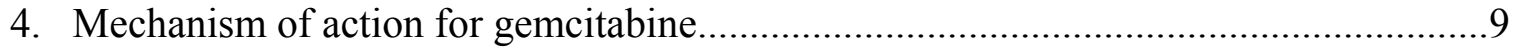

5. Current proposed mechanism for the inactivation of RNR by dFdCDP in the absence and in the presence of reductant.

6. Chemical structures of representative 4-(N)- and 5'-(O)-acylated gemcitabine prodrugs.

7. Chemical structures of gemcitabine-Hoechst conjugate (H-gemcitabine) and gemcitabine-coumarin-biotin conjugate (GMC).

8. Chemical structures of pyrimidine-based NA and FNA radiotracers.

9. Chemical structures of (A) gallium(III) maltolate and (B) tris(8-quinolinolato) gallium(III)

10. Chemical structures of bifunctional chelators for ${ }^{68} \mathrm{Ga}$ labeling...... .26

11. The potential 4- $N$-alkanoyl and 4-N-alkyl gemcitabine radiotracers.

12. HPLC chromatogram of neutralized sample from model fluorination with KF.

13. In vitro cytotoxicity curve of 4-N-alkanoyl and 4-N-alkyl gemcitabine analogues on human tumor cell line MCF-7.

14. Effect of chain length on cytostatic activity of 4- $\mathrm{N}$-alkanoylgemcitabines in MCF-7 cells

15. Effect of varying terminal groups on cytostatic activity of 4-Nalkanoylgemcitabines in MCF-7 cells

16. Cell proliferation time-point measurement study for $25 \mu \mathrm{M}$ treatment of representative 4- $\mathrm{N}$-modified gemcitabine analogues on MCF-7 cell line 
17. Cell proliferation time-point measurement study for $2.5 \mu \mathrm{M}$ treatment of representative 4- $N$-modified gemcitabine analogues on MCF-7 cell line

18. DNA Histograms of MCF-7 cells after $25 \mu \mathrm{M}$ treatment of compound.

19. Time-dependent evaluation of the stability and resistance to deamination for gemcitabine (A), 4-N-alkanoylgemcitabine 21 (B) and 4- $\mathrm{N}$-alkylgemcitabine $31(\mathrm{C})$ in 50\% human serum in PBS

20. Time-dependent evaluation of the stability of 4- $N$-alkanoylgemcitabine 21 and 4- $\mathrm{N}$-alkylgemcitabine $\mathbf{3 1}$ in murine liver extract in PBS

21. Uptake of $\left[{ }^{18} \mathrm{~F}\right]-4-N$-fluoroalkylgemcitabine in $\mathrm{dCK}$ WT and $\mathrm{KO}$ mice. .71

22. Time-dependent study for $\left[{ }^{18} \mathrm{~F}\right]-4-N$-fluoroalkylgemcitabine uptake in dCK WT mice.

23. Time-dependent study of $\left[{ }^{18} \mathrm{~F}\right]-4-N$-fluoroalkylgemcitabine uptake in dCK KO mice.

24. Uptake of $\left[{ }^{18} \mathrm{~F}\right]-4-N$-fluoroalkylgemcitabine in CEM-CCRF tumor bearing mice.

25. TLC for complexation of NOTA-4- $N$-alkylgemcitabine radioligand with ${ }^{68} \mathrm{Ga}$. .74 


\section{LIST OF SCHEMES}

SCHEME

PAGE

1. Synthesis of 2-deoxy-2-[ $\left.{ }^{18} \mathrm{~F}\right]$ fluoro-D-glucose by electrophilic fluorination 18

2. Synthesis of ${ }^{18}$ F-FDG by nucleophilic substitution using KF as a fluoride source

3. Synthesis of $3^{\prime}-$ deoxy-3'-[ $\left.{ }^{18} \mathrm{~F}\right]$-fluorothymidine ([ $\left.\left[{ }^{[18} \mathrm{F}\right]-\mathrm{FLT}\right)$.

4. Synthesis of $2^{\prime}$-deoxy-2'-[ $\left[{ }^{18} \mathrm{~F}\right]$-fluoro-5-methyluridine $\left(\left[{ }^{18} \mathrm{~F}\right]\right.$-FMAU)

5. Synthesis of $2^{\prime}$-deoxy-2'-[ $\left[{ }^{18} \mathrm{~F}\right]$-fluoroarabinocytidine $\left(\left[{ }^{18} \mathrm{~F}\right]\right.$-FAC $)$ 23

6. Synthesis of 4-N-alkanoylgemcitabines using peptide coupling conditions. .30

7. Synthesis of 4- $N$-valproylgemcitabines by peptide coupling conditions. .31

8. Model fluorination of the 4-N-alkanoylgemcitabine olefin with $\mathrm{HF} / \mathrm{pyr}$. .32

9. Carbocation migration during fluorination of a terminal olefin with $\mathrm{HF} / \mathrm{pyr}$.

10. Synthesis of the fluorinated 4- $N$-alkanoylgemcitabine regioisomeric mixture by peptide coupling conditions.

11. Fluorination of olefinic 4-N-valproyl gemcitabine by treatment with $\mathrm{HF} / \mathrm{pyr}$. 33

12. Synthesis of the 4- $N$-alkanoylgemcitabine bearing a terminal fluorine. .34

13. Synthesis of 4- $N$-alkanoylgemcitabine bearing a terminal triazololate. .35

14. Synthesis of 4- $N$-alkanoylgemcitabine bearing a terminal chlorine. .35

15. Synthesis of the 4- $N$-alkanoylgemcitabine bearing a terminal bromine. .36

16. Synthesis of the 4- $N$-bromovalproylgemcitabine bearing a terminal bromine. .37

17. Synthesis of the 4- $N$-alkanoylgemcitabine bearing terminal hydroxyl group.

18. Synthesis of the 4- $N$-alkanoylgemcitabine bearing terminal triflate. .38

19. Fluorination of a 4- $N$-alkanoylgemcitabine with DAST. .39

20. Synthesis of 4- $N$-alkylgemcitabines by nucleophilic aromatic substitution. .40 
21. Fluorination of $4-N$-alkylgemcitabine olefin by addition of $\mathrm{HF} / \mathrm{pyr}$.

22. Synthesis of the $4-N$-alkylgemcitabine bearing a terminal hydroxyl group.

23. Synthesis of 4- $N$-alkylgemcitabine bearing a terminal hydroxyl for the model fluorination with $\mathrm{KF} / \mathrm{K} 222$..

24. Debenzylation of the 4- $N$-alkylgemcitabine by hydrogenation with $\mathrm{H}_{2}$ .44

25. Synthesis of 4- $N$-alkylgemcitabine bearing a terminal mesylate.

26. Fluorination of 4- $N$-alkylgemcitabine with DAST.

27. Model fluorination of $4-N$-alkylgemcitabine with KF/K222 _......................................

28. Synthesis of the 4- $N$-(NODA-GA)gemcitabine conjugate. .......................................47

29. Attempted preparation of the 4- $N$-(SCN-Bn-NOTA)gemcitabine conjugate...............48

30. Synthesis of 4-N-alkanoylgemcitabine with linker bearing a terminal amine.

31. Preparation of 4- $N$-alkylgemcitabine with linker bearing a terminal amine. .50

32. Preparation of the NOTA-4- $N$-alkylgemcitabine conjugate .50

33. Model labeling of NOTA-4- $N$-alkylgemcitabine conjugate with $\mathrm{GaCl}_{3}$. .51

34. Synthesis of diallylacetic acid and 4-Fluoro-2-(2-fluoropropyl)pentanoic acid..........51

35. Synthesis of 5-Bromo-2-propylpentanoyl chloride .................................................52

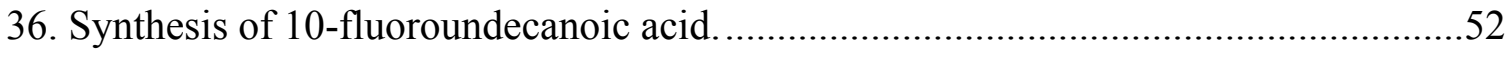

37. Synthesis of 11-fluoroundecanoic acid and 11-bromoundecanoyl chloride................53

38. Synthesis of 11-(benzyloxy)undecan-1-amine. …………………………………......53 


\section{LIST OF ABBREVIATIONS}

\begin{tabular}{ll}
5 -FdU & 5-fluoro-2'-deoxyuridine \\
5 -FU & 5-fluorouracil \\
Abs & absorbance \\
Ar & aromatic (NMR) \\
$\beta$ & beta \\
BFC & bifunctional chelators(s) \\
Bn & benzyl \\
Boc & tert-buyloxycarbonyl \\
br & broad (NMR) \\
BrdU & bromodeoxyuridine \\
$t$-Bu & tert-butyl \\
calcd & calculated (HRMS) \\
CAN & Ammonium cerium (IV) nitrate \\
CDA & cytidine deaminase \\
CDI & 1,1'-Carbonyldiimidazole \\
CHAPS & 3-[(3-Cholamidopropyl)dimethylammonio]-1-propanesulfonate \\
Ci & Curie(s) \\
DA & degrees Celsius \\
$\delta$ & delta \\
d & doublet (NMR) \\
\hline &
\end{tabular}




\begin{tabular}{|c|c|}
\hline $\mathrm{dCK}$ & deoxycytidine kinase \\
\hline DCM & dichloromethane \\
\hline DCTD & deoxycytidylate deaminase \\
\hline $\mathrm{dFdC}$ & 2',2'-difluoro-2'-deoxycytidine \\
\hline $\mathrm{dFdCMP}$ & 2',2'-difluoro-2'-deoxycytidine monophosphate \\
\hline $\mathrm{dFdCDP}$ & 2',2'-difluoro-2'-deoxycytidine diphosphate \\
\hline $\mathrm{dFdCTP}$ & 2',2'-difluoro-2'-deoxycytidine triphosphate \\
\hline DMAP & 4-(N,N-dimethylamino)pyridine \\
\hline DMEM & Dulbecco's modified eagle's medium \\
\hline DMF & $N, N$-dimethylformamide \\
\hline DMSO & dimethylsulfoxide \\
\hline DOTA & $1,4,7,10$ - tetraazacyclododecane-1,4,7,10-tetraacetic acid \\
\hline dUMP & deoxyuridine monophosphate \\
\hline$\varepsilon$ & epsilon \\
\hline EDCI & 1-Ethyl-3-(3-dimethylaminopropyl)carbodiimide \\
\hline ELISA & enzyme-linked immunosorbent assay \\
\hline ESI & electrospray ionization \\
\hline Et & ethyl \\
\hline F-dUDP & 5-fluoro-2'-deoxyuridine diphosphate \\
\hline F-dUTP & 5-fluoro-2'-deoxyuridine triphosphate \\
\hline F-UDP & 5-fluorouridine diphosphate \\
\hline F-UTP & 5-fluorouridine triphosphate \\
\hline FAC & 2'-deoxy-2'-fluoroarabinocytidine \\
\hline
\end{tabular}




$\begin{array}{ll}\text { FDG } & \text { fluorodeoxyglucose } \\ \text { FLT } & \text { 3'-deoxy-3'-fluorothymidine } \\ \text { FMAU } & \text { 2'-deoxy-2'-fluoro-5-methyluridine } \\ \text { FNA } & \text { fluorinated nucleoside analogue(s) } \\ \lambda & \text { gamma } \\ \text { g } & \text { gram(s) } \\ \text { GMC } & \text { gemcitabine-coumarin-biotin conjugate } \\ \text { h } & \text { hour(s) } \\ \text { HDPE } & \text { high-density polyethylene } \\ \text { Hz } & \text { hertz } \\ \text { hCNT } & \text { human concentrative nucleoside transporter } \\ \text { hENT } & \text { human equilibrative nucleoside transporter } \\ \text { HEPES } & \text { N-(2-hydroxyethyl)piperazine- } N \text { '-(2-ethanesulfonic acid) } \\ \text { HOBt } & \text { hydroxybenzotriazole } \\ \text { HPLC } & \text { high performance liquid chromatography } \\ \text { HRMS } & \text { high resolution mass spectroscopy } \\ \text { IC } 50 & \text { half maximal inhibitory concentration } \\ J & \text { coupling constant in Hz (NMR) } \\ \text { K222 } & \text { lithium aluminum hydride } \\ \text { L } & \text { LAH }\end{array}$




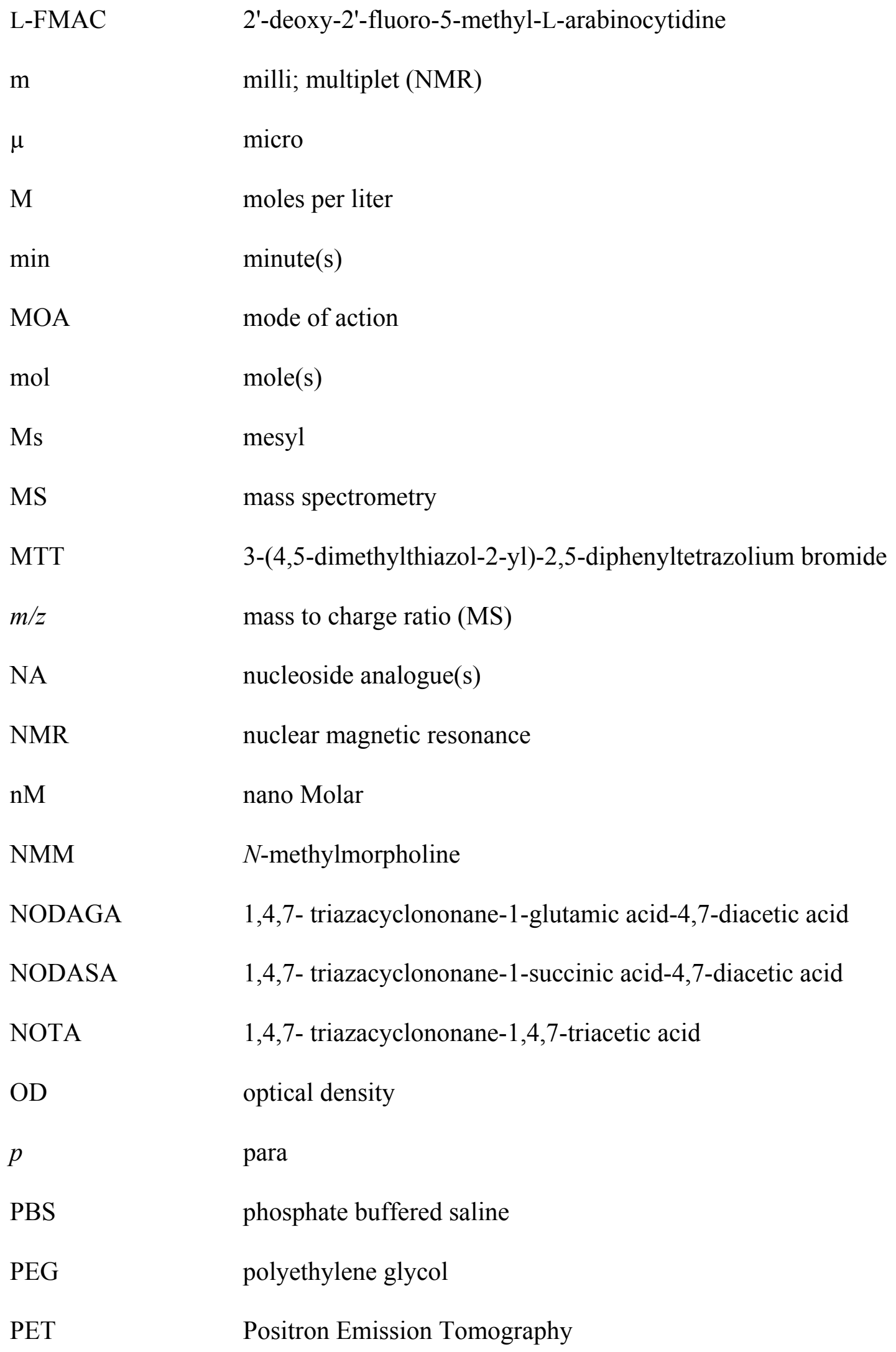




\begin{tabular}{|c|c|}
\hline PI & propidium iodide \\
\hline PTFE & polytetrafluoroethylene \\
\hline pyr & pyridine \\
\hline$\%$ & percentage \\
\hline $\mathrm{q}$ & quartet (NMR) \\
\hline quin & quintet (NMR) \\
\hline $\mathrm{RCY}$ & radiochemical yield \\
\hline RGD & Arg-Gly-Asp \\
\hline RNR & Ribonucleotide reductase \\
\hline $\mathrm{rt}$ & room temperature \\
\hline $\mathrm{s}$ & second(s); singlet (NMR) \\
\hline SCN-Bn-NOTA & $\begin{array}{l}\text { (4-isothiocyanatobenzyl)-1,4,7-triazacyclononane-1,4,7-triacetic } \\
\text { acid }\end{array}$ \\
\hline SqGem & squalenoyl gemcitabine \\
\hline $\mathrm{RP}$ & reverse phase (HPLC) \\
\hline SRB & sulphorhodamine B \\
\hline $\mathrm{t}$ & triplet (NMR) \\
\hline TBA & tetrabutylammonium \\
\hline TBAF & tetra-n-butylammonium fluoride \\
\hline TCA & trichloroacetic acid \\
\hline TEA & triethylamine \\
\hline $\mathrm{TF}$ & tissue factor \\
\hline TFA & trifluoroacetic acid \\
\hline
\end{tabular}




$\begin{array}{ll}\text { THF } & \text { tetrahydrofuran } \\ \text { TK } & \text { thymidine kinase } \\ \text { TLC } & \text { thin layer chromatography } \\ \text { TMS } & \text { trimethylsilyl } \\ \text { tR }_{\text {TRAP }} & \text { retention time (HPLC) } \\ \text { TRA,7-triazacyclononane-1,4,7-tris[methyl(2-carboxyethyl) } \\ \text { Tris } & \text { phosphinic acid } \\ \text { TS } & \text { tris(hydroxymethyl)aminomethane } \\ \text { TTP } & \text { thymidylate synthase } \\ \text { UV } & \text { thymidine triphosphate } \\ \text { VIS } & \text { ultraviolet } \\ \text { WT } & \text { visible } \\ & \text { versus } \\ & \text { wild-type }\end{array}$




\section{INTRODUCTION}

\subsection{Nucleoside analogues and their application as chemotherapeutic agents.}

Cancer is the second leading cause of death in the US, accounting for nearly 1 in 4 deaths. ${ }^{1,2}$ Treatment strategies typically employ surgery, radiation, chemotherapy or some combination thereof. Cancers are characterized by unregulated cell division and growth, resulting in higher metabolic rates in comparison to normal cells. ${ }^{3}$ Nucleotides, and by extension nucleosides, are critical building blocks for DNA and RNA replication and repair processes essential to cellular metabolism. Exploitation of a cancer cell's higher cellular metabolism in comparison to normal cells and the fundamental requirements for cell replication has been a strategic focal point in the development of nucleoside-based chemotherapeutic agents. Although many general topics may apply to both purine- and pyrimidine-based anticancer agents, the following discussion will mainly focus on pyrimidine-derived nucleoside analogues as it pertains to the core of my research.

\subsubsection{Nucleoside analogues for the treatment of cancer.}

Nucleoside analogues (NA) are an important class of antimetabolites used in the treatment of cancer. There are currently over 40 nucleoside drugs approved by the FDA as anticancer and antiretroviral agents. Fourteen of the most important purine- and pyrimidine-based antimetabolites used in the treatment of cancer, accounting for nearly $20 \%$ of all drugs used to treat cancer at the time, were described by Parker in 2009 (Table $1)^{4,5}$ 
Table 1. FDA approved purine and pyrimidine antimetabolites for treatment of cancer.

\begin{tabular}{|ll|}
\hline \multicolumn{1}{|c|}{ Drug } & date approved \\
\hline 6-mercaptopurine & 1953 \\
\hline 5-fluorouracil**(5-FU) & 1962 \\
\hline 6-thioguanine & 1966 \\
\hline arabinofuranosylcytosine (Cytarabine)* & 1969 \\
\hline 5-fluoro-2'-deoxyuridine (Floxuridine)** & 1970 \\
\hline 2'-deoxycoformycin (Pentostatin) & 1991 \\
\hline Arabinofuranosyl-2-fluoroadenine (Fludarabine) & 1991 \\
\hline 2-chloro-2'-deoxyadenosine (Cladribine) & 1992 \\
\hline 2',2'-difluoro-2'-deoxycytidine (Gemcitabine)** & 1996 \\
\hline$N^{4}$-pentyloxycarbonyl-5'-deoxy-5-fluorocytidine (Capecitabine)** & 1998 \\
\hline 5-aza-cytidine (Vidaza)* & 2004 \\
\hline 2'-fluoro-2'-deoxyarabinofuranosyl-2-chloroadenine (Clofarabine) $^{* *}$ & 2004 \\
\hline O'-methylarabinofuranosyl guanine (Nelarabine) & 2005 \\
\hline 5-aza-2'-deoxycytidine (Decitabine)* & 2006 \\
\hline
\end{tabular}

*Denotes pyrimidine NA. **Denotes fluoropyrimidine NAs.

The fundamental uptake and metabolism for most NAs typically parallel the natural physiological nucleosides for which they are modeled after. Moreover, many NAs are similarly hydrophilic and require the aid of specialized membrane-bound transport proteins for entry into cells. ${ }^{5}$ Initial phosphorylation of NAs is facilitated by intracellular kinases and, typically, subsequent phosphorylation events by intracellular kinases lead to generation of active phosphate analogues. ${ }^{6}$ Nucleoside analogues characteristically achieve their cytotoxic activity by incorporation of the active phosphate analogue into DNA of cells actively undergoing replication or repair processes, leading to DNA damage and induction of apoptosis. However, many drugs also have specific target interactions which help explain the diversity of observed activities, with several 
possessing "self-potentiating" modes of action. Therapeutic applications of NAs are generally limited by toxicity of the drug associated with the non-specific activation in proliferating normal, non-cancerous cells. Nucleoside analogues rely on enhanced proliferation rates for their preferential uptake in cancer cells and are known to cause lethal damage in normal cells during prolonged treatments. ${ }^{7}$ Moreover, NAs also suffer from induction of resistance attributed to insufficient intracellular concentrations, inadequate attenuation of deoxynucleotide triphosphate (dNTP) pools, or unreliable induction of apoptosis. ${ }^{6}$ A subtype of NAs that has demonstrated a wide spectrum of biological activity and managed to generate significant attention in the scientific community and carving out its own niche anticancer therapy and diagnosis are fluorinated nucleoside analogues (FNA).

\subsubsection{Anticancer activity of fluorinated pyrimidine nucleoside analogues.}

Introduction of a fluorine group into either the sugar or base components of a nucleoside can considerably alter its biological and therapeutic properties. ${ }^{8}$ As such, substitution of hydrogen atoms or hydroxyl groups for fluorine has become a common practice in the search for and design of chemotherapeutically applicable compounds. ${ }^{8,9} \mathrm{~A}$ fluorine atom is a close steric match for a hydrogen atom, still having sufficient electronegativity to effect electronic changes without causing distortion of conformational geometry. ${ }^{8,9}$ Moreover, fluorine atoms also have a similar polarity in comparison to a hydroxyl group and as such can act as a hydrogen bond acceptor. Since the C-F bond length (1.35尺́) so closely resembles that of the C-O bond length of a

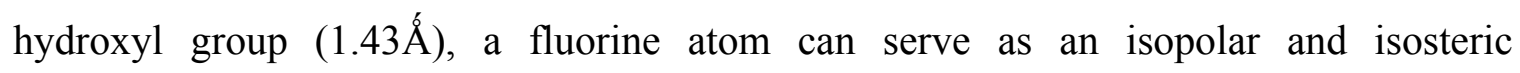
replacement for a hydroxyl group. ${ }^{8,9}$ The C-F bond strength $(116 \mathrm{kcal} / \mathrm{mol})$ is also greater 
than that of a $\mathrm{C}-\mathrm{H}$ bond $(100 \mathrm{kcal} / \mathrm{mol})$, offering a measure of increased biological and chemical stability to the structure. ${ }^{9}$ These are significant characteristics for FNAs as incorporation of a fluorine in the furanosyl moiety restricts the conformation of the sugar ring. ${ }^{8}$ In many cases the stability of a NA or FNA with particular emphasis on the stability of the glycosidic bond, is a key factor for its evaluation as a drug candidate. Incorporation of a fluorine atom at either the 2'- or 3'-position in the sugar moiety of a NA has been reported to increase chemical stability. ${ }^{10}$ Moreover, incorporation of the fluorine at the 2'-position has been shown to suppress in vivo decomposition by stabilization of the anomeric bond effectively increasing metabolic stability. ${ }^{9,11,12}$ The chemical structures of selected FNAs are shown in Figure 1.

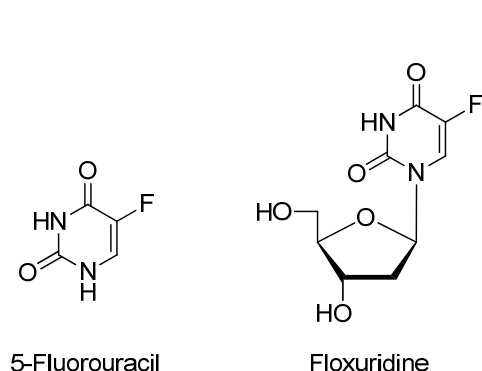

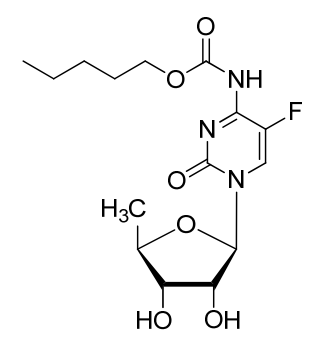

Capecitabine

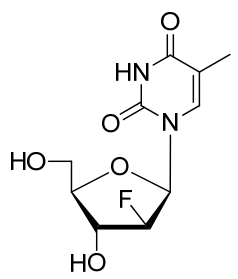

2'-deoxy-2'-fluoro-5-methylarabinouridine

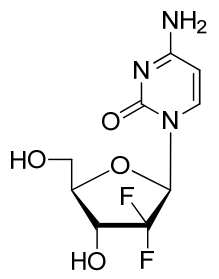

Gemcitabine

Figure 1. Chemical structures of relevant selected fluorinated nucleoside analogues.

A landmark in the development of FNAs, 5-fluorouracil (5-FU, Figure 1) was approved by the FDA in 1962 and is perhaps one of the first examples of a FNA which was designed based on much of the aforementioned characteristics associated with incorporation a fluorine atom. In its conceptualization, Heidelberger et al. also took into consideration available biochemical information, postulating that replacement of the $5-\mathrm{H}$ of the uracil ring with an F-atom would interfere with thymidylate synthases' (TS) ability to methylate deoxyuridine monophosphate (dUMP). ${ }^{13}$ 
The metabolism of 5-FU is well characterized and is shown in Figure 2 as a representative mechanism of action (MOA) for the pyrimidine-based FNAs. ${ }^{5}$ Dihydropyrimidine dehydrogenase is responsible for the intracellular deactivation of 5FU, whereas orotate phosphoribosyl transferase leads to its initial activation by conversion to the 5-FU monophosphate nucleotide F-UMP. ${ }^{5}$ Subsequent phosphorylation events by intracellular kinases give the diphophaste (F-UDP) and the active triphosphate (F-UTP) nucleotides of 5-FU. Incorporation of F-UTP in RNA has been shown to disrupt associated RNA repair processess however is considered a lesser mode of action. ${ }^{5}$ The 5 fluorouridine diphosphate can act as a substrate for ribonucleotide reductase (RNR), the enzyme responsible for the conversion of ribonucleotides to deoxyribonucleotides, to give the 2'-deoxy-5-fluorouridine diphosphate (F-dUDP), which can also undergo phosphorylation to give the 2'-deoxy-5-fluorouridine triphosphate (F-dUTP). The FdUTP is a good substrate for DNA polymerases and is actively incorporated into DNA. The F-dUTP can be removed from the DNA by uracil glycosylase, the enzyme responsible for the uracil excision and repair in DNA. However, accumulation of repeated single strand breaks during excision repair inevitably causes apoptosis. Action by dUTPase on F-dUTP gives the deoxy- monophosphate F-dUMP which potently inhibits TS, as mentioned above, and ultimately reduces intracellular levels of thymidine triphosphate (TTP). The reduced level of TTP available to compete with F-dUTP propagates its incorporation into DNA, removal by uracil glycosylase and triggering of an apoptotic event.

The FNA 2'-deoxy-5-fluorouridine (5-FdU, Figure 1), FDA approved in 1970 and marketed as Floxuridine, mimics the MOA of 5-FU (Figure 2). Following entry into the 
cell, 5-FdU is an efficient substrate for thymidine kinase and is directly converted into FdUMP, which either inhibits thymidylate synthase (decreasing TTP pools) or is phosphorylated further to F-dUTP for incorporation into DNA. The 5-FdU can also participate in the same reaction pathway as 5 -FU after its direct conversion into 5 -FU by thymidine phosphorylase.

The FNA Capecitabine ( $N^{4}$-pentyloxycarbonyl-5'-deoxy-5-fluorocytidine, Figure 1), marketed as $\mathrm{Xeloda}{ }^{\circledR}$, was later developed as an oral prodrug of 5-FU and is used in the treatment of colon and metastatic breast cancers. ${ }^{5}$ First approved by the FDA in 1998, capecitabine undergoes three intracellular transformations for its conversion to 5-FU (Figure 2). Cleavage of the $N^{4}$-pentyloxycarbonyl moiety by carboxylesterases in the liver gives 5'-deoxy-5-fluorodeoxycytidine. Intracellular deamination of 5'-deoxy-5fluorodeoxycytidine by cytidine deaminase (CDA) leads to the uracil derivative 5'-deoxy5-fluorodeoxyuridine. ${ }^{5}$ As is similarly observed for 5-FdU, action by thymidine phosphorylase facilitates the conversion of 5'-deoxy-5-fluorodeoxyuridine into 5-FU. The advantage of using capecitabine instead of 5-FU is the increased bioavailability and also because the overexpression of thymidine phosphorylase in tumor cells offers better selectivity.

Some NAs, and FNAs, have even more complex MOAs or even different spectrums of activities and applications. The FNA 2'-fluoro-2'-deoxy-5-methyluridine (FMAU, Figure 1) was shown to have potent anticancer activity in murine leukemia models however is more commonly associated with its utility as an antiviral agent. ${ }^{8}$ The significance of FMAU and other such FNAs, as it pertains to this discussion, lies in their 
application for diagnosis of cancers and prognosis to chemotherapy, as discussed in later sections (Section 1.1.2.).

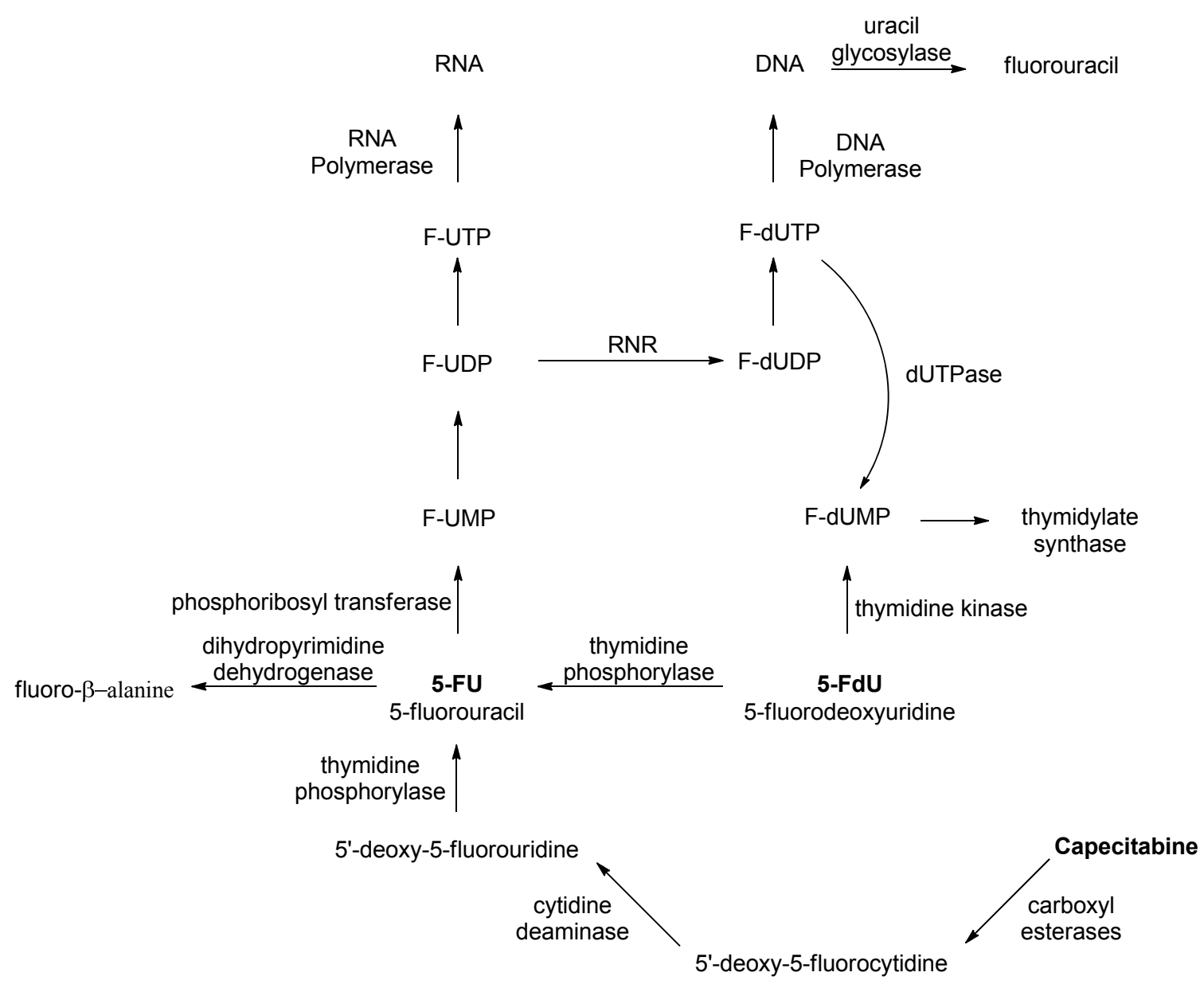

Figure 2. Mechanism of action for 5-fluorouracil (5-FU), 2'-deoxy-5-fluorouridine (5$\mathrm{FdU})$ and $\left(N^{4}\right.$-pentyloxycarbonyl-5'-deoxy-5-fluorocytidine (Capecitabine).

Another milestone in the development of chemotherapeutic FNAs was the making of gemcitabine (2'-deoxy-2',2'-difluorocytidine, Gemzar ${ }^{\circledR}$, 1, Figure 1). First synthesized by Hertel et al. in $1988,{ }^{14}$ gemcitabine received FDA approval in 1996 as first-line therapy in the treatment of pancreatic cancer. Clinical studies revealed that patients treated with gemcitabine vs 5-FU demonstrated significantly improved clinical responses, including decreased rates of mortality and progression of the disease. ${ }^{15,16}$ 


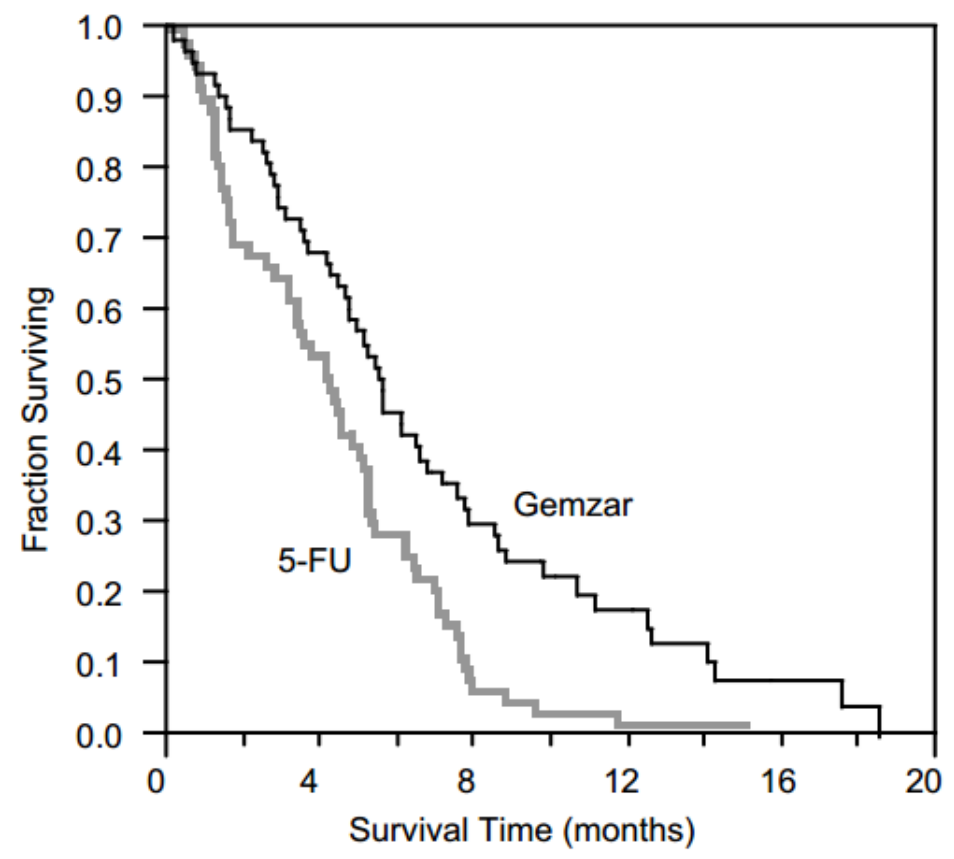

Figure 3. Kaplan-Meier survival curve, gemcitabine vs 5 -fluorouracil. ${ }^{17}$ Gemzar ${ }^{\circledR}$ prescription form of gemcitabine.

Gemcitabine exhibits a wide spectrum of activity and is commonly used in the treatment of solid tumors in various cancers including bladder, breast, pancreatic and non-small cell lung cancer. ${ }^{18-25}$ It is administered intravenously at 1000 to $1250 \mathrm{mg} / \mathrm{m}^{2}$ over 30 minutes weekly, the schedule of administration however varies with cancer type. ${ }^{26,27}$ The metabolism of gemcitabine has been an area of great interest and as such is well characterized, as shown in Figure $4 .^{28}$ 


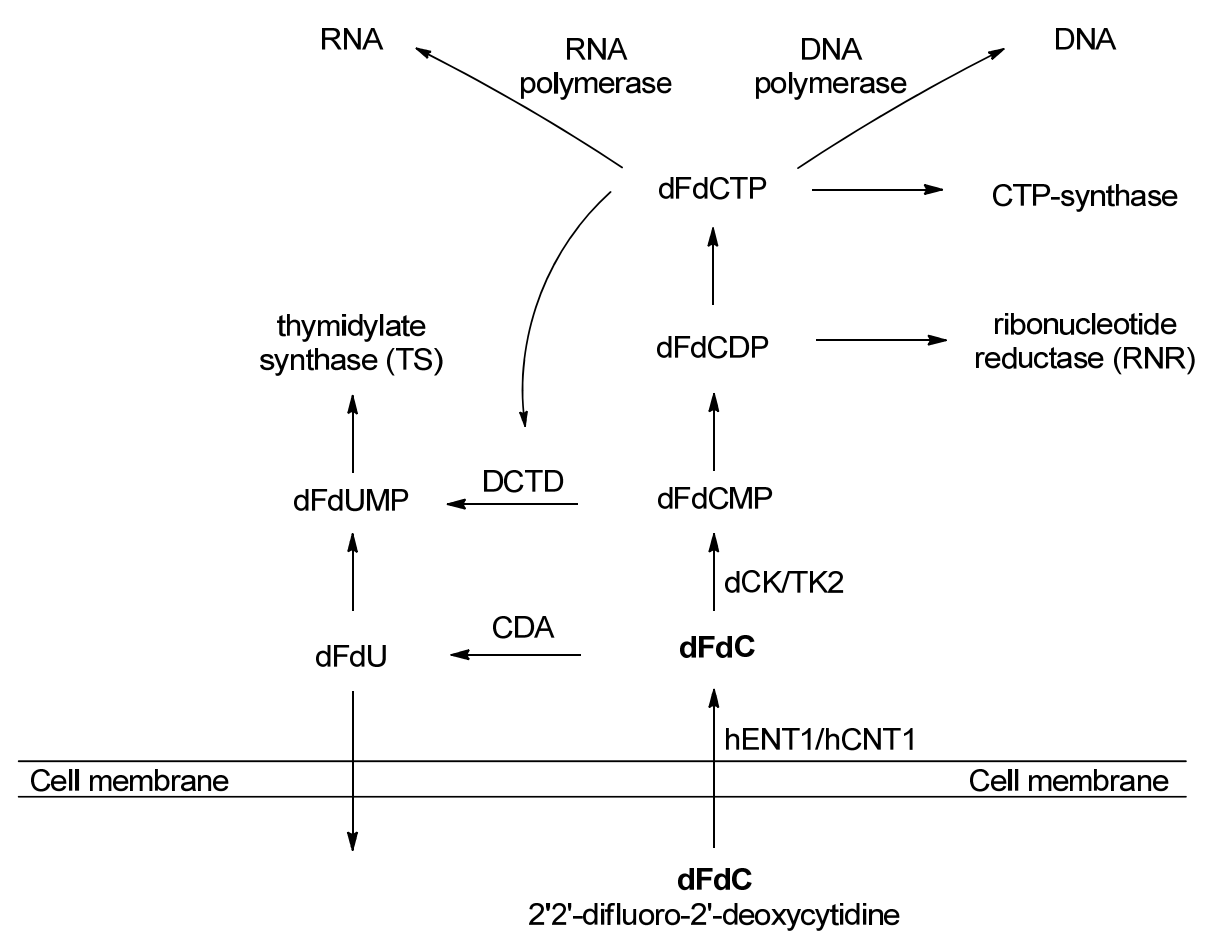

Figure 4. Mechanism of action for gemcitabine. ${ }^{28}$

Gemcitabine is hydrophilic by nature and therefore its cellular uptake requires the aid of membrane bound nucleoside transport proteins. ${ }^{29}$ Cellular uptake of gemcitabine is primarily facilitated by human equilibrative nucleoside transporter-1 (hENT1) and to a lesser extent human concentrative nucleoside transporter-1 (hCNT1) and transporter-2 (hCNT2) ${ }^{30}$ Chemosensitivity to gemcitabine and response to treatment has been shown to correlate to amounts of hENT1 and its level of gene expression. ${ }^{31-34}$ Patients with higher levels of hENT1 had significant increases in survival time in comparison to patients with low levels of hENT1, making hENT1 a prognostic marker for treatment response to gemcitabine. ${ }^{34}$ Following uptake into the cell, gemcitabine is activated via initial phosphorylation by deoxycytidine kinase (dCK), and to a lesser extent thymidine kinase 2 (TK2), to gemcitabine monophosphate (dFdCMP). Subsequent phosphorylations by nucleoside monophosphate and diphosphate kinases give the active di- and tri- 
phosphorylated gemctabines $\mathrm{dFdCDP}$ and $\mathrm{dFdCTP} .^{35,36}$ The pre-treatment level of deoxycytidine kinase, known for its role in the nucleotide salvage pathway, is another marker for prognosis to gemcitabine-based therapy as improved response to treatment correlate to higher than average levels of deoxycytidine kinase. ${ }^{37-40}$ As dFdCTP, gemcitabine behaves similarly to other NAs in its incorporation and inhibition of DNA replication and repair processes which causes apoptosis. ${ }^{32,33}$ Subsequent to its incorporation one additional deoxynucleotide is added after gemcitabine prior to interruption or inhibition of the DNA polymerases, a process described as a "masked chain termination." The "masked chain termination" is suggested to enhance gemcitabines inhibitory activity as exonucleases have been reportedly unable to remove it. ${ }^{41}$ The $\mathrm{dFdCTP}$ has additional minor activity as it can also participate in potentiating its incorporation into RNA by inhibiting CTP-synthase by depleting the competing cytidine triphosphate pools. ${ }^{42,43}$ Moreover, as $\mathrm{dFdCD}(\mathrm{T}) \mathrm{P}$, gemcitabine is a potent stoichiometric inhibitor of both R1 and R2 subunits in RNR, enacting the release of two fluorine atoms and one cytosine base (Figure 5). ${ }^{44-50}$ The current proposed mechanism for inhibition of ribonucleotide reductase (RNR) by $\mathrm{dFdCDP}$ in the presence and absence or reductant as reported by the Stubbe group is shown in Figure $5 .{ }^{50}$ Since RNR is responsible for providing the basic monomeric subunits for DNA replication and repair processes, ${ }^{51,52}$ its inhibition reduces the available pool of nucleosides to able compete with $\mathrm{dFdCTP}$ for incorporation into DNA available. ${ }^{44,46}$ 

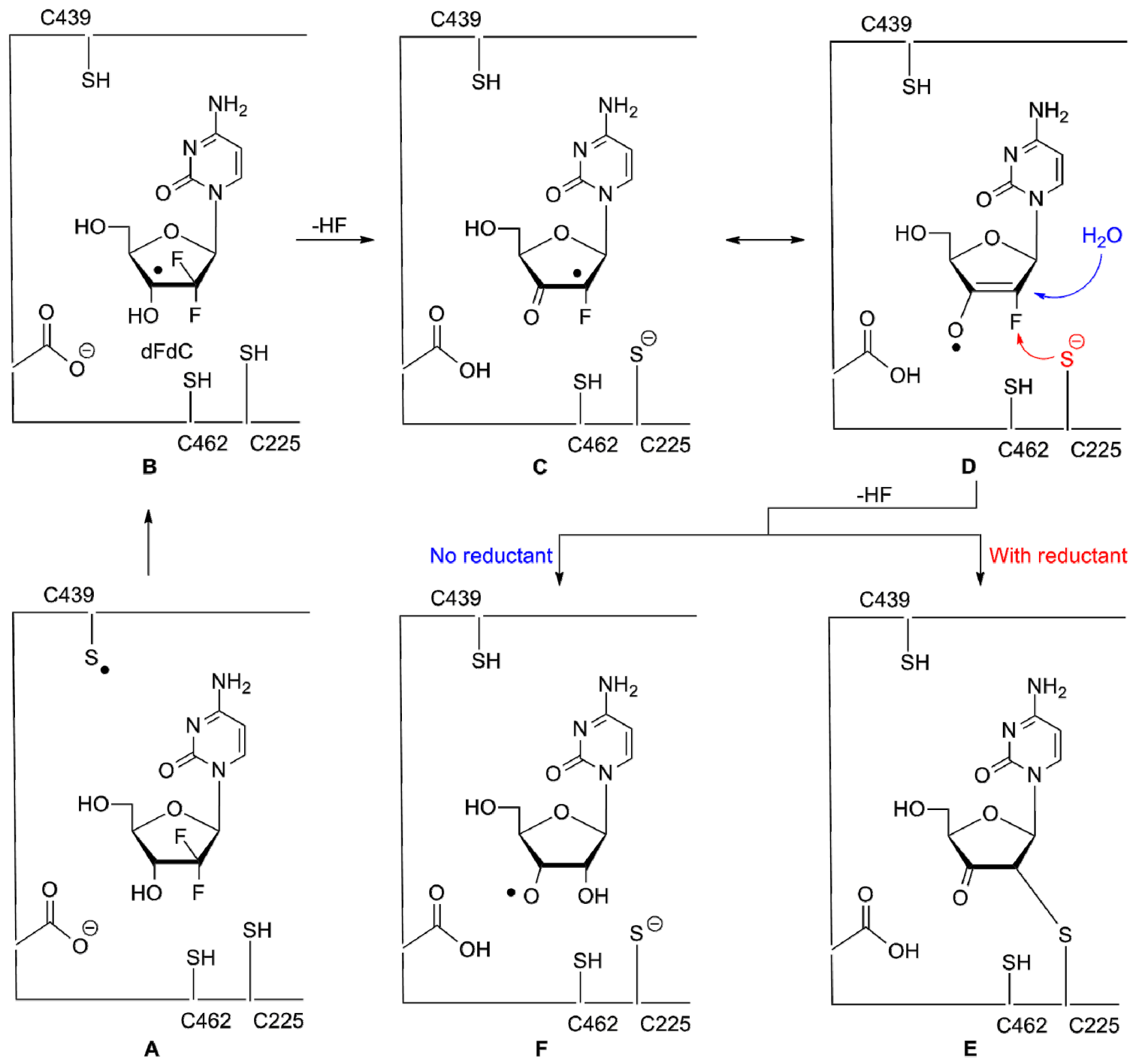

Figure 5. Current proposed mechanism for the inactivation of RNR by dFdCDP in the absence and in the presence of reductant. ${ }^{\mathbf{5 0}}$

Inhibition of DNA (and RNA) replication and repair processes, taken together with modulation of nucleoside pools by inhibition of RNR and CTP synthase, explains the efficacious potency of gemcitabine as a chemotherapeutic agent. However, gemcitabine is therapeutically restricted because of its high toxicity to normal cells. ${ }^{53}$ Moreover, gemcitabine is rapidly inactivated in plasma via enzymatic deamination by cytidine deaminase (CDA) and deoxycytidylate deaminase (DCTD) to corresponding inactive uridine derivatives, which are later excreted in urine. ${ }^{54}$ Over expression in either R1 or 
R2 subunits has been correlated with resistance to gemcitabine treatment in pancreatic cancer both in vitro and in vivo. ${ }^{55,56}$ Clinical studies have shown that prolonged infusion times with lower doses of gemcitabine remains an effective treatment while reducing toxicity to normal cells. ${ }^{57-59}$ As such, various strategies have been developed in an effort to overcome some of the disadvantages associated with gemcitabine while increasing its bioavailability. ${ }^{60}$

\subsubsection{Gemcitabine prodrug design, acyl modification at the 4-(N)- and $5^{\prime}-(O)$ - positions.}

In an effort to increase the bioavailability of gemcitabine, various oral prodrug strategies have been developed featuring lipophilic acyl modifications on either (or both) the exocyclic $4-(N)$ - or $5^{\prime}-(O)$-positions of gemcitabine (Figure 1$) .{ }^{60}$ The acyl prodrug strategy usually exploits some enzymatic or chemical process to release the active metabolite while, in the case of the 4-(N)-modification, first conferring a resistance to deamination.

The synthesis of lipophilic 4-(N)- and 5'-(O)-acyl derivatives of gemcitabine with C18- and/or C20-acyl groups was patented in 1998 (Figure 6). ${ }^{61}$ The 4-(N)- and 5'-(O)acyl derivatives were described as having better cytotoxicity in comparison to the parent gemcitabine, and the hydrolyzable amide or ester modification(s) were suggested to completely alter pharmacokinetics of the gemcitabine by providing a resistance to deamination. Immordino et al. later reported the synthesis of 4-N-acyl gemcitabine derivatives, including 4- $N$-stearoyl gemcitabine, to evaluate the prodrugs for encapsulation in liposomes and other particles. ${ }^{62}$ The $4-\mathrm{N}$-acyl gemcitabine derivatives described therein demonstrated increased anticancer properties to the parent metabolite 
(gemcitabine) and were markedly more resistant to deamination in plasma. ${ }^{62}$ Further work within the Cattel group with these $4-\mathrm{N}$-acyl gemcitabine derivatives demonstrated that the encapsulation efficiency correlated to the lipophilicity afforded by the 4- $N$-acyl modification. ${ }^{63}$ More recent work, carried out in large part in the Cui group, has demonstrated 4-N-strearoylgemcitabine-loaded nanoparticles overcoming gemcitabine resistance in cell lines overexpressing the R1 subunit in RNR. ${ }^{64}$

The Couvreur group later developed the 4- $N$-squalenoylgemcitabine (SqGem, Figure 6) as chemotherapeutic, self-assembling nano-assemblies that would release gemcitabine after localization in the endoplasmic reticulum. ${ }^{65,66}$ The SqGem demonstrated superior anticancer activity to gemcitabine in resistant murine and human leukemia cell lines; the cell lines having been characterized with reduced expression of deoxycytidine kinase and a deficiency in hENT1 respectively. ${ }^{67}$ In similar in vitro studies with pancreatic cell lines and in vivo pancreatic tumor (Panc-1) models, SqGem was shown to overcome the low efficacy of gemcitabine in chemoresistant cancer cells. ${ }^{68}$ Currently, SqGem is undergoing preclinical development for advancement to Phase I clinical trials. ${ }^{68}$

Eli Lilly's orally active 4- $N$-valproylgemcitabine prodrug (LY2334737, Figure 6, 2) was designed to increase the bioavailability of gemcitabine by circumventing deamination during first pass metabolism and facilitating a slow release of the parent drug. ${ }^{69}$ The gemcitabine prodrug LY2334737 was evaluated under conditions similar (and harsher) to those found in the human digestive system and was shown to be highly stable even at a low $\mathrm{pH}=2$. Carboxylesterase 2 was later identified as the enzyme responsible for the systematic release of gemcitabine from LY2334737, ${ }^{70}$ which is now undergoing Phase I clinical trials. ${ }^{71,72}$ 
Recently, synthesis of a 4-( $N)$-PEGgemcitabine conjugate (PEG-gemcitabine, Figure 6) was reported with increased bioavailability of gemcitabine sustained in vivo and showing superior anticancer activity in pancreatic cell lines. ${ }^{73}$ Pasut et al. later modified the PEG-moiety of PEG-gemcitabine by conjugation to a folic acid (folate-PEGgemcitabine, Figure 6) to evaluate the active targeting of cells overexpressing the folic acid receptor. ${ }^{74}$ Therein, release of gemcitabine was shown to proceed in a $\mathrm{pH}$ dependent manner in the folate-PEG-gemcitabine. The folate-PEG-gemcitabine was found to be less cytotoxic than gemcitabine alone in most cases (marginally 2-5 times less potent), however held its activity and displayed an increased affinity towards the cancer cells with increased folic acid receptors when compared to PEG-gemcitabine without the folic acid modification. $^{74}$

As mentioned earlier in the discussion, 4- $(N)$-acyl modification at the 5'-(O)-position was also developed as a means to increase bioavailability of gemcitabine, however without the resistance to deamination afforded by the 4-(N)-acyl modification. Quite probably the most notable of the 5'-(O)-acyl gemcitabine prodrugs is CP-4126, (Figure 6) esterified with an elaidic acid at the 5'-position of gemcitabine's sugar moiety. CP-4126 can be orally administered and has displayed antitumor activity in various xenograft models. ${ }^{75}$ Localization in the cell membrane and superior cytotoxic activity in comparison to gemcitabine in cancer cells deficient in hENT1 suggests an alternative mode of entry for CP-4126. ${ }^{76}$ However, similar activity profiles for CP-4126 and gemcitabine in non-deficient cancer cells suggests the MOA is dCK dependent pending release of gemcitabine from CP-4126 via unidentified esterases. ${ }^{76}$ Although CP-4126 had 
difficulties during Phase I clinical trials, ${ }^{77}$ it is currently undergoing evaluation in Phase II clinical trials for the treatment of metastatic pancreatic cancer. ${ }^{78}$

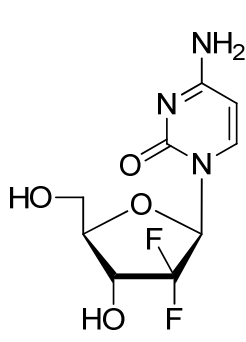

Gemcitabine $\mathrm{dFdC}$

1

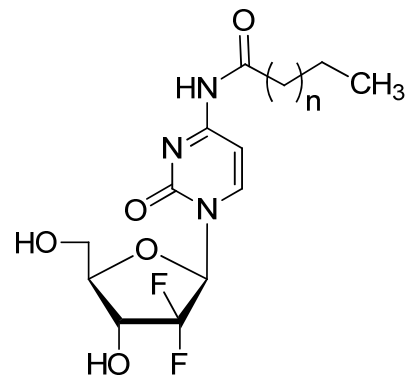

4-(N)-acyl-gemcitabine

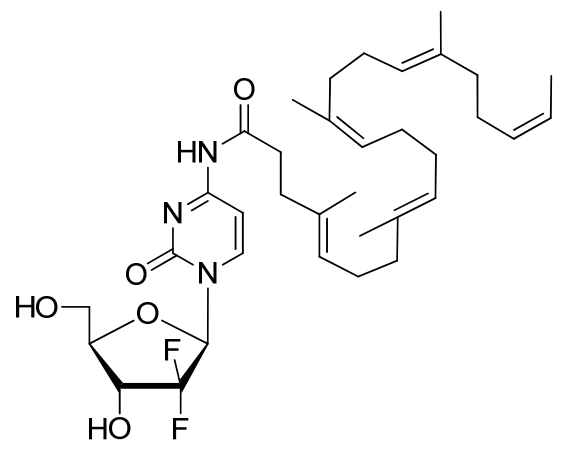

squalenoyl-gemcitabine

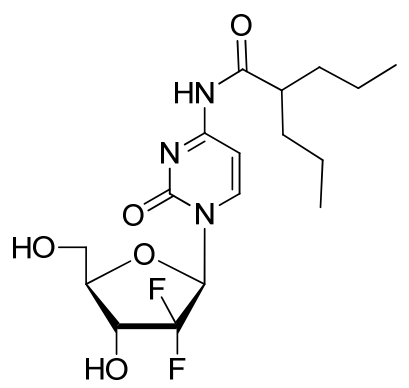

LY2334737

2

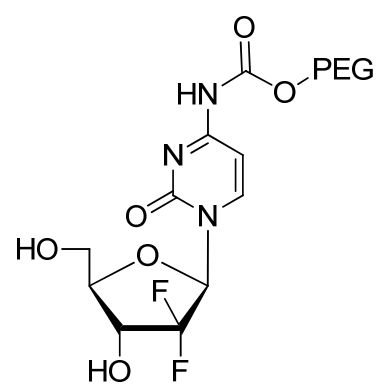

PEG-gemcitabine

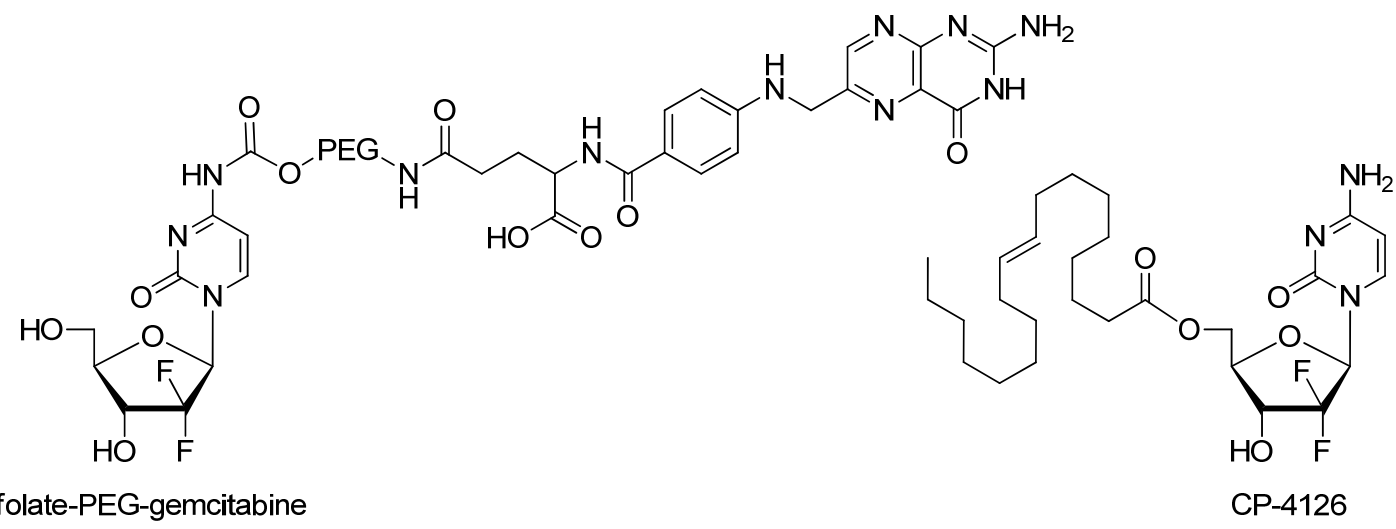

Figure 6. Chemical structures of representative 4-(N)- and 5'-(O)-acylated gemcitabine prodrugs.

Other recent examples of 4-(N)- or 5'-(O)-acylated gemcitabine derivatives are the Hoechst conjugated 4-( $N$ )-acyl derivative H-gemcitabine ${ }^{79}$ (Figure 7), with low toxicity 
but high tumor efficacy, and the 5 '-(O)-acyl gemcitabine prodrugs with coumarin- ${ }^{80}$ (Figure 7, GMC) or boron-dipyrromethene- ${ }^{81}$ (not shown) biotin conjugates. These analogues have been reported for the monitoring of drug delivery at subcellular levels by fluorescence imaging. Although GMC appears more complex in its design, each of these 4-(N)- and 5'-(O)-acylated gemcitabine derivatives were similarly engineered with thiolspecific disulfide bonds, a cancer-targeting unit (Hoechst or Biotin), a fluorescent reporter and a chemotherapeutic agent (gemcitabine) as a theranostic approach to the treatment of cancer.<smiles>CN1CCN(c2ccc3[nH]c(-c4ccc5[nH]c(-c6ccc(OCCOCCOCCNC(=O)CCSSCCC(=O)Nc7ccn(C8OC9(CO)C(F)C(O)C(F)C89F)c(=O)n7)cc6)nc5c4)nc3c2)CC1</smiles>

H-gemcitabine<smiles>COC1C(O)C2OC1C(n1ccc(N)nc1=O)C2(F)F</smiles>

Figure 7. Chemical structures of gemcitabine-Hoechst conjugate (H-gemcitabine) and gemcitabine-coumarin-biotin conjugate (GMC). 


\subsection{Application of positron emitting radiotracers for anticancer therapy prognosis.}

Positron Emission Tomography (PET) scanning is a nuclear medicine imaging technique using radioactive material termed radioligands or radiotracers and relies on the use of radionuclides which decay by positron emission. These radioligands (and PET) have been an invaluable tool for investigating metabolic processes at subcellular levels, allowing for the prognosis and/or monitoring of chemotherapeutic treatment plans. ${ }^{82}$ In recent years, it has become a preferred method when tracking metabolic activities where other specialized probes have been ineffectual. ${ }^{83,84}$

Routine production and clinical use of PET tracers is limited by the availability of the short-lived radionuclides and the developed methods for their preparation. The most common radionuclide for clinical PET imaging is $\left[{ }^{18} \mathrm{~F}\right]$-Fluoride $\left(\mathrm{t}_{1 / 2}=110 \mathrm{~min}\right)$ produced in medical cyclotrons by the proton bombardment $(11-18 \mathrm{MeV})$ of $\left[{ }^{18} \mathrm{O}\right]-$ water. ${ }^{85}$ The $\left[{ }^{18} \mathrm{~F}\right]$-can be isolated for use as either anhydrous $\left[{ }^{18} \mathrm{~F}\right]$-fluoride or as $\left[{ }^{18} \mathrm{~F}\right]$ enriched fluorine gas; the former commonly encounters complications during desolvation, including increase reactivity of the $\left[{ }^{18} \mathrm{~F}\right]$-species. ${ }^{86}$ Although the latter is a common alternative, $\left[{ }^{18} \mathrm{~F}\right]-\mathrm{F}_{2}$ has a lower specific activity and is a highly reactive chemical species making $\left[{ }^{18} \mathrm{~F}\right]$-fluoride the more agreeable choice. Despite the fact that several advancements have been made over the years in the development of specialized and improved fluorination methods, a major drawback to many of the developed fluorination reagents are the high relative abundance of non-radioactive fluorine present during the preparation of the $\left[{ }^{18} \mathrm{~F}\right]$-fluorine source. Moreover, these methods utilize reagents that can be highly hazardous and may react violently with many common materials. ${ }^{86}$ 


\subsubsection{PET imaging with $\left[{ }^{18} \mathrm{~F}\right]$-carbohydrate-based radiotracers.}

Commonly referred to as the "work horse" of PET, 2-deoxy-2- $\left[{ }^{18} \mathrm{~F}\right]$-fluoro- $D$-glucose $\left(\left[{ }^{18} \mathrm{~F}\right]-\mathrm{FDG}\right)$ is the most frequently employed radiopharmaceutical for PET. Originally developed in 1976, $\left[{ }^{18} \mathrm{~F}\right]-\mathrm{FDG}$ was initially designed for mapping the brain glucose metabolism. Since then, $\left[{ }^{18} \mathrm{~F}\right]-\mathrm{FDG}$ has been extensively used for the detection and recurrence of diseases and cancers. ${ }^{87}$ Initial steps for metabolism of FDG, including uptake and phosphorylation by hexokinase, is analogous to D-glucose. ${ }^{88}$ Lacking the 2'hydroxyl group however, FDG is not metabolized further by glucose-phosphateisomerase and accumulates within cells possessing enhanced glucose uptake. ${ }^{88}$ "Metabolic trapping," where $\left[{ }^{18} \mathrm{~F}\right]-\mathrm{FDG}$ is unable to exit the cell, is beneficial when diagnosing, staging or monitoring treatment of a wide variety of cancers. ${ }^{85}$

The first practical synthesis of $\left[{ }^{18} \mathrm{~F}\right]-\mathrm{FDG}$ was described in 1984 and proceeded via electrophilic fluorination with $\left[{ }^{18} \mathrm{~F}\right]-\mathrm{F}_{2}($ Scheme 1$) .{ }^{89,90}$

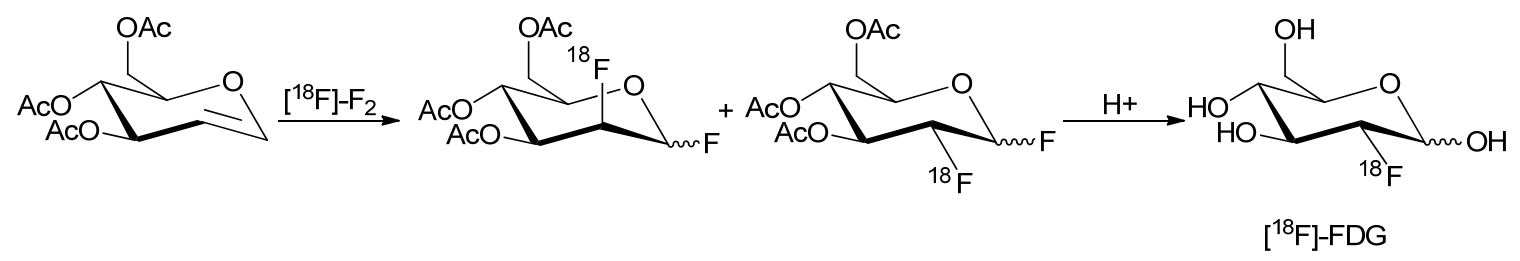

Scheme 1. Synthesis of 2-deoxy-2- $\left[{ }^{18} \mathrm{~F}\right]$ fluoro-D-glucose by electrophilic fluorination. ${ }^{89,90}$

The more current and routinely employed method for the preparation of $\left[{ }^{18} \mathrm{~F}\right]-\mathrm{FDG}$ is performed by automated modules via $\mathrm{S}_{\mathrm{N}} 2$ reaction derived from Hamacher's 1986 breakthrough synthesis, using 1,3,4,6-tetra- $O$-acetyl-2- $O$-trifluoromethanoesulfonyl- $\beta$ - $D$ mannopyranose (mannose triflate) as the precursor and Kryptofix 222 (K222) as a catalyst (Scheme 2). ${ }^{2,91}$ The use of tetrabutylammonium salts (TBA) in place of K222 is 
common, as the latter is toxic and known to cause apnea and convulsions. ${ }^{92}$ The addition of a counter-cation usually necessitates the addition of another anion. ${ }^{85}$ Hydroxide and carbonate anions are employed as they offer little competition in nucleophilic substitution reactions and carbonate anions are the typically the preferred choice, as the hydroxide anion is more likely to facilitate undesired base-catalyzed side reactions. ${ }^{85}$.

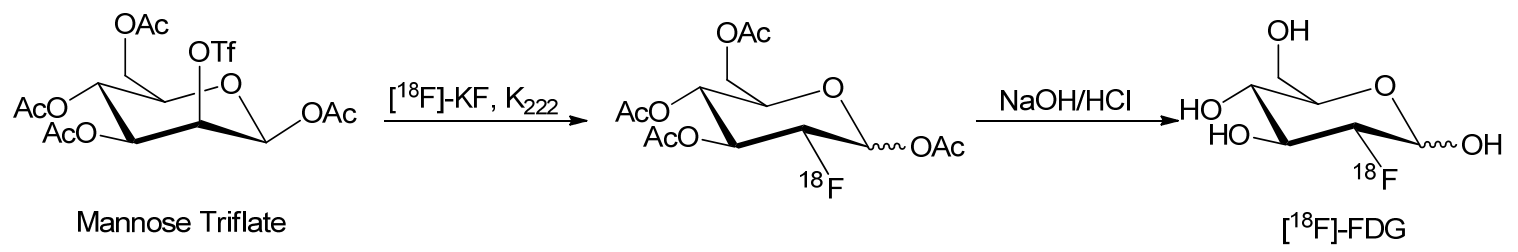

Scheme 2. Synthesis of ${ }^{18}$ F-FDG by nucleophilic substitution using KF as a fluoride source. $^{2}$

The success of $\left[{ }^{18} \mathrm{~F}\right]-\mathrm{FDG}$ as a noninvasive probe for pathophysiological processes led to the synthesis and investigation of a widespread number of $\left[{ }^{18} \mathrm{~F}\right]$-labelled sugars. However, no other such $\left[{ }^{18} \mathrm{~F}\right]$-labelled carbohydrate has of yet exhibited comparable utility.

\subsubsection{PET imaging with $\left[{ }^{18} \mathrm{~F}\right]-$ pyrimidine-based probes}

Several FNAs have been developed as radiotracers and are capable of measuring cell proliferation or some aspect of nucleoside metabolism. These specialized probes are proving invaluable for cancer diagnosis and in evaluating response to chemotherapeutic treatments. Currently, the most applied and well characterized pyrimidine-based FNA PET tracers are 3 '-deoxy-3'-[ $\left[{ }^{18} \mathrm{~F}\right]$-fluorothymidine ([ $\left.\left.{ }^{18} \mathrm{~F}\right]-\mathrm{FLT}\right), 2^{\prime}-\mathrm{deoxy}-2^{\prime}-\left[{ }^{18} \mathrm{~F}\right]$-fluoro-5methyluridine ([ $\left.\left[{ }^{18} \mathrm{~F}\right]-\mathrm{FMAU}\right)$ and $2^{\prime}$-deoxy-2'-[ $\left[{ }^{18} \mathrm{~F}\right]$-fluoroarabinocytidine $\left(\left[{ }^{18} \mathrm{~F}\right]-\mathrm{FAC}\right)$ shown in Figure 8. More recently, the L-isomer radioligands 2 '-deoxy-2'-[ $\left[{ }^{18} \mathrm{~F}\right]$-fluoro-L- 
arabinocytidine (L- $\left.\left[{ }^{18} \mathrm{~F}\right]-\mathrm{FAC}\right)$ and $2^{\prime}-$ deoxy-2'-[ $\left.{ }^{18} \mathrm{~F}\right]$-fluoro-5-methyl-L-arabinocytidine (L- $\left.\left[{ }^{18} \mathrm{~F}\right]-\mathrm{FMAC}\right)$ have also been evaluated for applications to PET (Figure 8).

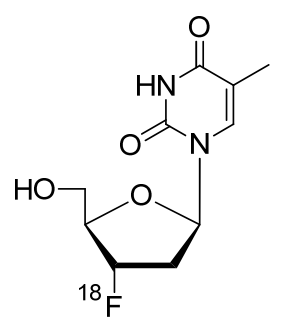

$\left[{ }^{18} \mathrm{~F}\right]-\mathrm{FLT}$

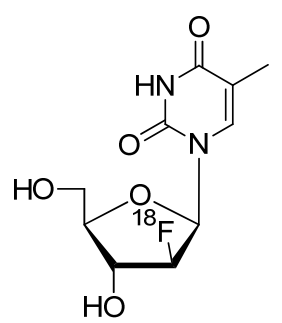

$\left[{ }^{18} \mathrm{~F}\right]-\mathrm{FMAU}$

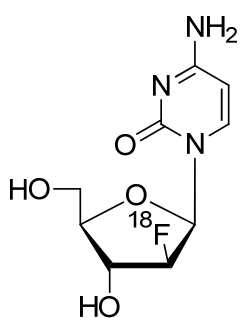

$\left[{ }^{18} \mathrm{~F}\right]$-FAC

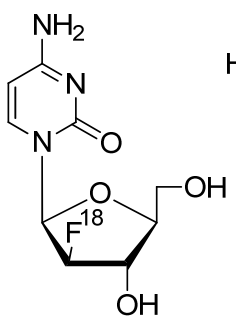

L- $\left[{ }^{18} \mathrm{~F}\right]-\mathrm{FAC}$

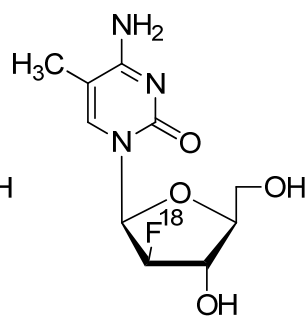

L- $\left[{ }^{18} \mathrm{~F}-\mathrm{FMAC}\right.$

Figure 8. Chemical structures of pyrimidine-based NA and FNA radiotracers.

The most extensively reviewed FNA PET tracer is $\left[{ }^{[18} \mathrm{F}\right]-\mathrm{FLT}$ (Figure 8), which has been evaluated in various types of cancers and is currently part of ongoing clinical trials in a diagnostic capacity. ${ }^{93-96}$ Following uptake into the cell, $\left[{ }^{18} \mathrm{~F}\right]$-FLT is phosphorylated by cytoplasmic enzyme thymidine kinase 1 (TK1). ${ }^{96}$ The monophosphorylated $\left[{ }^{18} \mathrm{~F}\right]$-FLT is trapped inside the cell and is unable to incorporate into DNA as it lacks the 3'-OH group necessary for DNA elongation. ${ }^{97}$ Although not directly correlated to DNA synthesis, $\left[{ }^{18} \mathrm{~F}\right]-\mathrm{FLT}$ phosphorylation has proven to be reliable determinant for approximating metabolic proliferation, ${ }^{96,98-100}$ which is why ${ }^{18}$ F-FLT is an attractive PET tracer for evaluating response to chemotherapeutic treatments. ${ }^{101,102}\left[{ }^{18} \mathrm{~F}\right]$-FLT has been particularly useful in the detection, diagnosis and evaluation of therapies for brain cancers and malignant lymphoma tumors. ${ }^{93-95}$ The first reported synthesis of $\left[{ }^{18} \mathrm{~F}\right]-\mathrm{FLT}$ proceeded via $\mathrm{S}_{\mathrm{N}} 2$ type reaction however suffered from a low radiochemical yield (RCY). ${ }^{103}$ The more conventional synthesis makes use of a protected 3'-nosylate precursor in conjunction with automated radiosynthesizers, employing either HPLC 
system or simple Sep-Pak purification methods, and boasts a far improved RCY of $30 \sim 40 \%$ (Scheme 4). ${ }^{104-107}$
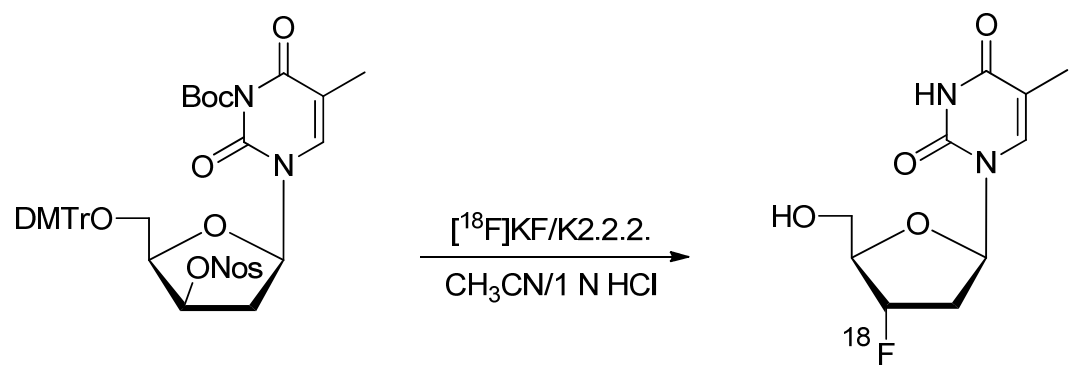

$\left[{ }^{18} \mathrm{~F}\right]-\mathrm{FLT}$

Scheme 3. Synthesis of $3^{\prime}$-deoxy-3'-[ $\left[{ }^{18} \mathrm{~F}\right]$-fluorothymidine $\left(\left[{ }^{[18} \mathrm{F}\right]\right.$-FLT). ${ }^{107}$

Another FNA-based PET tracer used to evaluate the amount of proliferation rates and noninvasive tumor response to therapeutic treatment is $\left[{ }^{18} \mathrm{~F}\right]$-FMAU (Figure 8). Unlike $\left[{ }^{18} \mathrm{~F}\right]-\mathrm{FLT}$, after initial phosphorylation by TK1 and subsequent phosphorylation events, phosphorylated $\left[{ }^{18} \mathrm{~F}\right]-\mathrm{FMAU}$ accumulates in DNA and can be used to directly assess DNA synthesis in proliferating cells. ${ }^{108}$ The rapid clearance and high uptake of $\left[{ }^{18} \mathrm{~F}\right]$ FMAU allows for imaging soon after administering the probe. ${ }^{109}\left[{ }^{18} \mathrm{~F}\right]$-FMAU has also been found to be effective in imaging brain, prostate and lung cancers. ${ }^{108,110}$ The currently employed synthesis of $\left[{ }^{18} \mathrm{~F}\right]$-FMAU proceeds via labeling using $\left[{ }^{18} \mathrm{~F}\right]$-TBAF, one of the more precarious of employed radiofluorination reagents, to give the $\left[{ }^{18} \mathrm{~F}\right]-$ fluorosugar, transformation to bromo- $\left[{ }^{18} \mathrm{~F}\right]$-fluorosugar, silyl-Hilbert-John reaction of bromo- $\left[{ }^{18} \mathrm{~F}\right]$-fluorosugar with persilylated base and subsequent deprotection (Scheme 4). ${ }^{111,112}$ The difficulty with this approach however is the lengthy reaction and purification by HPLC involved in obtaining the active $\beta$-anomer of $\left[{ }^{18} \mathrm{~F}\right]$-FMAU, albeit with a respectable RCY of $20-30 \%$ (Scheme 4$).{ }^{97}$ Alternative synthetic strategies, 
including automated modules, have improved the time frame but suffer from diminished RCY's. ${ }^{113,114}$

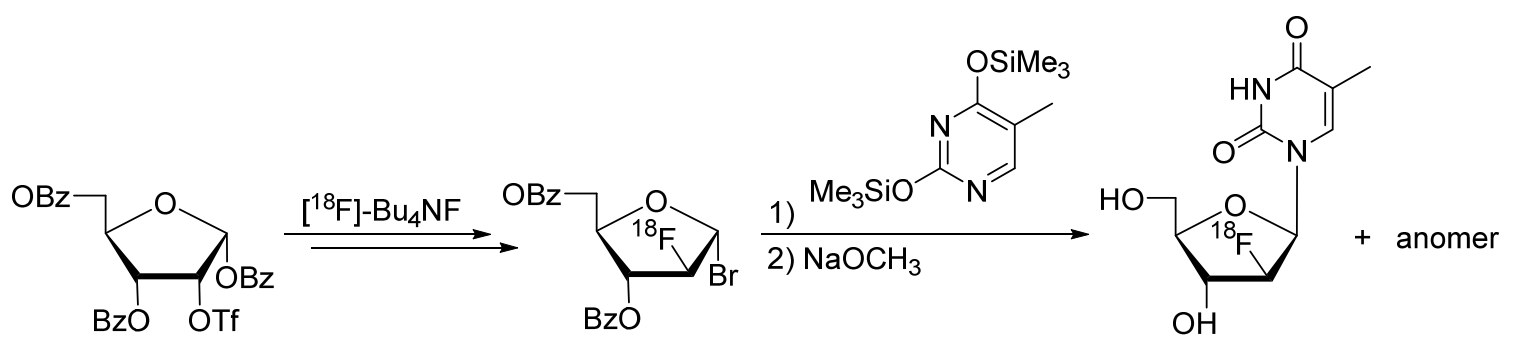

$\left[{ }^{18} \mathrm{~F}\right]-\mathrm{FMAU}$

Scheme 4. Synthesis of 2'-deoxy-2'-[ $\left[{ }^{18} \mathrm{~F}\right]$-fluoro-5-methyluridine ([$\left.{ }^{18} \mathrm{~F}\right]$-FMAU). ${ }^{111}$

The FNA-based PET radiotracer $\left[{ }^{18} \mathrm{~F}\right]-\mathrm{FAC}$ was developed by Radu et al. for the noninvasive evaluation of NA metabolism and treatment efficacy of gemcitabine. ${ }^{39}\left[{ }^{18} \mathrm{~F}\right]-$ FAC has been shown to have a similar substrate affinity for $\mathrm{dCK}$ and CDA comparable to gemcitabine. ${ }^{39}$ Visualization of lymphoid organs with $\left[{ }^{18} \mathrm{~F}\right]$-FAC demonstrated the utility of this probe for evaluating immune response after cancer treatment. ${ }^{39,115}$ Radu et al. demonstrated that tumors with elevated uptake of $\left[{ }^{18} \mathrm{~F}\right]-\mathrm{FAC}$ were also characterized by later reduction in size following treatment with gemcitabine. ${ }^{116}$ Moreover, estimates of $\mathrm{dCK}$ and CDA activities correlated to $\left[{ }^{18} \mathrm{~F}\right]-\mathrm{FAC}$ uptake and were diagnostic for gemcitabine treatment response. ${ }^{38-40,117}$ The Radu group later developed the $\mathrm{dCK}$ specific PET tracers $\left[{ }^{18} \mathrm{~F}\right]-\mathrm{L}-\mathrm{FAC}$ and $\mathrm{L}-{ }^{18} \mathrm{~F}-\mathrm{FMAC}$ with have no substrate affinity to CDA. ${ }^{118}$ Parallel evaluation of the developed L-isomer FNA probes with $\left[{ }^{18} \mathrm{~F}\right]-\mathrm{FAC}$ refined prognosis to gemcitabine treatment response. ${ }^{118}$ Synthesis of $\left[{ }^{18} \mathrm{~F}\right]-\mathrm{FAC}$ also proceeds via silyl-Hilbert-John method employing a $\left[{ }^{18} \mathrm{~F}\right]$-bromosugar and persilyslated base subsequently followed by deprotection (Scheme 5). ${ }^{115}$ 


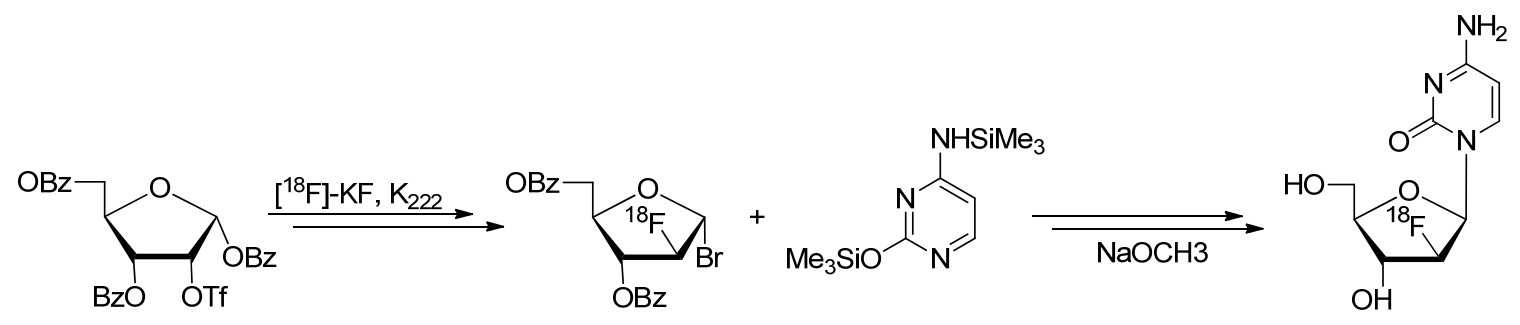

$\left[{ }^{18} \mathrm{~F}\right]-\mathrm{FAC}$

Scheme 5. Synthesis of $2^{\prime}$-deoxy- $2^{\prime}-\left[{ }^{18} \mathrm{~F}\right]$-fluoroarabinocytidine $\left(\left[{ }^{18} \mathrm{~F}\right]-\mathrm{FAC}\right) .{ }^{115}$

\subsubsection{Anticancer properties of gallium and its application to PET imaging.}

Application of 68-gallium $\left({ }^{68} \mathrm{Ga}\right)$ and bifunctional chelators $(\mathrm{BFC})$ for routine use in clinical PET has recently generated substantial interest in the scientific community. ${ }^{119}$ In most cases, $\mathrm{Ga}$ is found in its $3+$ oxidation state and has a chemical behavior that closely resembles that of $\mathrm{Fe}^{3+}$, with comparable electric charge, ion diameter and coordination number (six-coordinated). ${ }^{120}$ As a metal salt, gallium has been reported in having antiproliferative properties in a spectrum of cancer cell types mainly attributed with its ability to mimic $\mathrm{Fe}^{3+} \cdot{ }^{121-123}$ Gallium nitrate (commercially known as Ganite) in particular has proven useful in the treatment of cancer related hypercalcemia. ${ }^{124}$ Gallium metal salts have also demonstrated synergetic effects in combinatorial treatments with other anticancer agents and inhibitors of RNR including gemcitabine. ${ }^{125-128}$ Gallium complexes gallium (III) maltolate and tris(8-quinolinolato)gallium (III) were later developed and shown to increase the bioavailability of gallium, with the majority of gallium delivered this way found to be protein bound (Figure 9). ${ }^{129,130}$ 


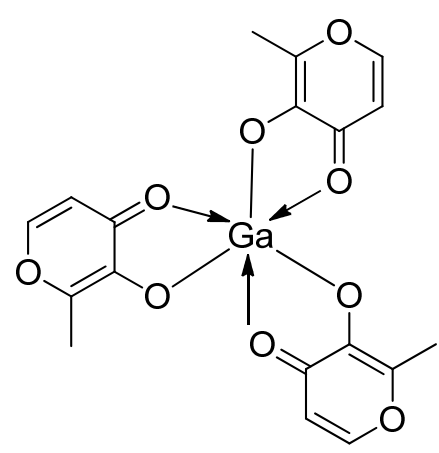

gallium(III) maltolate

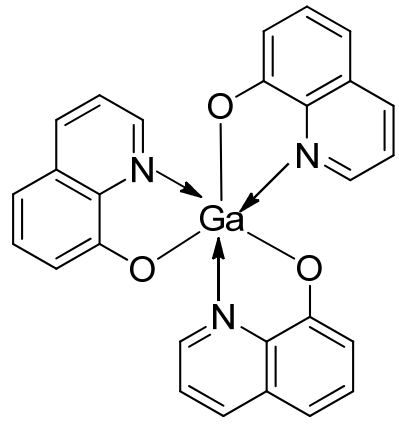

tris(8-quinolinolato)gallium(III)

Figure 9. Chemical structures of (A) gallium(III) maltolate and (B) tris(8-quinolinolato) gallium(III).

However, owing to its high charge density, gallium (III) preferentially reacts with hard donors such as amine or carboxylate atoms. The $\left[{ }^{68} \mathrm{Ga}\right]$ radionuclide is a positron emitting isotope with a short half-life (68 min) and lipophilic nature. Since ${ }^{68} \mathrm{Ga}$ can be obtained from economically available $\left[{ }^{68} \mathrm{Ge}\right] /\left[{ }^{68} \mathrm{Ga}\right]$ generators, ${ }^{131,132}$ and owing to the reported utility for peptide labeling, it is not surprising that extensive efforts were made in developing hard donor, polydentate bifunctional chelators that would allow for better incorporation and delivery of the radionuclide. ${ }^{133}$

Bifuntional chelators possess a reactive functional group which allows for their conjugation to a metabolite of interest as well as a metal binding moiety that follows fundamental coordination chemistry criteria in their design. The metal binding moiety is typically designed for a specific ligand and takes into account matching coordination cavity size to the ionic radius of the radionuclide, having the required number donor groups and providing appropriate donor binding groups. ${ }^{119}$

Among the diverse family of bifunctional chelators, $\operatorname{NODASA}^{134}(1,4,7-$ triazacyclononane-1-succinic acid-4,7-diacetic acid, Figure 10) and NODAGA ${ }^{135}(1,4,7-$ triazacyclononane-1-glutamic acid-4,7-diacetic acid, Figure 10) possess a NOTA (1,4,7- 
triazacyclononane-1,4,7-triacetic acid, Figure 10) complexation site, which has a coordination cavity highly accommodating to Ga(III) (ionic radius of $0.65 \AA$ Á). Although still routinely used for radiolabeling, DOTA $(1,4,7,10$ - tetraazacyclododecane-1,4,7,10tetraacetic acid, Figure 10) is less suited for $\mathrm{Ga}(\mathrm{III})$ complexation, owing to a too large a coordination cavity and an overabundance of donor sites. ${ }^{136-138}$

Radiopharmaceuticals are being dominated by the efficient and target specific labeling of BFC-conjugated peptides which show promising clinical activity. ${ }^{139,140}$ Somatostatin analogues conjugated with DOTA and labeled with ${ }^{68} \mathrm{Ga}$ have been used for the imaging of neuroendocrine tumors and have impacted radiotherapy planning. ${ }^{141}$ DOTA-bombesin conjugates were similarly utilized for diagnosis of prostate cancers having increased expression of the bombesin receptor. The Arg-Gly-Asp (RGD)bombesin derivatives conjugated with ${ }^{68}$ Ga labeled NOTA have shown preferential uptake in PC-3 and MDA-MB-435 tumors and in the pancreas of tumor bearing mice. ${ }^{142}$ The reported RGD-NOTA conjugates have also been advocated for the imaging of angiogenesis by targeting the $\alpha_{v} \beta_{3}$ intergrin receptor. ${ }^{143,144}$ More recently, a TRAP $(1,4,7-$ triazacyclononane-1,4,7-tris[methyl(2-carboxyethyl)phosphinic acid)])-based $\quad$ RGD conjugate was reported having $10-20$ times higher labeling specificity for ${ }^{68} \mathrm{Ga}$ than the NOTA- and DOTA-peptides. ${ }^{145}$ The SCN-Bn-NOTA [(4-isothiocyanatobenzyl)-1,4,7triazacyclononane-1,4,7-triacetic acid, Figure 10] derivative ALT-836, with anti-human tissue factor (TF) monoclonal antibody, demonstrated uptake in BXPC-3 tumors (pancreatic cancer cells overexpressing TF) and has been suggest for advancement to Phase I clinical trials as a combination therapy with gemcitabine. ${ }^{146}$ 


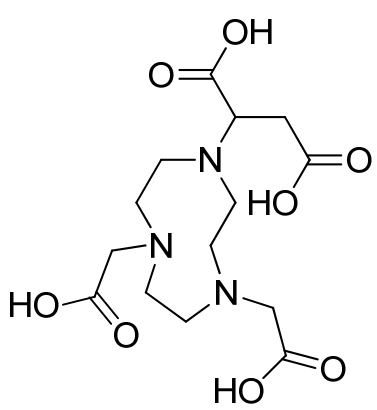

NODASA

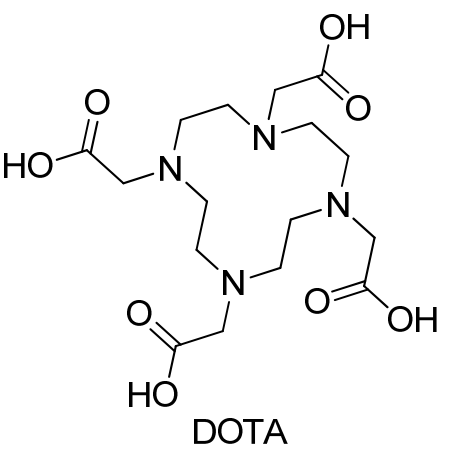

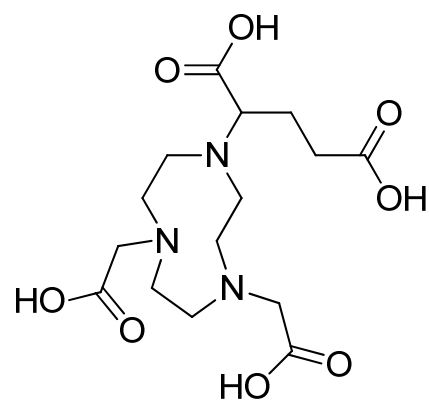

NODAGA

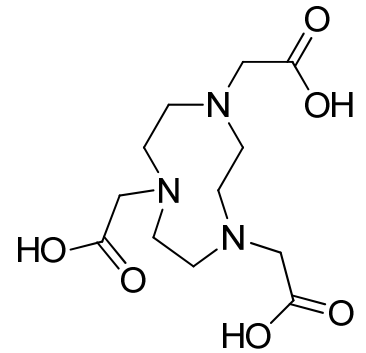

NOTA

Figure 10. Chemical structures of bifunctional chelators for ${ }^{68} \mathrm{Ga}$ labeling. 


\section{RESEARCH OBJECTIVES}

The overall aim of the present dissertation is the design, synthesis and biological evaluation of 4- $N$-alkanoyl (e.g., 9) and 4- $N$-alkyl (e.g., 39 and 48) gemcitabine analogues as theranostic agents, with potential application towards positron emission tomography imaging (Figure 11).
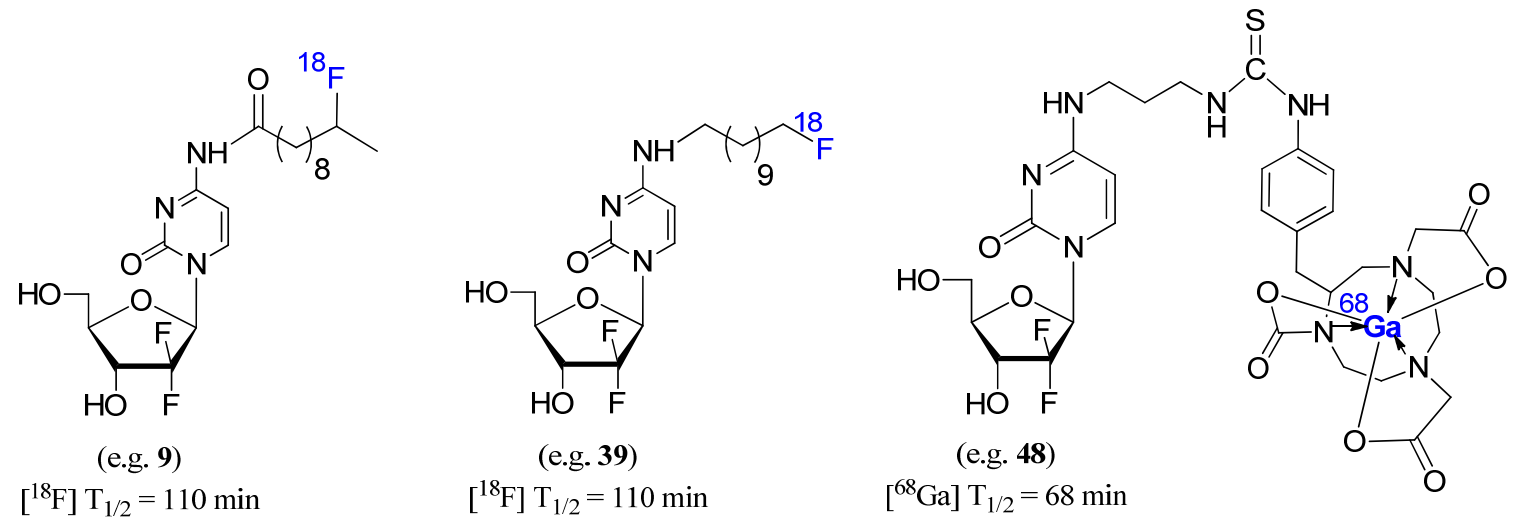

Figure 11. The potential 4- $\mathrm{N}$-alkanoyl and $4-\mathrm{N}$-alkyl gemcitabine radiotracers.

The initial target of my dissertation was the synthesis of $4-N$-modified gemcitabine analogues featuring either long alkanoyl or alkyl chains with varying terminal functionalities (olefin, bromine or hydroxyl groups). The varying terminal groups were intended for further chemical modification compatible with radiosynthetic protocols. Modification of the 4-(N)-position of the gemcitabine's exocyclic amine to an amide functionality is known to confer a resistance to intracellular deamination by CDA. ${ }^{69,147}$ Additionally, the 4-(N)-amide modification of gemcitabine is reported to undergo cleavage/hydrolysis and facilitate a slow release of the parent drug, improving its pharmacokinetics by increasing its bioavailability. ${ }^{69}$ The $4-N$-alkylation of gemcitabine is largely underrepresented in literature and to the best of my knowledge has not been studied in depth with examples thereof limited to short modifications. ${ }^{148}$ In contrast to 
their acyl counterparts, the 4- $N$-alkylgemcitabines are enzymatically resistant to cleavage at the 4- $(N)$ position and will prove diagnostic for the effect the modification itself has on the activity and metabolism for these analogues. Moreover, the chemical stability of the 4- $N$-alkyl linkage makes these analogues uniquely suited for further chemical modification under conditions in which the 4- $N$-alkanoyl linkage would be cleaved.

The next objective was the evaluation and comparison of the cytostatic properties and mechanism of action for the synthesized 4- $N$-alkanoyl and the 4- $N$-alkyl gemcitabine analogues. Since it was unknown whether the $4-N$-alkyl modification also facilitates a slow release of the parent drug, stabilities of the 4- $\mathrm{N}$-alkylgemcitabines needed to be evaluated in parallel with the 4- $N$-alkanoylgemcitabines.

The final objective was to develop a synthetic method which would allow for the convenient preparation of the ${ }^{18} \mathrm{~F}$ or ${ }^{68} \mathrm{Ga}$ modified gemcitabine-based radioligands suitable for PET-based imaging. Since the modifications were envisioned to provide a site for incorporation of a radionuclide, the approach will take into consideration the associated short half-lives of the ${ }^{18} \mathrm{~F}$ and ${ }^{68} \mathrm{Ga}$ isotopes. 


\section{RESULTS AND DISCUSSION}

\subsection{Design and synthesis of the $4-N$-alkanoyl and $4-N$-alkyl gemcitabine analogues.}

The initial targets of this dissertation were the synthesis of $4-\mathrm{N}$-modified gemcitabine analogues suitable for further chemical modification. The 4-N-alkanoyl and 4-N-alkyl modification of nucleosides containing cytosine have been reported to confer resistance to intracellular deamination by $\mathrm{CDA},{ }^{62,147}$ while the long aliphatic chain should affect pharmacodynamics and cellular uptake of the drug. The lipophilic 4- $\mathrm{N}-$ alkanoylgemcitabines 3-6 most closely resemble the 4- $N$-stearoylgemcitabine ${ }^{45}$ (Figure 6) and $4-N$-squalenoylgemcitabine ${ }^{65}$ (Figure 6) previously described in literature by the Cattel and Couvreur groups, respectively. Whereas the 4- $N$-valproylgemcitabines 7 and 8 were prepared in an effort to draw a comparison between our 4- $\mathrm{N}$-modified gemcitabine analogues and Eli Lilly's branched 4-N-valproylgemcitabine oral prodrug (2, LY2334737). ${ }^{149}$ The $4-N$-alkylgemcitabine derivatives complement their $4-N$ alkanoylgemcitabines counterparts and offer a point of contrast for the evaluation of the 4- $(N)$ amide linkage. The $2^{\text {nd }}$ generation $4-N$-alkylgemcitabine with short chain linker was developed for conjugation to a bifunctional chelator (SCN-Bn-NOTA).

The varying terminal moieties of the featured aliphatic chains provide a site for modification and incorporation of a radioligand for combinatorial cancer treatment and imaging by PET. Analogues bearing a terminal double bond (4-6, 8 and 26) could serve as a substrate for introduction of an ${ }^{18} \mathrm{~F}$ radionuclide by addition of radiolabeled $\left[{ }^{18} \mathrm{~F}\right]$ $\mathrm{HF} /$ pyridine (Olah's reagent). ${ }^{150}$ On the other hand, analogues containing a terminal leaving group $(\mathbf{1 7}, \mathbf{1 9}, 22$ and 37$)$ could serve as precursors for nucleophilic substitution with $\left[{ }^{18} \mathrm{~F}\right]-\mathrm{KF} .{ }^{151,152}$ The 4-N-alkanoylgemcitabine $\mathbf{4 1}$ and the 4-N-alkylgemcitabine $\mathbf{4 7}$, 
conjugated with NODA and NOTA bifunctional chelators respectively, could serve as substrates for labeling with $\left[{ }^{68} \mathrm{Ga}\right]$.

\subsubsection{Synthesis of the 4- $\mathrm{N}$-alkanoylgemcitabines bearing a terminal olefin.}

Several of the 4- $N$-alkanoylgemcitabine derivatives were prepared employing coupling conditions commonly used in peptide synthesis, proceeding via carbodiimidemediated activation of corresponding long-chain acid derivatives with hydroxybenzotriazole (HOBt). ${ }^{149,153}$ Although alternative acylation methods exist, I found that condensation of gemcitabine $\mathbf{1}$ with commercially available undecanoic acid, or it's terminally unsaturated counterparts of varying chain lengths (8-nonenoic acid, 10undecenoic acid, and 12-tridecenoic acid) in the presence of 1.3 equivalents of EDCI [N(3-dimethylaminopropyl)- $N$ '-ethyl-carbodiimide], 1.1 equivalents $\mathrm{HOBt}$ (1hydroxybenzotriazole) and 1.1 equivalents NMM (N-methylmorpholine) gave the 4- $\mathrm{N}$ alkanoylgemcitabines 3-6 in respective yields of 50\%, 45\%, 66\% and 44\% (Scheme 6).
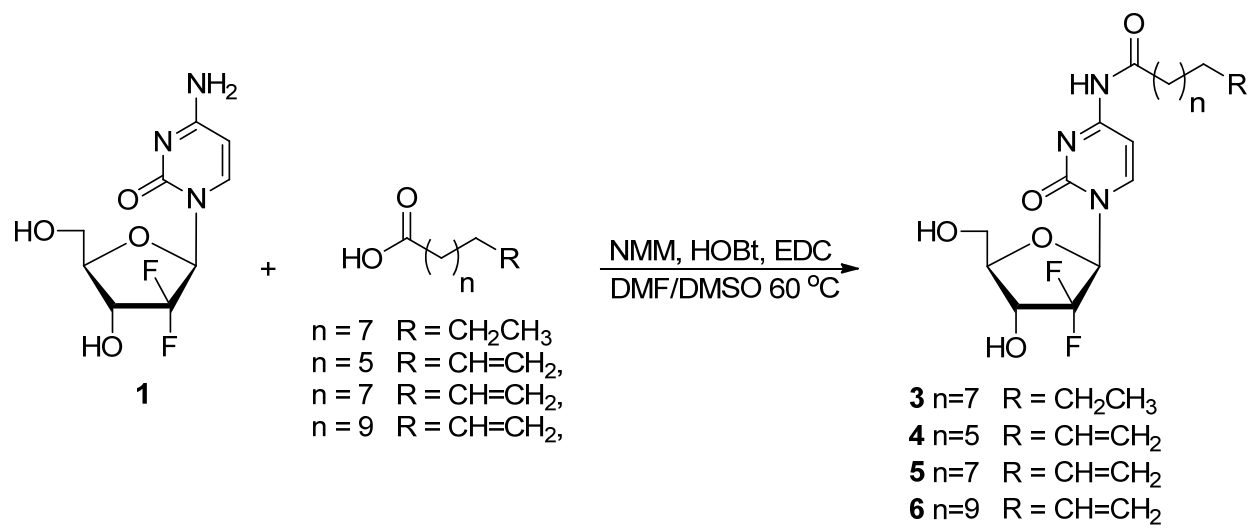

Scheme 6. Synthesis of 4- $N$-alkanoylgemcitabines using peptide coupling conditions.

The branched $4-N$-valproylgemcitabines $7^{149}$ and olefin $\mathbf{8}$ were similarly prepared by condensation of $\mathbf{1}$ with commercially available valproic acid or di-allylacetic acid (51, see section 3.1.11.2., respectively, using peptide coupling conditions (Scheme 7). 

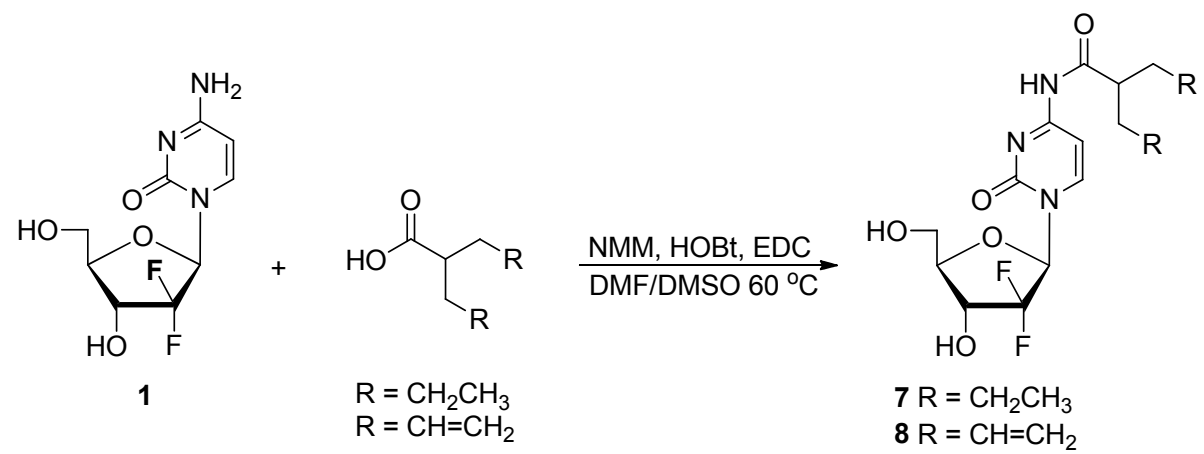

Scheme 7. Synthesis of 4- $N$-valproylgemcitabines by peptide coupling conditions.

\subsubsection{Synthesis of fluorinated 4- $\mathrm{N}$-alkanoylgemcitabines by addition of $\mathrm{HF} / \mathrm{pyr}$.}

The parallel, underlying goal for all the synthesized analogues is the eventual incorporation of a radionuclide for concurrent cancer treatment and PET-based imaging. Haufe et al. recently reported a process for the radiofluorination of alkyl aryl thioethers with $\left[{ }^{18} \mathrm{~F}\right]-\mathrm{HF} /$ pyridine. ${ }^{150,154}$ The work reported by the Haufe group led to the initial concept of an olefin bearing 4- $N$-alkanoylgemcitabine derivative, e.g., analogues 4-6 and 8, and introduction an ${ }^{18} \mathrm{~F}$-radioisotope via electrophilic addition to said terminal double bond. A model study was conducted using regular Olah's Reagent (70\% HF/pyridine) not only to verify the process but also to provide samples to determine cytotoxic efficacy of the proposed fluorination products. Thus, treatment of $\mathbf{5}$ with $\mathrm{HF} /$ pyridine in a chilled HDPE vessel at $0^{\circ} \mathrm{C}$ yielded a regioisomeric mixture of 4- $N$-fluoroalkanoyl derivatives 911 with an isomeric ratio 75:20:5 (91\%, Scheme 8); ${ }^{19} \mathrm{~F}$ NMR was diagnostic for the regioisomeric composition $[\delta-179.79(\mathrm{~m}, 0.05 \mathrm{~F}),-178.83(\mathrm{~m}, 0.20 \mathrm{~F})$ and $-170.27(\mathrm{~m}$, $0.75 \mathrm{~F})]$. Generation of the regioisomeric mixture, which does not include an 11-fluoro anti-Markovnikov product, can be attributed to migration of the carbocation along the chain via a proton 1,2-migration as has been observed before ${ }^{155}$ (Scheme 9). 


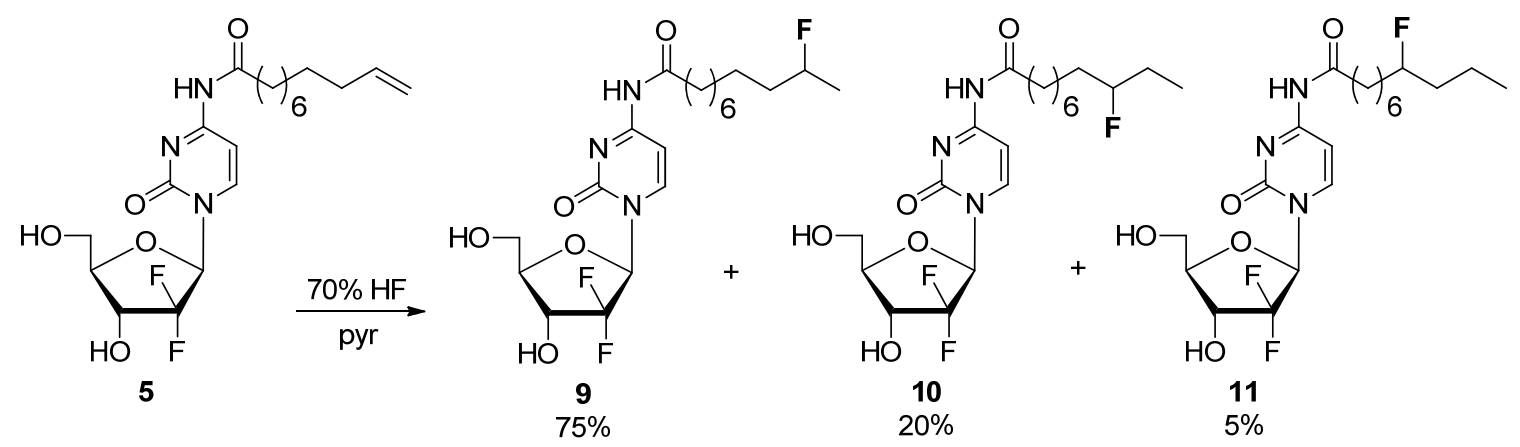

Scheme 8. Model fluorination of the 4-N-alkanoylgemcitabine olefin with HF/pyr.
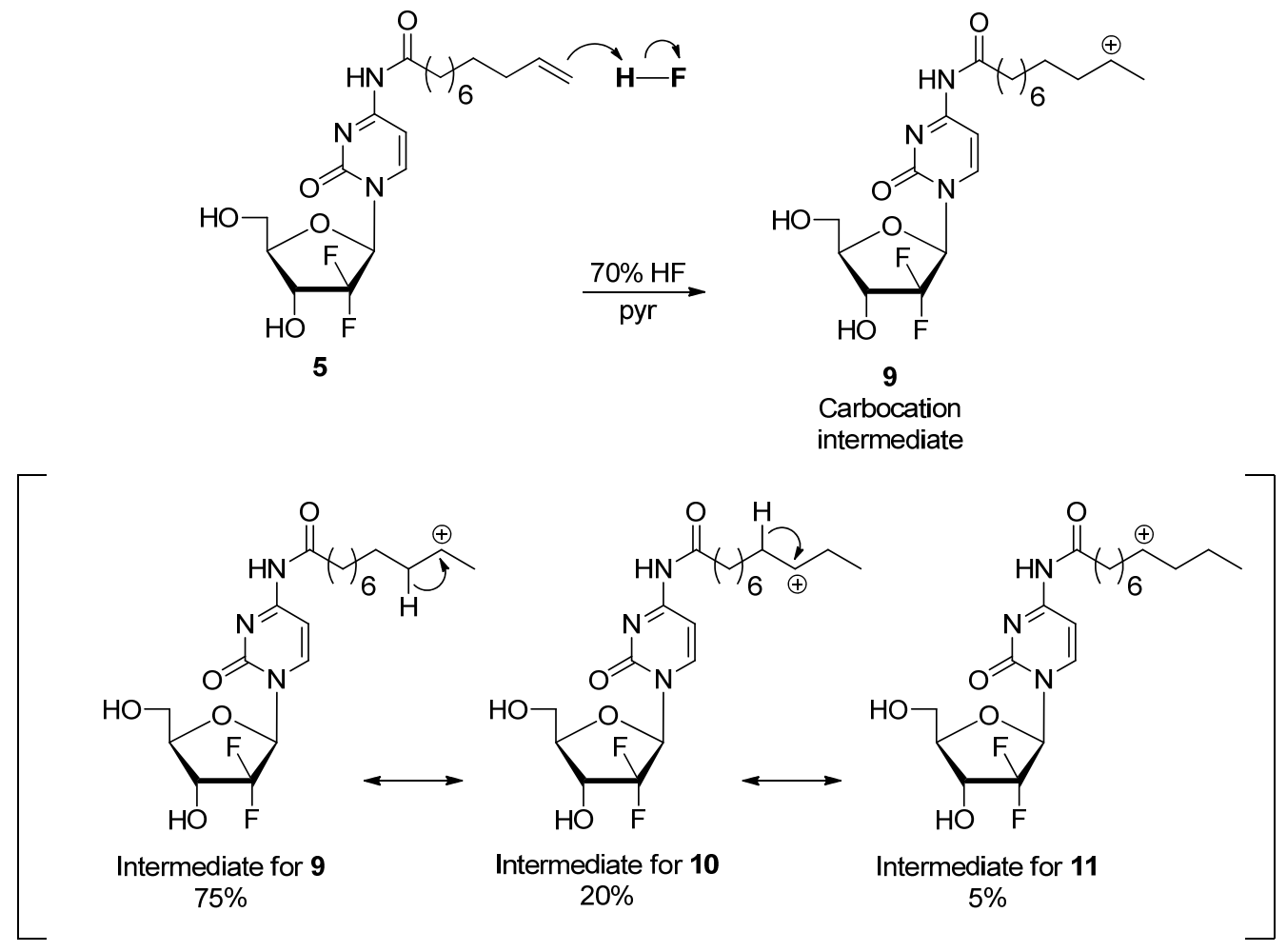

Scheme 9. Carbocation migration during fluorination of a terminal olefin with $\mathrm{HF} / \mathrm{pyr}$.

Alternatively, the condensation of $\mathbf{1}$ with 10-fluoroundecanoic acid [57 (prepared as a regioisomeric mixture containing 10-fluoro-, 9-fluoro- and 8-fluoroundecanoic acids (75:20:5 for 57:58:59)), see section 3.1.11.2] employing peptide coupling conditions similarly afforded a regioisomeric mixture of 4- $N$-fluoroalkanoyl analogues 9-11 with an isomeric ratio 75:20:5 (Scheme 10). 


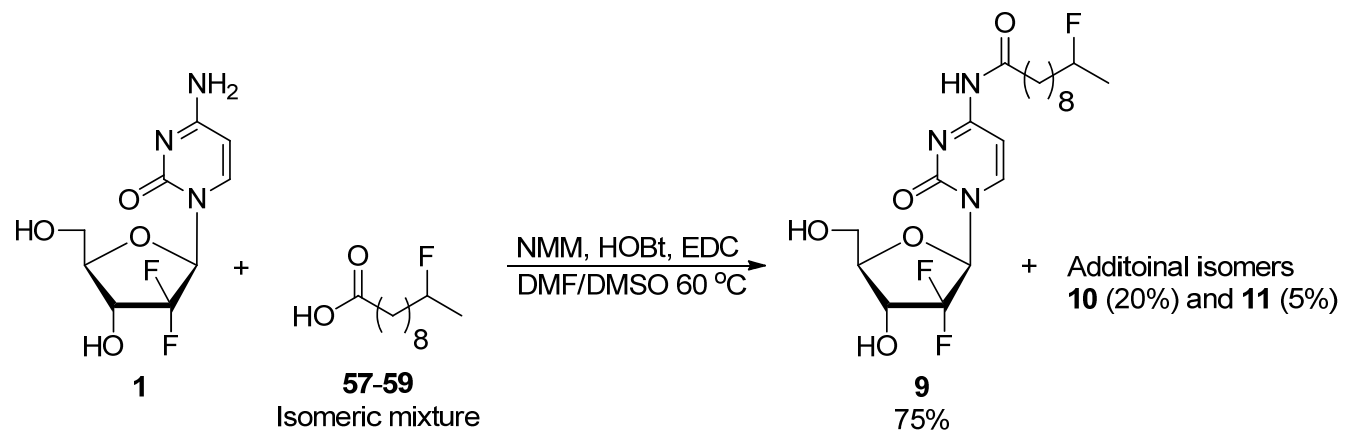

Scheme 10. Synthesis of the fluorinated 4- $N$-alkanoylgemcitabine regioisomeric mixture by peptide coupling conditions.

The same model fluorination study employed to give $\mathbf{9}$ was performed on terminally di-unsaturated analogue $\mathbf{8}$, yielding $\mathbf{1 2}$ as a complex isomeric mixture of addition products (Scheme 11). The regioisomeric mixture in this case was too complex to be characterized, likely owing to symmetric and un-symmetric carbocation migration on both chains. However, suprisingly, coupling of 4-fluoro-2-(2-fluoropropyl)pentanoic acid (51, as a complex regioisomeric mixture) to $\mathbf{1}$ using the peptide coupling conditions failed to yield the branched 4- $N$-fluoroalkanoyl analogue $\mathbf{1 2}$.
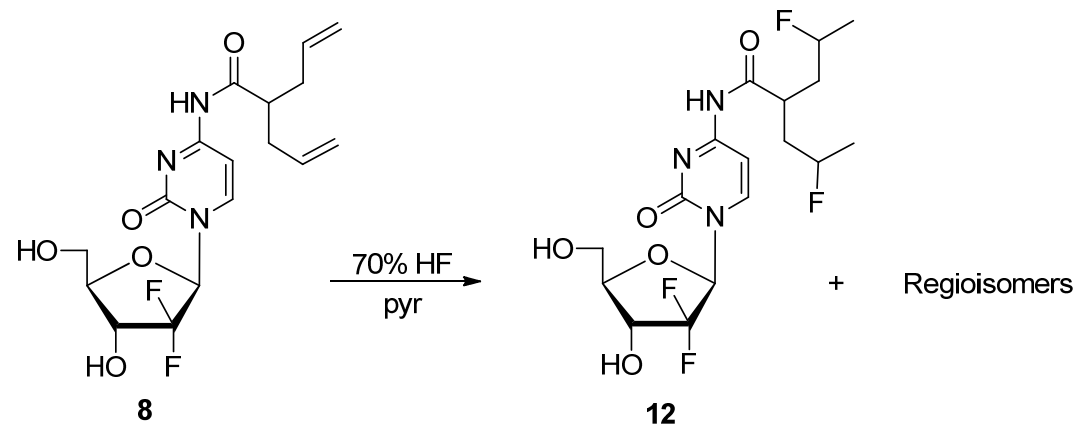

Scheme 11. Fluorination of olefinic 4- $N$-valproyl gemcitabine by treatment with HF/pyr.

Although the model fluorination was successful, the occurrence of multiple products in substantial amounts is less than appealing for the development of a marketable drug. Moreover, the reported low chemical efficiencies associated with radiofluorinations using 
$\left[{ }^{18} \mathrm{~F}\right]-\mathrm{HF},{ }^{156}$ due to the ${ }^{18} \mathrm{~F}$ radionuclides' relatively low abundance in comparison to ${ }^{19} \mathrm{~F}$ during generation of the $\mathrm{H}^{-18} \mathrm{~F} / \mathrm{pyr}$ reagent, made the process impractical for the development of a radioligand. The focus then became the development of alternative 4$\mathrm{N}$-alkanoylgemcitabine derivatives that would allow introduction of an ${ }^{18} \mathrm{~F}$ radionuclide by more conventional methods.

\subsubsection{Synthesis of $4-N$-alkanoylgemcitabine bearing other terminal groups}

The standard method for incorporation of an ${ }^{18} \mathrm{~F}$ radionuclide proceeds via $\mathrm{S}_{\mathrm{N}} 2$ type reaction, substituting a suitable leaving group such as bromide, mesylate or triflate with $\left[{ }^{18} \mathrm{~F}\right]-\mathrm{KF}$ in the presence of Kyrptofix. ${ }^{152,157}$ The reaction of $\mathbf{1}$ with 11-fluoroundecanoic acid (63, see section 3.1.11.2.) employing peptide coupling conditions afforded the desired 4- $N$-(11-fluoroundecanoyl)gemcitabine derivative $\mathbf{1 3}$ in $41 \%$ after isolation (Scheme 12).

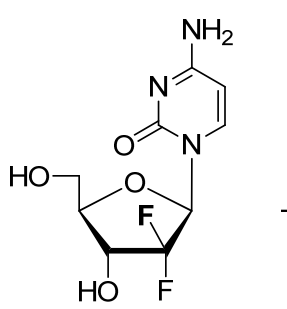

1

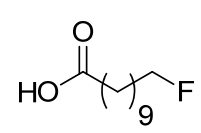

63

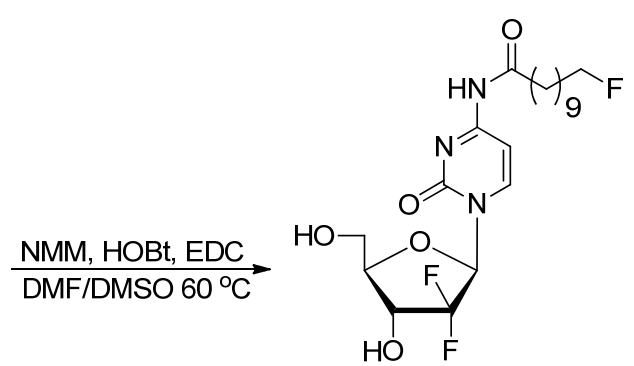

13

Scheme 12. Synthesis of the 4- $N$-alkanoylgemcitabine bearing a terminal fluorine.

A terminal bromine substituent was first considered for replacement during the model fluorination reaction. However, because of the labile nature of the bromide atom the condensation of 1 with commercially available 11-bromoundecanoic acid employing peptide coupling procedures led to the formation of the 4- $\mathrm{N}$-[11-(1H-benzotriazol-1- 
yloxy)undecanoyl]gemcitabine 14 (Scheme 13) instead of the desired terminal bromine functionalized analogue (i.e. 18, see Scheme 15).
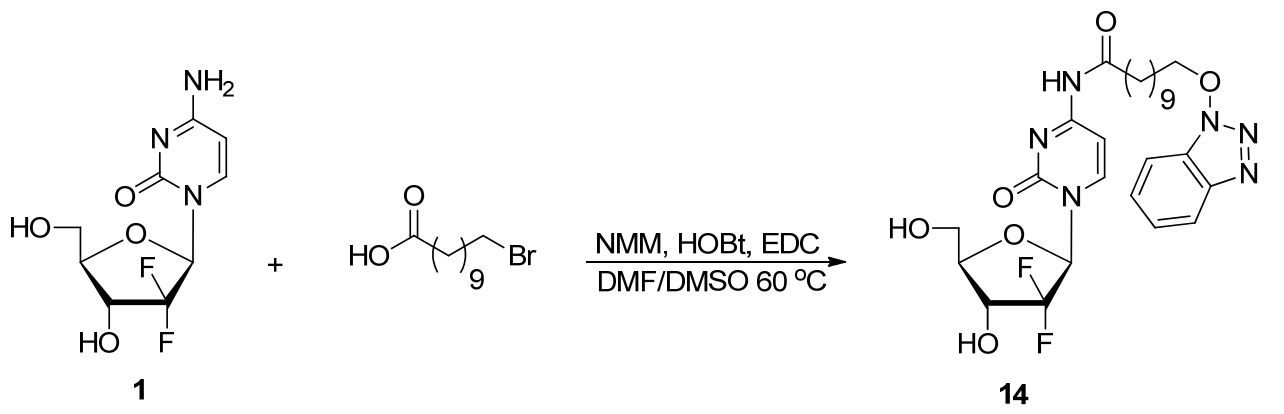

Scheme 13. Synthesis of 4- $N$-alkanoylgemcitabine bearing a terminal triazololate.

Therefore, alternative coupling methods were investigated with the aim of introducing the terminal bromine. Attempts to transiently protect $\mathbf{1}$ with a trimethylsilyl group $^{158}$ followed by treatment with 11-bromoundecanoic acid/CDI in the presence of pyridine led to the formation of the $4-N$-(11-chloroundecaoyl)gemcitabine 15 , featuring a terminal chlorine on the aliphatic chain. Employing a mixed anhydride procedure ${ }^{65}(11-$ bromoundecanoic acid/ethyl chloroformate/TEA) similarly afforded chloro-derivative $\mathbf{1 5}$ (Scheme 14). It seemed the bromine atom was more susceptible to displacement than initially anticipated.
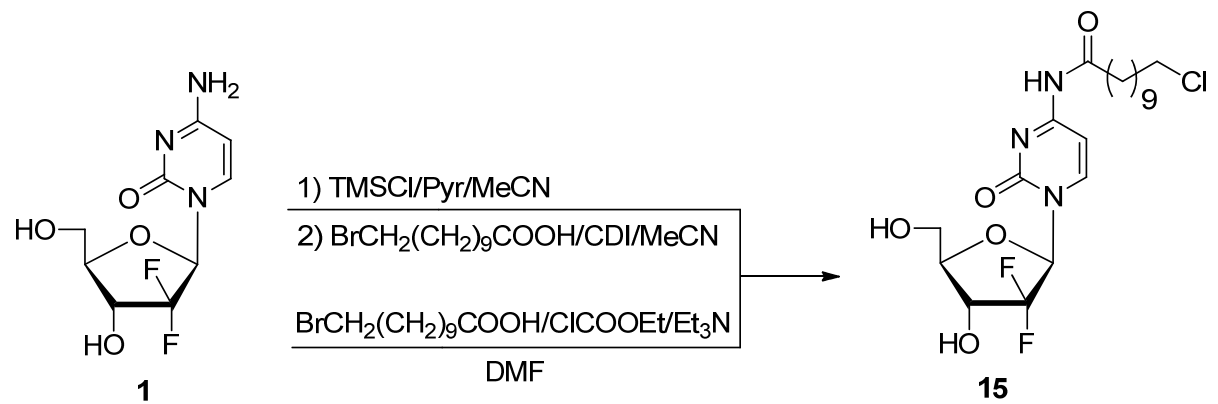

Scheme 14. Synthesis of 4- $N$-alkanoylgemcitabine bearing a terminal chlorine. 
In order to preserve the terminal bromine functionality, the $3^{\prime}, 5^{\prime}$-di- $O$-Boc protected $16^{159}$ was prepared as reported in literature by reaction of $\mathbf{1}$ with di-tert-butyl carbonate in the presence of $\mathrm{KOH}$ in 1,4-dioxane. ${ }^{159}$ The selective Boc-protections at 3'-OH and 5'$\mathrm{OH}$ positions allowed for condensation of $\mathbf{1 6}$ with corresponding 11-bromoundecanoyl chloride (64, see section 3.1.11.2.) in the presence of $\mathrm{NaHCO}_{3}$ at $0^{\circ} \mathrm{C}$ to give the desired Boc-protected Bromo derivative 17 in a 33\% isolated yield. Analogue 17 was deprotected with TFA to give the $4-N$-(11-bromoundecanoyl)gemcitabine $\mathbf{1 8}$, with the terminal bromine intact, to be screened for activity (Scheme 15).
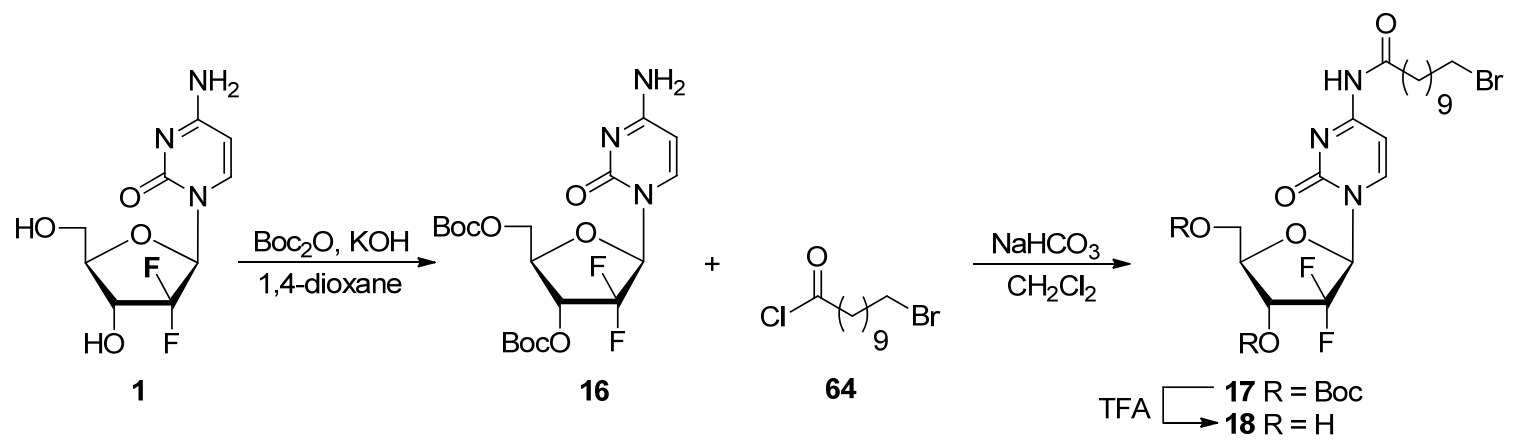

Scheme 15. Synthesis of the 4- $N$-alkanoylgemcitabine bearing a terminal bromine.

The branched, terminal bromine bearing 4- $N$-(5-bromo-2-propylpentanoyl) gemcitabine 19 (43\% yield) was similarly prepared by treatment of 16 with corresponding acyl chloride 5-bromo-2-propylpentanoyl chloride (55, see section 3.1.11.2.) in the presence of $\mathrm{NaHCO}_{3}$ (Scheme 16). 


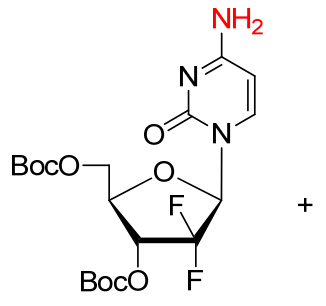

16

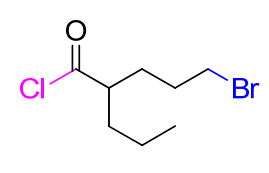

55

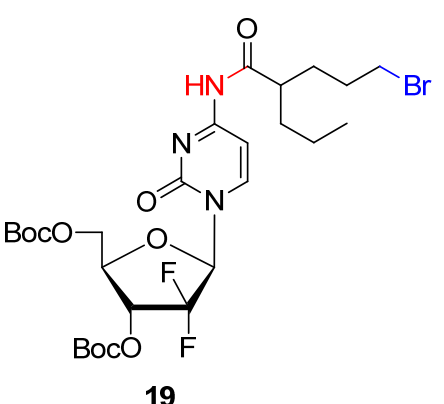

19

Scheme 16. Synthesis of the 4- $N$-bromovalproylgemcitabine bearing a terminal bromine.

In order to investigate alternative terminal moieties to be replaced during the $\mathrm{S}_{\mathrm{N}} 2$ mediated fluorination model studies, the Boc-protected terminal hydroxyl functionalized analogue $\mathbf{2 0}$ was prepared in a 37\% yield by treatment of $\mathbf{1 6}$ with commercially available 11-hydroxyundecanoic acid by employing the peptide coupling procedure. Deprotection of 20 with TFA gave 11-hydroxyundecanoyl analogue 21 (Scheme 17).

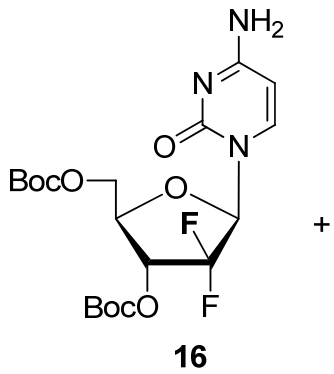

16<smiles>CC(C)(CO)C(=O)O</smiles>

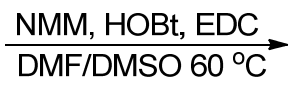

$\mathrm{RO}$

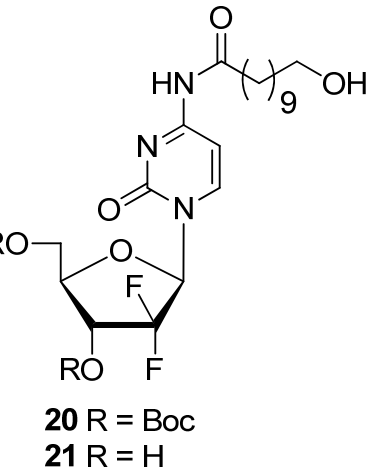

Scheme 17. Synthesis of the $4-N$-alkanoylgemcitabine bearing terminal hydroxyl group.

The terminal hydroxyl functionality allowed for a versatile means of introducing $\mathrm{S}_{\mathrm{N}} 2$ susceptible leaving groups. Treatment of $\mathbf{2 0}$ with trifluoromethanesulfonic anhydride afforded the Boc-protected Triflate analogue 22 (Scheme 18). As a result of the labile nature of the primary triflate, which is expected to be highly susceptible to $\mathrm{S}_{\mathrm{N}} 2$ type replacement by a fluoride anion, preparation of pure triflate $\mathbf{2 2}$ was troublesome and gave a mixture of elimination and hydrolyzed by-products. 

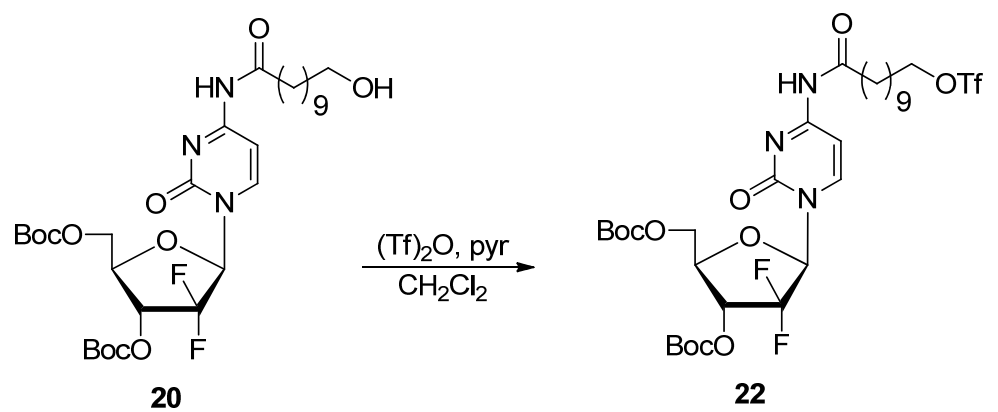

Scheme 18. Synthesis of the $4-N$-alkanoylgemcitabine bearing terminal triflate.

Initial attempts employing the conventional radiosynthetic procedures for introducing a fluorine atom via $\mathrm{S}_{\mathrm{N}} 2$ type reaction, discussed later, when using the $4-\mathrm{N}-$ alkanoylgemcitabines $\mathbf{1 7}, \mathbf{1 9}$, or $\mathbf{2 2}$ as the substrate failed to yield the desired fluorination products; frequently giving instead the elimination product 5 or had no reaction at all. Moreover, cleavage of the amide linkage resulting in regeneration of $\mathbf{1 6}$ was also observed to occur under the radiosynthetic conditions, which use strong bases or basic solvents at elevated temperatures (upward of $\sim 100{ }^{\circ} \mathrm{C}$ ) in their deprotection steps. However, not all fluorination reagents which use fluoride (F-) as a fluorine source and that are applicable to radiofluorination were out of the scope of this work. The direct fluorination of $\mathbf{2 0}$ with DAST afforded the protected 4- $N$-(11-fluoroundecanoyl) derivative 23 (40\%), which could be further deprotected with TFA gave 13 (Scheme 19). However, a major drawback for the use of $\left[{ }^{18} \mathrm{~F}\right]$-DAST would be that it is highly volatile and reacts violently with water. The preparation of $\left[{ }^{18} \mathrm{~F}\right]$-DAST additionally proceeds with low radiochemical yields. ${ }^{160}$ It should also be mentioned that $\mathbf{2 3}$ could alternatively be prepared by applying peptide coupling conditions to $\mathbf{1 6}$ with 11-fluoroundecanoic acid. However, application of peptide coupling conditions to 3'-5' protected gemctiabines typically precedes in low yields. 


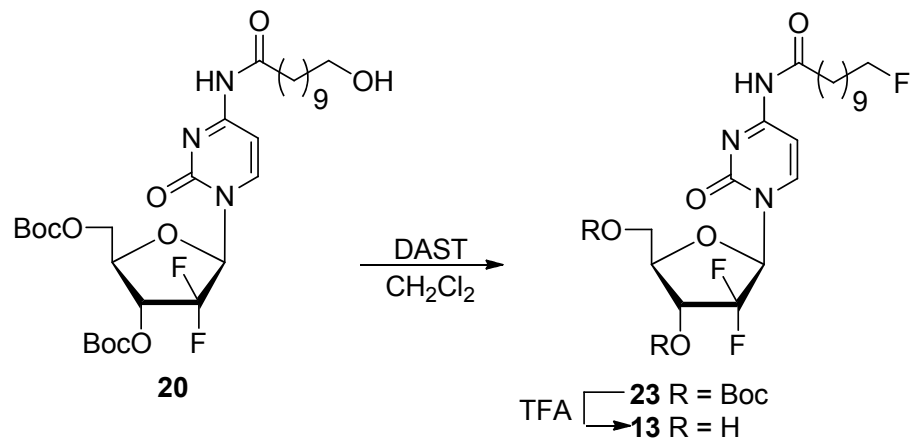

Scheme 19. Fluorination of a 4- $N$-alkanoylgemcitabine with DAST.

A comparison to the 4- $\mathrm{N}$-alkanoylgemcitabines was still needed that preferably had similar lipophilic characteristics yet lacking hydrolyzable the carbonyl moiety, which may clarify any direct role the lipophilic side chain plays in the metabolism of these analogues.

\subsubsection{Synthesis of 4- $N$-alkylgemcitabines bearing a terminal methyl or olefin.}

The 4- $N$-alkyl modification offers direct evidence towards the anticancer properties related to the long lipophilic chain while avoiding limitations associated with stability of the amide linkage during deprotection of a $4-\mathrm{N}$-alkanoyl radioligand. From existing methods known in literature for the 4- $N$-alkylation of cytosine-based nucleosides, ${ }^{161-164} 4$ $\mathrm{N}$-alkylation of gemcitabine was most efficiently achieved efficiently by displacement of a toluenesulfonamido group ${ }^{163}$ with corresponding aliphatic alkyl amines to give the 4- $N$ alkylgemcitabines. Thus, tosylation of $\mathbf{1 6}$ with $\mathrm{TsCl}$ in the presence of $\mathrm{Et}_{3} \mathrm{~N}$ in 1,4dioxane afforded protected 4-N-tosyl gemcitabine $\mathbf{2 4}$. Treatment of $\mathbf{2 4}$ with either neat $\mathrm{n}$ butyl amine or 10-undecenyl amine effected simultaneous displacement at $\mathrm{C} 4$ of cytosine ring and deprotection to afford 4-N-butyl 25 and 4-N-(10-undecenyl) derivative 26, in $50 \%$ and $36 \%$ yield respectively (Scheme 20 ). 


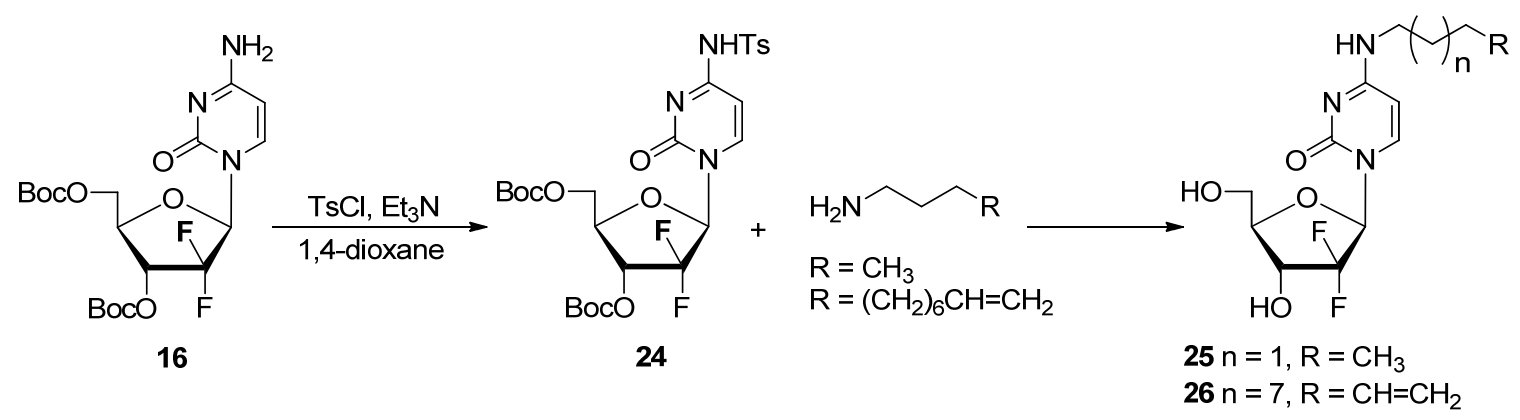

Scheme 20. Synthesis of 4- $N$-alkylgemcitabines by nucleophilic aromatic substitution.

Conventionally, the 4- $\mathrm{N}$-alkylation of the exocyclic amine of the cytosine base ring of gemcitabine is believed to produce inactive metabolites. In our preliminary screening the long-alkyl modification was observed overall to produce less active gemcitabine analogues in comparison to gemcitabine and the 4- $N$-alkanoylgemcitabines. The observed activity for this class of compounds advocated the $4-\mathrm{N}$-alkyl modification as yet being therapeutically relevant depending on cancer type. The results from the preliminary cytotoxic screening prompted the exploration of $4-\mathrm{N}$-alkylgemcitabines with similar terminal functionalities described herein for the 4-N-alkanoyl gemcitabine derivatives.

\subsubsection{Synthesis of the fluorinated 4- $N$-alkylgemcitabine by addition of HF/pyr.}

Although incorporation of ${ }^{18} \mathrm{~F}$ via treatment with $\mathrm{H}^{18} \mathrm{~F} / \mathrm{pyr}$ is not practical process for imaging, fluorinated analogues $\mathbf{9}$ and $\mathbf{1 2}$ were active metabolites even as regioisomeric mixture, hence the fluorinated 4-N-alkylgemcitabine counterpart merited characterization. Direct fluorination of $\mathbf{2 6}$ with $\mathrm{HF} / \mathrm{pyr}$ in a chilled HDPE vessel at $0{ }^{\circ} \mathrm{C}$ yielded a regioisomeric mixture of 27-29 with an isomeric ratio of 20:45:35 (Scheme 21);

${ }^{19} \mathrm{~F}$ NMR was diagnostic for the regioisomeric composition [ $\delta$-183.01 (m, $\left.0.2 \mathrm{~F}\right),-181.90$ $(\mathrm{m}, 0.45 \mathrm{~F})$ and $-173.68(\mathrm{~m}, 0.35 \mathrm{~F})]$. Interestingly the 9-fluoroundecanyl isomer was the 
major product rather than the expected 10-fluoroundecanyl regioisomer, as was observed with its 4- $N$-alkanoylgemcitabine counterpart 9-11.

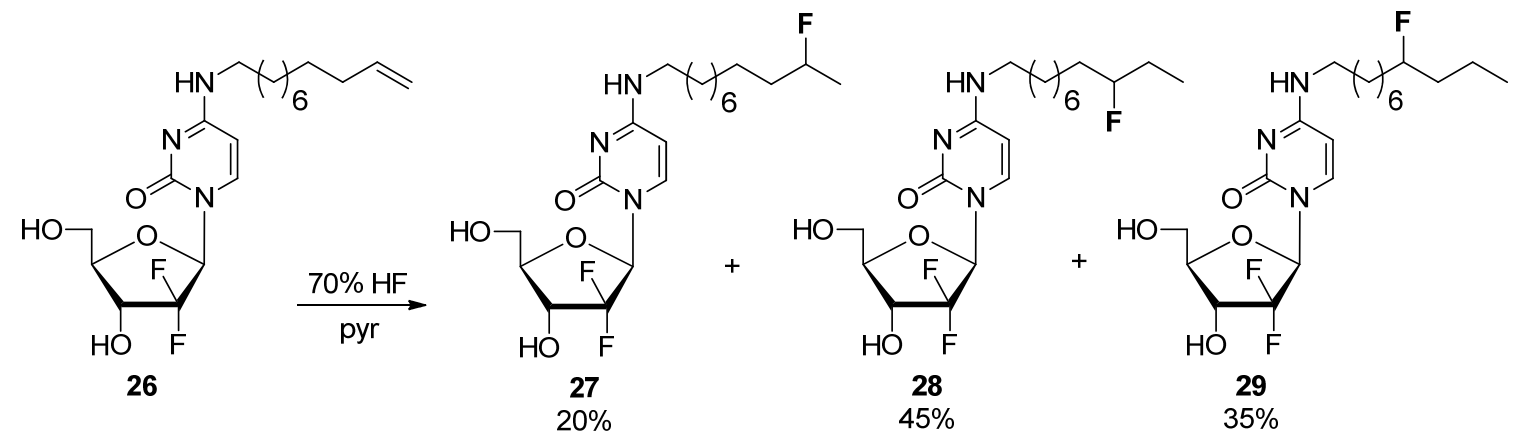

Scheme 21. Fluorination of 4- $N$-alkylgemcitabine olefin by addition of HF/pyr.

\subsubsection{Synthesis of the $4-N$-alkylgemcitabines bearing other terminal groups.}

To meet the criteria of conventional retrosynthetic procedures, which employ $\left[{ }^{18} \mathrm{~F}\right]-$ $\mathrm{KF}$ as a ligand source, development of an " $\mathrm{S}_{\mathrm{N}} 2$-friendly" derivative was necessary. Treatment of 4- $N$-tosyl derivative $\mathbf{2 4}$ with corresponding alkyl-amines however simultaneously deprotected the $3^{\prime}$ and $5^{\prime}$ positions of the sugar moiety. Specifically, reaction of 24 with the necessary 11 -aminoundecanol 66 in the presence of $\mathrm{Et}_{3} \mathrm{~N}$ in 1,4dioxane resulted in substantial 5'-O-monoprotected intermediate $\mathbf{3 0}(53 \%)$ as well the fully de-protected analogue 31 (24\%) (Scheme 22).

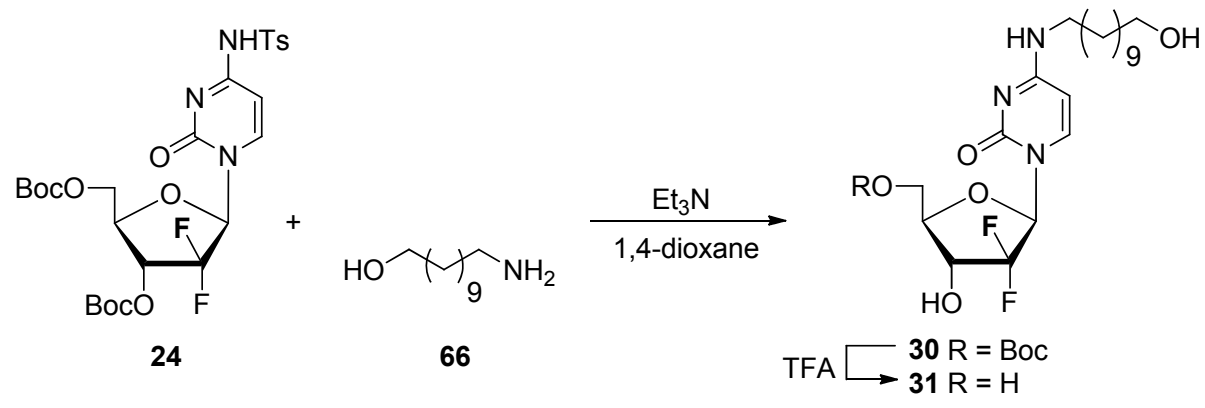

Scheme 22. Synthesis of the 4- $N$-alkylgemcitabine bearing a terminal hydroxyl group. 
Exposure of the 5'-OH and 3'-OH groups in the ribose ring following alkylation made the selective fluorination of the primary hydroxyl group on the 4- $\mathrm{N}$-alkyl chain (e.g. in 31) unmanageable. Therefore, it was necessary to have a selective protectiondeprotection strategy in place prior to the alkylation. Transient protection and subsequent tosylation of gemcitabine $\mathbf{1}$ yielded $\mathbf{3 2}$ after deprotection with methanolic ammonia. The tosyl modification in turn was directly replaced by treatment with $O$-benzyl protected 11 aminoundecanol $\mathbf{7 0}$ to give 33, introducing the desired hydroxyl functionality already protected rather than attempting a selective protection in the presence of $3^{\prime}-\mathrm{OH}$ and 5'-OH groups. Thus, benzoylation of $\mathbf{3 3}$ yielded the fully protected $\mathbf{3 4}$. Selection of the benzyl protection when preparing the 11-aminoundecanyl benzyl ether would now allow for selective deprotection of the 4-N-(11-O-benzylundecanyl)-protection via lengthy treatment with CAN, while maintaining integrity of the 3 ',5'-dibenzoyl protections, to give 35, the desired precursor for introduction of ${ }^{18} \mathrm{~F}$ radioligand (Scheme 23). Other attempts at a PMB protection strategy were unsuccessful since we were unable to synthesize the $O$-para-methoxybenzyl protected 11-aminoundecanol. Also, an $O$-trityl protected 11-aminoundecanol was prepared however it failed to react with the $4-\mathrm{N}$ tosylgemcitabine $\mathbf{3 2}$. 


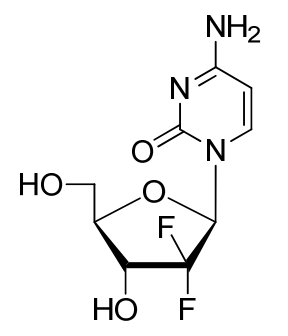

1

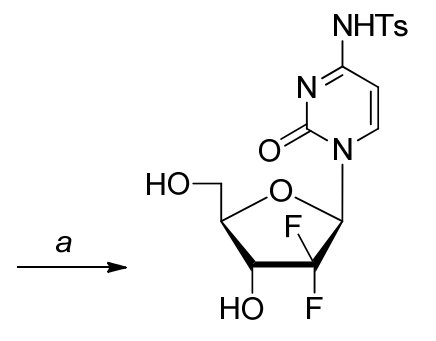

32

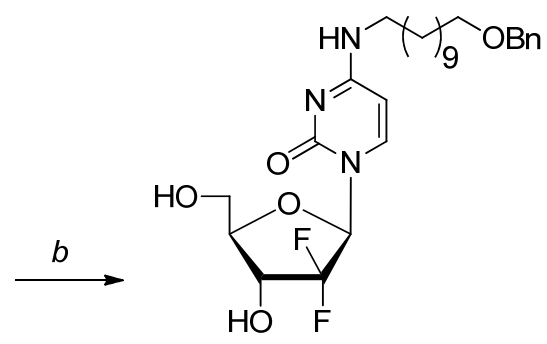

33

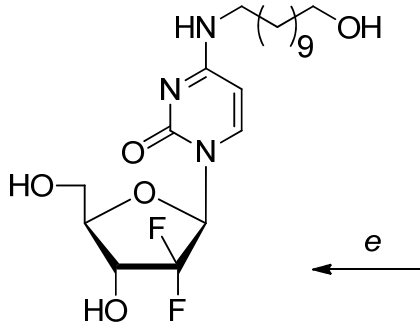

31

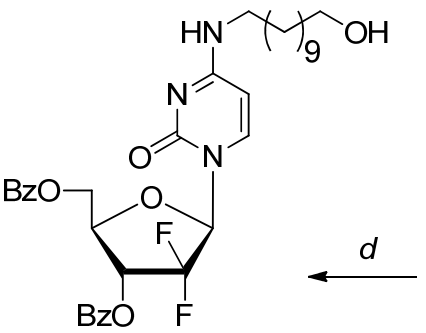

35

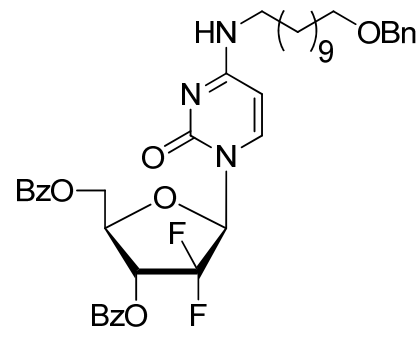

34

Scheme 23. Synthesis of 4- $N$-alkylgemcitabine bearing a terminal hydroxyl for the model fluorination with $\mathrm{KF} / \mathrm{K} 222$. Reagents and conditions: (a) (i) TMSCl, pyridine, (ii) $\mathrm{TsCl}$, (iii) $\mathrm{MeOH} \cdot \mathrm{NH}_{3}$; (b) $\mathrm{BnO}\left(\mathrm{CH}_{2}\right)_{11} \mathrm{NH}_{2}, \mathrm{Et}_{3} \mathrm{~N}$, 1,4-dioxane; (c) 2,6-Lutidene, DMAP, $\mathrm{BzCl}, \mathrm{CH}_{2} \mathrm{Cl}_{2}$; (d) $\mathrm{CAN}, \mathrm{CH}_{3} \mathrm{CN}$; (e) $\mathrm{MeOH} \bullet \mathrm{NH}_{3}$.

It should be noted that other attempts were also made for the selective deprotection of 34 via Pd-C catalyzed hydrogenation (Scheme 24). However treatment of 34 led to the partial hydrogenation and reduction of the cytosine ring. The undesired 5,6dihydrocytosine derivative $\mathbf{3 6}$ was isolated from the reaction mixture and its structure was established by MS $\left(\mathrm{ESI}^{+}\right) \mathrm{m} / z 643\left(100,[\mathrm{M}+\mathrm{H}]^{+}\right)$as well as by observed loss of characteristic cytosine absorbance for UV at $275 \mathrm{~nm}$. 


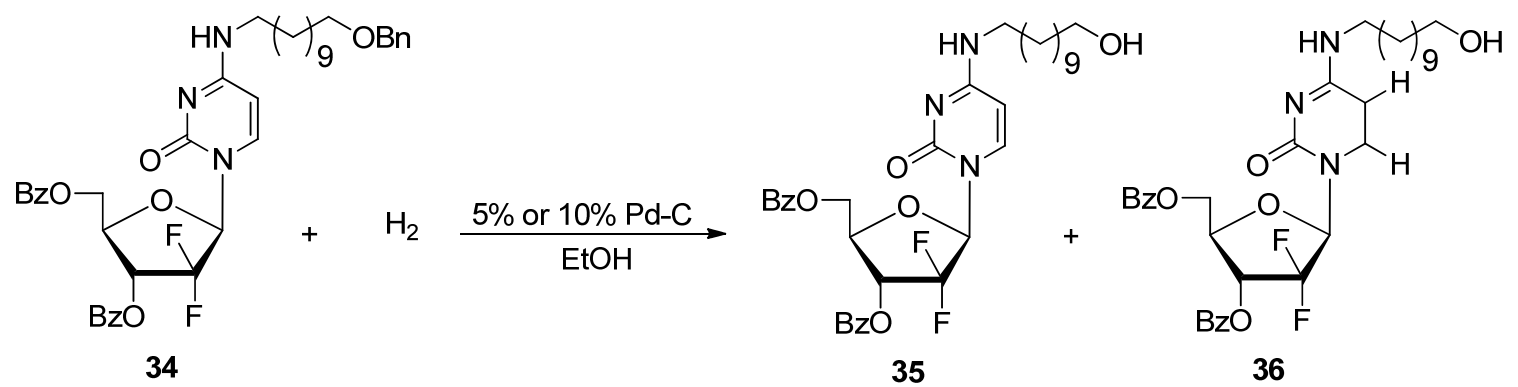

Scheme 24. Debenzylation of the 4- $N$-alkylgemcitabine by hydrogenation with $\mathrm{H}_{2}$.

Treatment of the terminal hydroxyl functionalized analogue 35 with $\mathrm{MsCl}$ (1.1 eq) and $\mathrm{Et}_{3} \mathrm{~N}$ (1.5 eq) in $\mathrm{CH}_{2} \mathrm{Cl}_{2}$ afforded 37. The mesylate precursor 37 is a suitable substrate for the model fluorination studies simulating conventional radiosynthetic conditions (Scheme 25).

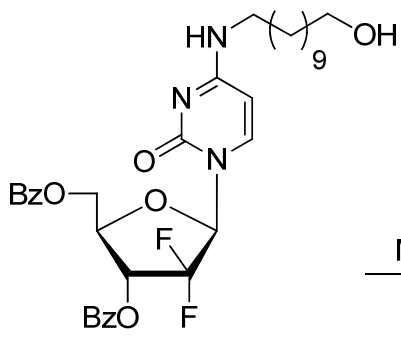

35

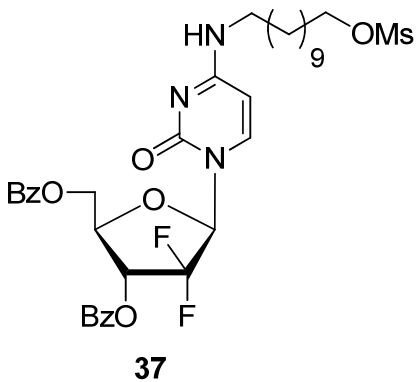

Scheme 25. Synthesis of 4- $N$-alkylgemcitabine bearing a terminal mesylate.

\subsubsection{Fluorination of the $4-N$-alkylgemcitabine with DAST.}

However, prior to beginning model fluorination studies employing KF as a fluoride source, analogue 38 was prepared via direct fluorination of $\mathbf{3 5}$ with DAST. Subsequent deprotection of $\mathbf{3 8}$ with methanolic ammonia afforded the desired $\mathbf{3 9}$ (Scheme 26). 


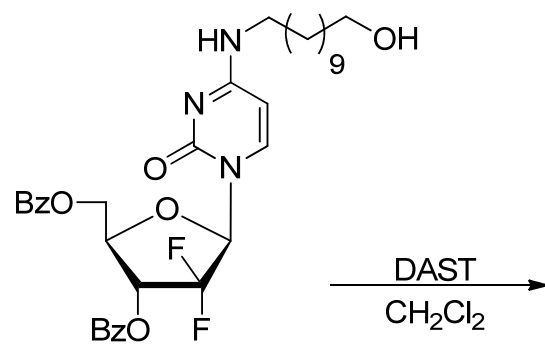

35

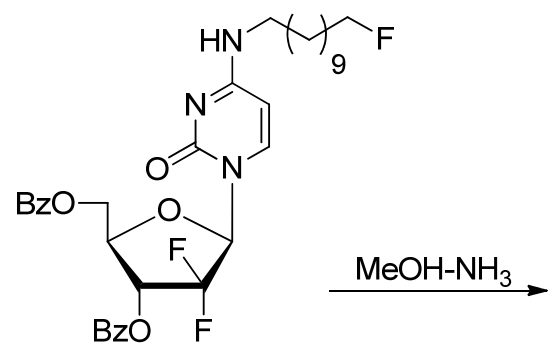

38

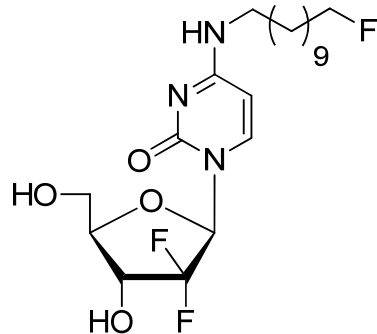

39

Scheme 26. Fluorination of 4- $N$-alkylgemcitabine with DAST.

With standards for $\mathbf{3 8}$ and $\mathbf{3 9}$ in hand, the model fluorination was investigated mimicking the conventional radiosynthetic protocol as closely as possible. Reaction of $\mathbf{3 7}$ with $\mathrm{KF}$ in the presence of $\mathrm{K}_{2} \mathrm{CO}_{3}$ and Kryptofix 222 was carried out in $\mathrm{CH}_{3} \mathrm{CN}$ at $110^{\circ} \mathrm{C}$ for $18 \mathrm{~min}$ in a heavy walled cylindrical pressure vessel with screw cap to give $\mathbf{3 8}$. After quick cooling and short vacuum filtration into another pressure vessel, the effluent was concentrated in vacuo and treated with $0.5 \mathrm{M} \mathrm{CH}{ }_{3} \mathrm{ONa}$ in $\mathrm{MeOH}(1 \mathrm{~mL})$ and stirred at $100{ }^{\circ} \mathrm{C}$ for $8 \mathrm{~min}$. The reaction mixture was neutralized with $1 \mathrm{~N} \mathrm{HCl}$ and concentrated to dryness (Scheme 27). The desired fluorinated 4- $N$-fluoroalkylgemcitabine 39 was found to be stable at that level; characterized by HPLC retention time and LC-MS $\left(\mathrm{ESI}^{+}\right) \mathrm{m} / \mathrm{z}$ 436.3.

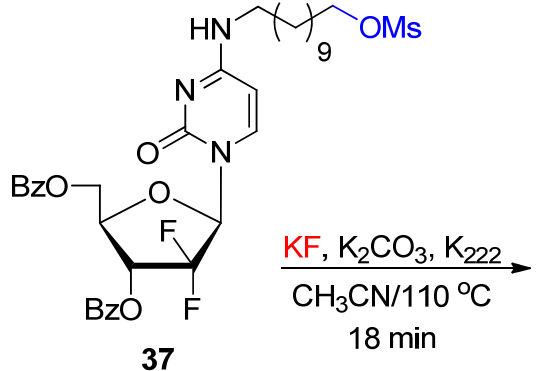

37

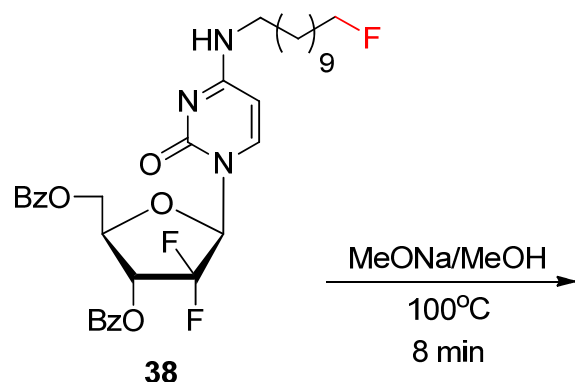

38

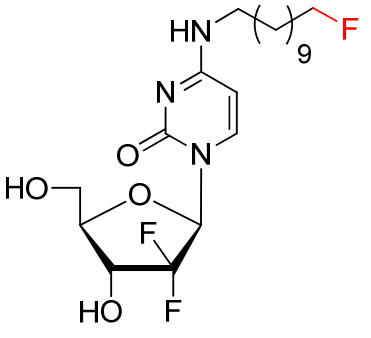

39

Scheme 27. Model fluorination of 4- $N$-alkylgemcitabine with KF/K222. 
Purification by HPLC for the fluorinated 4- $N$-alkylgemcitabine 39 was also characterized to meet criteria for radiosynthesis of the $\left[{ }^{18} \mathrm{~F}\right]$-radioisomer. Therefore, the neutralized sample was injected into a into a Phenomenex Gemini semi-preparative RPC18 column $(5 \mu, 25 \mathrm{~cm} \mathrm{X} 1 \mathrm{~cm})$ via $5 \mathrm{~mL}$ loop and eluted with isocratic mobile phase mixture $45 \% \mathrm{CH}_{3} \mathrm{CN}$ in $\mathrm{H}_{2} \mathrm{O}$ at a flow rate $=5 \mathrm{~mL} / \mathrm{min}$. The 4-N-fluoroalkylgemcitabine 39 eluted with $\mathrm{rt}=13.1 \mathrm{~min}(62 \%$ overall yield $)$ with nearest observable impurities separated by approximately $2.5 \mathrm{~min}(\mathrm{rt}=11.5$ and 16.0min) (Figure 12).

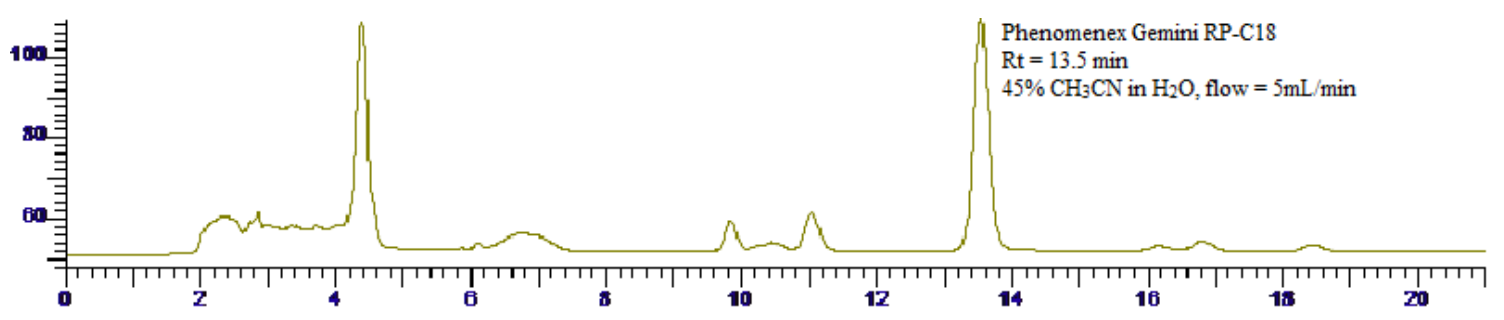

Figure 12. HPLC chromatogram of neutralized sample from model fluorination with KF.

Having now established a protocol suitable for working with $\left[{ }^{18} \mathrm{~F}\right]$ and a $4-N$-modified gemcitabine analogue, attention was directed towards the development of 4-N-alkanoyl and 4- $N$-alkyl gemcitabine analogues compatible with alternative radionuclides.

\subsubsection{Direct conjugation of gemcitabine with bifunctional chelators.}

As previously mentioned (Section 1.2.2.), bifunctional chelators rely on reactive functional groups (typically an electrophilic group such as an acetate) for their conjugation to a metabolite of interest. The initial concept for generating a $\left[{ }^{68} \mathrm{Ga}\right]-4-\mathrm{N}$ alkanoylgemcitabine radioligand was the direct conjugation of commercially available 4(4,7-bis(2-tert-butoxy-2-oxoethyl)-1,4,7-triazonan-1-yl)-5-tert-butoxy-5-oxopentanoic acid (NODA-GA(tBu) $)_{3}$ ) to gemcitabine using previously employed peptide coupling 
conditions. Under those conditions, the protected NODA-4- $N$-alkanoylgemcitabine conjugate 40 was prepared and identified by ${ }^{1} \mathrm{H}$ NMR and LC-MS $\left(\mathrm{ESI}^{+}\right) \mathrm{m} / z 789$. However, analogue $\mathbf{4 0}$ was not found to be stable and was observed to slowly decompose back into 1. Deprotection of $\mathbf{4 0}$ with TFA afforded the desired NODA-GA-4- $N$ alkanoylgemcitabine conjugate 41 (Scheme 28) precursor for labeling, but also promoted further decomposition to $\mathbf{1}$. Although $\mathbf{4 1}$ was successfully prepared, implementation of a $\left[{ }^{68} \mathrm{Ga}\right]$ label proved to be more difficult than initially anticipated and attempts to incorporate the radionuclide were unsuccessful. It was speculated that trace amounts of metal ions present throughout the synthesis and which may have been adequate to chelate with the NODA-GA effectively blocked the site for introduction of a Gallium atom.

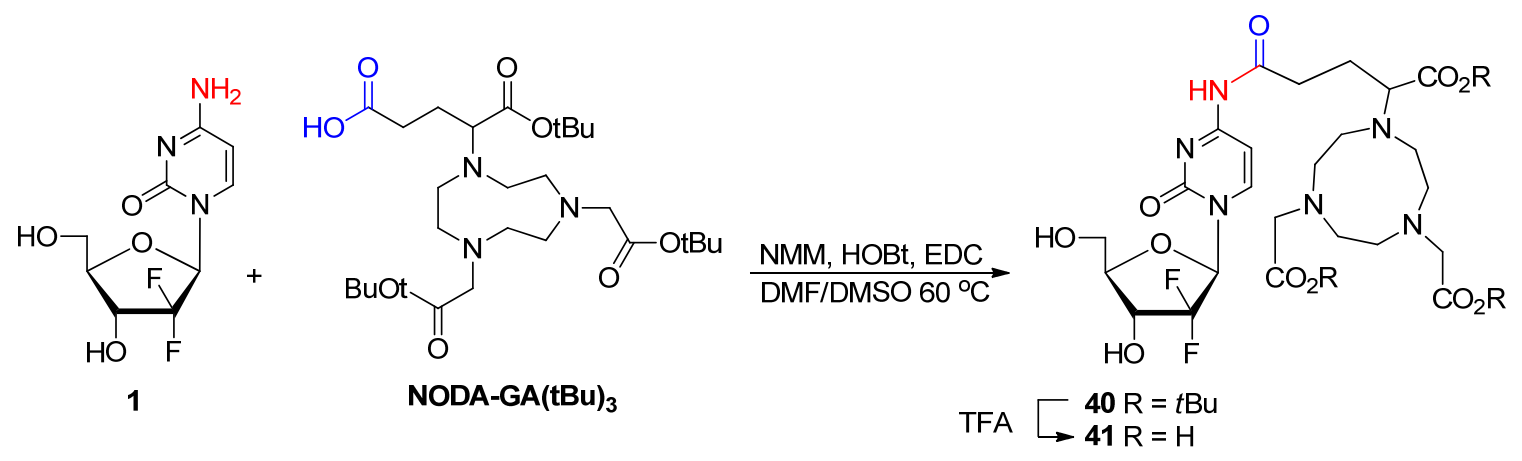

Scheme 28. Synthesis of the 4- $N$-(NODA-GA)gemcitabine conjugate.

In order to circumvent possible metal ion contaminations, 2-( $p$ isothiocyanatobenzyl)-1,4,7-triazacyclononane-1,4,7-triacetic acid (SCN-Bz-NOTA) was considered to be directly conjugated to gemcitabine. Conjugation of SCN-Bz-NOTA exploits the predisposition of amines to readily undergo condensation with thioisocynates to give amine-thiourea derivatives in high yields and also minimizes the amount of reagents, thought to be most probable source of metal ion contamination. However, the condensation of 1 with SCN-Bz-NOTA in $0.1 \mathrm{M}$ sodium carbonate buffer $(\mathrm{pH}=9.5)$ 
failed to produce the corresponding SCN-Bz-NOTA-4- $N$-alkanoylgemcitabine conjugate 42 (Scheme 29) $)^{143}$ owing to the poor nucleophilicity of the exocyclic amine of gemcitabine's cytosine base ring.

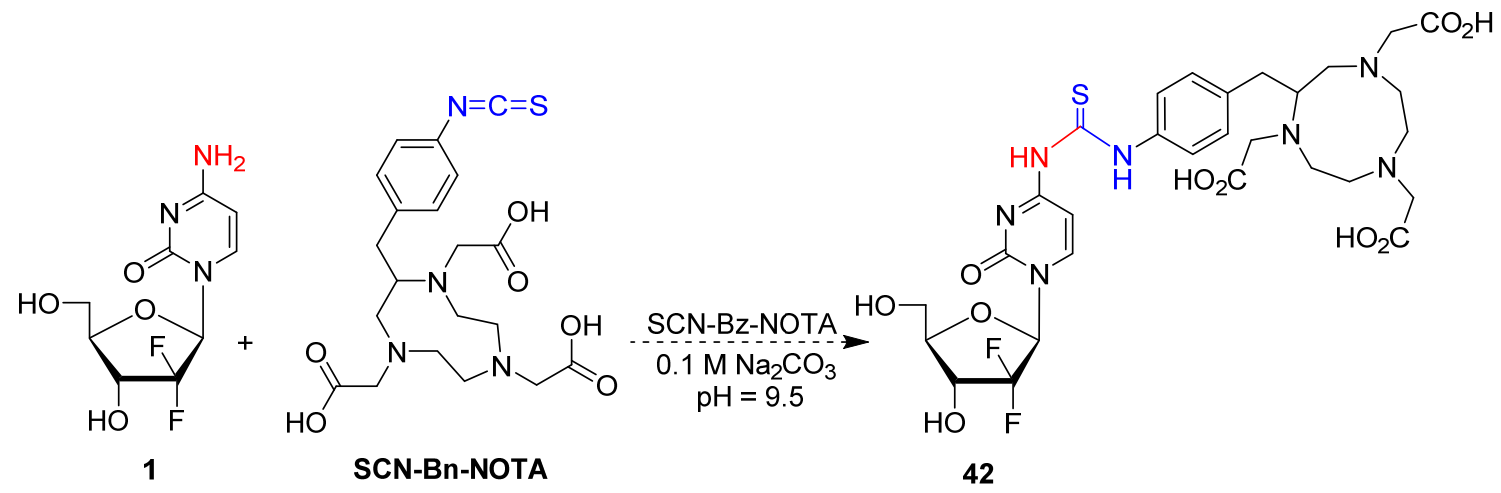

Scheme 29. Attempted preparation of the 4- $N-(\mathrm{SCN}-\mathrm{Bn}-\mathrm{NOTA})$ gemcitabine conjugate.

\subsubsection{Attempted synthesis of the $4-N$-alkanoylgemcitabine bearing a terminal amine for conjugation to bifunctional chelators.}

The " 2 nd generation" $4-N$-alkanoylgemcitabine derivative bearing a more nucleophilic aliphatic amine for conjugation to SCN-Bz-NOTA was later explored as an alternative to the direct conjugation with gemcitabine previously mentioned. Gemcitabine 1 was reacted with commercially available $N$-Boc- $\beta$-alanine using peptide coupling procedures to afford the $N$-protected 4- $N$-(11-aminoundecanoyl) gemcitabine derivative $\mathbf{4 3}$ (Scheme 30). The deprotection of $\mathbf{4 3}$ with TFA was surprisingly problematic to control and led to cleavage of the amide linkage. Pending characterization of a suitable deprotection strategy for $\mathbf{4 3}$, the primary amine on the $4-N$-(3-aminopropanoyl) derivative 44 is expected to react with commercially available SCN-Bz-NOTA to give a SCN-Bz-NOTA4- $N$-alkanoylgemcitabine radioligand precursor. A similar acyl linker with a base labile $\mathrm{N}$-Fmoc proctection was also considered as a viable route to the desired 4- $\mathrm{N}-(3-$ 
aminopropanoyl) derivative $\mathbf{4 4}$. However, coupling of commercially available $N$-Fmoc- $\beta$ alanine failed to give the desired 4- $\mathrm{N}$-alkanoyl gemcitabine derivative.

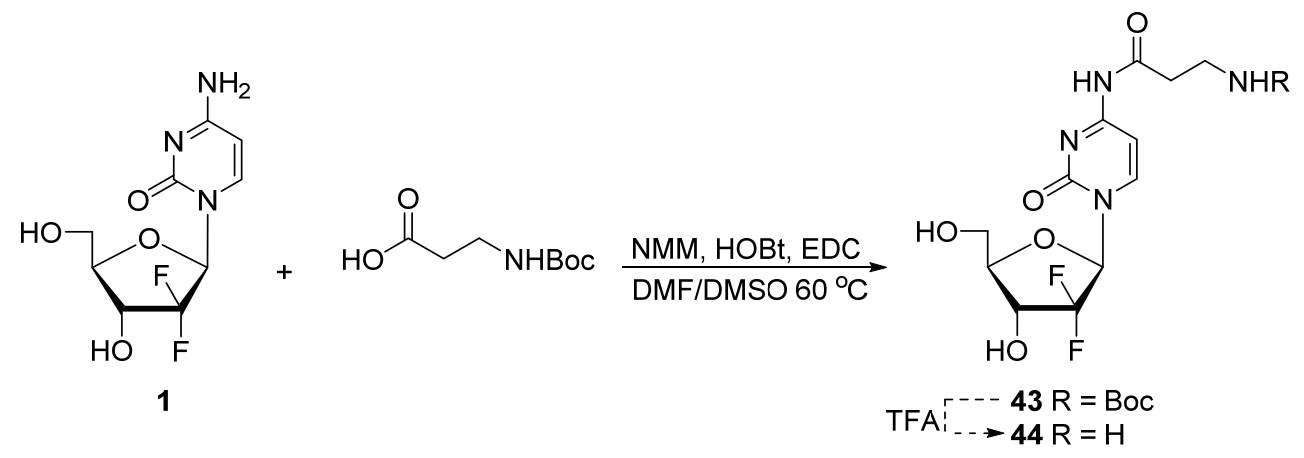

Scheme 30. Synthesis of 4- $N$-alkanoylgemcitabine with linker bearing a terminal amine.

Therefore, attention was diverted towards the development of the analogues " 2 nd generation" 4- $N$-alkyl gemcitabine derivative bearing and aliphatic amine.

\subsubsection{Synthesis of the $4-N$-alkylgemcitabine bearing a terminal amine for conjugation to bifunctional chelators.}

The non-hydrolyzable $4-\mathrm{N}$-alkylgemcitabine 45 bearing a terminal amine on the short alkyl linker was successfully prepared (Scheme 31) by reaction of commercially available $N$-Boc-1,3-propanediamine with 24. Deprotection of $\mathbf{4 5}$ with TFA gave the desired 4-N-(3-aminopropanyl) derivative $\mathbf{4 6}$ bearing a terminal amine, ideal for the proposed thioisocyante condensation. Analogue 46 was also prepared more efficiently ( $94 \%$ overall yield) as a "one-pot" synthesis starting from 32, skipping isolation of $\mathbf{4 5}$. 


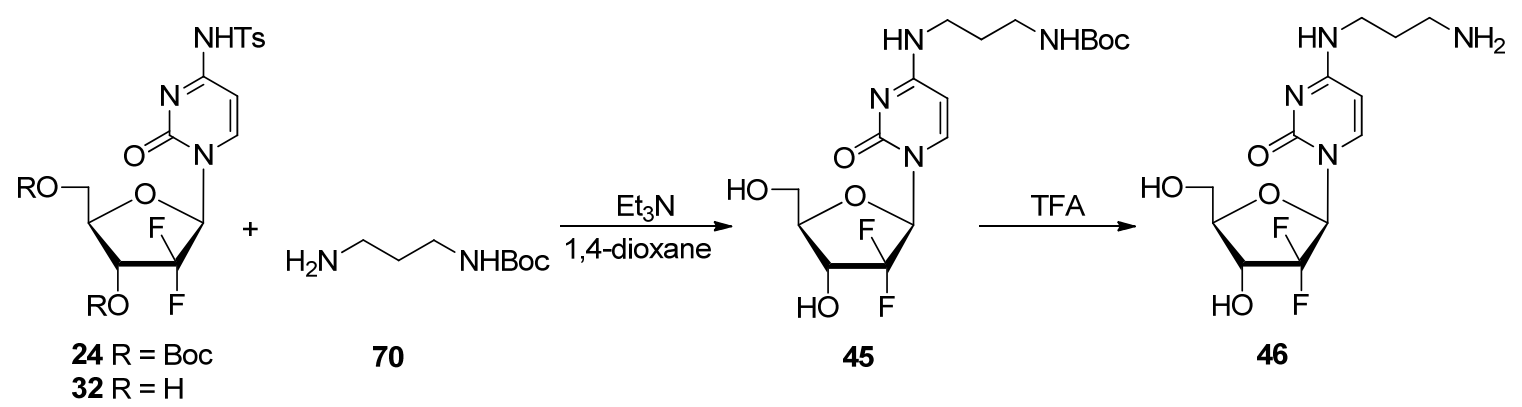

Scheme 31. Preparation of 4- $N$-alkylgemcitabine with linker bearing a terminal amine.

Condensation of 46 with SCN-Bz-NOTA in $0.1 \mathrm{M} \mathrm{Na}_{2} \mathrm{CO}_{3}$ buffer $(\mathrm{pH}=11)$ at ambient temperature was found to be a slow process, the reaction occurring over a 48-72 $\mathrm{h}$ period, however it inevitably afforded the 4- $N$-(3-SCN-Bz-NOTApropanyl)gemcitabine conjugate 47 (Scheme 32); identified by HRMS $\left(\mathrm{ESI}^{+}\right) \mathrm{m} / \mathrm{z}$ 771.2879 and found to be relatively stable at that level.
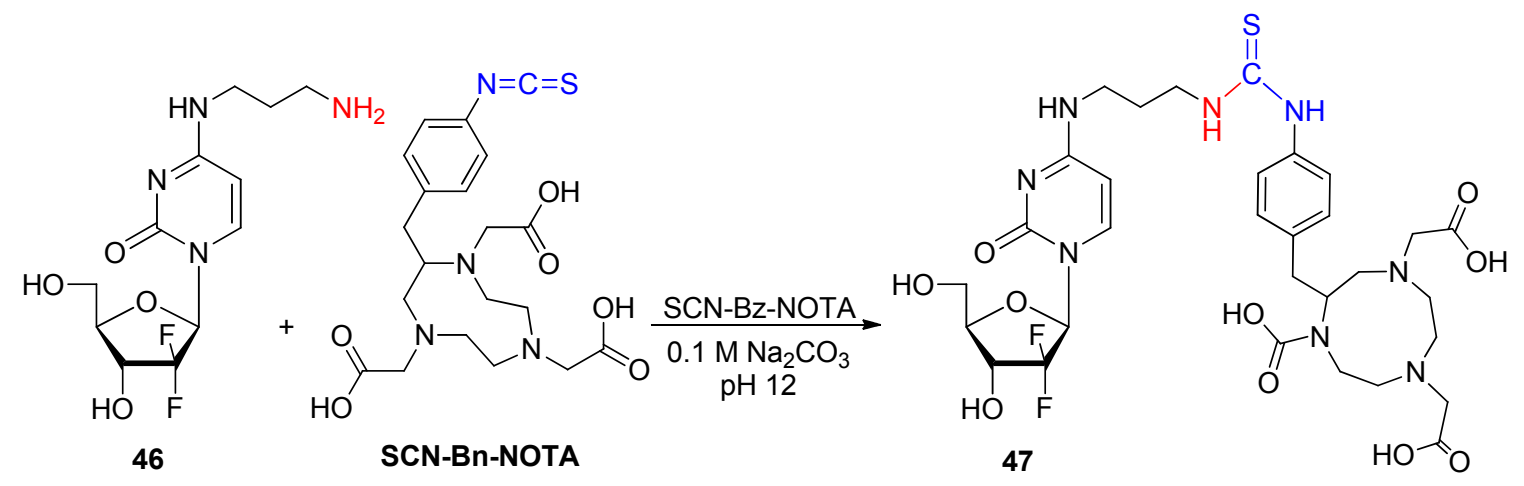

Scheme 32. Preparation of the NOTA-4- $N$-alkylgemcitabine conjugate.

Incubation of 47 with excess of gallium(III) chloride $\left(\mathrm{GaCl}_{3}\right)$ mimicking radiosynthetic conditions $\left(0.6 \mathrm{~N} \mathrm{NaCH}_{3} \mathrm{CO}_{2} / \mathrm{H}_{2} \mathrm{O}, \mathrm{pH}=9.3\right)$ with an extended reaction time (30 min instead of $15 \mathrm{~min}$ ) gave the Gallium-SCN-Bz-NOTA-4- $N$-alkylgemctiabine conjugate 48; characterized by HPLC retention time and HRMS (ESI+) $m / z$ 837.1977. The observed retention times for the labeling precursor $47(\mathrm{rt}=14.1)$ and the gallium 
complexed $48(\mathrm{rt}=12.4 \mathrm{~min})$ met criteria for working with $\left.\left[{ }^{68} \mathrm{Ga}\right]\right]^{3+}$ and can be applied towards the radiosynthesis of the $\left[{ }^{68} \mathrm{Ga}\right]-\mathbf{4 8}$ radioligand.

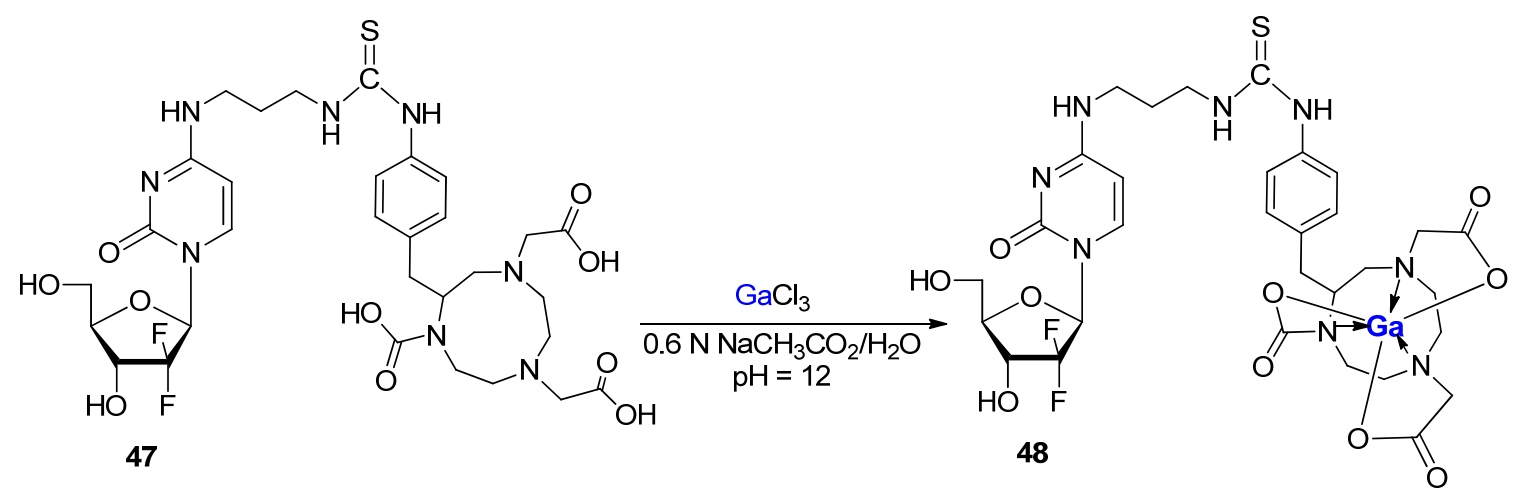

Scheme 33. Model labeling of NOTA-4- $N$-alkylgemcitabine conjugate with $\mathrm{GaCl}_{3}$.

\subsubsection{Synthesis of aliphatic side chain precursors for the 4-N-alkanoyl and 4-N- alkyl gemcitabine analogues.}

\subsubsection{Synthesis of the valproic acid derivatives.}

The treatment of commercially available diethyl diallylmalonate 49 with $\mathrm{KOH} / \mathrm{H}_{2} \mathrm{O}$ under reflux conditions afforded the double olefinic analogue 50. ${ }^{165}$ Fluorination of $\mathbf{5 0}$ with 70\% HF/pyridine (Olah's Reagent) gave the difluoro derivative $\mathbf{5 1}$ as a complex regioisomeric mixture (Scheme 34). ${ }^{166}$

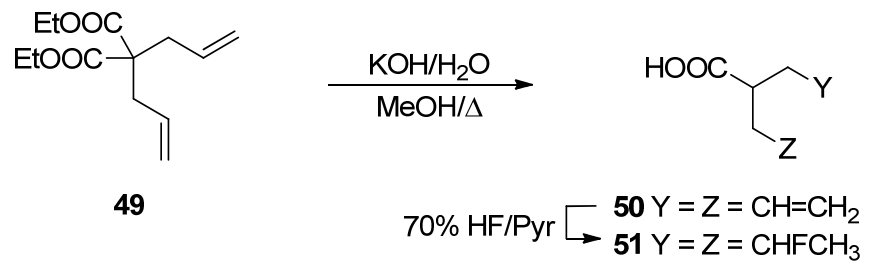

Scheme 34. Synthesis of diallylacetic acid and 4-Fluoro-2-(2-fluoropropyl)pentanoic acid Treatment of commercially available diethyl propylmalonate (52) with 3phenoxypropyl bromide in the presence of LDA (2M solution) afforded 53. Addition of $\mathrm{HBr}$ (aq.) resulted in de-esterification and de-carboxylation of ethyl ester and subsequent 
substitution of phenoxy function affording 54. Treatment of 54 with freshly distilled $\mathrm{SOCl}_{2}{ }^{167}$ gave the acyl chloride $\mathbf{5 5}$ (Scheme 35).

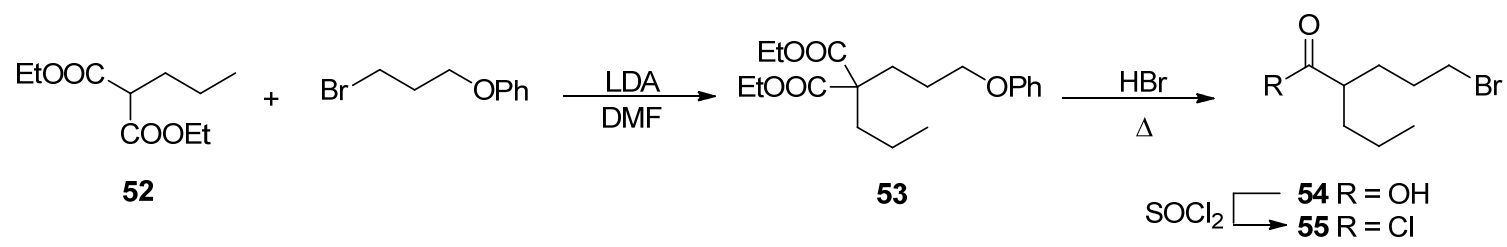

Scheme 35. Synthesis of 5-Bromo-2-propylpentanoyl chloride.

\subsubsection{Synthesis of the long chain carboxylic acid derivatives.}

Fluorination of commercially available undecylenic acid $\mathbf{5 6}$ with 70\% HF/pyr yielded a regioisomeric mixture of 10-fluoro, 9-fluoro, and 8-fluoro derivatives 57-59 with an isomeric ratio of 75:20:5 (Scheme 36). Although the use of pyridine is not ideal, the successful fluorination of the terminal olefin under the electrophilic addition conditions encourages development of these precursors for ${ }^{18} \mathrm{~F}$-labeling.<smiles>C=CCCCC(C)C(C(=O)O)C(=O)O</smiles>

Scheme 36. Synthesis of 10-fluoroundecanoic acid. Regioisomeric mixture contained $75 \%$ of the 10 -fluoro derivative, $20 \%$ of the 9 -fluoro derivative and $5 \%$ of the 8 fluoroderivative.

Esterification of the commercially available 11-bromoundecanoic acid $\mathbf{6 0}$ with $\mathrm{CH}_{2} \mathrm{~N}_{2} / \mathrm{MeOH}$ produced methyl ester $\mathbf{6 1} .^{151}$ The fluorination ${ }^{168}$ of $\mathbf{6 1}$ with TBAF $3 \mathrm{H}_{2} \mathrm{O}$ gave methyl 11-fluoroundecanoate $\mathbf{6 2}^{169}$ contaminated $(8 \%)$ by the elimination byproduct (methyl 10-undecenoate). Saponification of the $\mathbf{6 2}$ with $\mathrm{NaOH}$ yielded the carboxylic acid 63. Treatment of acid 60 with $\mathrm{SOCl}_{2}{ }^{167}$ afforded acyl chloride 64 (Scheme 37). 


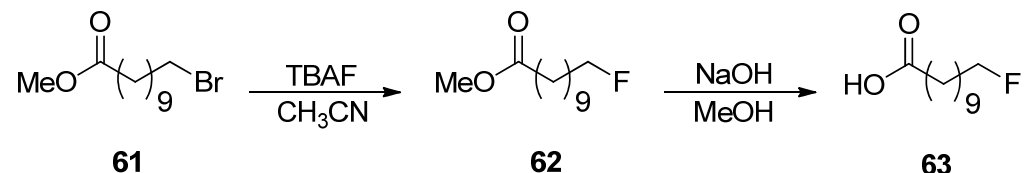
$\mathrm{CH}_{2} \mathrm{~N}_{2} \uparrow \mathrm{Et}_{2} \mathrm{O}$

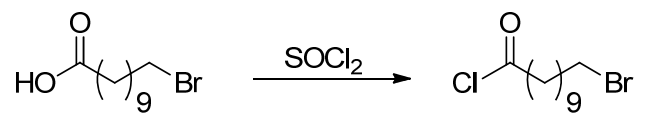

60

64

Scheme 37. Synthesis of 11-fluoroundecanoic acid and 11-bromoundecanoyl chloride.

\subsubsection{Synthesis of amino alcohol derivatives.}

Reduction of the commercially available 11 -aminoundecanoic acid $\mathbf{6 5}$ with $\mathrm{LiAlH}_{4}$ provided amino alcohol $66 .{ }^{170}$ Subsequent treatment of 66 with di-tert-butyl dicarbonate yielded the $N$-protected amino alcohol $67 .{ }^{170}$ Activation of the hydroxyl group of 67 with $\mathrm{MsCl}^{171}$ produced the mesylate $\mathbf{6 8}$ which upon treatment with benzyl alkoxide ${ }^{172}$ provided the fully protected amino alcohol 69. Selective $N$-deprotection of 69 with TFA/ $\mathrm{H}_{2} \mathrm{O}$ afforded the $O$-benzyl amino alcohol $\mathbf{7 0}$ (Scheme 38).

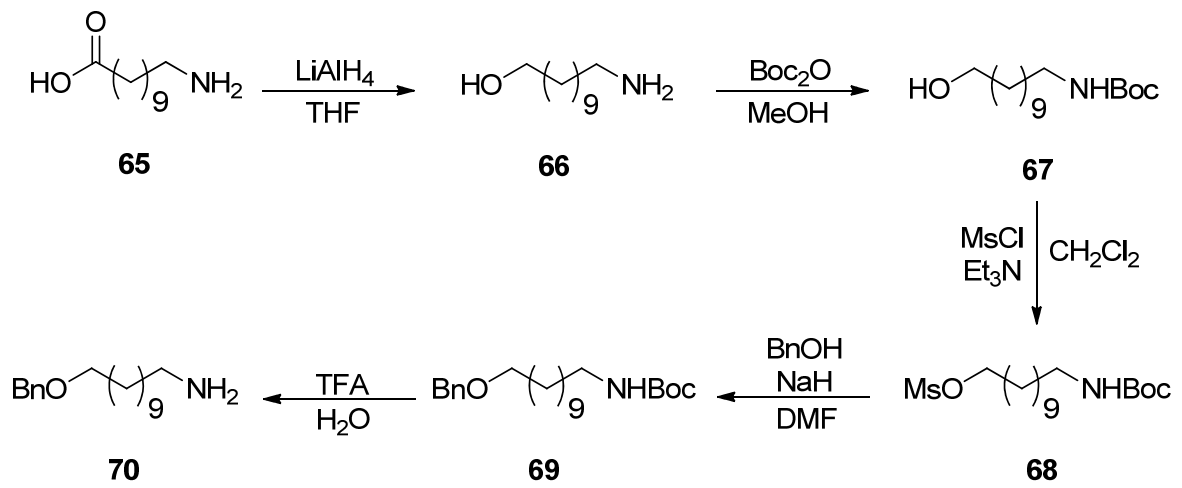

Scheme 38. Synthesis of 11-(benzyloxy)undecan-1-amine. 


\subsection{Biological evaluation of the 4-N-modified gemcitabine analogues.}

The 4-N-alkanoyl and 4- $N$-alkyl gemcitabine analogues were designed to exploit the resistance to deamination due to their respective 4- $N$-acyl and 4- $\mathrm{N}$-alkyl modifications. However, the pharmacokinetics of the parent metabolite is anticipated to be affected differently between the lipophilic 4- $\mathrm{N}$-alkanoyl and 4- $\mathrm{N}$-alkyl modification. The 4-Nalkyl modification is expected to be chemically and enzymatically resistant to cleavage, therefore having little to no release of $\mathrm{dFdC}$ and may potentially provide insight into the role the modification itself plays in the metabolism of the 4-N-modified analogues. As such, a preliminary biological evaluation was performed for 4- $N$-alkanoyl and 4- $N$-alkyl analogues to assess their relative activities and also to gauge the marketability of our analogues as potential chemotherapeutic agents.

\subsubsection{Preliminary cytostatic evaluation of $4-N$-modified gemcitabine analogues.}

The preliminary biological evaluation for the 4- $\mathrm{N}$-alkanoyl and 4- $\mathrm{N}$-alkyl gemcitabine derivatives was conducted by myself in the laboratory of Dr. Roy, from the Department of Environmental and Occupational Health at Florida International University.

\subsubsection{Cell viability and measurement of growth inhibition.}

Cytostatic activities of the 4- $N$-modified gemcitabine analogues were assessed after $72 \mathrm{~h}$ incubation period in breast adenocarcinoma MCF-7 cell line using sulforhodamine B (SRB) assay following established protocols. ${ }^{173}$ All compounds (purity $>95 \%$ ) were directly tested in free-base form, and were found to inhibit cell growth in a dose dependent manner as demonstrated by cytostatic activity curves in Figure 13. Absorbance estimates were used to evaluate percentage of cell growth versus analogue concentration to calculate $\mathrm{IC}_{50}$ values for selected analogues (Table 2). It should be pointed out that a 
difficulty encountered during this preliminary study was reproducibility of the activity values. The range of activity observed was substantially varied when attempting to repeat experiments at later dates. However, a persistent and recurring trend was observed with respect to activity between gemcitabine and all 4- $\mathrm{N}$-modified analogues.

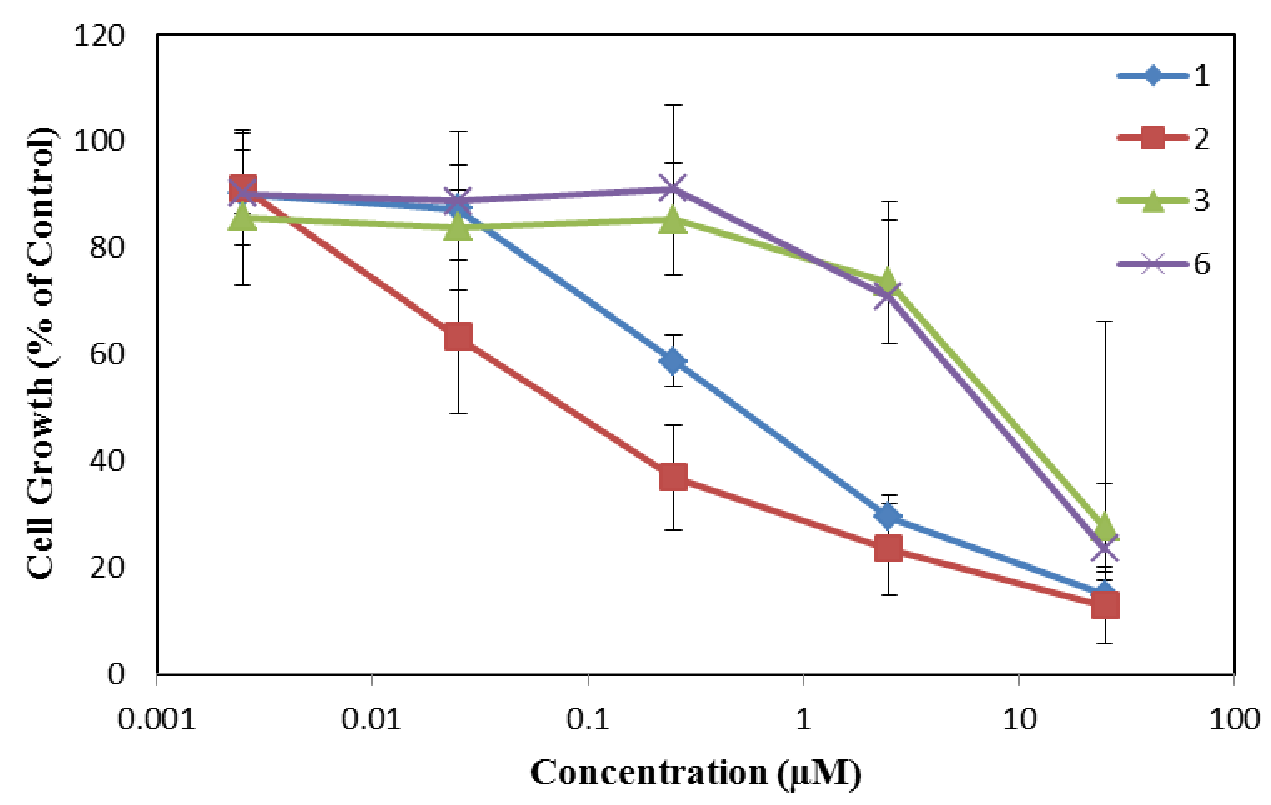

Figure 13. In vitro cytotoxicity curve of $4-N$-alkanoyl and 4- $N$-alkyl gemcitabine analogues on human tumor cell line MCF-7. Cells were treated with either gemcitabine (1), 4- $N$-nonenoylgemcitabine (4), 4- $N$-alkanoylgemcitabine (5), $4-N$-valproylgemcitabine (8) or 4- $\mathrm{N}$-alkylgemcitabine (26) at the indicated concentrations for $72 \mathrm{~h}$ before the viability of treated cells was determined by SRB assay. Results represent the mean of triplicates with error bars indicating standard deviation.

The 4- $N$-undecenoylgemcitabine $\mathbf{5}$ exhibited the most potent cytostatic activity with $\mathrm{IC}_{50}=0.2 \mu \mathrm{M}, 2.5$-fold more potent than observed with the parent drug $\mathbf{1}$ with $\mathrm{IC}_{50}=0.5$ $\mu \mathrm{M}$ in the MCF-7 cells. The di-olefinic 4- $N$-valproyl gemcitabine derivative $\mathbf{8}$, which is also a 4- $N$-alkanoyl gemcitabine derivative, demonstrated a diminished cytotoxic activity $\left(\mathrm{IC}_{50}=11.0 \mu \mathrm{M}\right)$ in comparison to the non-branched 5. Interestingly, the 4-Nalkylgemcitabine $26\left(\mathrm{IC}_{50}=6.5 \mu \mathrm{M}\right)$ exhibited activity comparable to 8 in MCF-7 cells. 
Table 2. In vitro cytotoxicity of representative $4-N$-modified gemcitabine analogues on human tumor cell line MCF-7.

\begin{tabular}{|cccc|}
\hline Cmpd. & $\mathrm{IC}_{50}(\mu \mathbf{M})$ & $\mathrm{IC}_{75}(\mu \mathbf{M})$ & $\mathrm{IC}_{90}(\mu \mathbf{M})$ \\
\hline $\mathbf{1}$ & $0.5 \pm 0.02^{b}$ & $4.4 \pm 0.08^{b}$ & $>25$ \\
\hline $\mathbf{5}$ & $0.2 \pm 0.01^{b}$ & $1.5 \pm 0.6$ & $16 \pm 2.5$ \\
\hline $\mathbf{8}$ & $11 \pm 7.0$ & $>25$ & $>25$ \\
\hline $\mathbf{2 6}$ & $6.5 \pm 3.2$ & $>25$ & $>25$ \\
\hline
\end{tabular}

${ }^{a}$ Cells were treated with either gemcitabine (1), 4- $N$-nonenoylgemcitabine (4), 4- $N$ alkanoylgemcitabine (5), 4- $N$-valproylgemcitabine (8) or 4-N-alkylgemcitabine (26) at the indicated concentrations for $72 \mathrm{~h}$ before the viability of treated cells was determined by SRB assay. Results represent the mean of triplicates with error bars indicating standard deviation. ${ }^{b}$ Statistical analysis (probability of difference of the treatment value from that of the nontreated control): $\mathrm{P}<0.05$.

During a preliminary evaluation comparing trends in cytostatic activities for the 4- $\mathrm{N}$ alkanoylgemcitabines (4-6), 4- $N$-nonenoylgemcitabine 4 with the shortest aliphatic side chain consistently exhibited less activity in comparison to 5 and $\mathbf{6}$ (Figure 14). These results however were insufficient to correlate cytostatic activity with the length of the side chain as reported by Immordino et al. ${ }^{63} \mathrm{~A}$ similar comparison between $4-\mathrm{N}$ alkanoylgemcitabines $(\mathbf{5}, \mathbf{1 3}, \mathbf{1 5}, \mathbf{1 8}$, and $\mathbf{2 1})$ with varying functional groups on the acyl chain was also explored (Figure 15). Again results were insufficient to correlate cytostatic activity with different terminal groups. However, in the evaluated set of compounds the 4- $\mathrm{N}$-fluoroalkanoyl gemcitabine analogue $\mathbf{1 3}$ appeared to be most active and the 4- $N$-hydroxyalkanoyl gemcitabine analogue 21 was consistently the least active in MCF-7 cells. 


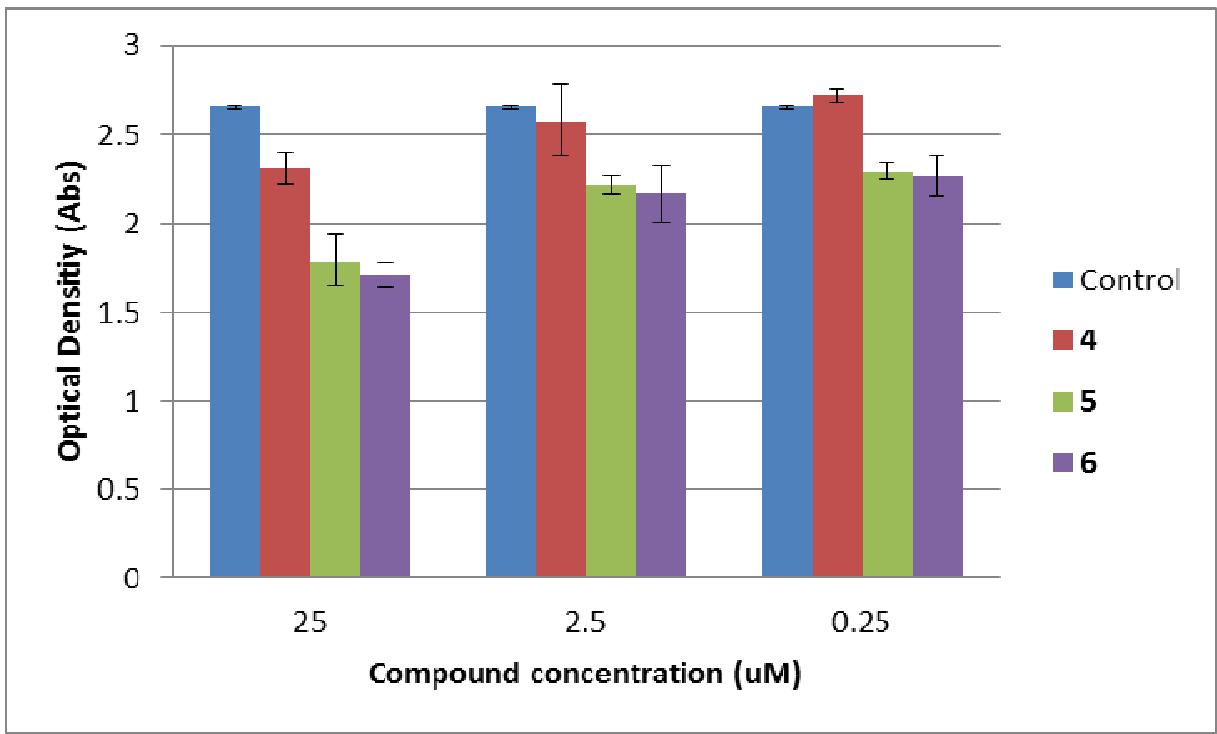

Figure 14. Effect of chain length on cytostatic activity of 4-N-alkanoylgemcitabines in MCF-7 cells. Cells were treated with either 4- $N$-nonenoylgemcitabine (4), 4- $N$ undecenoylgemcitabine (5), or 4-N-tridecenoylgemcitabine (6) at the indicated concentrations for $72 \mathrm{~h}$ before the viability of treated cells was determined by SRB assay. Results represent the mean of triplicates with error bars indicating standard deviation.

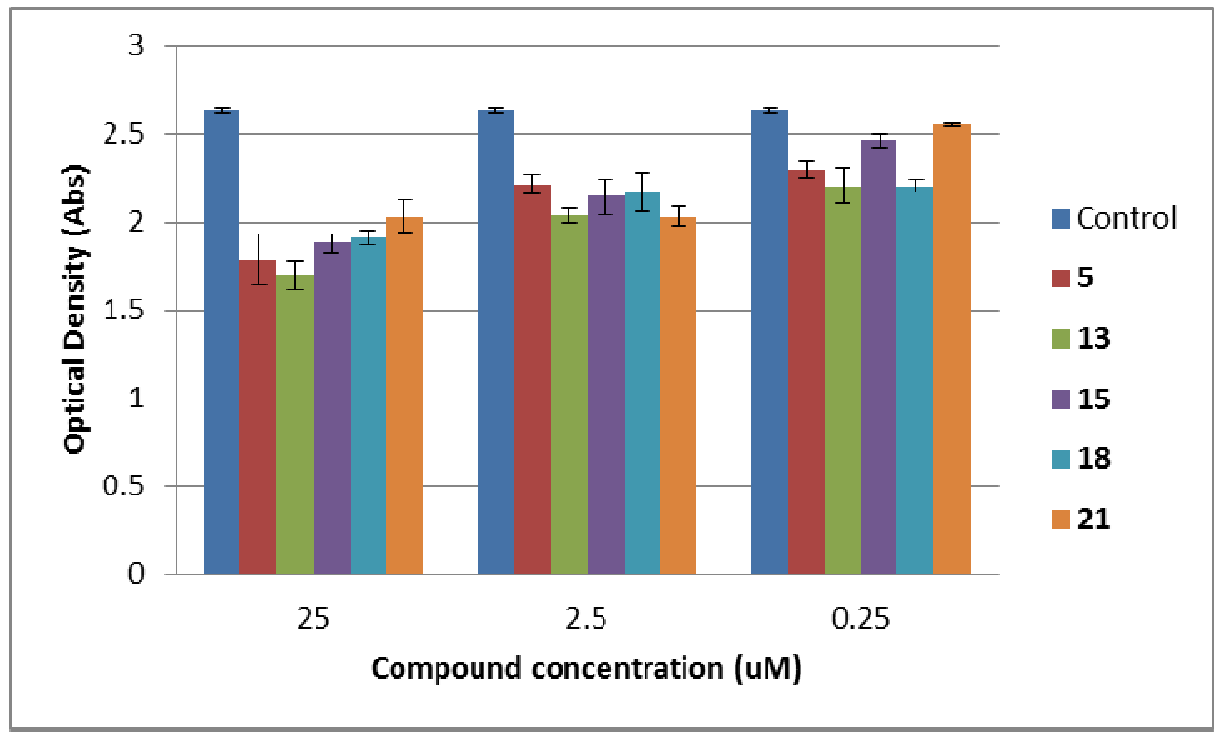

Figure 15. Effect of varying terminal groups on cytostatic activity of 4-Nalkanoylgemcitabines in MCF-7 cells. Cells were treated with either 4-Nundecenoylgemcitabine (5), 4- $\mathrm{N}$-fluoroundecenoylgemcitabine $\quad(\mathbf{1 3}), \quad 4-\mathrm{N}$ chloroundecenoylgemcitabine (15), 4- $\mathrm{N}$-bromoundecenoylgemcitabine (18), or 4- $\mathrm{N}$ hydroxyundecanoylgemcitabine (21) analogues at the indicated concentrations for $72 \mathrm{~h}$ before the viability of treated cells was determined by SRB assay. Results represent the mean of triplicates with error bars indicating standard deviation. 


\subsubsection{Anti-Proliferative Properties and Measurement of New DNA Synthesis}

To assess the mechanism by which the 4-N-modified gemcitabine analogues are inhibiting cell growth in the MCF-7 cell line, DNA proliferation was measured employing 5-bromodeoxyuridine (BrdU) assay. Results indicated that new DNA synthesis was being inhibited by the parent drug $\mathbf{1}$, the $4-N$-alkanoylgemcitabines $(\mathbf{5}, \mathbf{8})$ and the 4- $N$-alkylgemcitabine (26), indicating growth inhibition potentially being the result of more than cell death. At the higher test concentration $(25 \mu \mathrm{M})$, the $\mathbf{5}$ and $\mathbf{8}$ were of comparable anti-proliferative activity to the parent compound $\mathbf{1}$, whereas the $4-\mathrm{N}$ alkylgemcitabine $\mathbf{2 6}$ showed a less prominent capacity for inhibiting DNA synthesis (Figure 16). However at the lower test concentration $(2.5 \mu \mathrm{M})$, the $4-N-$ alkanoylgemcitabine $\mathbf{5}$ demonstrated superior anti-proliferative activity, whereas analogues $\mathbf{8}$ and $\mathbf{2 6}$ were both found to be comparable to $\mathbf{1}$ in the MCF-7 cells (Figure 17). Interestingly, compounds demonstrated varying progressions with time in inhibiting DNA synthesis, indicating different pharmacokinetics or stabilities between the compounds under biological conditions. 


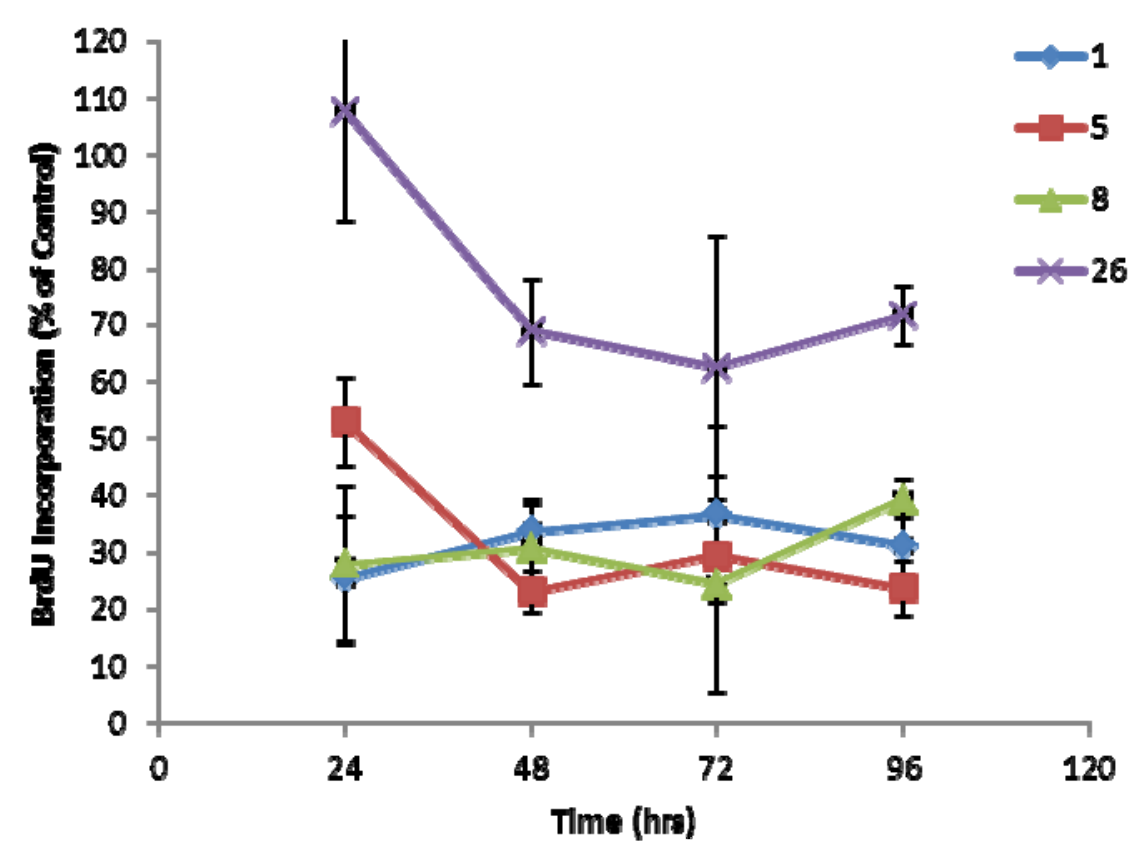

Figure 16. Cell proliferation time-point measurement study for $25 \mu \mathrm{M}$ treatment of representative 4- $\mathrm{N}$-modified gemcitabine analogues on MCF-7 cell line. Cells were treated with either gemcitabine (1), 4- $\mathrm{N}$-nonenoylgemcitabine (4),4- $\mathrm{N}$ alkanoylgemcitabine (5), 4- $\mathrm{N}$-valproylgemcitabine (8) or 4- $\mathrm{N}$-alkylgemcitabine (26) at the indicated $25 \mu \mathrm{M}$ treatment and cell proliferation of treated cells was determined by BrdU assay at 24, 48, 72 and $96 \mathrm{~h}$ time periods. Results represent the mean of triplicates with error bars indicating standard deviation. 


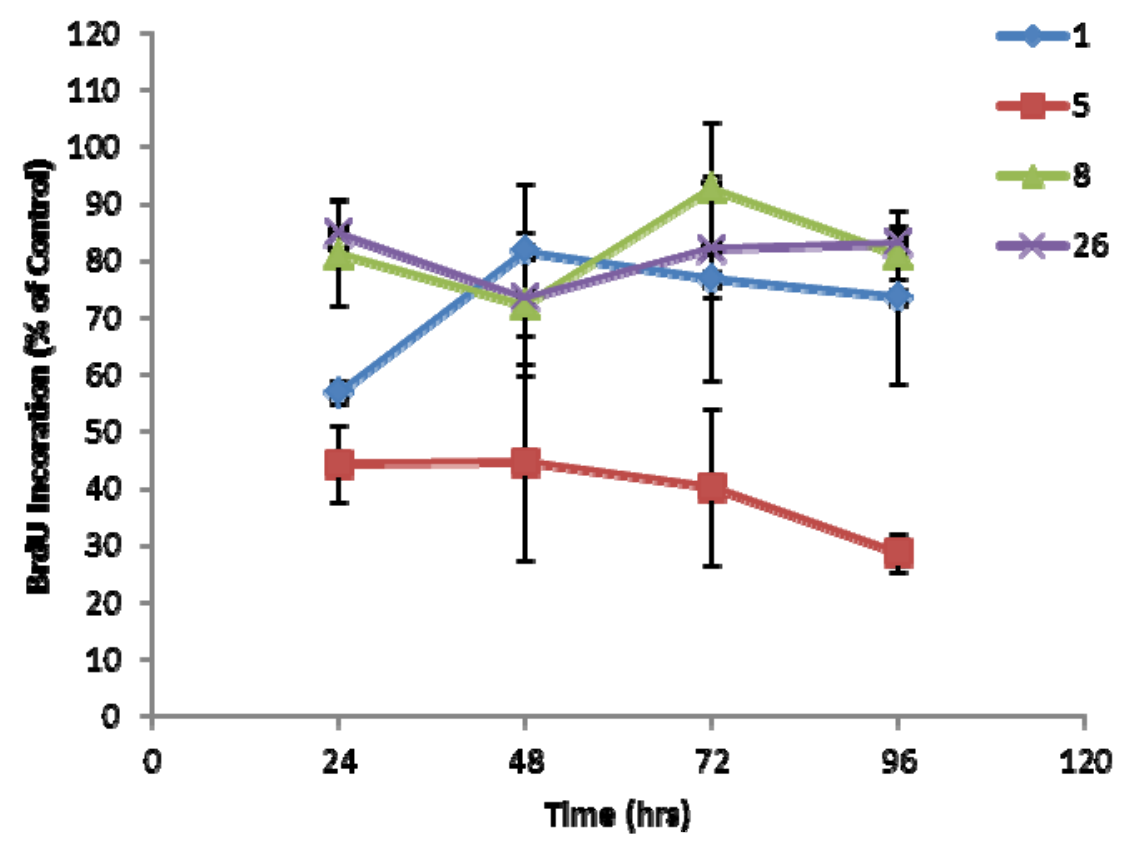

Figure 17. Cell proliferation time-point measurement study for $2.5 \mu \mathrm{M}$ treatment of representative $4-\mathrm{N}$-modified gemcitabine analogues on MCF-7 cell line. Cells were treated with either gemcitabine (1), 4- $N$-nonenoylgemcitabine (4),4- $N$ alkanoylgemcitabine (5), 4- $N$-valproylgemcitabine (8) or 4- $N$-alkylgemcitabine (26) at the indicated $2.5 \mu \mathrm{M}$ treatment and cell proliferation of treated cells was determined by BrdU assay at 24, 48, 72 and $96 \mathrm{~h}$ time periods. Results represent the mean of triplicates with error bars indicating standard deviation.

\subsubsection{Cell Cycle Analysis}

The observed inhibition of new DNA synthesis however does not indicate a stage specific cell cycle perturbation, nor give direct evidence of apoptosis. Cell cycle analysis by flow cytometry with propidium iodide (PI) staining was therefore evaluated for selected analogues $(\mathbf{1}, \mathbf{5}, \mathbf{8}, \mathbf{2 6})$ in MCF-7 cells at the $25 \mu \mathrm{M}$ test concentration. Cells were analyzed after a $48 \mathrm{~h}$ incubation period and statistics generated by FCS Express 4 Flow program. As evident by given values in Table 3 and histograms in Figure 18, for all compounds tested there was a significant reduction in S-phase and accumulation in $\mathrm{G}_{0} / \mathrm{G}_{1}$, as well as noticeable decline of cells in $\mathrm{G}_{2} / \mathrm{M}$, after the $48 \mathrm{~h}$ incubation period in MCF-7 cells. A reduced progression of the cell cycle therefore was observed for all 
compounds, consistent with preliminary results from the cell viability and proliferation studies. These results may have be attributed to cell cycle freezing at this high test concentration prior to a $\mathrm{G}_{2} / \mathrm{M}$ block occurring, a phenomenon reported in studies detailing cell cycle effect of gemcitabine in ovarian carcinomas. ${ }^{174}$ However studies by Ali et al. ${ }^{175}$ characterizing effects of gemcitabine at lower concentration in MCF-7 cells yielded similar results after a $48 \mathrm{hr}$ incubation period.

Table 3. Cell cycle analysis of 4-N-modified gemcitabine analogue treated human tumor cell line MCF-7 by flow cytometry.

\begin{tabular}{|cccccccccc|} 
Cmpd. & $\mathrm{G}_{1}$ Mean & $\mathrm{G}_{1} \mathrm{CV}$ & $\%_{\mathrm{G}_{1}}$ & $\mathrm{G} 2$ Mean & $\mathrm{G}_{2} \mathrm{CV}$ & $\% \mathrm{G}_{2}$ & $\% \mathrm{~S}$ & $\mathrm{G}_{2} / \mathrm{G}_{1}$ & $\mathrm{BAD}$ \\
\hline Cntrl. & 4784624 & 6.74 & 51.8 & 9635017 & 6.7 & 15.1 & 33.2 & 2.12 & 1.19 \\
\hline $\mathbf{1}$ & 5281140 & 9.45 & 78.9 & 10342718 & 9.6 & 11.8 & 9.3 & 2.12 & 0.93 \\
\hline $\mathbf{5}$ & 5359904 & 9.15 & 80.8 & 10882586 & 7.7 & 10.9 & 8.4 & 2.12 & 0.59 \\
\hline $\mathbf{8}$ & 5149490 & 10.47 & 81.8 & 10473201 & 10.47 & 10.18 & 8.0 & 2.12 & 0.07 \\
\hline $\mathbf{2 6}$ & 5063732 & 8.42 & 77.6 & 10226335 & 8.42 & 12.0 & 10.3 & 2.12 & 0.17 \\
\hline
\end{tabular}

${ }^{a} \mathrm{Cells}$ were treated with either gemcitabine (1), 4- $\mathrm{N}$-nonenoylgemcitabine (4), 4- $\mathrm{N}$ alkanoylgemcitabine (5), 4- $\mathrm{N}$-valproylgemcitabine (8) or 4- $\mathrm{N}$-alkylgemcitabine (26) and the cell cycle analyzed after $48 \mathrm{~h}$ by flow cytometry using propidium iodide staining. 


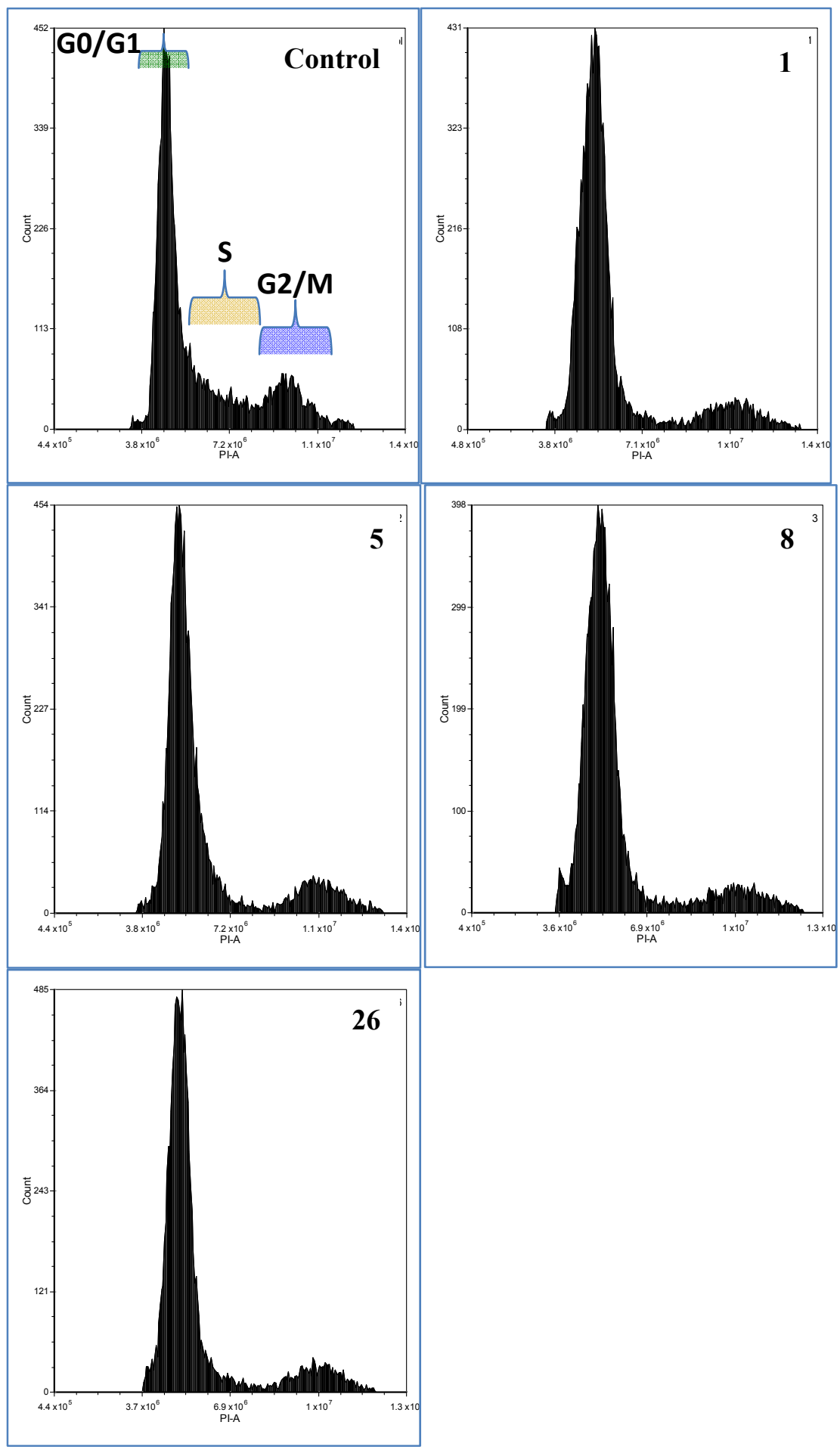

Figure 18. DNA Histograms of MCF-7 cells after $25 \mu \mathrm{M}$ treatment of compound. Cells were treated with either gemcitabine (1), 4- $N$-nonenoylgemcitabine (4), 4- $N$ alkanoylgemcitabine (5), 4- $N$-valproylgemcitabine (8) or 4- $N$-alkylgemcitabine (26) and 
the cell cycle analyzed after $48 \mathrm{~h}$ by flow cytometry using propidium iodide staining. Cell phases indicated on panel labeled control.

\subsubsection{Cytostatic evaluation of the $4-N$-modified gemcitabine analogues.}

Further collaborative opportunites with Dr. Cheppail Ramachandran, from the department of Radiation Oncology at University of Miami's School of medicine, and with Dr. Jan Balzarini, from the Rega Institute for Medical Research, were explored to refine and characterize the cytostatic activities of the 4-N-alkanoyl and 4- $\mathrm{N}$-alkyl gemcitabine analogues, with each contributing interesting and valuable new information.

\subsubsection{Cytostatic evaluation of 4- $N$-modified gemcitabine analogues in Panc- 1 cells.}

The Ramachandran group evaluated select 4- $\mathrm{N}$-alkanoyl $(\mathbf{5}, \mathbf{7 - 9})$ and 4-N-alkyl

$(\mathbf{2 6}, \mathbf{2 7})$ gemcitabine analogues in human pancreatic cancer Panc-1 cell line after $72 \mathrm{~h}$ incubation using a Cell Proliferation kit I (MTT), from Roche Biochemicals. The results from this study (Table 4) suggested a much larger margin between activities originally observed in the preliminary screening (reference Table 2) between gemcitabine 1 with $\mathrm{IC}_{50}=0.08 \mu \mathrm{g} / \mathrm{mL}\left(\mathrm{IC}_{50}=0.3 \mu \mathrm{M}\right)$ and the $4-N$-alkanoyl and $4-N$-alkyl gemcitabine analogues. These results were of particular significance as they also suggested both the aliphatic 4- $N$-alkanoyl and 4- $N$-alkyl gemcitabine analogues may be more active than gemcitabine in Panc-1 cells, showing a capacity for overcoming the parent drugs inability to achieve $\mathrm{IC}_{75}$ and $\mathrm{IC}_{90}$ values at relatively low doses. The 4- $N$-alkylgemcitabines 26 and 27, with $\mathrm{IC}_{50}=35 \mu \mathrm{g} / \mathrm{mL}(84 \mu \mathrm{M})$ and $\mathrm{IC}_{50}=44 \mu \mathrm{g} / \mathrm{mL}(101 \mu \mathrm{M})$, respectively, demonstrated more potent cytostatic activities in Panc-1 cells in comparison to the 4- $\mathrm{N}$ alkanoylgemcitabine counterparts 5 and 9, with $\mathrm{IC}_{50}=124 \mu \mathrm{g} / \mathrm{mL}(289 \mu \mathrm{M})$ and $\mathrm{IC}_{50}=$ $129 \mu \mathrm{g} / \mathrm{mL}(287 \mu \mathrm{M})$ respectively. These finding are the first observed example of $4-N$ alkylgemcitabine derivatives exhibiting superior activity in comparison to 4- $\mathrm{N}$ - 
alkanoylgemcitabine derivatives. The branched $4-N$-valproyl gemcitabines $\mathbf{7}$ and $\mathbf{8}$ failed to achieve $\mathrm{IC}_{50}$ values within the range of tested concentrations.

Table 4. In vitro cytostatic activity of representative 4- $\mathrm{N}$-modified gemcitabine analogues on human tumor cell line Panc-1.

\begin{tabular}{|cccc|}
\hline Cmpd. & $\mathrm{IC}_{50}(\mu \mathrm{gg} / \mathrm{mL})$ & $\mathrm{IC}_{75}(\mu \mathrm{gg} / \mathrm{mL})$ & $\mathrm{IC}_{90}(\mu \mathrm{g} / \mathrm{mL})$ \\
\hline $\mathbf{1}$ & $0.08 \pm 0.02^{d}$ & $>200$ & $>200$ \\
\hline $\mathbf{5}$ & $124 \pm 5^{d}$ & $167 \pm 10^{c}$ & $>200$ \\
\hline $\mathbf{7}^{a}$ & $>200$ & $>200$ & $>200$ \\
\hline $\mathbf{8}$ & $>200$ & $>200$ & $>200$ \\
\hline $\mathbf{9}$ & $129 \pm 11^{d}$ & $>200$ & $>200$ \\
\hline $\mathbf{2 6}$ & $35 \pm 4^{d}$ & $44 \pm 5^{c}$ & $50 \pm 2$ \\
\hline $\mathbf{2 7}$ & $44 \pm 6^{d}$ & $72 \pm 7^{c}$ & $93 \pm 15$ \\
\hline
\end{tabular}

${ }^{a}$ LY2334737 (2) In free-base form. ${ }^{b}$ Cells were treated with either gemcitabine (1), $4-N$ alkanoylgemcitabines (5 or 9), 4- $N$-valproylgemcitabines $(\mathbf{8}$ or 9) or 4-Nalkylgemcitabines (26 or 27) over a range of concentrations and incubated for $72 \mathrm{~h}$ before the viability of treated cells was determined by MTT assay. Results represent the mean of triplicates with error bars indicating standard deviation. ${ }^{c}$ Statistical analysis (probability of difference of the treatment value from that of the nontreated control): $\mathrm{P}<0.05$. ${ }^{d}$ Statistical analysis (probability of difference of the treatment value from that of the nontreated control): $\mathrm{P}<0.001$.

\subsubsection{Cytostatic evaluation of $4-N$-modified gemcitabine analogues in human tumor cell line panel}

The Balzarini group evaluated select $4-N$-alkanoyl $(3-6,7,13,21)$ and $4-N$-alkyl

$(\mathbf{2 6}, \mathbf{3 1}, \mathbf{3 9})$ gemcitabine analogues on a panel of murine and human tumor cell lines, including the dCK-deficient $\mathrm{CEM} / \mathrm{dCK}^{-}$cell line (Table 5). ${ }^{176}$ These findings demonstrated a more varied difference in potency between gemcitabine, the 4-N-alkanoyl and the 4-N-alkyl gemcitabine derivatives than observed in the prior screenings (reference tables 2 and 4). Overall, the $4-N$-alkanoylgemcitabines performed as expected, likely behaving as pro-drugs of gemcitabine. ${ }^{149}$ Potent antiproliferative activities were observed for 4- $N$-alkanoylgemcitabines 3-6, 13 and 21 boasting $\mathrm{IC}_{50}$ values in the low $\mathrm{nM}$ range comparable to gemcitabine. The branched $4-\mathrm{N}$-valproylgemcitabine 7 , tested in it's free-base form, had $\mathrm{IC}_{50}$ values in the low $\mu \mathrm{M}$ range more comparable to the 4-N- 
alkylgemcitabines than to the other 4- $N$-alkanoyl derivatives. The observed cytostatic activities for $\mathbf{7}$ (compound $\mathbf{2}$ in free base form) are consistent with findings reported by Pratt et al., who described $\mathrm{IC}_{50}$ values for 7 being " 80 -fold more" less potent compared to $\mathbf{1}$ on the NCI-60 DTP human tumor cell line panel. ${ }^{71}$ The $4-N$-alkylgemcitabines $\mathbf{2 6}, 31$ and 39 possessed very modest cytostatic activites, with $\mathrm{IC}_{50}$ values in the low $\mu \mathrm{M}$ range (Table 5). Although a trend was not observed, cytostatic activities again appeared to vary only slightly between compounds with different chain lengths. Also consistent with the preliminary screen was the slight variation in activities between 4- $\mathrm{N}$ alkanoylgemcitabines bearing different functional groups on the terminal end of the aliphatic side chain.

As anticipated, the cytostatic activities for all $4-N$-alkanoylgemcitabines $(\mathbf{3}-7, \mathbf{1 3}, \mathbf{2 1})$ were severely reduced, by nearly two orders of magnitude, in the dCK-deficient $\mathrm{CEM} / \mathrm{dCK}^{-}$cell line. These findings validate the proposed role dCK plays in the metabolism of these compounds, where the 4- $N$-alkanoylgemcitabines first need to be converted to gemcitabine before achieving their cytostatic potential. ${ }^{60}$ However, cytostatic activities of the $4-N$-alkylgemcitabines $(\mathbf{2 6}, \mathbf{3 1}$, and 39) were only reduced by approximately 2-5 times in the dCK-deficient $\mathrm{CEM} / \mathrm{dCK}^{-}$cells, suggesting some role for $\mathrm{dCK}$ in the metabolism of the 4- $\mathrm{N}$-alkylgemcitabines.

Although the Panc-1 cell line was not evaluated in the study by Balzarini, it is still worthy to note that the 4-N-alkanoyl and 4- $N$-alkyl gemcitabine analogues demonstrated a significant difference in their range of cytotoxic activity. Comparing to results from the preliminary screening (Table 2) and also from the Ramachandran group (Table 4), the aliphatic 4- $N$-alkanoylgemcitabines of similar structure to $\mathbf{5}$ were drastically more potent 
than the branched 4-N-valproylgemcitabine 7 and the 4 - $N$-alkylgemcitabine 26 . Interestingly, the observed activity for the 4-N-alkylgemcitabine 26 in MCF-7 cells during the Balzarini group's study was near to the described value from the preliminary cytostatic evaluation (reference Table 1).

Table 5. In vitro cytotoxicity of representative 4- $N$-modified analogues on a panel of murine and human tumor cell lines. ${ }^{176}$

\begin{tabular}{|cccccc|} 
Cmpd. & $\mathbf{L 1 2 1 0}$ & $\mathbf{C E M} / \mathbf{0}$ & $\mathbf{C E M} / \mathbf{d C K}-$ & HeLa & MCF-7 \\
\hline $\mathbf{1}$ & $0.013 \pm 0.001$ & $0.069 \pm 0.002$ & $7.6 \pm 0.5$ & $0.0099 \pm 0.0041$ & $0.0072 \pm 0.0002$ \\
\hline $\mathbf{3}$ & $0.014 \pm 0.002$ & $0.060 \pm 0.012$ & $5.8 \pm 0.5$ & $0.0089 \pm 0.0024$ & $0.0053 \pm 0.0023$ \\
\hline $\mathbf{4}$ & $0.024 \pm 0.017$ & $0.14 \pm 0.00$ & $20 \pm 2$ & $0.042 \pm 0.005$ & $0.0079 \pm 0.0002$ \\
\hline $\mathbf{5}$ & $0.018 \pm 0.016$ & $0.071 \pm 0.015$ & $12 \pm 9$ & $0.012 \pm 0.007$ & $0.0062 \pm 0.0029$ \\
\hline $\mathbf{6}$ & $0.021 \pm 0.018$ & $0.069 \pm 0.002$ & $6.8 \pm 1.8$ & $0.013 \pm 0.007$ & $0.0079 \pm 0.0012$ \\
\hline $\mathbf{7}^{\boldsymbol{a}}$ & $1.1 \pm 0.7$ & $5.2 \pm 2.3$ & $161 \pm 8$ & $0.76 \pm 0.30$ & $0.55 \pm 0.49$ \\
\hline $\mathbf{1 3}$ & $0.053 \pm 0.040$ & $0.059 \pm 0.009$ & $7.2 \pm 0.8$ & $0.011 \pm 0.004$ & $0.0077 \pm 0.0006$ \\
\hline $\mathbf{2 1}$ & $0.023 \pm 0.003$ & $0.24 \pm 0.19$ & $19 \pm 6$ & $0.049 \pm 0.030$ & $0.0081 \pm 0.0005$ \\
\hline $\mathbf{2 6}$ & $7.0 \pm 3.0$ & $13 \pm 6$ & $60 \pm 15$ & $3.4 \pm 0.0$ & $28 \pm 14$ \\
\hline $\mathbf{3 1}$ & $29 \pm 11$ & $86 \pm 10$ & $140 \pm 28$ & $22 \pm 4$ & $27 \pm 3$ \\
\hline $\mathbf{3 9}$ & $28 \pm 2$ & $28 \pm 4$ & $134 \pm 18$ & $17 \pm 4$ & $26 \pm 7$ \\
\hline
\end{tabular}

${ }^{a}$ LY2334737 (2) In free-base form. ${ }^{b}$ Cells were treated with either gemcitabine (1), 4- $N$ alkanoylgemcitabines $(\mathbf{3}, \mathbf{4}, \mathbf{5}, \mathbf{6}, 13$ or 21), 4- $N$-valproylgemcitabines (7) or 4- $N$ alkylgemcitabines $(\mathbf{2 2}, \mathbf{2 6}, \mathbf{3 1}$ or 39) over a range of concentrations and incubated for 72 $\mathrm{h}$ before the viability of treated cells was determined by Coulter counter.

Select compounds $(\mathbf{5}, \mathbf{2 1}, \mathbf{2 6}, \mathbf{3 1})$ were also evaluated for potential interactions with mitochondrial $\mathrm{TK}-2$ and cytosolic $\mathrm{dCK}$ and also as direct substrates for $\mathrm{dCK}{ }^{176}$ Incubation with the selected compounds showed no observable inhibition of phosphorylation for deoxycytidine by $\mathrm{dCK}$ or for deoxythymidine by TK-2. Compounds 5 and 21 had very little $(<1 \%)$ substrate activity with $\mathrm{dCK}$, consistent with $\mathrm{CEM} / \mathrm{dCK}$ cell line findings. The observed reduction in activity in the $\mathrm{dCK}$ - cell line reaffirms the 
hypothesis that the 4- $\mathrm{N}$-alkanoylgemcitabines first need to be converted to gemcitabine before acting as substrates for $\mathrm{dCK}$. On the other hand, even under conditions which phosphorylate gemcitabine by $15 \%$, neither $\mathbf{2 6}$ nor $\mathbf{3 1}$ had any measurable substrate activity with dCK. Taken together with the marked loss in cytostatic activity in the CEM/dCK- cells, it is possible that the observed activity for the 4- $N$-alkylgemcitabines may be achieved via a dCK-independent pathway. However these findings do not exclude, at least in some part, the cytostatic activities being attributed to a poor cellular uptake of the 4- $\mathrm{N}$-alkylgemcitabines or a poor, if any, conversion to the parent drug $\mathbf{1}$ which falls outside the assay detection limits $(<1 \%)$.

To gain further insight into metabolism of these analogues, stability and resistance to enzymatic deamination were evaluated for 4- $\mathrm{N}$-alkanoylgemcitabine 21 and $4-\mathrm{N}$ alkylgemcitabine $\mathbf{3 1}$ in parallel with gemcitabine by incubating each separately with human serum and murine liver extracts (Figure 19). ${ }^{176}$ Analysis by HPLC showed that gemcitabine was measurably deaminated as a function of time to its inactive uracil derivative $\mathrm{dFdU}$ in $50 \%$ human serum (panel A). As predicted, the 4- $\mathrm{N}$ alkanoylgemcitabine prodrug $\mathbf{2 1}$ was observed to gradually undergo conversion to gemcitabine, which after prolonged exposure was further deaminated to dFdU (panel B). However, the 4- $\mathrm{N}$-alkylgemcitabine $\mathbf{3 1}$ was neither observed to be directly deaminated nor was there any measurable conversion to gemcitabine (panel C). Incubation of $\mathbf{2 1}$ with murine liver extract gave evidence for a rapid conversion of the 4- $N$-alkanoylgemcitabine to gemcitabine (and dFdU). Parallel incubation of $\mathbf{3 1}$ with murine liver extract revealed that the 4- $\mathrm{N}$-alkylgemcitabine remained stable for at least 2 hours (Figure 20). These findings again favor the hypothesis that the considerable difference in cytostatic activities 
between the 4-N-alkanoylgemcitabine $\mathbf{2 1}$ and the $4-N$-alkylgemcitabine $\mathbf{3 1}$ is attributed to their respective enzymatic conversion, or lack thereof, to gemcitabine. Although the mechanism of action for the antiproliferative activity of the 4- $\mathrm{N}$-alkylgemcitabines remains unclear, it might well be different than the cellular targets for the $4-\mathrm{N}$ alkanoylgemcitabines. 


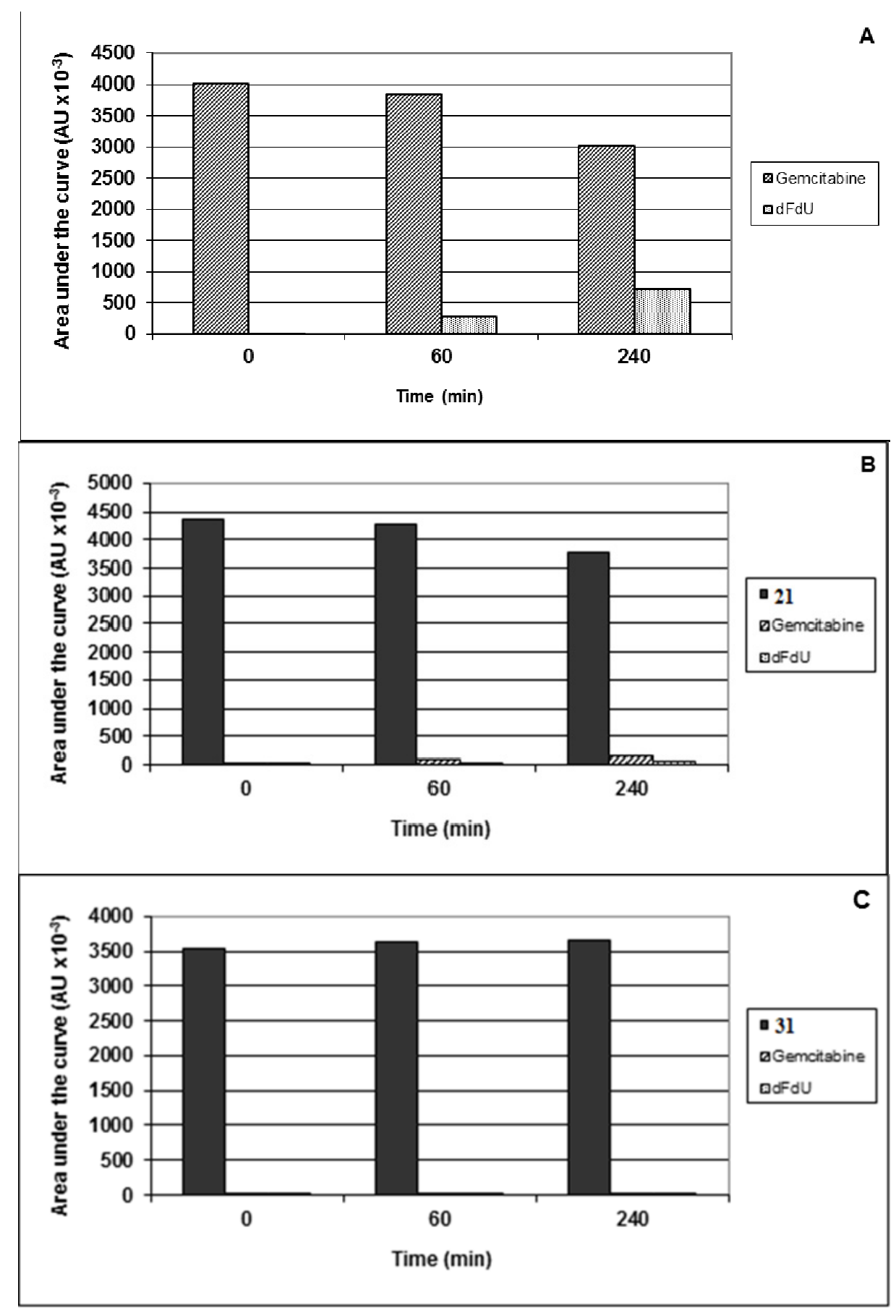

Figure 19. Time-dependent evaluation of the stability and resistance to deamination for gemcitabine (A), 4-N-alkanoylgemcitabine 21 (B) and 4-N-alkylgemcitabine 31 (C) in $50 \%$ human serum in PBS. ${ }^{176}$ 


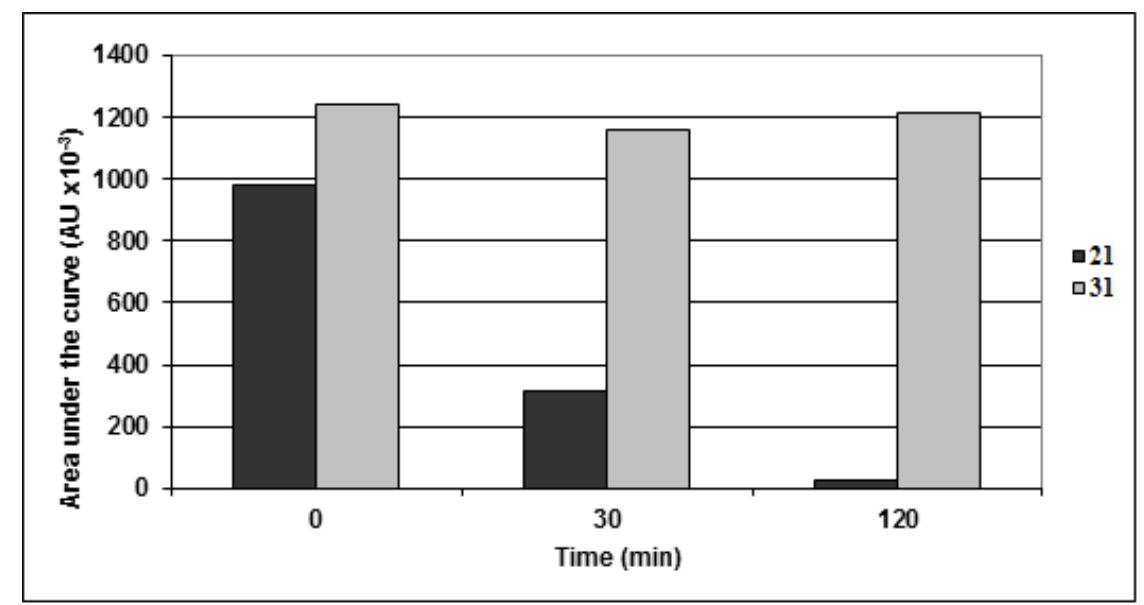

Figure 20. Time-dependent evaluation of the stability of 4- $N$-alkanoylgemcitabine 21 and $4-N$-alkylgemcitabine $\mathbf{3 1}$ in murine liver extract in PBS. ${ }^{176}$

\subsection{Synthesis and characterization of $\left[{ }^{18} \mathrm{~F}\right]-$ and $\left[{ }^{68} \mathrm{Ga}\right]-4-\mathrm{N}$-alkylgemcitabine radioligands.}

The developed chemistry for model fluorination and chelation studies with KF and $\mathrm{GaCl}_{3}$ has facilitated radiosynthesis of the $\left[{ }^{18} \mathrm{~F}\right]-4-N$-alkylgemcitabine 39 and $\left[{ }^{68} \mathrm{Ga}\right]-4-N$ alkylgemcitabine-NOTA conjugate 48. Radiosynthesis and in-vivo evaluation of $\left[{ }^{18} \mathrm{~F}\right]-4-$ $\mathrm{N}$-alkylgemcitabine radioligand $\mathbf{3 9}$ were performed in the laboratory of Dr. Caius Radu, from the Crump Institute for Molecular Imaging. The radiosynthetic evaluation of the $\left[{ }^{68} \mathrm{Ga}\right]-4-N$-alkylgemcitabine-NOTA conjugate $\mathbf{4 8}$ was conducted in the laboratory of Dr. Anthony McGoron, from the Department of Biomedical Engineering in FIU.

\subsection{1. $\left[{ }^{18} \mathrm{~F}\right]$-Labeling and evaluation of the $\left[{ }^{18} \mathrm{~F}\right]-4-\mathrm{N}$-alkylgemctiabine radioligand.}

To observe the distribution of $\mathbf{3 9}$ in vivo, $70 \mu \mathrm{Ci}$ of the probe was injected via tail vein into non-tumor bearing and tumor bearing mice (individual mice indicated by serial code numbers, Figures 21-24). The specimens were imaged after $1 \mathrm{~h}$, first by positron emission tomography and then computed tomography, and the images analyzed in combination using Osirix software. Imaging data was expressed as the injected dose per 
gram percentage $(\% \mathrm{ID} / \mathrm{g})$ with the injected dose, time, decay and body weight all taken into consideration. Initial findings with $\left[{ }^{18} \mathrm{~F}\right]-4-N$-fluoroalkylgemcitabine 39 indicated a dCK-specific accumulation in the spleen, with signal present in the dCK wild-type mice and absent in the deoxycytidine kinase knock-out (dCK KO) mice (Figure 21). The dCKspecific accumulation suggests a possible dCK-independent pathway consistent with earlier results from the observed activities in the dCK deficient cell line. The observed accumulation of signal in the bone appears to be $\mathrm{dCK}$-independent and attributed to in vivo defluorination of the probe, whereby free $\left[{ }^{18} \mathrm{~F}\right]^{-}$is released via elimination type mechanism. The time-point evaluation of the $\left[{ }^{18} \mathrm{~F}\right]-4-\mathrm{N}$-fluoroalkylgemcitabine probe over a $3 \mathrm{~h}$ period in the dCK wild-type mice (Figure 22) and the dCK KO mice (Figure 23) was also explored. Evaluation of the probe over the time course supported the proposed in vivo defluorination, with a gradual reduction of signal observed in the spleen, gallbladder and other organs accompanied by an accumulation of signal in the bone over the $3 \mathrm{~h}$ period.

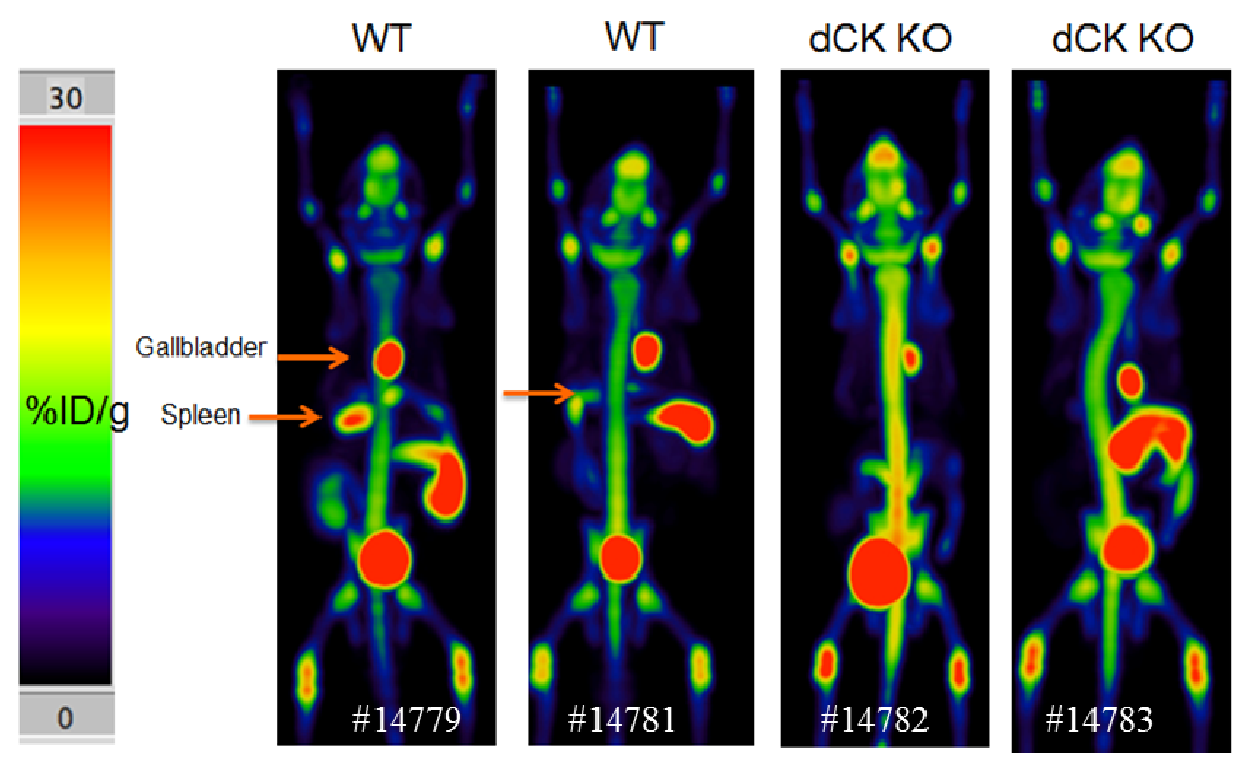

Figure 21. Uptake of $\left[{ }^{18} \mathrm{~F}\right]-4-N$-fluoroalkylgemcitabine in dCK WT and KO mice. 


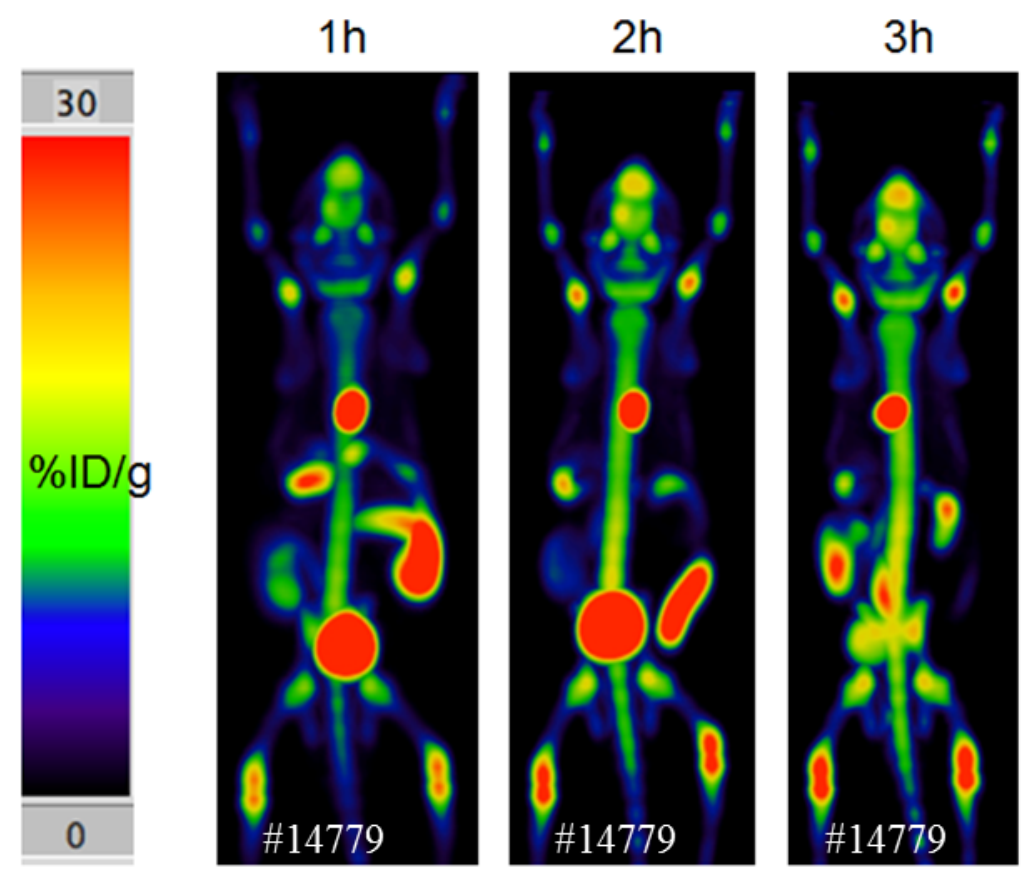

Figure 22. Time-dependent study for $\left[{ }^{18} \mathrm{~F}\right]-4-N$-fluoroalkylgemcitabine uptake in dCK WT mice.

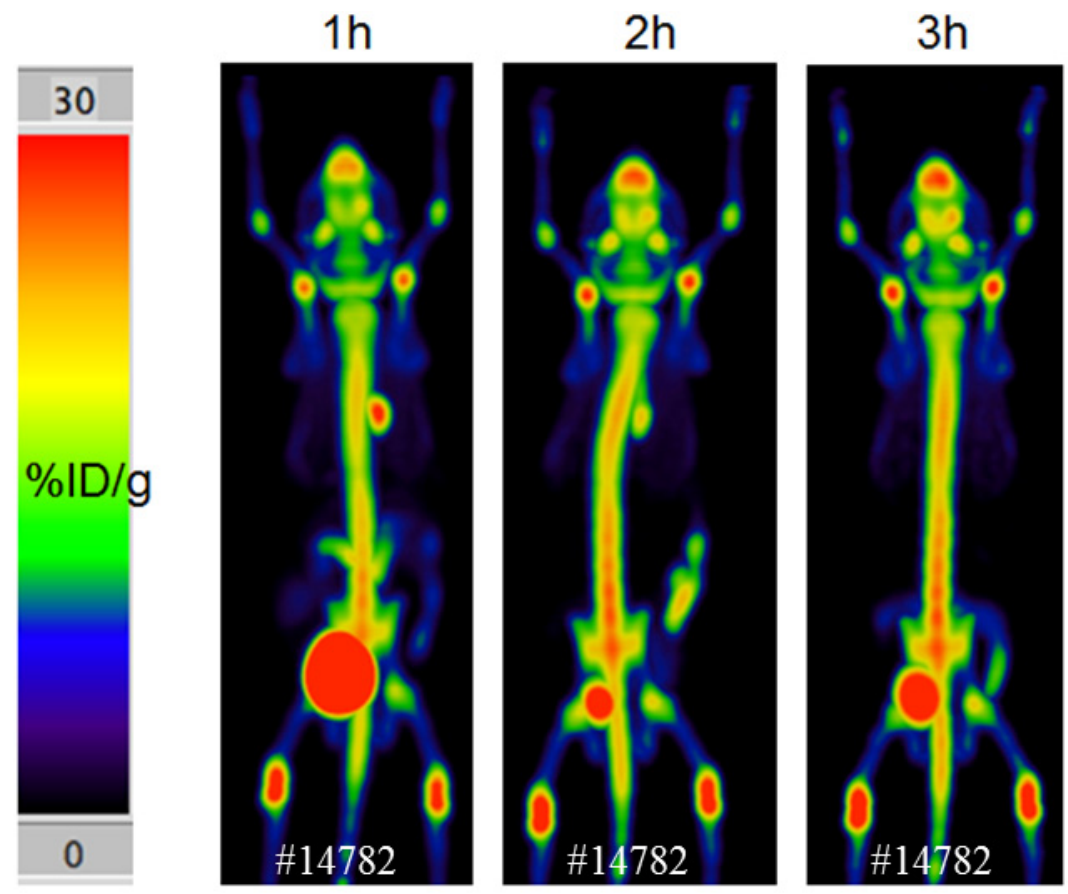

Figure 23. Time-dependent study of $\left[{ }^{18} \mathrm{~F}\right]-4-N$-fluoroalkylgemcitabine uptake in $\mathrm{dCK}$ KO mice. 
The $\left[{ }^{18} \mathrm{~F}\right]-4-N$-fluoroalkylgemcitabine probe was also evaluated in mice bearing CEM leukemia tumors expressing normal levels of dCK and tumors with low levels of dCK. A comparison between the two murine models indicates dCK-independent accumulation of the radioligand signal in CEM leukemia tumors owing to similar uptake in the amounts of probe in dCK-WT (Figure 24), consistent with the findings from dCK- cell lines.
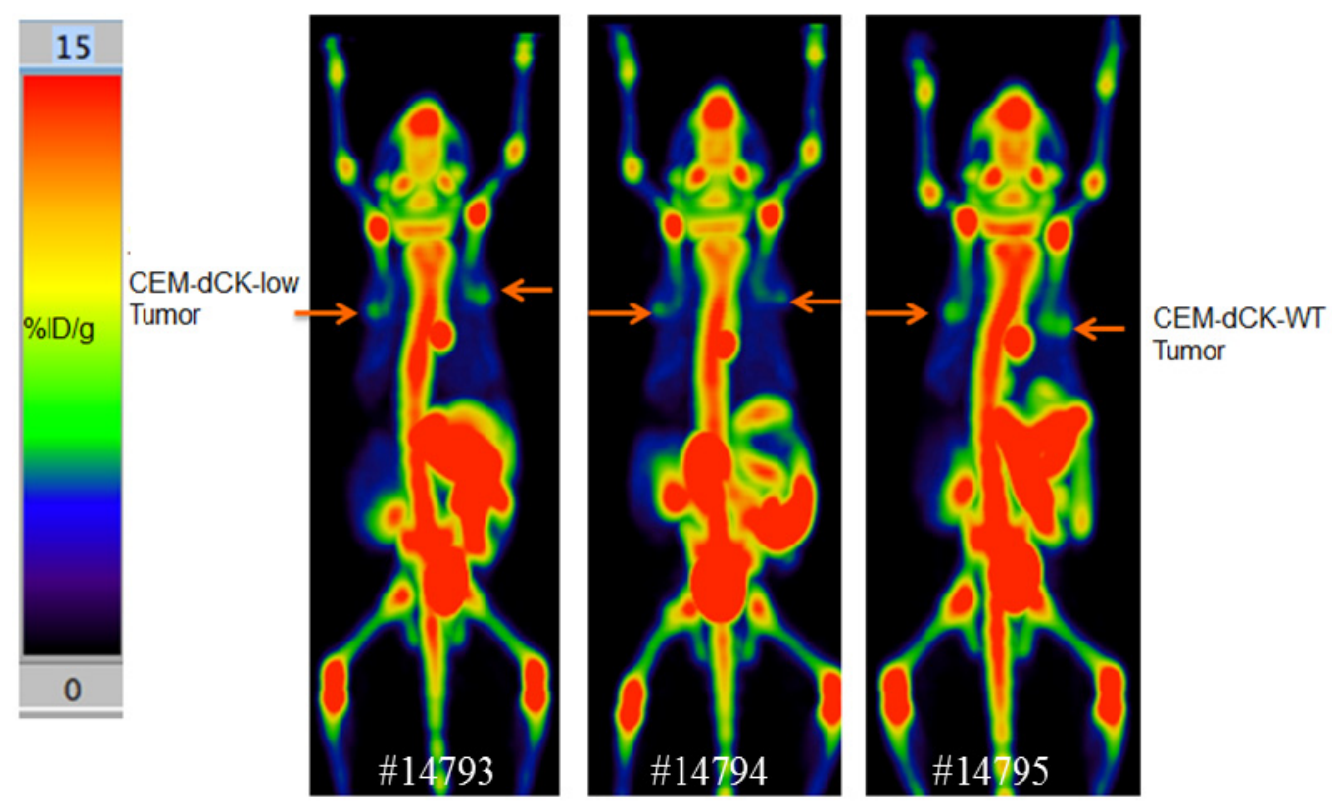

Figure 24. Uptake of $\left[{ }^{18} \mathrm{~F}\right]-4-N$-fluoroalkylgemcitabine in CEM-CCRF tumor bearing mice.

\subsection{2. $\left[{ }^{68} \mathrm{Ga}\right]-$ Labeling and evaluation of NOTA-4- $\mathrm{N}$-alkylgemcitabine radioligand.}

The $\left[{ }^{68} \mathrm{Ga}\right]{ }^{+3}(1.627 \mathrm{Ci}$ in $1 \mathrm{~mL}$ of $0.1 \mathrm{~N} \mathrm{HCl})$ was eluted from a ${ }^{68} \mathrm{Ge} /{ }^{68} \mathrm{Ga}$ generator with $\mathrm{H}_{2} \mathrm{O}$ for the labeling. Following previously elaborated conditions with regular $\mathrm{GaCl}_{3}$, the $\left[{ }^{68} \mathrm{Ga}\right]$-labeling was completed within $15 \mathrm{~min}$ and analyzed by TLC(Figure 25). The TLC plates eluted with $0.1 \mathrm{M}$ citric acid and analyzed by developing on a phosphoscreen, $\mathrm{R}_{\mathrm{f}}$ values of the free $\left.\left[{ }^{68} \mathrm{Ga}\right]\right]^{3+}$ and $\left[{ }^{68} \mathrm{Ga}\right]$-complexed 48 were "1.0" and " 0.0 " respectively, indicated a high labeling efficiency for the reaction as can be seen in 
Table 6. In lanes containing NOTA-4-N-alkylgemcitabine and $\left[{ }^{68} \mathrm{Ga}\right],{ }^{3+}$ the $\left[{ }^{68} \mathrm{Ga}\right]{ }^{3+}$ was observed to complex from $94 \%$ to $96 \%$.

Table 6. Labeling values for NOTA-4- $N$-alkylgemcitabine radioligand with ${ }^{68} \mathrm{Ga}$.

\begin{tabular}{|c|c|c|c|c|c|c|}
\hline & \multicolumn{2}{|c|}{ Trial 1} & \multicolumn{2}{|c|}{ Trial 2} & \multicolumn{2}{|c|}{ Trial 3} \\
\hline & Control & Cmpd & Control & Cmpd & Control & Cmpd \\
\hline $\begin{array}{l}\text { Counts in } \\
\text { upper } \\
\text { region }\end{array}$ & $\begin{array}{l}363069 \\
018\end{array}$ & $\begin{array}{l}252323 \\
30\end{array}$ & $\begin{array}{l}240306 \\
449\end{array}$ & $\begin{array}{l}100643 \\
31\end{array}$ & $\begin{array}{l}219716 \\
549\end{array}$ & $\begin{array}{l}645828 \\
7\end{array}$ \\
\hline $\begin{array}{l}\text { Counts in } \\
\text { lower } \\
\text { region }\end{array}$ & $\begin{array}{c}797088 \\
5\end{array}$ & $\begin{array}{l}374787 \\
348\end{array}$ & $\begin{array}{c}420891 \\
4\end{array}$ & $\begin{array}{l}256461 \\
215\end{array}$ & $\begin{array}{l}331927 \\
0\end{array}$ & $\begin{array}{l}166566 \\
169\end{array}$ \\
\hline $\begin{array}{l}\text { Percent } \\
\text { Efficiency }\end{array}$ & 98 & 94 & 98 & 96 & 99 & 96 \\
\hline
\end{tabular}

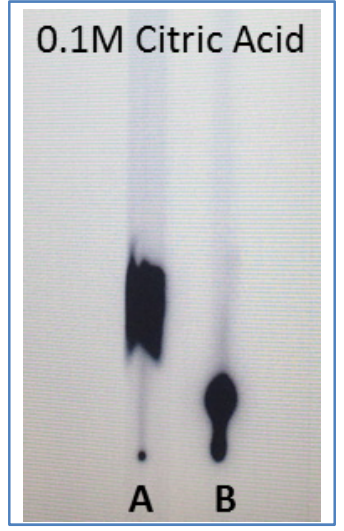

Figure 25. TLC for complexation of NOTA-4- $N$-alkylgemcitabine radioligand with ${ }^{68} \mathrm{Ga}$. Free $\left[{ }^{68} \mathrm{Ga}\right]{ }^{3+}$ (lane A) and $\left[{ }^{68} \mathrm{Ga}\right]$-complexed with NOTA-4- $N$-alkylgemcitabine (lane B).

The distribution coefficient was evaluated for the $\left[{ }^{68} \mathrm{Ga}\right]$-radioligand using octanol/ $\mathrm{H}_{2} \mathrm{O}$ and EtOAc/ $\mathrm{H}_{2} \mathrm{O}$ systems and found to be almost exclusively in favor of the aqueous layer, with less $<5 \%$ of the observed counts occurring in either organic phase (data not shown). The hydrophilic character of $\left[{ }^{68} \mathrm{Ga}\right]$-complexed 48 implies that the radioligand will not make a good candidate for further development as a theranostic agent. However, there is still potential for the development of other NOTA-4- $N$ alkylgemcitabine radioligands of similar structure to $\mathbf{4 8}$ with elongated alkyl chains (9-13 carbons) with more lipophilic character. 


\section{EXPERIMENTAL PROCEDURES}

\subsection{General Procedure}

The ${ }^{1} \mathrm{H}(400 \mathrm{MHz}),{ }^{13} \mathrm{C}(100 \mathrm{MHz})$, or ${ }^{19} \mathrm{~F}(376 \mathrm{MHz})$ NMR spectra were recorded at ambient temperature in solutions of $\mathrm{CDCl}_{3}$ or $\mathrm{MeOH}-d_{4}$ or DMSO- $d_{6}$, as noted. The reactions were followed by TLC with Merck Kieselgel $60-\mathrm{F}_{254}$ sheets and products were detected with a $254 \mathrm{~nm}$ light or with Hanessian's stain. Column chromatography was performed using Merck Kieselgel 60 (230-400 mesh). Reagent grade chemicals were used and solvents were dried by reflux distillation over $\mathrm{CaH}_{2}$ under nitrogen gas, unless otherwise specified, and reactions carried out under Ar atmosphere. The carboxylic acid and amine derivatives used for the coupling with gemcitabine were either commercially availaible or prepared as described. The purity of the synthesized compounds was determined to be $\geq 95 \%$ by elemental analysis $(C, H, N)$ and/or HPLC on Phenomenex Gemini RP-C18 with isocratic mobile phase $\left(50 \% \mathrm{CH}_{3} \mathrm{CN} / \mathrm{H}_{2} \mathrm{O}\right)$ and flow rate of 5 $\mathrm{mL} / \mathrm{min}$. VassarStats $($ software was used for the statistical analysis. The mean values from triplicate experiments are presented and the standard deviations were calculated to estimate the degree of data variation, as specified for each experiment in the figure or table legend. Two-way ANOVA analysis was applied to calculate the statistical significance of the data ( $\mathrm{P}$ values). Reprinted data with permission from Pulido, J.; Sobczak, A. J.; Balzarini, J.; Wnuk, S. F. Synthesis and Cytostatic Evaluation of 4-NAlkanoyl and 4-N-Alkyl Gemcitabine Analogues. J. Med. Chem. 2014, 57, 191-203. Copyright (C) 2014, American Chemical Society. 


\subsection{Synthesis}

\section{General synthetic procedure for preparation of the 4-N-acyl gemcitabine}

derivatives (3-8). Procedure A. $N$-Methylmorpholine (1.1 eq.), 1-hydroxybenzotriazole (1.1 eq.), the appropriate carboxylic acid (1.1 eq.) and 1-ethyl-3-(3dimethylaminopropyl)carbodiimide (1.3 eq.) were sequentially added to a stirred solution of gemcitabine hydrochloride (1, 1.0 eq.) in DMF/DMSO $(3: 1,2 \mathrm{~mL})$ at ambient temperature under Argon. The reaction mixture was then gradually heated to $65^{\circ} \mathrm{C}$ (oilbath) and kept stirring overnight. After the reaction was completed (TLC), the reaction mixture was cooled to $15^{\circ} \mathrm{C}$ and partitioned between a small amount of brine and EtOAc. The organic phase was separated and the aqueous layer extracted with fresh portions of EtOAc $(3 \times 30 \mathrm{~mL})$. The combined organic layers was then sequentially washed with $20 \% \mathrm{LiCl} / \mathrm{H}_{2} \mathrm{O}$, saturated $\mathrm{NaHCO}_{3} / \mathrm{H}_{2} \mathrm{O}$, brine, dried over $\mathrm{Na}_{2} \mathrm{SO}_{4}$, and evaporated under reduced pressure to give the crude products 3-8.

4- $N$-(Undecanoyl)-2'-deoxy-2',2'-difluorocytidine (3). Treatment of 1 (34 mg, 0.11 mmol) with commercially available undecanoic acid $(23.3 \mathrm{mg}, 0.120 \mathrm{mmol})$ by Procedure A gave $45.7 \mathrm{mg}$ of the crude product, which was then column chromatographed (5\% MeOH/EtOAc) to give $3(23.8 \mathrm{mg}, 50 \%)$ as a white solid: ${ }^{1} \mathrm{H}$ NMR $\left(\mathrm{CD}_{3} \mathrm{OD}\right) \delta 0.90\left(\mathrm{t}, J=6.9 \mathrm{~Hz}, 3 \mathrm{H}, \mathrm{CH}_{3}\right), 1.27-1.39\left(\mathrm{~m}, 14 \mathrm{H}, 7 \times \mathrm{CH}_{2}\right), 1.63-1.70$ (m, 2H, $\mathrm{CH}_{2}$ ), 2.45 (t, $\left.J=7.4 \mathrm{~Hz}, 2 \mathrm{H}, \mathrm{CH}_{2}\right), 3.79-3.83$ (m, 1H, H5'), 3.94-3.99 (m, 2H, H5', H4'), 4.31 (dt, $J=20.8,10.5 \mathrm{~Hz}, 1 \mathrm{H}, \mathrm{H} 3 '), 6.24-6.28\left(\mathrm{~m}, 1 \mathrm{H}, \mathrm{H} 1^{\prime}\right), 7.50(\mathrm{~d}, J=7.6$ $\mathrm{Hz}, 1 \mathrm{H}, \mathrm{H} 5), 8.34$ (d, $J=7.6 \mathrm{~Hz}, 1 \mathrm{H}, \mathrm{H} 6) ;{ }^{13} \mathrm{C} \mathrm{NMR}\left(\mathrm{CD}_{3} \mathrm{OD}\right)$ 14.41, 23.69, 25.93, 30.15, 30.40, 30.40, 30.56, 30.64, 33.03, 38.16, 60.29 (C5'), 70.21 ("t," J=23.1 Hz, C3'), $82.86(\mathrm{~d}, J=8.6 \mathrm{~Hz}, \mathrm{C} 4 '), 86.44\left(\mathrm{dd}, J=26.6,38.3 \mathrm{~Hz}, \mathrm{C} 1^{\prime}\right), 98.26$ (C5'), 123.90 (t, $J=$ 
$259.3 \mathrm{~Hz}, \mathrm{C} 2$ '), $145.94(\mathrm{C} 6), 157.65(\mathrm{C} 2), 164.80(\mathrm{C} 4), 175.97 ;{ }^{19} \mathrm{~F}$ NMR $\left(\mathrm{CD}_{3} \mathrm{OD}\right) \delta$ -

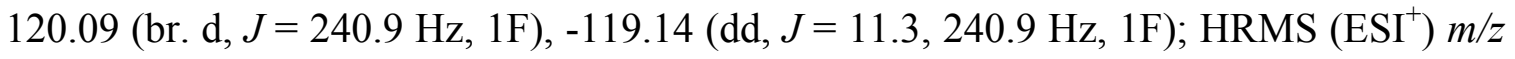
calcd for $\mathrm{C}_{20} \mathrm{H}_{31} \mathrm{~F}_{2} \mathrm{~N}_{3} \mathrm{NaO}_{5}[\mathrm{M}+\mathrm{Na}]^{+}$454.2124; found 454.2136.

4- $N$-(8-Nonenoyl)-2'-deoxy-2',2'-difluorocytidine (4). Treatment of 1 (34 mg, $0.110 \mathrm{mmol})$ with commercially available 8 -nonenoic acid ( $21 \mu \mathrm{L}, 19.5 \mathrm{mg}, 0.120 \mathrm{mmol})$ by Procedure A gave $29.0 \mathrm{mg}$ of the crude product, which was then column chromatographed ( $70 \rightarrow 100 \%$ EtOAc/hexane) to give 4 (20 $\mathrm{mg}, 45 \%)$ as a white solid: ${ }^{1} \mathrm{H}$ NMR $\left(\mathrm{CD}_{3} \mathrm{OD}\right) \delta$ 1.32-1.46 (br. s, $\left.6 \mathrm{H}, 3 \times \mathrm{CH}_{2}\right), 1.65-1.69$ (m, $\left.2 \mathrm{H}, \mathrm{CH}_{2}\right), 2.03-2.07$ (m, 2H, $\mathrm{CH}_{2}$ ), 2.45 (t, $\left.J=7.4 \mathrm{~Hz}, 2 \mathrm{H}, \mathrm{CH}_{2}\right), 3.81$ (dd, $\left.J=12.3,2.8 \mathrm{~Hz}, 1 \mathrm{H}, \mathrm{H} 5^{\prime}\right), 3.96-$ 3.99 (m, 2H, H5", H4'), 4.30 (td, $J=12.2,8.6 \mathrm{~Hz}, 1 \mathrm{H}, \mathrm{H} 3$ '), 4.90-5.01 (m, 2H, $\left.\mathrm{CH}_{2}\right), 5.81$ (ddt, $J=16.9,10.0,3.4 \mathrm{~Hz}, 1 \mathrm{H}, \mathrm{CH}), 6.24-6.28$ (m, 1H, H1'), 7.50 (d, $J=7.6 \mathrm{~Hz}, 1 \mathrm{H}$, H5), $8.34(\mathrm{~d}, J=7.6 \mathrm{~Hz}, 1 \mathrm{H}, \mathrm{H} 6) ;{ }^{13} \mathrm{C}$ NMR $\left(\mathrm{CD}_{3} \mathrm{OD}\right) \delta 25.90,29.87,29.90,30.00$, 34.79, 38.15, $60.31\left(\mathrm{C}^{\prime}\right), 70.23$ (dd, $\left.J=21.9,23.4 \mathrm{~Hz}, \mathrm{C} 3{ }^{\prime}\right), 82.86$ (C4'), 86.14 (d, $J=$ $20.1 \mathrm{~Hz}, \mathrm{C1}$ ), 98.28 (C5), 114.83, 123.94 (t, $J=259.2 \mathrm{~Hz}, \mathrm{C} 2$ '), 140.03, 145.97 (C6) , 157.37 (C2), 164.84 (C4), 175.97; ${ }^{19} \mathrm{~F} \mathrm{NMR}\left(\mathrm{CD}_{3} \mathrm{OD}\right) \delta-120.13$ (br. d, $\left.J=242.5 \mathrm{~Hz}, 1 \mathrm{~F}\right)$, $-119.21(\mathrm{dd}, J=11.4,240.0 \mathrm{~Hz}, 1 \mathrm{~F})$; HRMS $\left(\mathrm{ESI}^{+}\right) \mathrm{m} / z$ calcd for $\mathrm{C}_{18} \mathrm{H}_{25} \mathrm{~F}_{2} \mathrm{~N}_{3} \mathrm{NaO}_{5}$ $[\mathrm{M}+\mathrm{Na}]^{+}$424.1654; found 424.1656 .

4- $N$-(10-Undecenoyl)-2'-deoxy-2',2'-difluorocytidine (5). Treatment of 1 (40 mg, $0.134 \mathrm{mmol})$ with commercially available undecylenic acid ( $31 \mu \mathrm{L}, 28 \mathrm{mg}, 0.148 \mathrm{mmol})$ by Procedure A gave $114 \mathrm{mg}$ of the crude product, which was then column chromatographed ( $80 \rightarrow 100 \%$ EtOAc/hexane) to give 5 (38 $\mathrm{mg}, 66 \%)$ as a white solid: $\mathrm{UV}\left(\mathrm{CH}_{3} \mathrm{OH}\right) \lambda_{\max } 252 \mathrm{~nm}(\varepsilon 15150), 286 \mathrm{~nm}(\varepsilon 8950), \lambda_{\min } 228 \mathrm{~nm}(\varepsilon 5900), 275 \mathrm{~nm}(\varepsilon$ 8650); ${ }^{1} \mathrm{H}$ NMR (DMSO- $\left.d_{6}\right) \delta 1.23-1.29$ (br. s, $8 \mathrm{H}, 4 \times \mathrm{CH}_{2}$ ), $1.30-1.39\left(\mathrm{~m}, 2 \mathrm{H}, \mathrm{CH}_{2}\right.$ ), 
1.50-1.57 (m, 2H, $\left.\mathrm{CH}_{2}\right), 2.01$ (q, $\left.J=7.0 \mathrm{~Hz}, 2 \mathrm{H}, \mathrm{CH}_{2}\right), 2.40\left(\mathrm{t}, J=7.3 \mathrm{~Hz}, 2 \mathrm{H}, \mathrm{CH}_{2}\right)$, 3.66 ("br. d," $J=12.4 \mathrm{~Hz}, 1 \mathrm{H}, \mathrm{H} 5$ "), 3.81 (br. d, $J=12.4 \mathrm{~Hz}, 1 \mathrm{H}, \mathrm{H} 5$ '), 3.89 (dt, $J=8.5$, $2.7 \mathrm{~Hz}, 1 \mathrm{H}, \mathrm{H} 4$ '), 4.19 ("q," $J=10.6 \mathrm{~Hz}, 1 \mathrm{H}, \mathrm{H3}$ '), 4.93 ("d. quin," $J=10.1,1.0 \mathrm{~Hz}, 1 \mathrm{H}$, CH), 4.99 ("d. quin," $J=17.2,1.7 \mathrm{~Hz}, 1 \mathrm{H}, \mathrm{CH}$ ), 5.33 (br. t, $J=5.0 \mathrm{~Hz}, 1 \mathrm{H}, \mathrm{OH}$ ), 5.79 (tdd, $J=6.6,10.3,17.1 \mathrm{~Hz}, 1 \mathrm{H}, \mathrm{CH}$ ), 6.17 (t, $J=7.5 \mathrm{~Hz}, 1 \mathrm{H}, \mathrm{H1}$ '), 6.35 (br. s, $1 \mathrm{H}, \mathrm{OH}$ ), 7.29 (d, $J=7.6 \mathrm{~Hz}, 1 \mathrm{H}, \mathrm{H} 5), 8.24$ (d, $J=7.6 \mathrm{~Hz}, 1 \mathrm{H}, \mathrm{H} 6), 10.98$ (br. s, $1, \mathrm{NH}) ;{ }^{13} \mathrm{C}$ NMR $\left(\mathrm{CD}_{3} \mathrm{OD}\right) \delta 25.95,30.08,30.15\left(2 \times \mathrm{CH}_{2}\right), 30.37,30.39,34.88,38.18,60.32$ (C5'), 70.24 (dd, $\left.J=21.9,23.4 \mathrm{~Hz}, \mathrm{C}^{\prime}\right), 82.89(\mathrm{dd}, J=2.7,5.2 \mathrm{~Hz}, \mathrm{C} 4$ '), $86.48(\mathrm{dd}, J=25.8,38.2 \mathrm{~Hz}$, C1'), 98.28 (C5), 114.73, 123.93 (t, $J=259.2 \mathrm{~Hz}, \mathrm{C} 2$ '), 140.13, 145.97 (C6), 157.69 (C2), $164.83(\mathrm{C} 4), 176.00 ;{ }^{19} \mathrm{~F}$ NMR $\left(\mathrm{CD}_{3} \mathrm{OD}\right) \delta-120.09$ (br. d, $\left.J=239.6 \mathrm{~Hz}, 1 \mathrm{~F}\right),-119.16$ (dd, $J=10.9,239.9 \mathrm{~Hz}, 1 \mathrm{~F}) ; \mathrm{MS}\left(\mathrm{ESI}^{\dagger}\right) m / z 430\left(100,[\mathrm{M}+\mathrm{H}]^{+}\right)$. HRMS $\left(\mathrm{ESI}^{+}\right) m / z$ calcd for $\mathrm{C}_{20} \mathrm{H}_{29} \mathrm{~F}_{2} \mathrm{~N}_{3} \mathrm{NaO}_{5} \quad[\mathrm{M}+\mathrm{Na}]^{+}$452.1967; found 452.1982. Elemental Anal. calcd for $\mathrm{C}_{20} \mathrm{H}_{29} \mathrm{~F}_{2} \mathrm{~N}_{3} \mathrm{O}_{5} \bullet 0.5 \mathrm{H}_{2} \mathrm{O}$ (438.47): C, 54.79; H, 6.90; N, 9.58. Found: $\mathrm{C}, 54.48 ; \mathrm{H}, 6.53 ; \mathrm{N}$, 9.21 .

4- $N$-(12-Tridecenoyl)-2'-deoxy-2',2'-difluorocytidine (6). Treatment of 1 (30 mg, $0.1 \mathrm{mmol})$ with commercially available 12 -tridecenoic acid $(23 \mathrm{mg}, 0.11 \mathrm{mmol})$ by Procedure A gave $43.1 \mathrm{mg}$ of the crude product, which was then column chromatographed ( $70 \rightarrow 80 \%$ EtOAc/hexane) to give 6 (20.1 mg, 44\%) as a white solid: ${ }^{1} \mathrm{H}$ NMR $\left(\mathrm{CD}_{3} \mathrm{OD}\right) \delta 1.27-1.38\left(\mathrm{~m}, 14 \mathrm{H}, 7 \times \mathrm{CH}_{2}\right.$ ), 1.66 (quin, $J=6.9 \mathrm{~Hz}, 2 \mathrm{H}, \mathrm{CH}_{2}$ ), 2.04 (dd, $\left.J=14.3,6.7 \mathrm{~Hz}, 2 \mathrm{H}, \mathrm{CH}_{2}\right), 2.45\left(\mathrm{t}, J=7.4 \mathrm{~Hz}, 2 \mathrm{H}, \mathrm{CH}_{2}\right), 3.81(\mathrm{dd}, J=12.4,2.8 \mathrm{~Hz}$, 1H, H5'), 4.07-3.88 (m, 2H, H5", H4'), 4.31 (dt, $J=20.8,10.4$ Hz, 1H, H3'), 4.89-5.00 (m, 2H, $\mathrm{CH}_{2}$ ), 5.80 (ddt, $J=17.0,10.2,6.7 \mathrm{~Hz}, 1 \mathrm{H}, \mathrm{CH}$ ), 6.26 ("t," $J=7.2 \mathrm{~Hz}, 1 \mathrm{H}, \mathrm{H1}$ '), $7.50(\mathrm{~d}, J=7.6 \mathrm{~Hz}, 1 \mathrm{H}, \mathrm{H} 5), 8.34(\mathrm{~d}, J=7.6 \mathrm{~Hz}, 1 \mathrm{H}, \mathrm{H} 6) ;{ }^{13} \mathrm{C} \mathrm{NMR}\left(\mathrm{CD}_{3} \mathrm{OD}\right) \delta 25.94$, 
$30.11,30.15,30.20,30.39,30.53\left(2 \times \mathrm{CH}_{2}\right), 30.62,34.87,38.16,60.30,70.24$ ("t," $J=$ $23.1 \mathrm{~Hz}, \mathrm{C} 3$ '), 82.83 (C4'), 86.46 ("t," $J=32.2 \mathrm{~Hz}, \mathrm{C} 1$ '), 98.26 (C5), 114.67, 123.1 (t, $J=$ $260.1 \mathrm{~Hz}, \mathrm{C} 2$ ) $), 140.14,145.95$ (C6), 157.68 (C2), 164.82 (C4), 176.0; ${ }^{19} \mathrm{~F}$ NMR $\left(\mathrm{CD}_{3} \mathrm{OD}\right) \delta-120.13$ (br. d, $\left.J=239.4 \mathrm{~Hz}, 1 \mathrm{~F}\right),-119.21$ (dd, $\left.J=9.3,239.3 \mathrm{~Hz}, 1 \mathrm{~F}\right)$; HRMS $\left(\mathrm{ESI}^{+}\right) \mathrm{m} / z$ calcd for $\mathrm{C}_{22} \mathrm{H}_{33} \mathrm{~F}_{2} \mathrm{~N}_{3} \mathrm{NaO}_{5}[\mathrm{M}+\mathrm{Na}]^{+} 480.2280$; found 480.2289 .

4- $N$-(2-propylpentanoyl)-2'-deoxy-2',2'-difluorocytidine (7). ${ }^{149}$ Treatment of $\mathbf{1}$ (34 $\mathrm{mg}, 0.11 \mathrm{mmol})$ with commercially available 2-propylpentanoic acid $(20 \mu \mathrm{L}, 18 \mathrm{mg}$, $0.120 \mathrm{mmol}$ ) by Procedure A gave $25.0 \mathrm{mg}$ of crude product, which was then column chromatographed (5\% MeOH/EtOAc) to give 7 as a white solid $(17.7 \mathrm{mg}, 41 \%):{ }^{1} \mathrm{H}$ $\operatorname{NMR}\left(\mathrm{CD}_{3} \mathrm{OD}\right) \delta 0.92\left(\mathrm{t}, J=7.1 \mathrm{~Hz}, 6 \mathrm{H}, 2 \times \mathrm{CH}_{3}\right), 1.29-1.38\left(\mathrm{~m}, 4 \mathrm{H}, 2 \times \mathrm{CH}_{2}\right), 1.41-$ $1.50\left(\mathrm{~m}, 2 \mathrm{H}, \mathrm{CH}_{2}\right), 1.60-1.69\left(\mathrm{~m}, 2 \mathrm{H}, \mathrm{CH}_{2}\right), 2.50-2.58(\mathrm{~m}, 1 \mathrm{H}, \mathrm{CH}), 3.79-3.83(\mathrm{~m}, 1 \mathrm{H}$, H5'), 3.95-3.99 (m, 2H, H5", H4'), 4.31 (td, $J=12.2,8.5 \mathrm{~Hz}, 1 \mathrm{H}, \mathrm{H} 3$ '), 6.25-6.28 (m, 1H, $\left.\mathrm{H} 11^{\prime}\right), 7.53(\mathrm{~d}, J=7.6 \mathrm{~Hz}, 1 \mathrm{H}, \mathrm{H} 5), 8.36(\mathrm{~d}, J=7.6 \mathrm{~Hz}, 1 \mathrm{H}, \mathrm{H} 6) ;{ }^{13} \mathrm{C} \mathrm{NMR}\left(\mathrm{CD}_{3} \mathrm{OD}\right)$ 14.40, 21.62, 36.05, 48.36, 60.29 (C5'), 70.22 ("t," $J=23.1, \mathrm{C} 3$ '), 82.83 (C4'), 86.49 ("dd," $J=27.3,37.8 \mathrm{~Hz}, \mathrm{C1}$ '), 98.32 (C5'), 123.91 (t, $J=259.6 \mathrm{~Hz}, \mathrm{C} 2$ '), 146.09 (C6), 157.67 (C2), 164.76 (C4), 179.37; ${ }^{19} \mathrm{~F}$ NMR $\left(\mathrm{CD}_{3} \mathrm{OD}\right) \delta-120.95$ ("br. d," $J=240.0 \mathrm{~Hz}$, 1F), $-120.04(\mathrm{dd}, J=9.4,240.0 \mathrm{~Hz}, 1 \mathrm{~F})$.

4- $N$-(Diallylacetoyl)-2'-deoxy-2',2'-difluorocytidine (8). Treatment of 1 (40 mg, $0.134 \mathrm{mmol})$ with diallylacetic acid (A2, $21 \mathrm{mg}, 0.150 \mathrm{mmol})$ by Procedure A gave 45 mg of the crude product, which was then column chromatographed $(80 \rightarrow 90 \%$ EtOAc/hexane) to give 8 as a colorless oil (26.6 mg, 52\%): ${ }^{1} \mathrm{H}$ NMR (DMSO- $\left.d_{6}\right) \delta 2.16$ $2.34\left(\mathrm{~m}, 4 \mathrm{H}, 2 \times \mathrm{CH}_{2}\right), 2.78-2.85(\mathrm{~m}, 1 \mathrm{H}, \mathrm{CH}), 3.66(\mathrm{~d}, J=12.5 \mathrm{~Hz}, 1 \mathrm{H}, \mathrm{H} 5$ '), 3.81 (d, $J$ $=12.5 \mathrm{~Hz}, 1 \mathrm{H}, \mathrm{H} 5 "), 3.89$ (td, $J=2.8,8.4 \mathrm{~Hz}, 1 \mathrm{H}, \mathrm{H} 4$ '), 4.15-4.25 (m, 1H, H3'), 4.99- 
5.07 (m, 4H, $2 \mathrm{CH}_{2}$ ), 5.33 (br. s, 1H, OH), 5.69-5.79 (m, 2H, 2 x CH), 6.17 (t, $J=7.5 \mathrm{~Hz}$, 1H, H1'), 6.37 (br. s, 1H, OH), 7.29 (d, $J=7.6 \mathrm{~Hz}, 1 \mathrm{H}, \mathrm{H} 5), 8.25$ (d, $J=7.6 \mathrm{~Hz}, 1 \mathrm{H}, \mathrm{H} 6$ ), 11.07 (br. s, $1 \mathrm{H}, \mathrm{NH}) ;{ }^{1} \mathrm{H}$ NMR $\left(\mathrm{CD}_{3} \mathrm{OD}\right) \delta$ 2.25-2.45 (m, 4H, $\left.2 \times \mathrm{CH}_{2}\right)$, 2.69-2.76 (m, 1H, CH), 3.83 (dd, $\left.J=2.8,12.6 \mathrm{~Hz}, 1 \mathrm{H}, \mathrm{H} 5^{\prime}\right), 3.96-4.02$ (m, 2H, H5", H4'), 4.32 (dt, $J=$ 8.6, 12.0 Hz, 1H, H3'), 5.02-5.12 (m, 4H, 2 x CH 2 ), 5.76-5.86 (m, 2H, 2 x CH), 6.28 ("t," $J=7.2 \mathrm{~Hz}, 1 \mathrm{H}, \mathrm{H1}$ ) $), 7.50$ (d, $J=7.6 \mathrm{~Hz}, 1 \mathrm{H}, \mathrm{H} 5), 8.36$ (d, $J=7.6 \mathrm{~Hz}, 1 \mathrm{H}, \mathrm{H} 6) ;{ }^{13} \mathrm{C}$ NMR $\left(\mathrm{CD}_{3} \mathrm{OD}\right) \delta 37.25,37.27,48.28,60.31\left(\mathrm{C}^{\prime}\right), 70.19$ (dd, $\left.J=21.8,24.2 \mathrm{~Hz}, \mathrm{C}^{\prime}\right)$, 82.89 ("dd," $J=3.3,5.2 \mathrm{~Hz}, \mathrm{C} 4$ '), 86.50 (dd, $J=26.7,37.4 \mathrm{~Hz}, \mathrm{C1}$ ), 98.33 (C5), 117.63, 117.67, 123.93 (t, $J=259.4 \mathrm{~Hz}, \mathrm{C} 2$ '), 136.31, 136.33, 146.07 (C6), 157.66 (C2), 164.71 (C4), 177.61; ${ }^{19}$ F NMR (DMSO- $\left.d_{6}\right) \delta-116.93$ (br. s); ${ }^{19} \mathrm{~F}$ NMR $\left(\mathrm{CD}_{3} \mathrm{OD}\right) \delta-120.11$ ("br. d," $J=240.0 \mathrm{~Hz}, 1 \mathrm{~F}),-119.19(\mathrm{dd}, J=11.4,240.0 \mathrm{~Hz}, 1 \mathrm{~F}) ; \mathrm{MS}\left(\mathrm{ESI}^{+}\right) \mathrm{m} / z 386(100$, $\left.[\mathrm{M}+\mathrm{H}]^{+}\right)$. HRMS $\left(\mathrm{ESI}^{+}\right) \mathrm{m} / z$ calculated for $\mathrm{C}_{17} \mathrm{H}_{21} \mathrm{~F}_{2} \mathrm{~N}_{3} \mathrm{NaO}_{5}[\mathrm{M}+\mathrm{Na}]^{+}$408.1341; found 408.1339 .

4- $N$-(10-Fluoroundecanoyl)-2'-deoxy-2',2'-difluorocytidine (9). Method A. Chilled hydrogen fluoride/pyridine $(70 \%, 1.0 \mathrm{~mL})$ was added to $5(20 \mathrm{mg}, 0.044 \mathrm{mmol})$ in an HDPE vessel at $0{ }^{\circ} \mathrm{C}$ and stirred. After $2 \mathrm{~h}$, the reaction mixture was treated with saturated $\mathrm{NaHCO}_{3} / \mathrm{H}_{2} \mathrm{O}(10 \mathrm{~mL})$ and extracted with EtOAc $(3 \times 10 \mathrm{~mL})$. The combined organic layer was washed with brine, dried over $\mathrm{Na}_{2} \mathrm{SO}_{4}$, evaporated under reduced pressure and the resulting residue $(24.6 \mathrm{mg})$ was then column chromatographed $(70 \%$ EtOAc/hexane) to give $\mathbf{9}(19 \mathrm{mg}, 91 \%$; isomeric mixture of $\mathbf{9 : 1 0 : 1 1}$ in 75:20:5 ratio) as a white solid: UV ( $\left.\mathrm{CH}_{3} \mathrm{OH}\right) \lambda_{\max } 250 \mathrm{~nm}(\varepsilon 13250), 298 \mathrm{~nm}\left(\varepsilon\right.$ 5350), $\lambda_{\min } 226 \mathrm{~nm}(\varepsilon$ 4650), $279 \mathrm{~nm}\left(\varepsilon\right.$ 4700); ${ }^{1} \mathrm{H}$ NMR (DMSO-d $\left.{ }_{6}\right) \delta 1.22$ (br. d, $\left.J=6.1 \mathrm{~Hz}, 2 \mathrm{H}, \mathrm{CH}_{2}\right), 1.27$ (br. s, $8 \mathrm{H}, 4 \times \mathrm{CH}_{2}$ ), 1.29 (br. s, $2 \mathrm{H}, \mathrm{CH}_{2}$ ), $1.44-1.62$ (m, $5 \mathrm{H}, \mathrm{CH}_{2}, \mathrm{CH}_{3}$ ), 2.40 (t, $J=7.3$ 
$\mathrm{Hz}, 2 \mathrm{H}, \mathrm{CH}_{2}$ ), 3.66 (dt, $\left.J=12.5,4.3 \mathrm{~Hz}, 1 \mathrm{H}, \mathrm{H} 5 "\right), 3.81$ ("br. d," $J=12.0 \mathrm{~Hz}, 1 \mathrm{H}, \mathrm{H} 5$ '), 3.89 ("br. d," $J=8.5 \mathrm{~Hz}, 1 \mathrm{H}, \mathrm{H} 4$ '), 4.19 (sep, $J=6.4 \mathrm{~Hz}, 1 \mathrm{H}, \mathrm{H} 3$ '), 4.64 (dsex, $J=49.0$, $6.0 \mathrm{~Hz}, 1 \mathrm{H}, \mathrm{CH}), 5.31(\mathrm{t}, J=5.1 \mathrm{~Hz}, 1 \mathrm{H}, \mathrm{OH}), 6.17\left(\mathrm{t}, J=7.5 \mathrm{~Hz}, 1 \mathrm{H}, \mathrm{H} 1{ }^{\prime}\right), 6.33(\mathrm{~d}, J=$ $5.8 \mathrm{~Hz}, 1 \mathrm{H}, \mathrm{OH}), 7.29$ (d, $J=7.6 \mathrm{~Hz}, 1 \mathrm{H}, \mathrm{H} 5), 8.24$ (d, $J=7.6 \mathrm{~Hz}, 1 \mathrm{H}, \mathrm{H} 6), 10.98$ (s, 1H, $\mathrm{NH}) ;{ }^{13} \mathrm{C}$ NMR (DMSO- $\left.d_{6}\right) \delta 24.30,24.42,24.46,28.37,28.57,28.71,28.74,36.13$, 36.35, $58.78\left(\mathrm{C}^{\prime}\right), 68.37\left(\mathrm{t}, J=22.5 \mathrm{~Hz}, \mathrm{C} 3^{\prime}\right), 81.01\left(\mathrm{t}, J=3.9 \mathrm{~Hz}, \mathrm{C} 4^{\prime}\right), 84.50$ (d, $J=$ 82.2 Hz, C1'), 90.53 (d, $J=162.9$ Hz), 95.87 (C5), 124.18 (d, $J=260.1 \mathrm{~Hz}, \mathrm{C} 2 '), 144.68$ (C6), 154.17 (C2), $162.85(\mathrm{C} 4), 174.06 ;{ }^{19} \mathrm{~F}$ NMR (DMSO-d $) \delta$-170.27 (symmetric m, 0.75F), $\delta-116.91$ (br. s, 2F); MS (ESI) $m / z 450\left(100,[\mathrm{M}+\mathrm{H}]^{+}\right)$; HRMS (ESI $\left.{ }^{+}\right) m / z$ calcd for $\mathrm{C}_{20} \mathrm{H}_{30} \mathrm{~F}_{3} \mathrm{~N}_{3} \mathrm{NaO}_{5}[\mathrm{M}+\mathrm{Na}]^{+}$472.2030; found 472.2048. Elemental Anal. Calcd for $\mathrm{C}_{20} \mathrm{H}_{30} \mathrm{~F}_{3} \mathrm{~N}_{3} \mathrm{O}_{4} \cdot \mathrm{H}_{2} \mathrm{O} \bullet 0.33 \mathrm{CH}_{3} \mathrm{CN}$ (481.03): C, 51.59; H, 6.91; N, 9.70. Found: C, 51.36; H, 6.89; N, 9.97.

Minor isomers 10 [4- $N$-(9-Fluoroundecanoyl)] and 11 [4- $N-(8-$ Fluoroundecanoyl)] had the following distinguishable peaks: ${ }^{1} \mathrm{H}$ NMR (DMSO- $d_{6}$ ): $\delta 4.41$ (d quin, $J=49.6$, $5.8 \mathrm{~Hz}, 0.2, \mathrm{CHF}) ;{ }^{19} \mathrm{~F}$ NMR (DMSO- $\left.d_{6}\right) \delta-179.79$ (symmetric m, 0.15F), -178.83 (m, 0.1F), -116.91 (br. s, 2F).

Method B. Treatment of 1 (40 mg, $0.134 \mathrm{mmol}$ ) with 10-fluoroundecanoic acid (57, $31 \mathrm{mg}, 0.148 \mathrm{mmol}$, isomeric ratio 75:20:5) by Procedure A gave $77.0 \mathrm{mg}$ of the crude product, which was then column chromatographed $(90 \rightarrow 100 \%$ EtOAc/hexane) to give 9 as a white solid $(23.5 \mathrm{mg}, 39 \%$, isomeric ratio $75: 20: 5)$ with data as reported above.

4-N-[4-Fluoro-2-(2-fluoropropyl)-pentanoyl]-2'-deoxy-2',2'-difluorocytidine (12). Chilled hydrogen fluoride/pyridine $(70 \%, 1.0 \mathrm{~mL})$ was added to $8(21.0 \mathrm{mg}, 0.049 \mathrm{mmol})$ in an HDPE vessel at $0{ }^{\circ} \mathrm{C}$ and stirred. After $2.5 \mathrm{~h}$, the reaction mixture was treated with 
saturated $\mathrm{NaHCO}_{3} / \mathrm{H}_{2} \mathrm{O}(10 \mathrm{~mL})$ and extracted with EtOAc $(3 \times 10 \mathrm{~mL})$. The combined organic layer was washed with brine, dried over $\mathrm{Na}_{2} \mathrm{SO}_{4}$, evaporated under reduced pressure and the resulting residue $(15.0 \mathrm{mg})$ was then column chromatographed $(70 \%$ EtOAc/hexane) to give $\mathbf{1 2}$ (12 $\mathrm{mg}, 58 \%$; complex isomeric mixture) as a clear oil: MS (ESI) $m / z 426\left(100,[\mathrm{M}+\mathrm{H}]^{+}\right)$.

4- $N$-(11-Fluoroundecanoyl)-2'-deoxy-2',2'-difluorocytidine (13). Treatment of 1 (69.8 $\mathrm{mg}, 0.233 \mathrm{mmol})$ with 11 -fluoroundecanoic acid $(63,52 \mathrm{mg}, 0.256 \mathrm{mmol})$ by Procedure A gave $82.7 \mathrm{mg}$ of the crude product, which was then column chromatographed (70\% EtOAc/hexane) to give 13 (42.1 mg, 41\%) as a white solid: ${ }^{1} \mathrm{H}$ $\operatorname{NMR}\left(\mathrm{CD}_{3} \mathrm{OD}\right) \delta 1.35$ (br. s, $\left.12 \mathrm{H}, 6 \times \mathrm{CH}_{2}\right), 1.62-1.74\left(\mathrm{~m}, 4 \mathrm{H}, 2 \times \mathrm{CH}_{2}\right), 2.47(\mathrm{t}, J=7.4$ Hz, 2H, $\mathrm{CH}_{2}$ ), 3.83 (dd, $J=3.0,12.8 \mathrm{~Hz}, 1 \mathrm{H}, \mathrm{H} 5$ '), 3.96-4.02 (m, 2H, H5", H4'), 4.32 (dt, $\left.J=8.6,12.2 \mathrm{~Hz}, 1 \mathrm{H}, \mathrm{H} 3^{\prime}\right), 4.42\left(\mathrm{dt}, J=6.1,47.5 \mathrm{~Hz}, 2 \mathrm{H}, \mathrm{CH}_{2}\right), 6.28(\mathrm{t}, J=7.2 \mathrm{~Hz}, 1 \mathrm{H}$, $\mathrm{H} 1$ '), $7.51(\mathrm{~d}, J=7.6 \mathrm{~Hz}, 1 \mathrm{H}, \mathrm{H} 5), 8.35(\mathrm{~d}, J=7.6 \mathrm{~Hz}, 1 \mathrm{H}, \mathrm{H} 6) ;{ }^{13} \mathrm{C} \mathrm{NMR}\left(\mathrm{CD}_{3} \mathrm{OD}\right) \delta$ 25.95, 26.35, 30.16, 30.38, 30.48, 30.59, 31.50, 31.69, 38.17, 60.29(C5'), 70.20 ("t," $J=$ $23.0 \mathrm{~Hz}, \mathrm{C} 3$ '), 82.85 ("dd," $J=2.3,3.6 \mathrm{~Hz}, \mathrm{C} 4$ '), 84.89 (d, $J=163.8 \mathrm{~Hz}, \mathrm{CH}_{2} \mathrm{~F}$ ), 86.47 (dd, $J=29.6,34.7 \mathrm{~Hz}, \mathrm{C} 1), 98.29$ (C5), 123.94 (t, $J=259.2 \mathrm{~Hz}, \mathrm{C} 2$ '), 145.96 (C6), $157.69(\mathrm{C} 2), 164.83(\mathrm{C} 4), 176.01 ;{ }^{19} \mathrm{~F}$ NMR $\left(\mathrm{CD}_{3} \mathrm{OD}\right) \delta-219.87(\mathrm{tt}, J=24.7,47.5 \mathrm{~Hz}$, 1F), -120.09 (br. d, $J=239.0 \mathrm{~Hz}, 1 \mathrm{~F}$ ), -119.17 (br. dd, $J=10.2,239.0 \mathrm{~Hz}, 1 \mathrm{~F}$ ); MS (ESI) $m / z 450\left(100,[\mathrm{M}+\mathrm{H}]^{+}\right) ; \operatorname{HRMS}(+\mathrm{ESI}) \mathrm{m} / \mathrm{z}$ calcd for $\mathrm{C}_{20} \mathrm{H}_{30} \mathrm{~F}_{3} \mathrm{~N}_{3} \mathrm{NaO}_{5}[\mathrm{M}+\mathrm{Na}]^{+}$ 472.2023; found 472.2011.

\section{4- $N$-[11-(1H-benzotriazol-1-yloxy)-undecanoyl]-2'-deoxy-2',2'-difluorocytidine}

(14). Treatment of 1 (50 $\mathrm{mg}, 0.167 \mathrm{mmol})$ with commercially available 11bromoundecanoic acid ( $48.7 \mathrm{mg}, 0.184 \mathrm{mmol}$ ) by Procedure A gave $85.5 \mathrm{mg}$ of the crude 
product, which was then column chromatographed (5\% MeOH/EtOAc) to give 14 (50 mg, 53\%) as a white solid: ${ }^{1} \mathrm{H}$ NMR (DMSO- $\left.d_{6}\right) \delta 1.28$ (br. s, $\left.10 \mathrm{H}, \mathrm{CH}_{2}\right), 1.45-1.57(\mathrm{~m}$, 4H, $\mathrm{CH}_{2}$ ), $1.73-1.80\left(\mathrm{~m}, 2 \mathrm{H}, \mathrm{CH}_{2}\right), 2.40$ (t, $J=7.3 \mathrm{~Hz}, 2 \mathrm{H}, \mathrm{CH}_{2}$ ), 3.66 ("br. d," $J=13.6$ Hz, 1H, H5'), 3.80 ("br. d," $J=13.6 \mathrm{~Hz}, 1 \mathrm{H}, \mathrm{H} 5 "), 3.89$ (dt, $J=2.7,8.4 \mathrm{~Hz}, 1 \mathrm{H}, \mathrm{H} 4$ ') , 4.20 ("br. dt," $J=9.1,12.6 \mathrm{~Hz}, 1 \mathrm{H}, \mathrm{H3}$ '), 4.55 (t, $J=6.5 \mathrm{~Hz}, 2 \mathrm{H}, \mathrm{CH}_{2}$ ), 5.35 ("br. t," $J=$ 4.6 Hz, 1H, OH), 6.17 (t, $J=7.5 \mathrm{~Hz}, 1 \mathrm{H}, \mathrm{H1}$ ), 6.39 (br. s, 1H, OH), 7.28 (d, $J=7.6 \mathrm{~Hz}$, 1H, H5), 7.48 (t, $J=7.6 \mathrm{~Hz}, 1 \mathrm{H}, \mathrm{Ar}), 7.64$ (t, $J=7.6 \mathrm{~Hz}, 1 \mathrm{H}, \mathrm{Ar}), 7.82$ (d, $J=8.4 \mathrm{~Hz}$, 1H, Ar), 8.07 (d, $J=8.4 \mathrm{~Hz}, 1 \mathrm{H}, \mathrm{Ar}), 8.25$ (d, $J=7.6 \mathrm{~Hz}, 1 \mathrm{H}, \mathrm{H} 6), 10.99$ (br. s, 1H, NH); ${ }^{13} \mathrm{C}$ NMR $\left(\mathrm{CD}_{3} \mathrm{OD}\right) 25.90,26.64,29.12,30.06,30.24,30.28,30.35,30.40,38.14,58.32$, 60.30, 70.23 ("t," $J=23.1 \mathrm{~Hz}, \mathrm{C} 3$ '), 82.32, 82.89 (m, C4'), 98.25 (C5), 110.16, 120.50, $123.92,126.38,128.72,129.55,144.49,145.95,157.66,164.81,175.99 ;{ }^{19} \mathrm{~F}$ NMR $\left(\mathrm{CD}_{3} \mathrm{OD}\right) \delta-120.09$ (br. d, $\left.J=239.0 \mathrm{~Hz}, 1 \mathrm{~F}\right),-119.14(\mathrm{dd}, J=243.7,12.3 \mathrm{~Hz}, 1 \mathrm{~F})$ HRMS (+ESI) $m / z$ calcd for $\mathrm{C}_{26} \mathrm{H}_{34} \mathrm{~F}_{3} \mathrm{~N}_{6} \mathrm{NaO}_{6}[\mathrm{M}+\mathrm{Na}]^{+}$587.2406; found 587.2442.

4- $N$-(11-Chloroundecanoyl)-2'-deoxy-2',2'-difluorocytidine (15). Method A. TMSCl (79 $\mu \mathrm{L}, 68 \mathrm{mg}, 0.630 \mathrm{mmol})$ was added to a suspension of 1 (150 mg, 0.500 mmol) in $\mathrm{Pyr} / \mathrm{MeCN}(3: 1,2 \mathrm{~mL})$ at $0{ }^{\circ} \mathrm{C}$ under Ar and stirred for $2.5 \mathrm{~h}$, resulting in a clear solution. In a separate vessel, carbonyldiimidazole (CDI, $22.5 \mathrm{mg}, 0.138 \mathrm{mmol}$ ) was added to a solution of 11-bromoundecanoic acid (36.5 mg, $0.138 \mathrm{mmol})$ in $\mathrm{MeCN}(1 \mathrm{~mL})$ portion-wise and stirred at ambient temperature. After 30 minutes, the latter solution was combined with the previously prepared solution of transiently protected nucleoside and the new reaction mixture was stirred at $65{ }^{\circ} \mathrm{C}$ overnight. After $19 \mathrm{~h}$, EtOH $(2 \mathrm{~mL})$ was added and mixture followed by $\mathrm{H}_{2} \mathrm{O}(4 \mathrm{~mL})$ and the solution stirred at $65^{\circ} \mathrm{C}$ for $20 \mathrm{~min}$. The volatiles were then evaporated under reduced pressure and the residue was 
partitioned between EtOAc and $\mathrm{H}_{2} \mathrm{O}$, the $\mathrm{pH}$ was adjusted to 2.0 with phosphoric acid, and the aqueous layer was extracted with EtOAc. The combined organic layer was washed with saturated $\mathrm{NaHCO}_{3} / \mathrm{H}_{2} \mathrm{O}$, brine, dried over $\mathrm{Na}_{2} \mathrm{SO}_{4}$, evaporated under reduced pressure and the resulting residue $(47.2 \mathrm{mg})$ was column chromatographed $(70 \%$ EtOAc/hexane) to give $\mathbf{1 5}(11 \mathrm{mg}, 5 \%)$ as a white solid: ${ }^{1} \mathrm{H}$ NMR $\left(\mathrm{CD}_{3} \mathrm{OD}\right) \delta 1.34$ (br. s, $\left.10 \mathrm{H}, 2 \times \mathrm{CH}_{2}\right), 1.41-1.49\left(\mathrm{~m}, 2 \mathrm{H}, \mathrm{CH}_{2}\right), 1.66-1.71\left(\mathrm{~m}, 2 \mathrm{H}, \mathrm{CH}_{2}\right), 1.73-1.82\left(\mathrm{~m}, 2 \mathrm{H}, \mathrm{CH}_{2}\right)$, 2.47 (t, $J=7.5 \mathrm{~Hz}, 2 \mathrm{H}, \mathrm{CH}_{2}$ ), 3.56 (t, $J=6.7 \mathrm{~Hz}, 2 \mathrm{H}, \mathrm{CH}_{2}$ ), 3.83 ("dd," $J=12.7,3.1 \mathrm{~Hz}$, 1H, H5'), 3.96-4.03 (m, 2H, H5", H4'), 4.27-4.37 (m, 1H, H3'), 6.28 ("t," J= 7.2 Hz, 1H, $\left.\mathrm{H} 1{ }^{\prime}\right), 7.51(\mathrm{~d}, J=7.6 \mathrm{~Hz}, 1 \mathrm{H}, \mathrm{H} 5), 8.36(\mathrm{~d}, J=7.6 \mathrm{~Hz}, 1 \mathrm{H}, \mathrm{H} 6) ;{ }^{13} \mathrm{C} \mathrm{NMR}\left(\mathrm{CD}_{3} \mathrm{OD}\right) \delta$ 25.94, 27.93, 29.94, 30.13, 30.35, 30.43, 30.51, 33.83, 38.15, 45.74, 60.31 (C5'), 70.25 (C3'), 82.89 (C4'), 86.81 (C1'), 98.26 (C5), 123.93 (t, $J=258.0$ Hz, C2'), 145.97 (C6), $157.71(\mathrm{C} 2), 164.86(\mathrm{C} 4), 176.02(\mathrm{CO}) ;{ }^{19} \mathrm{~F}$ NMR $\left(\mathrm{CD}_{3} \mathrm{OD}\right) \delta-120.13$ (br. d, $J=240.2$ Hz, 1F), -119.2 (br. dd, $J=10.9,240.2 \mathrm{~Hz}, 1 \mathrm{~F})$; $\mathrm{MS}_{\left(\mathrm{ESI}^{+}\right) \mathrm{m} / z} 466\left(100,[\mathrm{M}+\mathrm{H}]^{+}\right.$for ${ }^{35} \mathrm{Cl}$ ), $468(100,[\mathrm{M}+\mathrm{H}]]^{+}$for ${ }^{37} \mathrm{Cl}$ ); HRMS $\left(\mathrm{ESI}^{+}\right) \mathrm{m} / z$ calcd for $\mathrm{C}_{20} \mathrm{H}_{30}{ }^{35} \mathrm{ClF}_{2} \mathrm{~N}_{3} \mathrm{NaO}_{5}$ $[\mathrm{M}+\mathrm{Na}]^{+}$488.1734; found 488.1742 .

Method B. $\mathrm{Et}_{3} \mathrm{~N}(28 \mu \mathrm{L}, 0.200 \mathrm{mmol})$ was added to a mixture of 11-bromoundecanoic acid $(26.6 \mathrm{mg}, 0.100 \mathrm{mmol})$ in THF $(1 \mathrm{~mL})$ and stirred at ambient temperature under Ar. The reaction mixture was then cooled to $-15{ }^{\circ} \mathrm{C}$ followed by the dropwise addition of a solution of $\mathrm{ClCO}_{2} \mathrm{Et}(19 \mu \mathrm{L}, 0.200 \mathrm{mmol})$ in THF $(0.5 \mathrm{~mL})$ with continued stirring. After 15 minutes, a solution of 1 (30 mg, $0.100 \mathrm{mmol})$ in DMF/DMSO (2.5 mL, 1.5:1) was added dropwise and the reaction mixture allowed to warm up to ambient and kept stirring overnight. After $24 \mathrm{~h}$, the reaction was treated with $\mathrm{NaHCO}_{3}$ and extracted with EtOAc (3x). The combined organic layer was washed with brine, dried over $\mathrm{Na}_{2} \mathrm{SO}_{4}$, evaporated 
under reduced pressure and the residue was column chromatographed $(70 \%$ EtOAc/hexane) to give $\mathbf{1 5}(7 \mathrm{mg}, 15 \%)$ with data as reported above.

\section{4- $\mathrm{N}-(11-B r o m o u n d e c a n o y l)-3 ', 5 '-d i-O$-(tert-butoxycarbonyl)-2'-deoxy-2',2'-}

difluorocytidine (17). A solution of $\mathbf{1 6}^{159}(35.5 \mathrm{mg}, 0.077 \mathrm{mmol})$ and $\mathrm{NaHCO}_{3}(400 \mathrm{mg}$, $4.76 \mathrm{mmol})$ in $\mathrm{CH}_{2} \mathrm{Cl}_{2}(0.5 \mathrm{~mL})$ was added to a stirred solution of 11-bromoundecanoyl chloride $(64,0.1 \mathrm{~mL}, 122 \mathrm{mg}, 0.43 \mathrm{mmol})$ in $\mathrm{CH}_{2} \mathrm{Cl}_{2}(1 \mathrm{~mL})$ at $0^{\circ} \mathrm{C}$ under Ar. After 15 minutes, the reaction mixture was allowed to warm up to ambient temperature and kept stirring for $3 \mathrm{~h}$. The reaction mixture was quenched by addition of saturated $\mathrm{NaHCO}_{3} / \mathrm{H}_{2} \mathrm{O}$, the mixture partitioned with water and the aqueous layer was extracted with $\mathrm{CH}_{2} \mathrm{Cl}_{2}(2 \times 10 \mathrm{~mL})$. The combined organic layer was washed with brine, dried over $\mathrm{Na}_{2} \mathrm{SO}_{4}$, evaporated under reduced pressure and the resulting residue (141.0 mg) was chromatographed (25\% EtOAc/hexane) to give $17(18 \mathrm{mg}, 33 \%)$ as a colorless oil: ${ }^{1} \mathrm{H}$ NMR $\left(\mathrm{CDCl}_{3}\right) \delta 1.30$ (br. s, 10H, 5 x CH $\left.\mathrm{CH}_{2}\right), 1.40-1.45\left(\mathrm{~m}, 2 \mathrm{H}, \mathrm{CH}_{2}\right), 1.53(\mathrm{~s}, 18 \mathrm{H}, 6 \mathrm{x}$ $\mathrm{CH}_{3}$ ), 1.68 ("quin," $J=7.3 \mathrm{~Hz}, 2 \mathrm{H}, \mathrm{CH}_{2}$ ), 1.86 ("quin," $J=7.3 \mathrm{~Hz}, 2 \mathrm{H}, \mathrm{CH}_{2}$ ), 2.48 (t, $J=$ $\left.7.5 \mathrm{~Hz}, 2 \mathrm{H}, \mathrm{CH}_{2}\right), 3.42$ (t, $\left.J=6.9 \mathrm{~Hz}, 2 \mathrm{H}, \mathrm{CH}_{2}\right), 4.37-4.50$ (m, 3H, H4', H5',5"), 5.14 ("dt," $J=4.5,11.2 \mathrm{~Hz}, 1 \mathrm{H}, \mathrm{H3}$ '), 6.46 (dd, $J=7.3,9.5 \mathrm{~Hz}, 1 \mathrm{H}, \mathrm{H} 1$ '), 7.51 (d, $J=7.6 \mathrm{~Hz}$ 1H, H5), 7.85 (d, $J=7.6 \mathrm{~Hz}, 1 \mathrm{H}, \mathrm{H} 6), 9.05$ (br. s, $1 \mathrm{H}, \mathrm{NH}) ;{ }^{13} \mathrm{C} \mathrm{NMR}\left(\mathrm{CDCl}_{3}\right) \delta 24.77$, $27.54,27.70,28.14,28.72,28.96,29.22,29.26,29.33,32.82,34.07,37.58,63.87$ (C5'), $72.64(\mathrm{dd}, J=17.2,34.0 \mathrm{~Hz}, \mathrm{C} 3 '), 77.79\left(\mathrm{C}^{\prime}\right), 83.37,84.21$ (m, C1'), 84.83, 97.02 (C5), 120.40 (dd, $J=260.7,267.3 \mathrm{~Hz}, \mathrm{C} 2 '), 145.27$ (C6), 151.42, 152.91, 153.94 (C2), 163.40 (C4), 174.17; ${ }^{19} \mathrm{~F} \mathrm{NMR}\left(\mathrm{CDCl}_{3}\right) \delta-120.00$ (br. d, $\left.J=246.9 \mathrm{~Hz}, 1 \mathrm{~F}\right),-115.57$ (dt, $J=11.4$, $246.9 \mathrm{~Hz}, 1 \mathrm{~F})$; $\mathrm{MS}\left(\mathrm{ESI}^{+}\right) \mathrm{m} / \mathrm{z} 710\left(100,[\mathrm{M}+\mathrm{H}]^{+}\right.$for $\left.{ }^{79} \mathrm{Br}\right), 712\left(100,[\mathrm{M}+\mathrm{H}]^{+}\right.$for $\left.{ }^{81} \mathrm{Br}\right)$. 
4- $N$-(11-Bromoundecanoyl)-2'-deoxy-2',2'-difluorocytidine (18). Compound 17 (32 $\mathrm{mg}, 0.045 \mathrm{mmol})$ was dissolved in TFA $(1.0 \mathrm{~mL})$ and the mixture was stirred at 20 ${ }^{\circ} \mathrm{C}$. After $4 \mathrm{~h}$, the reaction mixture was diluted with toluene, the volatiles were evaporated, and the residue co-evaporated with a fresh portion of toluene. The resulting residue $(32 \mathrm{mg})$ was column chromatographed $(80 \rightarrow 100 \%$ EtOAc/hexane) to give $\mathbf{1 8}$ (19.9 mg, 86\%) as a colorless solid: ${ }^{1} \mathrm{H}$ NMR $\left(\mathrm{CD}_{3} \mathrm{OD}\right): \delta 1.31-1.41\left(\mathrm{~m}, 10 \mathrm{H}, 5 \times \mathrm{CH}_{2}\right)$, 1.41-1.52 (m, 2H, $\left.\mathrm{CH}_{2}\right), 1.63-1.73\left(\mathrm{~m}, 2 \mathrm{H}, \mathrm{CH}_{2}\right), 1.81-1.89\left(\mathrm{~m}, 2 \mathrm{H}, \mathrm{CH}_{2}\right), 2.47(\mathrm{t}, J=7.4$ $\left.\mathrm{Hz}, 2 \mathrm{H}, \mathrm{CH}_{2}\right), 3.45$ (t, $\left.J=6.7 \mathrm{~Hz}, 2 \mathrm{H}, \mathrm{CH}_{2}\right), 3.75-3.89$ (m, 1H, H5"), 3.93-4.05 (m, 2H, H4', H5"), 4.32 (dt, $J=8.5,12.2 \mathrm{~Hz}, 1 \mathrm{H}, \mathrm{H} 3$ '), 6.28 ("t," $J=7.3 \mathrm{~Hz}, 1 \mathrm{H}, \mathrm{H} 1$ '), 7.51 (d, $J=$ 7.6 Hz, 1H, H5), 8.35 (d, $J=7.6 \mathrm{~Hz}, 1 \mathrm{H}, \mathrm{H} 6) ;{ }^{13} \mathrm{C} \mathrm{NMR}\left(\mathrm{CD}_{3} \mathrm{OD}\right) \delta 25.94,29.17,29.80$, $30.13,30.34,30.43,30.48,34.01,34.42,38.17,60.32$ (C5'), 70.25 (dd, $J=22.2,23.6 \mathrm{~Hz}$, C3'), 82.88 ('d', $J=8.6 \mathrm{~Hz}, \mathrm{C4}$ '), 86.48 (dd, $J=26.6,37.6 \mathrm{~Hz}, \mathrm{C} 1), 98.29$ (C5), 123.93 (t, $\left.J=259.9 \mathrm{~Hz}, \mathrm{C}^{\prime}\right), 145.98(\mathrm{C} 6), 157.69$ (C2), $164.84(\mathrm{C} 4), 176.03 ;{ }^{19} \mathrm{~F}$ NMR $\left(\mathrm{CD}_{3} \mathrm{OD}\right) \delta$ -120.10 (br. d, $J=240.0 \mathrm{~Hz}, 1 \mathrm{~F}),-119.17$ (ddd, $J=3.9,12.1,240.0 \mathrm{~Hz}, 1 \mathrm{~F}) ; \mathrm{MS}\left(\mathrm{ESI}^{+}\right)$ $m / z 510\left(100,[\mathrm{M}+\mathrm{H}]^{+}\right.$for $\left.{ }^{79} \mathrm{Br}\right), 512\left(100,[\mathrm{M}+\mathrm{H}]^{+}\right.$for $\left.{ }^{81} \mathrm{Br}\right)$; HRMS $\left(\mathrm{ESI}^{+}\right) \mathrm{m} / z$ calcd for $\mathrm{C}_{20} \mathrm{H}_{30}{ }^{79} \mathrm{BrF}_{2} \mathrm{~N}_{3} \mathrm{NaO}_{5}[\mathrm{M}+\mathrm{Na}]^{+}$532.1229; found 532.1239.

\section{4- $\mathrm{N}$-(5-Bromo-2-propylpentanoyl)-3',5'-di-O-(tert-butoxycarbonyl)-2'-deoxy-}

$\mathbf{2}^{\prime}, \mathbf{2}^{\prime}$-difluorocytidine (19). A solution of $\mathbf{1 6}^{159}$ (40 mg, $\left.0.086 \mathrm{mmol}\right)$ and $\mathrm{NaHCO}_{3}(447$

$\mathrm{mg}, 5.32 \mathrm{mmol})$ in $\mathrm{CH}_{2} \mathrm{Cl}_{2}(0.5 \mathrm{~mL})$ was added to a stirred solution of 5-bromo-2propylpentanoyl chloride $(\mathbf{5 5}, 90 \mathrm{mg}, 0.370 \mathrm{mmol})$ in $\mathrm{CH}_{2} \mathrm{Cl}_{2}(1 \mathrm{~mL})$ at $0^{\circ} \mathrm{C}$ under $\mathrm{Ar}$. After 15 minutes, the reaction mixture was allowed to warm up to ambient temperature and kept stirring for $6 \mathrm{~h}$. The reaction mixture was quenched by addition of saturated $\mathrm{NaHCO}_{3} / \mathrm{H}_{2} \mathrm{O}$, the mixture partitioned with water and the aqueous layer was extracted 
with $\mathrm{CH}_{2} \mathrm{Cl}_{2}(2 \times 10 \mathrm{~mL})$. The combined organic layer was washed with brine, dried over $\mathrm{Na}_{2} \mathrm{SO}_{4}$, evaporated under reduced pressure and the resulting residue $(104 \mathrm{mg})$ was column chromatographed (33\% EtOAc/hexane) to give 19 (25 mg, 43\%) as a colorless oil: ${ }^{1} \mathrm{H}$ NMR $\left(\mathrm{CDCl}_{3}\right) \delta 0.91\left(\mathrm{t}, J=7.2 \mathrm{~Hz}, 3 \mathrm{H}, \mathrm{CH}_{3}\right), 1.31-1.39\left(\mathrm{~m}, 2 \mathrm{H}, \mathrm{CH}_{2}\right), 1.53$ (s, $\left.18 \mathrm{H}, 6 \times \mathrm{CH}_{3}\right), 1.64-1.92\left(\mathrm{~m}, 6 \mathrm{H}, 3 \times \mathrm{CH}_{2}\right), 2.49$ (br. s, $\left.1 \mathrm{H}, \mathrm{CH}\right), 3.38-3.44\left(\mathrm{~m}, 2 \mathrm{H}, \mathrm{CH}_{2}\right)$, 4.38-4.50 (m, 3H, H4', H5', H5"), 5.14 (dt, $J=4.2,12.2 \mathrm{~Hz}, 1 \mathrm{H}, \mathrm{H} 3$ '), 6.46 (dd, $J=7.2$, $9.5 \mathrm{~Hz}, 1 \mathrm{H}, \mathrm{H1}$ '), 7.53 (d, $J=7.6 \mathrm{~Hz}, 1 \mathrm{H}, \mathrm{H} 5$ ), 7.86 (d, $J=7.6 \mathrm{~Hz}, 1 \mathrm{H}, \mathrm{H6}$ ), 9.14 (br. d, $J$ $=25.5 \mathrm{~Hz}, 1 \mathrm{H}, \mathrm{NH}) ;{ }^{13} \mathrm{C} \mathrm{NMR}\left(\mathrm{CDCl}_{3}\right) \delta 13.98,20.51,27.54,27.70,30.27,30.87,33.08$, 34.79, 47.80, 63.86 (C5'), 72.82 (dd, $\left.J=18.0,36.1 \mathrm{~Hz}, \mathrm{C} 3^{\prime}\right), 77.77$ (C4'), 83.37, 84.20 (C1'), 84.83, 97.04 (C5), 120.37 (t, $J=264.0 \mathrm{~Hz}, \mathrm{C} 2$ '), 145.09 (C6), 151.43, 152.93, 154.51 (C2), 162.73 (C4), 175.92; ${ }^{19} \mathrm{~F}$ NMR $\left(\mathrm{CDCl}_{3}\right) \delta-120.07$ ("br. d," $J=246.7 \mathrm{~Hz}$, 1F), $-115.59(\mathrm{dt}, J=11.4,246.7 \mathrm{~Hz}, 1 \mathrm{~F}) ; \mathrm{MS}\left(\mathrm{ESI}^{+}\right) \mathrm{m} / z 668\left(100,[\mathrm{M}+\mathrm{H}]^{+}\right.$for $\left.{ }^{79} \mathrm{Br}\right), 670$ $\left(100,[\mathrm{M}+\mathrm{H}]^{+}\right.$for $\left.{ }^{81} \mathrm{Br}\right)$.

\section{$N^{4}$-(11-Hydroxyundecanoyl)-3',5'-O-di(tert-butoxycarbonyl)-2'-deoxy-2',2'-}

difluorocytidine (20). Treatment of $\mathbf{1 6}^{159}$ (39 $\mathrm{mg}, 0.084 \mathrm{mmol}$ ) with commercially available 11-hydroxyundecanoic acid (29 mg, $0.144 \mathrm{mmol}$ ) by Procedure A gave $102 \mathrm{mg}$ of the crude product, which was then column chromatographed $(55 \rightarrow 65 \%$ EtOAc/hexane) to give $\mathbf{2 0}(20 \mathrm{mg}, 37 \%)$ as a colorless oil: ${ }^{1} \mathrm{H} \mathrm{NMR}\left(\mathrm{CDCl}_{3}\right) \delta 1.30$ (br. s, 12H, $6 \times \mathrm{CH}_{2}$ ), 1.53 (s, 18H, 6 x CH CH$_{3}, 1.58$ ("quin," $J=6.9 \mathrm{~Hz}, 2 \mathrm{H}, \mathrm{CH}_{2}$ ), 1.69 ("quin," $J=7.4 \mathrm{~Hz}, 2 \mathrm{H}, \mathrm{CH}_{2}$ ), 2.47 (t, $J=7.5 \mathrm{~Hz}, 2 \mathrm{H}, \mathrm{CH}_{2}$ ), 3.65 (t, $J=6.6 \mathrm{~Hz}, 2 \mathrm{H}$, $\mathrm{CH}_{2}$ ), 4.37-4.50 (m, 3H, H4', H5',5"), 5.14 ("dt," $J=4.8,11.1 \mathrm{~Hz}, 1 \mathrm{H}, \mathrm{H} 3$ '), 6.46 (dd, $J=$ 7.2, $9.5 \mathrm{~Hz}, 1 \mathrm{H}, \mathrm{H1}$ '), 7.51 (d, $J=7.6 \mathrm{~Hz}, 1 \mathrm{H}, \mathrm{H} 5), 7.85$ (d, $J=7.6 \mathrm{~Hz}, 1 \mathrm{H}, \mathrm{H6}$ ), 9.08 (br. s, $1 \mathrm{H}, \mathrm{NH}) ;{ }^{13} \mathrm{C} \mathrm{NMR}\left(\mathrm{CDCl}_{3}\right) \delta 24.75,25.65,27.53,27.69,28.88,29.11,29.16,29.27$, 
29.38, 32.75, 37.78, 62.99, 63.88 (C5'), 72.67 (dd, $J=17.0,33.8 \mathrm{~Hz}, \mathrm{C} 3$ '), 77.73 (C4'), 83.33, 84.16 (dd, $\left.J=18.2,37.9 \mathrm{~Hz}, \mathrm{Cl}^{\prime}\right), 84.77,97.08$ (C5), 120.42 (t, $J=263.8 \mathrm{~Hz}, \mathrm{C} 2$ '), $144.78(\mathrm{C} 6), 151.44,152.93,154.67(\mathrm{C} 2), 162.93(\mathrm{C} 4), 173.46 ;{ }^{19} \mathrm{~F} \mathrm{NMR}\left(\mathrm{CDCl}_{3}\right) \delta$ 120.00 (br. d, $J=246.7 \mathrm{~Hz}, 1 \mathrm{~F}),-115.58(\mathrm{dt}, J=11.4,246.7 \mathrm{~Hz}, 1 \mathrm{~F}) ; \mathrm{MS}\left(\mathrm{ESI}^{+}\right) m / z 648$ $\left(100,[\mathrm{M}+\mathrm{H}]^{+}\right)$.

4-N-(11-Hydroxyundecanoyl)- 2'-deoxy-2',2'-difluorocytidine (21). Method $A$. Compound 20 (4.0 mg, $0.008 \mathrm{mmol})$ was dissolved in TFA $(1.0 \mathrm{~mL})$ and the mixture was stirred at $20{ }^{\circ} \mathrm{C}$. After $4 \mathrm{~h}$, the reaction mixture was diluted with toluene, the volatiles were evaporated, and the residue co-evaporated with a fresh portion of toluene. The resulting residue was column chromatographed $(80 \rightarrow 100 \%$ EtOAc/hexane) to give 21 (3.1 mg, 87\%) as a white solid: ${ }^{1} \mathrm{H}$ NMR $\left(\mathrm{CD}_{3} \mathrm{OD}\right) \delta 1.33$ (br. s, $\left.12 \mathrm{H}, 6 \times \mathrm{CH}_{2}\right), 1.49$ $1.54\left(\mathrm{~m}, 2 \mathrm{H}, \mathrm{CH}_{2}\right), 1.66$ (quin, $\left.J=7.2 \mathrm{~Hz}, 2 \mathrm{H}, \mathrm{CH}_{2}\right), 2.45\left(\mathrm{t}, J=7.4 \mathrm{~Hz}, 2 \mathrm{H}, \mathrm{CH}_{2}\right), 3.53$ (t, $\left.J=6.6 \mathrm{~Hz}, 2 \mathrm{H}, \mathrm{CH}_{2}\right), 3.81\left(\mathrm{dd}, J=3.1,12.8 \mathrm{~Hz}, 1 \mathrm{H}, \mathrm{H} 5^{\prime}\right), 3.94-3.99$ (m, 2H, H4', H5'), 4.26-4.34 (m, 1H, H3'), 6.26 ("t," J=7.3 Hz, 1H, H1'), 7.49 (d, J = 7.6 Hz, 1H, H5), $8.33(\mathrm{~d}, J=7.6 \mathrm{~Hz}, 1 \mathrm{H}, \mathrm{H} 6) ;{ }^{13} \mathrm{C} \mathrm{NMR}\left(\mathrm{CD}_{3} \mathrm{OD}\right) \delta 25.93,26.94,30.13,30.37,30.48$, 30.53, 30.64, 33.65, 38.17, 60.30 (C5'), 63.01, 70.23 ("t," J=23.0 Hz, C3'), 82.88 ("d," J $=9.0 \mathrm{~Hz}, \mathrm{C} 4$ '), 86.47 ("dd," $J=27.0,37.6 \mathrm{~Hz}, \mathrm{C} 1$ '), 98.25 (C5), 123.91 (t, $J=258.9 \mathrm{~Hz}$, C2'), 145.95 (C6), 157.67 (C2), 164.82 (C4), 176.00; ${ }^{19} \mathrm{~F}$ NMR (CD $\left.{ }_{3} \mathrm{OD}\right) \delta-120.16$ ("br. d," $J=239.0 \mathrm{~Hz}, 1 \mathrm{~F}),-119.21(\mathrm{dd}, J=10.5,242.6 \mathrm{~Hz}, 1 \mathrm{~F})$; HRMS $\left(\mathrm{ESI}^{+}\right) \mathrm{m} / z$ calcd for $\mathrm{C}_{20} \mathrm{H}_{31} \mathrm{~F}_{2} \mathrm{~N}_{3} \mathrm{NaO}_{6}[\mathrm{M}+\mathrm{Na}]^{+}$470.2073; found 470.2073.

Method B. Treatment of 1 (58 mg, $0.194 \mathrm{mmol})$ with commercially available 11hydroxyundecanoic acid (43 mg, $0.213 \mathrm{mmol})$ by Procedure A gave $75.5 \mathrm{mg}$ of the crude 
product, which was then column chromatographed $\left(7.5 \% \mathrm{MeOH} / \mathrm{CHCl}_{3}\right)$ to give 21 (35 $\mathrm{mg}, 40 \%$ ) with data as reported above.

\section{4- $\mathrm{N}$-(11-Trifluoromethanesulfonyloxyundecanoyl)-3',5'-O-di(tert-}

butoxycarbonyl)-2'-deoxy-2',2'-difluorocytidine (22). Finely powdered $\mathrm{NaHCO}_{3}(4.2$ $\mathrm{mg}, 0.050 \mathrm{mmol})$ and triflic anhydride $(10 \mu \mathrm{L}, 14.0 \mathrm{mg}, 0.050 \mathrm{mmol})$ were sequentially added to a stirred solution of $\mathbf{2 0}(16.0 \mathrm{mg}, 0.025 \mathrm{mmol})$ in $\mathrm{CH}_{2} \mathrm{Cl}_{2}$ at $-60{ }^{\circ} \mathrm{C}$. After $1 \mathrm{~h}$, the reaction mixture was diluted with $\mathrm{CH}_{2} \mathrm{Cl}_{2}$, washed with $\mathrm{NaHCO}_{3} / \mathrm{H}_{2} \mathrm{O}$, brine and the volatiles evaporated under reduced pressure to give crude $22(10.9 \mathrm{mg}, 56 \%)$ as a colorless oil with $80 \%$ purity: ${ }^{19} \mathrm{~F}$ NMR $\left(\mathrm{CDCl}_{3}\right) \delta-121.05$ (br. d, $\left.J=241.7 \mathrm{~Hz}, 1 \mathrm{~F}\right)$, $\left.115.92(\mathrm{~d}, J=246.7 \mathrm{~Hz}, 1 \mathrm{~F}),-78.8(\mathrm{~s}, 3 \mathrm{~F}) ; \mathrm{MS}_{\left(\mathrm{ESI}^{+}\right)}\right) \mathrm{m} / \mathrm{z} 802.3\left(100,[\mathrm{M}+\mathrm{Na}]^{+}\right)$

\section{4- $N$-(11-Fluoroundecanoyl)-3',5'-di-O-(tert-butoxycarbonyl)-2'-deoxy-2',2'-}

difluorocytidine (23). A chilled $\left(-78^{\circ} \mathrm{C}\right)$ solution of DAST $(6.2 \mu \mathrm{L}, 7.6 \mathrm{mg}, 0.048$ mmol,) in $\mathrm{CH}_{2} \mathrm{Cl}_{2}(500 \mu \mathrm{L})$ was added to a stirred solution of $\mathbf{2 0}(9.8 \mathrm{mg}, 0.016 \mathrm{mmol})$ in $\mathrm{CH}_{2} \mathrm{Cl}_{2}(1.5 \mathrm{~mL})$ at $-78^{\circ} \mathrm{C}$. After 30 minutes, the reaction mixture was allowed to warm up to ambient temperature and kept stirring. After $2 \mathrm{~h}$, the reaction mixture was then poured into a separatory funnel containing a chilled solution of $\mathrm{NaHCO}_{3} / \mathrm{H}_{2} \mathrm{O}(10 \mathrm{~mL}$, $\mathrm{pH}=8)$ and was then extracted with $\mathrm{CHCl}_{3}(3 \times 10 \mathrm{~mL})$. The combined organic layer was washed with brine, dried over $\mathrm{MgSO}_{4}$, evaporated under reduced pressure and the resulting residue (14 mg) was column chromatographed $\left(5 \% \mathrm{MeOH} / \mathrm{CHCl}_{3}\right)$ to give $\mathbf{2 3}$ (4.2 mg, 40\%) as a colorless oil: ${ }^{1} \mathrm{H}$ NMR $\left(\mathrm{CDCl}_{3}\right) \delta 1.28$ (br. s, $\left.12 \mathrm{H}, 6 \times \mathrm{CH}_{2}\right), 1.51$ (s, 9H, $t$-Bu), 1.52 (s, 9H, $t$-Bu), 1.60-1.78 (m, 4H, $\left.2 \times \mathrm{CH}_{2}\right), 2.45$ (t, $J=7.4 \mathrm{~Hz}, 2 \mathrm{H}, \mathrm{CH}_{2}$ ), 4.38-4.47 (m, 3H, H4', H5', H5"), 4.44 (dt, $J=6.2,47.3 \mathrm{~Hz}, 2 \mathrm{H}, \mathrm{CH}_{2}$ ), 5.12-5.15 (m, 1H, H3'), 6.43 (t, $J=7.3 \mathrm{~Hz}, 1 \mathrm{H}, \mathrm{H1}$ '), 7.51-7.54 (m, 1H, H5), 7.87 (d, $J=7.0 \mathrm{~Hz}, 1 \mathrm{H}, \mathrm{H} 6$ ); 
${ }^{19} \mathrm{~F} \mathrm{NMR}\left(\mathrm{CDCl}_{3}\right) \delta-217.97(\mathrm{dt}, J=25.0,47.4 \mathrm{~Hz}, 2 \mathrm{~F}),-120.27$ (br. d, $J=240.7 \mathrm{~Hz}$, 1F), $-115.77(\mathrm{dt}, J=10.9,247.4 \mathrm{~Hz}, 1 \mathrm{~F})$; HRMS $\left(\mathrm{ESI}^{+}\right) \mathrm{m} / z$ calcd for $\mathrm{C}_{30} \mathrm{H}_{46} \mathrm{~F}_{3} \mathrm{~N}_{3} \mathrm{NaO}_{9}$ $[\mathrm{M}+\mathrm{Na}]^{+}$672.3078; found 672.3096.

Treatment of 23 (4.0 mg, $0.008 \mathrm{mmol})$ with TFA as descibed for 21 gave 13 (2.9 mg, $82 \%)$ with data sa reported above.

\section{4- $\mathrm{N}$-(p-Toluenosulfonyl)-3',5'-di-O-(tert-butoxycarbonyl)-2'-deoxy-2',2'-}

difluorocytidine (24). $\mathrm{Et}_{3} \mathrm{~N}(1.45 \mathrm{~mL}, 10.5 \mathrm{mmol})$ and $\mathrm{TsCl}(997 \mathrm{mg}, 5.2 \mathrm{mmol})$ were added to a solution of $16^{159}$ (242 $\left.\mathrm{mg}, 0.52 \mathrm{mmol}\right)$ in dry 1,4-dioxane (4.0 mL) and stirred at ambient temperature under Ar. The tightly sealed reaction mixture was then gradually heated to $65^{\circ} \mathrm{C}$ and kept stirring. After $24 \mathrm{~h}$, the reaction mixture was diluted with EtOAc, partitioned with saturated $\mathrm{NaHCO}_{3} / \mathrm{H}_{2} \mathrm{O}$ solution, and the aqueous layer was then extracted with EtOAc $(2 x)$. The combined organic layer was washed with brine, dried over $\mathrm{Na}_{2} \mathrm{SO}_{4}$, evaporated under reduced pressure and the resulting residue (403 $\mathrm{mg}$ ) was then column chromatographed (35\% EtOAc/hexane) to give $24(146 \mathrm{mg}, 45 \%)$ as a colorless, solidifying oil: ${ }^{1} \mathrm{H}$ NMR $\delta 1.49\left(\mathrm{~s}, 9 \mathrm{H}, 3 \times \mathrm{CH}_{3}\right), 1.52\left(\mathrm{~s}, 9 \mathrm{H}, 3 \times \mathrm{CH}_{3}\right), 2.43(\mathrm{~s}$, $\left.3 \mathrm{H}, \mathrm{CH}_{3}\right), 4.46-4.32$ (m, 3H, H4', H5', 5"), 5.11 (dt, $J=4.0,12.8 \mathrm{~Hz}, 1 \mathrm{H}, \mathrm{H} 3$ '), 5.80 (br. s, 1H, H5), 6.24 (dd, $\left.J=6.6,10.6 \mathrm{~Hz}, 1 \mathrm{H}, \mathrm{H} 1^{\prime}\right), 7.31$ (d, $\left.J=8.1 \mathrm{~Hz}, 2 \mathrm{H}, \mathrm{Ar}\right), 7.48$ (dd, $J$ $=1.9,8.1, \mathrm{~Hz}, 1 \mathrm{H}, \mathrm{H} 6), 7.84(\mathrm{~d}, J=8.3 \mathrm{~Hz}, 2 \mathrm{H}, \mathrm{Ar}), 10.96$ (br. s, $1 \mathrm{H}, \mathrm{NH}) ;{ }^{13} \mathrm{C} \mathrm{NMR} \delta$ 21.54, 27.51, 27.65, $63.80\left(\mathrm{C}^{\prime}\right), 72.40(\mathrm{dd}, J=16.9,33.8 \mathrm{~Hz}, \mathrm{C} 3$ '), $78.02(\mathrm{dd}, J=2.2$ $4.7 \mathrm{~Hz}, \mathrm{C} 4$ '), 83.31 (dd, $J=20.6,38.7 \mathrm{~Hz}, \mathrm{C} 1 '), 83.41,84.99,98.41$ (C5), 120.38 (dd, $J=$ 260.2, 266.5 Hz, C2'), 126.71 (Ar), 129.58 (Ar), 138.26 (d, $J=3.4 \mathrm{~Hz}, \mathrm{Ar}), 139.88$ (d, $J$ $=2.2 \mathrm{~Hz}, \mathrm{C} 6), 143.74(\mathrm{Ar}), 147.16(\mathrm{C} 2), 151.35,152.82,154.82(\mathrm{C} 4) ;{ }^{19} \mathrm{~F} \mathrm{NMR} \delta$ 120.59 (br. d, $J=247.6 \mathrm{~Hz}, 1 \mathrm{~F}),-115.80$ (br. d, $J=247.6 \mathrm{~Hz}, 1 \mathrm{~F}$ ); MS (ESI $\left.{ }^{+}\right) m / z 618$ 
(100, $\left.[\mathrm{M}+\mathrm{H}]^{+}\right)$; HRMS $\left(\mathrm{ESI}^{+}\right) \mathrm{m} / z$ calcd for $\mathrm{C}_{26} \mathrm{H}_{33} \mathrm{~F}_{2} \mathrm{~N}_{3} \mathrm{NaO}_{10} \mathrm{~S}[\mathrm{M}+\mathrm{Na}]^{+}$640.1747; found 640.1754 .

4- $N$-(n-Butyl)-2'-deoxy-2',2'-difluorocytidine (25). In a tightly sealed vessel, a mixture of $24(27 \mathrm{mg}, 0.044 \mathrm{mmol})$ and n-butyl amine $(0.5 \mathrm{~mL})$ was stirred at $60{ }^{\circ} \mathrm{C}$. After $24 \mathrm{~h}$, the volatiles were evaporated and the resulting residue $(74 \mathrm{mg})$ was column chromatographed ( $5 \rightarrow 8 \% \mathrm{MeOH} / \mathrm{EtOAc})$ to give 25 as a colorless solid ( $7.7 \mathrm{mg}, 55 \%)$ : ${ }^{1} \mathrm{H}$ NMR $\left(\mathrm{CD}_{3} \mathrm{OD}\right) \delta 0.97\left(\mathrm{t}, J=7.3 \mathrm{~Hz}, 3 \mathrm{H}, \mathrm{CH}_{3}\right), 1.37-1.47\left(\mathrm{~m}, 2 \mathrm{H}, \mathrm{CH}_{2}\right), 1.55-1.63$ (m, 2H, $\left.\left.\mathrm{CH}_{2}\right), 3.40\left(\mathrm{t}, J=7.1 \mathrm{~Hz}, 2 \mathrm{H}, \mathrm{CH}_{2}\right), 3.80(\mathrm{dd}, J=3.3,12.6 \mathrm{~Hz}, 1 \mathrm{H}, \mathrm{H} 5)^{\prime}\right), 3.89$ (td, $\left.J=2.7,8.3 \mathrm{~Hz}, 1 \mathrm{H}, \mathrm{H} 4{ }^{\prime}\right), 3.95$ (dd, $\left.J=2.4,12.7 \mathrm{~Hz}, 1 \mathrm{H}, \mathrm{H} 5 "\right), 4.26$ (dt, $J=8.3,12.1$ Hz, 1H, H3'), 5.87 (d, $J=7.6 \mathrm{~Hz}, 1 \mathrm{H}, \mathrm{H5}$ ), 6.23 ("t," $J=8.0 \mathrm{~Hz}, 1 \mathrm{H}, \mathrm{H1}$ '), 7.74 (d, $J=$ $7.6 \mathrm{~Hz}, 1 \mathrm{H}, \mathrm{H} 6) ;{ }^{13} \mathrm{C} \mathrm{NMR}\left(\mathrm{CD}_{3} \mathrm{OD}\right) \delta 14.10,21.12,32.09,41.46,60.56$ (C5'), 70.67 (dd, $\left.J=22.4,24.2 \mathrm{~Hz}, \mathrm{C}^{\prime}\right), 82.26\left(\mathrm{dd}, J=4.0,4.9 \mathrm{~Hz}, \mathrm{C} 4{ }^{\prime}\right), 85.94(\mathrm{dd}, J=26.7,37.4 \mathrm{~Hz}$, C1), 97.31 (C5), 124.05 (t, $J=258.4 \mathrm{~Hz}, \mathrm{C} 2$ '), 140.77 (C6), 158.30 (C2), 165.38 (C4); ${ }^{19} \mathrm{~F}$ NMR $\left(\mathrm{CD}_{3} \mathrm{OD}\right) \delta-119.90$ ("br. d," $\left.J=240.1 \mathrm{~Hz}, 1 \mathrm{~F}\right),-118.84$ (ddd, $J=3.8,12.3$, $238.5 \mathrm{~Hz}, 1 \mathrm{~F}) ; \mathrm{MS}\left(\mathrm{ESI}^{+}\right) \mathrm{m} / \mathrm{z} 320\left(100,[\mathrm{M}+\mathrm{H}]^{+}\right)$.

4- $N$-(10-Undecenyl)-2'-deoxy-2',2'-difluorocytidine (26). In a tightly sealed vessel, a mixture of 24 (40 mg, $0.065 \mathrm{mmol})$ and 1-amino-10-undecene $(0.50 \mathrm{~mL}, 404 \mathrm{mg}, 2.4$ mmol) was stirred at $60^{\circ} \mathrm{C}$. After $30 \mathrm{~h}$, the volatiles were evaporated the resulting residue was column chromatographed ( $8 \% \mathrm{MeOH} / \mathrm{EtOAc})$ to give $26(9.5 \mathrm{mg}, 36 \%)$ as colorless viscous oil: $\mathrm{UV}\left(\mathrm{CH}_{3} \mathrm{OH}\right) \lambda_{\max } 268 \mathrm{~nm}(\varepsilon 11600), \lambda_{\min } 228 \mathrm{~nm}(\varepsilon 7800) ;{ }^{1} \mathrm{H}$ NMR $\left(\mathrm{CD}_{3} \mathrm{OD}\right) \delta 1.43-1.30\left(\mathrm{~m}, 12 \mathrm{H}, 6 \times \mathrm{CH}_{2}\right), 1.65-1.56\left(\mathrm{~m}, 2 \mathrm{H}, \mathrm{CH}_{2}\right), 2.03-2.09(\mathrm{~m}, 2 \mathrm{H}$, $\left.\mathrm{CH}_{2}\right), 3.39$ (t, $\left.J=7.1 \mathrm{~Hz}, 2 \mathrm{H}, \mathrm{CH}_{2}\right), 3.80(\mathrm{dd}, J=3.3,12.6 \mathrm{~Hz}, 1 \mathrm{H}, \mathrm{H} 5$ '), 3.89 (td, $J=2.8$, $\left.8.3 \mathrm{~Hz}, 1 \mathrm{H}, \mathrm{H} 4{ }^{\prime}\right), 3.95$ (d, $\left.J=12.6 \mathrm{~Hz}, 1 \mathrm{H}, \mathrm{H} 5 "\right), 4.26$ (dt, $\left.J=8.3,12.1 \mathrm{~Hz}, 1 \mathrm{H}, \mathrm{H} 3{ }^{\prime}\right)$, 
4.91-5.02 (m, 2H, $\left.\mathrm{CH}_{2}\right), 5.82$ (tdd, $\left.J=6.7,10.3,17.0 \mathrm{~Hz}, 1 \mathrm{H}, \mathrm{CH}\right), 5.87$ (d, $J=7.6 \mathrm{~Hz}$, 1H, H5), 6.23 (t, $J=8.0 \mathrm{~Hz}, 1 \mathrm{H}, \mathrm{H} 1$ '), $7.74(\mathrm{~d}, J=7.6 \mathrm{~Hz}, 1 \mathrm{H}, \mathrm{H} 6) ;{ }^{13} \mathrm{C} \mathrm{NMR}\left(\mathrm{CD}_{3} \mathrm{OD}\right) \delta$ 28.01, 29.98, 30.12, 30.19, 30.42, 30.51, 30.63, 34.88, 41.75, 60.56 (C5'), 70.67 (dd, $J=$ 22.4, $\left.23.8 \mathrm{~Hz}, \mathrm{C} 3^{\prime}\right), 82.26$ (dd, $J=3.6,5.0 \mathrm{~Hz}, \mathrm{C} 4$ '), 85.94 (dd, $J=26.0,38.0 \mathrm{~Hz}, \mathrm{C} 1$ ), 97.33 (C5), 114.68, 124.05 (t, $J=258.4 \mathrm{~Hz}, \mathrm{C2}$ '), 140.16, 140.77 (C6), 158.30 (C2), 165.37 (C4); ${ }^{19} \mathrm{~F}$ NMR $\left(\mathrm{CD}_{3} \mathrm{OD}\right) \delta-119.89$ (br. d, $\left.J=240.1 \mathrm{~Hz}, 1 \mathrm{~F}\right),-118.80$ (br. d, $J=$ $240.1 \mathrm{~Hz}, 1 \mathrm{~F}) ; \mathrm{MS}\left(\mathrm{ESI}^{+}\right) \mathrm{m} / \mathrm{z} 416\left(100,[\mathrm{M}+\mathrm{H}]^{+}\right)$; HRMS $\left(\mathrm{ESI}^{+}\right) \mathrm{m} / \mathrm{z}$ calcd for $\mathrm{C}_{20} \mathrm{H}_{31} \mathrm{~F}_{2} \mathrm{~N}_{3} \mathrm{NaO}_{4} \quad[\mathrm{M}+\mathrm{Na}]^{+}$438.2175; found 438.2178; Elemental Anal. Calcd for $\mathrm{C}_{20} \mathrm{H}_{31} \mathrm{~F}_{2} \mathrm{~N}_{3} \mathrm{O}_{4} \cdot 0.5 \mathrm{H}_{2} \mathrm{O} \cdot 0.5 \mathrm{CH}_{3} \mathrm{CN}$ (445.01): $\mathrm{C}, 56.68 ; \mathrm{H}, 7.59 ; \mathrm{N}, 11.02$. Found: $\mathrm{C}$, $56.93 ; \mathrm{H}, 7.77 ; \mathrm{N}, 10.76$.

4-N-(9-Fluoroundecanyl)-2'-deoxy-2',2'-difluorocytidine (28). Chilled hydrogen fluoride/pyridine $(70 \%, 1.0 \mathrm{~mL})$ was added to $26(10.3 \mathrm{mg}, 0.025 \mathrm{mmol})$ in an HDPE vessel at $0^{\circ} \mathrm{C}$ and stirred. After $4 \mathrm{~h}$, the reaction mixture was treated with saturated $\mathrm{NaHCO}_{3} / \mathrm{H}_{2} \mathrm{O}(1.0 \mathrm{~mL})$ and extracted with EtOAc $(3 \times 10 \mathrm{~mL})$. The combined organic layer was washed with brine, dried over $\mathrm{Na}_{2} \mathrm{SO}_{4}$ and concentrated under reduced pressure and the resulting residue $(10.6 \mathrm{mg})$ was column chromatographed $\left(4 \% \mathrm{MeOH} / \mathrm{CHCl}_{3}\right)$ to give 28 (8.4 mg, 78\%, isomeric mixture of $\mathbf{2 7 : 2 8 : 2 9}$ in 20:45:35 ratio) as a colorless oil: ${ }^{1} \mathrm{H}$ NMR $\left(\mathrm{CD}_{3} \mathrm{OD}\right) \delta$ 0.89-1.00 (m, 3H, $\left.\mathrm{CH}_{3}\right), 1.24-1.68\left(\mathrm{~m}, 18 \mathrm{H}, 9 \times \mathrm{CH}_{2}\right), 3.39(\mathrm{t}, J=$ $\left.7.2 \mathrm{~Hz}, 2 \mathrm{H}, \mathrm{CH}_{2}\right), 3.80$ (dd, $\left.J=3.3,12.6 \mathrm{~Hz}, 1 \mathrm{H}, \mathrm{H}^{\prime}\right), 3.89$ (td, $\left.J=2.8,8.3 \mathrm{~Hz}, 1 \mathrm{H}, \mathrm{H} 4^{\prime}\right)$, 3.95 (br. dd, $\left.J=2.1,12.6,1 \mathrm{H}, \mathrm{H} 5^{\prime \prime}\right), 4.26$ (dt, $\left.J=8.3,12.1 \mathrm{~Hz}, 1 \mathrm{H}, \mathrm{H} 3^{\prime}\right), 4.46$ (dm, $J=$ $49.8 \mathrm{~Hz}, 1 \mathrm{H}, \mathrm{CHF}), 5.87$ (d, $J=7.6 \mathrm{~Hz}, 1 \mathrm{H}, \mathrm{H} 5), 6.23$ ("t," J=8.0 Hz, 1H, H1'), 7.74 (d, $J=7.6 \mathrm{~Hz}, 1 \mathrm{H}, \mathrm{H} 6) ;{ }^{13} \mathrm{C} \mathrm{NMR}\left(\mathrm{CD}_{3} \mathrm{OD}\right) \delta 9.67,9.72,14.28,14.32,19.44,19.49,21.23$, $21.45,23.63,26.19,26.22,27.91,28.00,29.90,29.97,30.35,30.40,30.56,30.58,32.87$, 
35.76, 35.93, 35.97, 36.14, 36.19, $36.25(\mathrm{~d}, J=21.1 \mathrm{~Hz}), 36.31(\mathrm{~d}, J=21.0 \mathrm{~Hz}), 38.10$ (d, $J=20.6 \mathrm{~Hz}), 38.50$ (d, $J=20.9 \mathrm{~Hz}), 41.73,60.56(\mathrm{C} 5 '), 70.67$ (dd, $J=22.4,24.0 \mathrm{~Hz}$, C3'), $82.26(\mathrm{dd}, J=3.0,5.7 \mathrm{~Hz}, \mathrm{C} 4$ '), 85.93 (dd, $J=27.1,37.0 \mathrm{~Hz}, \mathrm{C} 1), 95.16$ (d, $J=$ $149.0 \mathrm{~Hz}$ ), 97.32 (C5), 124.05 (t, $J=258.4 \mathrm{~Hz}, \mathrm{C} 2$ )), 140.77 (C6), 158.29 (C2), 165.37 (C4); ${ }^{19} \mathrm{~F}$ NMR $\left(\mathrm{CD}_{3} \mathrm{OD}\right) \delta-181.90(\mathrm{~m}, 0.45 \mathrm{~F}), 119.90$ (br. d, $\left.J=238.8 \mathrm{~Hz}, 1 \mathrm{~F}\right),-118.83$ $(\mathrm{dd}, J=9.2,238.8 \mathrm{~Hz}, 1 \mathrm{~F}) ; \mathrm{MS}\left(\mathrm{ESI}^{+}\right) \mathrm{m} / z 436\left(100,[\mathrm{M}+\mathrm{H}]^{+}\right) . \mathrm{HRMS}\left(\mathrm{ESI}^{+}\right) \mathrm{m} / z$ calcd for $\mathrm{C}_{20} \mathrm{H}_{32} \mathrm{~F}_{3} \mathrm{~N}_{3} \mathrm{O}_{4}\left[\mathrm{M}+\mathrm{Na}^{+}\right]$458.2237; found 458.2248.

Minor isomers 27 [4-N-(10-fluoroundecanyl)] and 29 [4- $N$-(8-fluoroundecanyl)] had the following distinguishable peaks: ${ }^{1} \mathrm{H} \mathrm{NMR}\left(\mathrm{CD}_{3} \mathrm{OD}\right) \delta 4.36(\mathrm{dm}, J=49.8 \mathrm{~Hz}, 0.2 \mathrm{H}$, CHF), $4.61(\mathrm{dm}, J=49.8 \mathrm{~Hz}, 0.35 \mathrm{H}, \mathrm{CHF}) ;{ }^{13} \mathrm{C} \mathrm{NMR}\left(\mathrm{CD}_{3} \mathrm{OD}\right) \delta 91.77(\mathrm{~d}, J=$ 164.3 Hz, CHF), 94.95 (d, $J=142.2 \mathrm{~Hz}, \mathrm{CHF}) ;{ }^{19} \mathrm{~F}$ NMR (CD $\left.3 \mathrm{OD}\right) \delta-183.01$ (m, 0.2F), $173.68(\mathrm{~m}, 0.35 \mathrm{~F})$,

4- $N$-(11-Hydroxyundecanyl)-2'-deoxy-2',2'-difluorocytidine (31). 11-Amino-1undecanol $(\mathbf{6 6}, 88 \mathrm{mg}, 0.47 \mathrm{mmol})$ and $\mathrm{Et}_{3} \mathrm{~N}(0.5 \mathrm{~mL})$ were added to a solution of $\mathbf{2 4}$ (23.2 $\mathrm{mg}, 0.038 \mathrm{mmol})$ in 1,4-dioxane $(0.5 \mathrm{~mL})$ and stirred at ambient temperature under Ar. The reaction mixture was then gradually heated to $65^{\circ} \mathrm{C}$ (oil bath) and kept stirring overnight. After $40 \mathrm{~h}$, the volatiles were evaporated and the residue $(97 \mathrm{mg}$ ) was column chromatographed $(1 \rightarrow 3 \% \mathrm{MeOH} / \mathrm{EtOAc})$ to give mono-protected product $30[9.5 \mathrm{mg}$, 47\%: ${ }^{1} \mathrm{H}$ NMR $\left(\mathrm{CD}_{3} \mathrm{OD}\right) \delta 1.32$ (br. s, $12 \mathrm{H}, 6 \times \mathrm{CH}_{2}$ ), 1.49 (s, 9H, $t$-Bu), 1.49-1.61 (m, 4H, $2 \times \mathrm{CH}_{2}$ ), 3.37 (t, $\left.J=7.1 \mathrm{~Hz}, 2 \mathrm{H}, \mathrm{CH}_{2}\right), 3.49-3.62\left(\mathrm{~m}, 2 \mathrm{H}, \mathrm{CH}_{2}\right), 4.17$ (dt, $J=9.9$, $19.4 \mathrm{~Hz}, 1 \mathrm{H}, \mathrm{H} 4$ '), 4.02-4.09 (m, 1H, H3'), 4.48 (dd, $\left.J=2.6,12.4 \mathrm{~Hz}, 1 \mathrm{H}, \mathrm{H} 5^{\prime}\right), 4.33$ (dd, $J=4.3,12.4 \mathrm{~Hz}, 1 \mathrm{H}, \mathrm{H} 5 "), 5.86$ (d, $J=7.6 \mathrm{~Hz}, 2 \mathrm{H}, \mathrm{H} 5), 6.25$ (t, $J=8.2 \mathrm{~Hz}, 2 \mathrm{H}, \mathrm{H1}$ ), $7.51(\mathrm{~d}, J=7.6 \mathrm{~Hz}, 2 \mathrm{H}, \mathrm{C} 6)$; MS $\left.\left(\mathrm{ESI}^{\dagger}\right) \mathrm{m} / z 534\left(100,[\mathrm{M}+\mathrm{H}]^{\dagger}\right)\right]$ followed by $31(4 \mathrm{mg}$, 
$24 \%)$ of $90 \%$ purity. Compound $\mathbf{3 0}(9.5 \mathrm{mg}, 0.018 \mathrm{mmol})$ was dissolved in TFA (1.0 mL) and reaction mixture was stirred at $18{ }^{\circ} \mathrm{C}$. After $5 \mathrm{~h}$, the reaction mixture was diluted with toluene $(2 \mathrm{~mL})$, the volatiles were evaporated, and the residue was co-evaporated with a toluene $(2 \times 1 \mathrm{~mL})$. The resulting residue $(17 \mathrm{mg})$ was then column chromatographed $(1 \% \mathrm{MeOH} / \mathrm{EtOAc})$ to give $31(2.2 \mathrm{mg}, 29 \%$ from $\mathbf{3 0} ; 38 \%$ overall from 24$)$ as a colorless oil: ${ }^{1} \mathrm{H}$ NMR $\left(\mathrm{CD}_{3} \mathrm{OD}\right) \delta 1.30-1.41\left(\mathrm{~m}, 14 \mathrm{H}, 7 \times \mathrm{CH}_{2}\right), 1.50-1.57\left(\mathrm{~m}, 2 \mathrm{H}, \mathrm{CH}_{2}\right)$, 1.58-1.64 (m, 2H, $\left.\mathrm{CH}_{2}\right), 3.39\left(\mathrm{t}, J=7.1 \mathrm{~Hz}, 2 \mathrm{H}, \mathrm{CH}_{2}\right), 3.55\left(\mathrm{t}, J=6.6 \mathrm{~Hz}, 2 \mathrm{H}, \mathrm{CH}_{2}\right), 3.80$ (dd, $\left.J=3.3,12.6 \mathrm{~Hz}, 1 \mathrm{H}, \mathrm{H} 5^{\prime}\right), 3.89$ (td, $J=2.8,8.3 \mathrm{~Hz}, 1 \mathrm{H}, \mathrm{H} 4$ '), 3.95 (br. dd, $J=2.0$, 12.6, 1H, H5"), 4.26 (dt, $\left.J=8.3,12.1 \mathrm{~Hz}, 1 \mathrm{H}, \mathrm{H} 3{ }^{\prime}\right), 5.87$ (d, $\left.J=7.6 \mathrm{~Hz}, 1 \mathrm{H}, \mathrm{H} 5\right), 6.23$ ("t," $J=8.0 \mathrm{~Hz}, 1 \mathrm{H}, \mathrm{H1}$ '), $7.74(\mathrm{~d}, J=7.6 \mathrm{~Hz}, 1 \mathrm{H}, \mathrm{H} 6) ;{ }^{13} \mathrm{C} \mathrm{NMR}\left(\mathrm{CD}_{3} \mathrm{OD}\right) \delta 26.94$, 28.01, 29.97, 30.42, 30.58, 30.63, 30.66, 30.71, 33.67, 41.74, 60.56 (C5'), 63.03, 70.63 (dd, $J=22.0,24.8 \mathrm{~Hz}, \mathrm{C}^{\prime}$ ), 82.23 (dd, $J=3.8,5.0 \mathrm{~Hz}, \mathrm{C} 4$ '), 85.82 (C1), 97.32 (C5), $124.04\left(\mathrm{t}, J=259.8 \mathrm{~Hz}, \mathrm{C} 2{ }^{\prime}\right), 140.77(\mathrm{C} 6), 158.29(\mathrm{C} 2), 165.37(\mathrm{C} 4) ;{ }^{19} \mathrm{~F}$ NMR $\left(\mathrm{CD}_{3} \mathrm{OD}\right)$ $\delta-119.90$ (br. d, $J=239.2 \mathrm{~Hz}, 1 \mathrm{~F}$ ), -118.83 (dd, $J=11.6,239.2 \mathrm{~Hz}, 1 \mathrm{~F}$ ); MS (ESI) $\mathrm{m} / \mathrm{z}$ $434\left(100,[\mathrm{M}+\mathrm{H}]^{+}\right)$; HRMS $\left(\mathrm{ESI}^{+}\right) \mathrm{m} / z$ calcd for $\mathrm{C}_{20} \mathrm{H}_{33} \mathrm{~F}_{2} \mathrm{~N}_{3} \mathrm{NaO}_{5}[\mathrm{M}+\mathrm{Na}]^{+}$456.2280; found 456.2287 .

4- $N$-(p-Toluenosulfonyl)-2'-deoxy-2',2'-difluorocytidine (32). TMSCl $(5.1 \mathrm{~mL})$ was added to a suspension of $\mathbf{1}(600 \mathrm{mg}, 2.0 \mathrm{mmol})$ in anhydrous pyridine $(10 \mathrm{~mL})$ and stirred at ambient temperature under Ar. After 2 h, TsCl (3.8 g, $20.027 \mathrm{mmol})$ was added and the reaction mixture gradually heated to $60^{\circ} \mathrm{C}$ (oil-bath) and kept stirring. After $20 \mathrm{~h}$, volatiles were evaporated under reduced pressure and the resulting residue was treated with $\mathrm{MeOH} / \mathrm{NH}_{3}(10 \mathrm{~mL})$ and stirred at ambient temperature overnight. After $24 \mathrm{~h}$, volatiles were evaporated under reduced pressure and the resulting residue was column 
chromatographed (90\% EtOAc/hexane) to give 32 (808 mg, 96\%) as a white solid: ${ }^{1} \mathrm{H}$ NMR $\left(\mathrm{CD}_{3} \mathrm{OD}\right) \delta 2.42\left(\mathrm{~s}, 3 \mathrm{H}, \mathrm{CH}_{3}\right), 3.78\left(\mathrm{dd}, J=3.4,12.8 \mathrm{~Hz}, 1 \mathrm{H}, \mathrm{H} 5^{\prime}\right), 3.90-3.95(\mathrm{~m}$, 2H, H4', H5"), 4.28 (dt, $J=8.4,12.0 \mathrm{~Hz}, 1 \mathrm{H}, \mathrm{H3}$ '), 6.13 ("dd," $J=5.3,9.5 \mathrm{~Hz}, 1 \mathrm{H}, \mathrm{H1}$ '), $6.65(\mathrm{~d}, J=8.2 \mathrm{~Hz}, 1 \mathrm{H}, \mathrm{H}$ ), 7.36 (d, $J=8.0 \mathrm{~Hz}, 2 \mathrm{H}, \mathrm{Ar}), 7.79$ (d, $J=8.3 \mathrm{~Hz}, 2 \mathrm{H}, \mathrm{Ar})$, $7.99(\mathrm{~d}, J=8.1 \mathrm{~Hz}, 1 \mathrm{H}, \mathrm{H} 6) ;{ }^{13} \mathrm{C} \mathrm{NMR}\left(\mathrm{CD}_{3} \mathrm{OD}\right) \delta 21.43,60.34(\mathrm{C} 5 '), 70.21(\mathrm{dd}, J=$ 18.8, 27.2 Hz, C3'), 82.99 (d, $J=8.4, \mathrm{C} 4$ '), 85.46 (dd, $J=23.9,41.3 \mathrm{~Hz}, \mathrm{C1}$ '), 98.46 (C5), 123.84 (t, $J=258.7 \mathrm{~Hz}, \mathrm{C} 2$ '), 127.58 (Ar), 130.52 (Ar), 140.71 (Ar), 142.62 (C6), 144.66 (Ar), $150.21(\mathrm{C} 2), 160.54(\mathrm{C} 4) ;{ }^{19} \mathrm{~F} \mathrm{NMR}\left(\mathrm{CD}_{3} \mathrm{OD}\right) \delta-120.17$ (br. s, $\left.1 \mathrm{~F}\right),-119.41$ (dd, $J=$ 4.1, $12.7 \mathrm{~Hz}, 1 \mathrm{~F}) ; \mathrm{MS}\left(\mathrm{ESI}^{+}\right) \mathrm{m} / z 440\left(100,[\mathrm{M}+\mathrm{Na}]^{+}\right.$. HRMS $\left(\mathrm{ESI}^{+}\right) \mathrm{m} / z$ calcd for $\mathrm{C}_{16} \mathrm{H}_{17} \mathrm{~F}_{2} \mathrm{~N}_{3} \mathrm{NaO}_{6} \mathrm{~S}[\mathrm{M}+\mathrm{Na}]^{+} 440.0698$; found 440.0711 .

4- $N$-(11-Benzyloxyundecanyl)-2'-deoxy-2',2'-difluorocytidine (33). In a tightly sealed container, a solution of 55 (158 $\mathrm{mg}, 0.383 \mathrm{mmol}), 11$-(benzyloxy)undecanyl amine (70; $945 \mathrm{mg}, 3.41 \mathrm{mmol})$ and TEA $(2 \mathrm{~mL})$ in 1,4-dioxane was stirred at $75^{\circ} \mathrm{C}$. After $96 \mathrm{~h}$, the volatiles were evaporated under reduced pressure and the resulting residue was column chromatographed (1\% MeOH/EtOAc) to give $33(122 \mathrm{mg}, 61 \%):{ }^{1} \mathrm{H}$ NMR $\left(\mathrm{CD}_{3} \mathrm{OD}\right) \delta 1.28$ (br. s, $10 \mathrm{H}, 5 \times \mathrm{CH}_{2}$ ), 1.32 (br. s, $4 \mathrm{H}, 2 \mathrm{x} \mathrm{CH}_{2}$ ), 1.54-1.61 (m, $4 \mathrm{H}, 2 \mathrm{x}$ $\mathrm{CH}_{2}$ ), $3.36\left(\mathrm{t}, \mathrm{J}=7.1 \mathrm{~Hz}, 2 \mathrm{H}, \mathrm{CH}_{2}\right), 3.47\left(\mathrm{t}, J=6.6 \mathrm{~Hz}, 2 \mathrm{H}, \mathrm{CH}_{2}\right), 3.79(\mathrm{dd}, J=3.3,12.6$, 1H, H5'), 3.88-3.96 (m, 2H, H4', H5"), 4.25 (dt, $J=8.3,12.0 \mathrm{~Hz}, 1 \mathrm{H}, \mathrm{H} 3$ '), 4.48 (s, 2H, $\mathrm{CH}_{2}$ ), 5.89 (d, $\left.J=7.6 \mathrm{~Hz}, 1 \mathrm{H}, \mathrm{H} 5\right), 6.21$ (t, $J=8.0 \mathrm{~Hz}, 1 \mathrm{H}, \mathrm{H1}$ ), 7.32 ("br. s," 5H, Ar), $7.70(\mathrm{~d}, J=7.6 \mathrm{~Hz}, 1 \mathrm{H}, \mathrm{H} 6) ;{ }^{13} \mathrm{C} \mathrm{NMR}\left(\mathrm{CD}_{3} \mathrm{OD}\right) \delta 27.23,28.00,29.96,30.42,30.48$, 30.60, 30.63, 30.65, 30.71, 41.74, 60.54, 68.14 (C3'), 71.44, 73.86, 82.24 ("t," $J=2.95$ Hz, C4'), 85.92 ("dd," $J=26.7,37.7$ Hz, C1'), 97.31 (C5), 124.04 (t, $J=258.7$ Hz, C2'), $128.62,128.84,129.35,139.87,140.75,158.27,165.34 ;{ }^{19} \mathrm{~F}$ NMR $\left(\mathrm{CD}_{3} \mathrm{OD}\right) \delta-119.47$ 
(br. d, $J=236.7 \mathrm{~Hz}, 1 \mathrm{~F}),-118.42(\mathrm{dd}, J=8.6,236.7 \mathrm{~Hz}, 1 \mathrm{~F})$; HRMS $\left(\mathrm{ESI}^{+}\right) m / z$ calcd for $\mathrm{C}_{27} \mathrm{H}_{39} \mathrm{~F}_{2} \mathrm{~N}_{3} \mathrm{NaO}_{5}[\mathrm{M}+\mathrm{Na}]^{+}$546.2750; found 546.2774.

\section{4- $N$-(11-Benzyloxyundecanyl)-3',5'-di-O-benzoyl-2'-deoxy-2',2'-difluorocytidine}

(34). $\mathrm{BzCl}(50 \mu \mathrm{L}, 0.49 \mathrm{mmol})$ was added to a solution of $\mathbf{3 3}(117 \mathrm{mg}, 0.22 \mathrm{mmol}), 2,6-$

Lutidine $(64 \mu \mathrm{L}, 0.89 \mathrm{mmol})$ and 4-dimethylaminopyridine $(27 \mathrm{mg}, 0.22 \mathrm{mmol})$ in $\mathrm{CH}_{2} \mathrm{Cl}_{2}(10 \mathrm{~mL})$ and stirred at $35{ }^{\circ} \mathrm{C}$ under Argon. After $20 \mathrm{~h}$, the reaction mixture was

diluted with $\mathrm{CH}_{2} \mathrm{Cl}_{2}(40 \mathrm{~mL})$, partitioned with $\mathrm{H}_{2} \mathrm{O}$, and the aqueous layer extracted with $\mathrm{CH}_{2} \mathrm{Cl}_{2}(2 \times 20 \mathrm{~mL})$. The combined organic layer was sequentially washed with $1 \mathrm{M} \mathrm{HCl}$ $(20 \mathrm{~mL})$, saturated $\mathrm{NaHCO}_{3} / \mathrm{H}_{2} \mathrm{O}(20 \mathrm{~mL})$ and brine $(20 \mathrm{~mL})$, dried over $\mathrm{Na}_{2} \mathrm{SO}_{4}$, evaporated under reduced pressure and the resulting residue $(157 \mathrm{mg})$ was column chromatographed $\left(1 \% \mathrm{MeOH} / \mathrm{CHCl}_{3}\right)$ to give $34(50.6 \mathrm{mg}, 60 \%)$ as a mixture of rotamers (80:20). The major rotamer had the following peaks: ${ }^{1} \mathrm{H}$ NMR $\left(\mathrm{CD}_{3} \mathrm{OD}\right) \delta 1.24$ (br. s, $\left.12 \mathrm{H}, 6 \times \mathrm{CH}_{2}\right), 1.51-1.62\left(\mathrm{~m}, 4 \mathrm{H}, 2 \times \mathrm{CH}_{2}\right), 3.20\left(\mathrm{t}, J=7.1 \mathrm{~Hz}, 2 \mathrm{H}, \mathrm{CH}_{2}\right), 3.39(\mathrm{t}, J=$ $12.3 \mathrm{~Hz}, 2 \mathrm{H}, \mathrm{CH}_{2}$ ), 4.48 (s, 2H, $\mathrm{CH}_{2}$ ), 4.49-4.53 (m, 1H, H5'), 4.63-4.67 (m, 1H, H5'), 4.73-4.79 (m, 1H, H4'), 5.54 (d, $J=7.6 \mathrm{~Hz}, 1 \mathrm{H}, \mathrm{H} 5), 5.57-5.61$ (m, 1H, H3'), 6.60-6.65 (m, 1H, H1'), 7.26-7.33 (m, 5H, Ar), 7.41-7.49 (m, 4H, Ar), 7.55-7.64 (m, 2H, Ar), 8.028.08 (m, 4H, Ar); ${ }^{19} \mathrm{~F} \mathrm{NMR}\left(\mathrm{CD}_{3} \mathrm{OD}\right) \delta-120.48$ (br. d, $\left.J=246.7 \mathrm{~Hz}, 1 \mathrm{~F}\right),-115.34$ (dt, $J=$ 13.6, $246.7 \mathrm{~Hz}, 1 \mathrm{~F})$; MS $\left(\mathrm{ESI}^{+}\right) \mathrm{m} / z 754\left(100,[\mathrm{M}+\mathrm{Na}]^{+}\right.$. HRMS $\left(\mathrm{ESI}^{+}\right) m / z$ calcd for $\mathrm{C}_{41} \mathrm{H}_{47} \mathrm{~F}_{2} \mathrm{~N}_{3} \mathrm{NaO}_{7}[\mathrm{M}+\mathrm{Na}]^{+}$754.3274; found 754.3303.

The minor rotamer had the following distinguishable peaks: ${ }^{1} \mathrm{H}$ NMR $\left(\mathrm{CD}_{3} \mathrm{OD}\right) \delta$ $5.70(\mathrm{~d}, J=7.8,1 \mathrm{H}, \mathrm{H} 5) ;{ }^{19} \mathrm{~F}$ NMR $\left(\mathrm{CD}_{3} \mathrm{OD}\right): \delta-115.82(\mathrm{dt}, J=13.4,246.7,1 \mathrm{~F})$.

\section{4- $N$-(11-Hydroxyundecanyl)-3',5'-di-O-benzoyl-2'-deoxy-2',2'-difluorocytidine}

(35). Ammonium cerium (IV) nitrate (63 $\mathrm{mg}, 0.115 \mathrm{mmol}$ ) was added to a solution of $\mathbf{3 4}$ 
(106 mg, $0.145 \mathrm{mmol})$ in $\mathrm{CH}_{3} \mathrm{CN}: \mathrm{H}_{2} \mathrm{O}(9: 1,5 \mathrm{~mL})$ and stirred at ambient temperature overnight. Additional portions of CAN $(240 \mathrm{mg})$ were added to the reaction mixture every $24 \mathrm{~h}$ until no starting material could be detected by TLC. After $72 \mathrm{~h}$, the reaction was quenched by the addition of saturated $\mathrm{NaHSO}_{3}(20 \mathrm{~mL})$, the volatiles evaporated under reduced pressure and the resulting aqueous residue was extracted with EtOAc ( $3 \mathrm{x}$ $20 \mathrm{~mL}$ ). The combined organic layer was washed with brine $(20 \mathrm{~mL})$, dried over $\mathrm{Na}_{2} \mathrm{SO}_{4}$, evaporated under reduced pressure and the resulting residue $(103.5 \mathrm{mg})$ was then column chromatographed (1\% MeOH/EtOAc) to give $35(66 \mathrm{mg}, 70 \%)$ as a mixture of rotamers (72:28). The major rotamer had the following peaks: ${ }^{1} \mathrm{H}$ NMR $\left(\mathrm{CD}_{3} \mathrm{OD}\right) \delta 1.24$ (br. s, $\left.14 \mathrm{H}, 7 \times \mathrm{CH}_{2}\right), 1.51-1.64\left(\mathrm{~m}, 4 \mathrm{H}, 2 \times \mathrm{CH}_{2}\right), 3.20\left(\mathrm{t}, J=7.0 \mathrm{~Hz}, 2 \mathrm{H}, \mathrm{CH}_{2}\right), 3.63(\mathrm{t}, J=6.6$ $\left.\mathrm{Hz}, 2 \mathrm{H}, \mathrm{CH}_{2}\right), 4.50-4.58$ (m, 1H, H4'), 4.64-4.71 (m, 1H, H5'), 4.75-4.82 (m, 1H, H5"), 5.57-5.62 (m, 1H, H3') 5.60 (d, $J=7.6 \mathrm{~Hz}, 1 \mathrm{H}, \mathrm{H} 5), 6.58-6.61$ (m, 1H, H1'), 7.31 ("d," $J$ $=7.6 \mathrm{~Hz}, 1 \mathrm{H}, \mathrm{H} 6), 7.41-7.65(\mathrm{~m}, 6 \mathrm{H}, \mathrm{Ar}), 8.02-8.11(\mathrm{~m}, 4 \mathrm{H}, \mathrm{Ar}) ;{ }^{13} \mathrm{C} \mathrm{NMR}\left(\mathrm{CDCl}_{3}\right) \delta$ $25.79,26.93,29.20,29.29,29.44,29.47,29.53,29.57,32.78,41.14,62.90,63.01,71.86$ (m, C3'), 77.74 (C4'), 83.51 (br. s, C1'), 96.55 (C5), 120.98 (t, $J=256.3 \mathrm{~Hz}, \mathrm{C} 2$ '), 128.10, $128.70,128.81,129.39,129.81,130.27,133.60,134.28,139.86,155.75,163.59,165.05$, 166.09; ${ }^{19} \mathrm{~F}$ NMR $\delta-115.36(\mathrm{dt}, J=13.7,246.3 \mathrm{~Hz}, 1 \mathrm{~F}),-120.50$ (br. d, 1F); MS $\left(\mathrm{ESI}^{+}\right)$ $m / z 664\left(100,[\mathrm{M}+\mathrm{Na}]^{+}\right.$; HRMS $\left(\mathrm{ESI}^{+}\right) \mathrm{m} / z$ calcd for $\mathrm{C}_{34} \mathrm{H}_{41} \mathrm{~F}_{2} \mathrm{~N}_{3} \mathrm{NaO}_{7}[\mathrm{M}+\mathrm{Na}]^{+}$ 664.2805; found 664.2837.

The minor rotamer had the following distinguishable peaks: ${ }^{1} \mathrm{H}$ NMR $(400 \mathrm{MHz}$, $\left.\mathrm{CDCl}_{3}\right) \delta 3.40-3.41\left(\mathrm{~m}, 2 \mathrm{H}, \mathrm{CH}_{2}\right), 5.71(\mathrm{~d}, J=7.8 \mathrm{~Hz}, 1 \mathrm{H}, \mathrm{H} 5) ;{ }^{19} \mathrm{~F}$ NMR $\delta-115.85$ (dt, $J$ $=12.4,246.0 \mathrm{~Hz}, 1 \mathrm{~F})$. 


\section{5,6-dihydro-4- $N$-(11-Hydroxyundecanyl)-3',5'-O-di-benzoyl-2'-deoxy-2',2'-}

difluorocytidine (36). A flask containing a solution of $\mathbf{3 4}(40.5 \mathrm{mg}, 0.055 \mathrm{mmol})$ and $5 \%$ Pd-C in EtOH was equipped with a $\mathrm{H}_{2}$ gas balloon and stirred at ambient temperature overnight. After $15 \mathrm{~h}$, the reaction mixture (which still contained active Pd-C) was filtered, the volatiles evaporated under reduced pressure and the resulting residue (36.4 $\mathrm{mg}$ ) column chromatographed (1\% MeOH/EtOAc) to give $36(6.1 \mathrm{mg}, 25 \%)$ as a clear oil: $\mathrm{MS}\left(\mathrm{ESI}^{+}\right) \mathrm{m} / z 643\left(100,[\mathrm{M}+\mathrm{Na}]^{+}\right.$.

\section{4- $N$-[11-(Methanesulfoxy)undecanyl]-3',5'-di-O-benzoyl-2'-deoxy-2',2'-}

difluorocytidine (37). $\mathrm{Et}_{3} \mathrm{~N}(3.8 \mu \mathrm{L}, 2.7 \mathrm{mg}, 0.027 \mathrm{mmol})$ and $\mathrm{MsCl}(1.5 \mu \mathrm{L}, 2.3 \mathrm{mg}$, $0.020 \mathrm{mmol})$ were sequentially added to a stirred solution of $\mathbf{3 5}(11.6 \mathrm{mg}, 0.018 \mathrm{mmol})$ in $\mathrm{CH}_{2} \mathrm{Cl}_{2}$ at $0{ }^{\circ} \mathrm{C}$. After 5 minutes, the reaction mixture was allowed to warm up to ambient temperature and kept stirring. After $3 \mathrm{~h}$, the reaction mixture was then partitioned between $\mathrm{H}_{2} \mathrm{O}$ and $\mathrm{CH}_{2} \mathrm{Cl}_{2}$, and the aqueous layer then extracted with $\mathrm{CH}_{2} \mathrm{Cl}_{2}(2 \times 20 \mathrm{~mL})$. The combined organic layer was washed with brine, dried over $\mathrm{MgSO}_{4}$, evaporated under reduced pressure and the resulting residue $(12.1 \mathrm{mg})$ was column chromatogramphed (50\% EtOAc/hexane) to give $37(11.7 \mathrm{mg}, 90 \%)$ as a mixture of rotamers $(71: 29)$. The

major rotamer had the following peaks: ${ }^{1} \mathrm{H}$ NMR $\left(\mathrm{CDCl}_{3}\right) \delta 1.25$ (br.s, $\left.14 \mathrm{H}, 7 \times \mathrm{CH}_{2}\right)$, 1.55-1.77 (m, 4H, $\left.2 \times \mathrm{CH}_{2}\right), 2.99\left(\mathrm{~s}, 3 \mathrm{H}, \mathrm{CH}_{3}\right), 3.46-3.52\left(\mathrm{~m}, 2 \mathrm{H}, \mathrm{CH}_{2}\right), 4.21(\mathrm{t}, J=6.6$ $\left.\mathrm{Hz}, 2 \mathrm{H}, \mathrm{CH}_{2}\right), 4.51-4.58$ (m, 1H, H4'), 4.64-4.81 (m, 2H, H5', H5"), 5.55 (d, $J=7.6 \mathrm{~Hz}$, 1H, H5), 5.59-5.63 (m, 1H, H3'), 6.55-6.67 (m, 1H, H1'), 7.32 (dd, $J=1.6,7.5 \mathrm{~Hz}, 1 \mathrm{H}$, H6), 7.43-7.51 (m, 4H, Ar), 7.57-7.66 (m, 2H, Ar), 8.03-8.10 (m, 4H, Ar); ${ }^{13} \mathrm{C}$ NMR $\left(\mathrm{CDCl}_{3}\right) \delta 21.15,25.47,26.94,29.00,29.22,29.30,29.39,29.46,29.55,37.50,41.18$ 63.02 (C5'), 70.39, 71.96 ("dd," $J=17.3,35.8 \mathrm{~Hz}, \mathrm{C} 3$ '), 77.36 (C4'), 84.00 (br. s, C1'), 
96.22 (C5), 120.93 (t, $J=262.8 \mathrm{~Hz}, \mathrm{C} 2$ '), 128.13, 128.71, 128.82, 129.41, 129.82, 130.28, 133.61, 134.28, 139.97 (C6), 155.66, 163.55, 165.05, 166.08; ${ }^{19} \mathrm{~F}$ NMR $\delta-120.61$ (br.d, $J=261.9 \mathrm{~Hz}, 1 \mathrm{~F}),-115.38(\mathrm{dt}, J=14.1,246.7 \mathrm{~Hz}, 1 \mathrm{~F})$; MS (ESI) $m / z 720(100$, $\left.[\mathrm{M}+\mathrm{H}]^{+}\right)$; HRMS $\left(\mathrm{ESI}^{+}\right) \mathrm{m} / z$ calcd for $\mathrm{C}_{35} \mathrm{H}_{43} \mathrm{~F}_{2} \mathrm{~N}_{3} \mathrm{NaO}_{9} \mathrm{~S}[\mathrm{M}+\mathrm{Na}]^{+}$742.2580; found 742.2603 .

The minor rotamer had the following distinguishable peaks: ${ }^{1} \mathrm{H}$ NMR $\left(\mathrm{CDCl}_{3}\right) \delta 3.23$ $3.25\left(\mathrm{~m}, \mathrm{CH}_{2} \mathrm{~N}\right), 5.77(\mathrm{~d}, J=7.9 \mathrm{~Hz}, \mathrm{H} 5) ;{ }^{19} \mathrm{~F}$ NMR $\delta-115.98(\mathrm{dt}, J=13.1,234.1 \mathrm{~Hz}$, $1 \mathrm{~F})$.

\section{4- $N$-(11-Fluoroundecanyl)-3',5'-di-O-benzoyl-2'-deoxy-2',2'-difluorocytidine}

(38). A chilled $\left(-78^{\circ} \mathrm{C}\right)$ solution of DAST $(14 \mu \mathrm{L}, 17.2 \mathrm{mg}, 0.107 \mathrm{mmol})$ in $\mathrm{CH}_{2} \mathrm{Cl}_{2}(250$ $\mu \mathrm{L})$ was added to a stirred solution of $\mathbf{3 5}(21.7 \mathrm{mg}, 0.034 \mathrm{mmol})$ in $\mathrm{CH}_{2} \mathrm{Cl}_{2}(1 \mathrm{~mL})$ at -78 ${ }^{\circ} \mathrm{C}$. After 30 minutes, the reaction mixture was allowed to warm up to ambient temperature and kept stirring. After $3 \mathrm{~h}$, the reaction mixture was poured into a separatory funnel containing a ice-cold solution of $\mathrm{Na}_{2} \mathrm{HCO}_{3}$ in $\mathrm{H}_{2} \mathrm{O}(10 \mathrm{~mL}, \mathrm{pH}=8)$ and was extracted with $\mathrm{CHCl}_{3}(3 \times 10 \mathrm{~mL})$. The combined organic layer was washed with brine, dried over $\mathrm{MgSO}_{4}$, evaporated under reduced pressure and the resulting oily residue (20.5 $\mathrm{mg}$ ) was then column chromatographed (40\% EtOAc/hexane) to give $\mathbf{3 8}(10.6 \mathrm{mg}, 48 \%)$ as a mixture of rotamers (76:24). The major rotamer had the following peaks: ${ }^{1} \mathrm{H}$ NMR $\left(\mathrm{CDCl}_{3}\right) \delta 1.27$ (br. s, $\left.14 \mathrm{H}, 7 \times \mathrm{CH}_{2}\right), 1.55-1.69\left(\mathrm{~m}, 4 \mathrm{H}, 2 \times \mathrm{CH}_{2}\right), 3.47-3.52(\mathrm{~m}, 2 \mathrm{H}$, $\mathrm{CH}_{2}$ ), 4.43 (dt, $J=6.2,47.4 \mathrm{~Hz}, 2 \mathrm{H}, \mathrm{CH}_{2}$ ), 4.51-4.55 (m, 1H, H4'), 4.67 (dd, $J=4.5,12.3$ Hz, 1H, H5'), 4.79 (dd, $J=3.2,12.3 \mathrm{~Hz}, 1 \mathrm{H}, \mathrm{H} 5 "), 5.54$ (d, $J=7.6 \mathrm{~Hz}, 1 \mathrm{H}, \mathrm{H} 5), 5.58-$ 5.63 (m, 1H, H3'), 6.61 (br.s, 1H, H1'), 7.32 (d, $J=7.5 \mathrm{~Hz}, 1 \mathrm{H}, \mathrm{H} 6), 7.42-7.66$ (m, 6H, Ar), 8.03-8.16 (m, 4H, Ar); ${ }^{13} \mathrm{C} \mathrm{NMR}\left(\mathrm{CDCl}_{3}\right) \delta 25.30,27.01,29.24,29.32,29.49,29.56$, 
29.83, 30.44, 30.63, 41.28, 63.02 (C5'), 71.87 (br. s, C3'), 79.16 (br. s, C4'), 83.56 (br. s, C1'), 84.37 (d, $\left.J=164.0 \mathrm{~Hz}^{\prime}\right), 96.17$ (C5), 121.88 (t, $J=255.7 \mathrm{~Hz}, \mathrm{C} 2$ '), 128.14, 128.73, $128.84,129.43,129.84,130.31,133.59,134.29,140.10,155.46,163.39,165.06,166.10$

${ }^{19} \mathrm{~F} \mathrm{NMR}\left(\mathrm{CDCl}_{3}\right) \delta-217.94(\mathrm{tt}, \mathrm{J}=24.9,47.3 \mathrm{~Hz}, 1 \mathrm{~F}),-120.62$ (br. d, $\left.J=203.1,1 \mathrm{~F}\right)$, $115.40(\mathrm{dt}, J=14.1,247.3 \mathrm{~Hz}, 1 \mathrm{~F})$; MS (ESI) $m / z 644\left(100,[\mathrm{M}+\mathrm{H}]^{+}\right)$; HRMS (ESI$\mathrm{TOF}^{+}$) $\mathrm{m} / z$ calcd for $\mathrm{C}_{34} \mathrm{H}_{40} \mathrm{~F}_{3} \mathrm{~N}_{3} \mathrm{NaO}_{6}[\mathrm{M}+\mathrm{Na}]^{+}$666.2761; found 666.2763 .

The minor rotamer had the following distinguishable peaks: ${ }^{1} \mathrm{H}$ NMR $(400 \mathrm{MHz}$, $\left.\mathrm{CDCl}_{3}\right) \delta 3.20-3.21\left(\mathrm{~m}, 2 \mathrm{H}, \mathrm{CH}_{2} \mathrm{~N}\right), 5.71(\mathrm{~d}, J=7.8 \mathrm{~Hz}, 1 \mathrm{H}, \mathrm{H} 5) ;{ }^{19} \mathrm{~F} \mathrm{NMR} \delta-115.98(\mathrm{dt}$, $J=12.9,247.5 \mathrm{~Hz}, 1 \mathrm{~F})$

4-N-(11-Fluoroundecanyl)-2'-deoxy-2',2'-difluorocytidine (39). Method $A$. Compound 38 (10.6 mg, $0.017 \mathrm{mmol})$ was dissolved in methanolic ammonia $(2 \mathrm{~mL})$ and stirred at ambient temperature. After $2 \mathrm{~h}$, volatiles were evaporated under reduced pressure and the resulting residue was chromatographed (5\% MeOH/EtOAc) to give 39 (6.5 mg, 90\%) as a clear oil: ${ }^{1} \mathrm{H}$ NMR $\left(\mathrm{CD}_{3} \mathrm{OD}\right) \delta 1.32$ (br.s, $\left.14 \mathrm{H}, 7 \times \mathrm{CH}_{2}\right), 1.55-1.73$ (m, 4H, $2 \times \mathrm{CH}_{2}$ ), 3.37 (t, $J=7.1 \mathrm{~Hz}, 2 \mathrm{H}, \mathrm{CH}_{2}$ ), 3.78 (dd, $\left.J=3.3,12.6 \mathrm{~Hz}, 1 \mathrm{H}, \mathrm{H} 5^{\prime}\right), 3,87$ (dt, $J=3.0,8.28 \mathrm{~Hz}, 1 \mathrm{H}, \mathrm{H} 3$ '), 3.93 ('d', $J=13.3 \mathrm{~Hz}, 1 \mathrm{H}, \mathrm{H} 5 "), 4.20-4.28$ (m, 1H, H4'), $4.40\left(\mathrm{dt}, J=6.1,47.6 \mathrm{~Hz}, 1 \mathrm{H}, \mathrm{CH}_{2}\right), 5.85$ (d, $\left.J=7.6 \mathrm{~Hz}, 1 \mathrm{H}, \mathrm{H} 5\right), 6.21$ ("t", $J=7.96 \mathrm{~Hz}$, H1'), 7.73 (d, $J=7.6 \mathrm{~Hz}, 1 \mathrm{H}, \mathrm{H} 6$ ); ${ }^{19} \mathrm{~F}$ NMR $\delta-219.94$ (tt, $J=25.5,47.3 \mathrm{~Hz}, 1 \mathrm{~F}, \mathrm{CH}_{2} \mathrm{~F}$ ), -119.60 (br. s, 1F), -119.14 (br. s, 1F); MS (ESI) $m / z 436\left(100,[\mathrm{M}+\mathrm{H}]^{+}\right)$; HRMS (ESI ${ }^{+}$) $m / z$ calcd for $\mathrm{C}_{20} \mathrm{H}_{32} \mathrm{~F}_{3} \mathrm{~N}_{3} \mathrm{NaO}_{4}[\mathrm{M}+\mathrm{Na}]^{+} 458.2237$; found 458.2256 .

Method B. In a tightly sealed cylindrical pressure vessel with screw cap, a solution of $\mathrm{KF}(1.6 \mathrm{mg}, 0.028 \mathrm{mmol}), \mathrm{K}_{2} \mathrm{CO}_{3}(3.8 \mathrm{mg}, 0.028 \mathrm{mmol})$, Kryptofix $2.2 .2(10.5 \mathrm{mg}, 0.028$ mmol) and $37(5.0 \mathrm{mg}, 0.007 \mathrm{mmol})$ in $\mathrm{CH}_{3} \mathrm{CN}(1 \mathrm{~mL})$ was stirred at $110^{\circ} \mathrm{C}$. After 18 
min, the reaction mixture was quickly cooled in a water bath and vacuum filtrated into another pressure vessel. The effluent containing crude $\mathbf{3 8}$ was concentrated under reduced pressure and the resulting residue treated with $0.5 \mathrm{CH}_{3} \mathrm{ONa} / \mathrm{MeOH}(1 \mathrm{~mL})$, then stirred and heated at $100{ }^{\circ} \mathrm{C}$. After 8 min, the reaction mixture was neutralized with $1 \mathrm{~N} \mathrm{HCl}$ and evaporated under reduced pressure to dryness. The crude sample was then dissolved in $45 \% \mathrm{CH}_{3} \mathrm{CN} / \mathrm{H}_{2} \mathrm{O}$ to a total volume of $4.5 \mathrm{~mL}$, passed through a $0.2 \mu \mathrm{m}$ PTFE syringe filter and then injected into a semi-preparative HPLC column (Phenomenex Gemini RP$\mathrm{C} 18$ column; $5 \mu, 25 \mathrm{~cm} \mathrm{X} 1 \mathrm{~cm}$ ) via $5 \mathrm{~mL}$ loop. The HPLC column was eluted with an isocratic mobile phase mixture $45 \% \mathrm{CH}_{3} \mathrm{CN} / \mathrm{H}_{2} \mathrm{O}$ at a flow rate $=5 \mathrm{~mL} / \mathrm{min}$ to give 39 $\left(1.9 \mathrm{mg}, 62 \%\right.$ overall yield from $\left.37, t_{\mathrm{R}}=13.1 \mathrm{~min}\right)$ with data as reported above.

\section{4- $N$-[4-(4,7-Bis(2-tert-butoxy-2-oxoethyl)-1,4,7-triazonan-1-yl)-5-tert-butoxy-} 5-oxopentanoyl]-2'-deoxy-2',2'-difluorocytidine (40). Compound 1 (12.6 mg, 0.042 mmol) was treated with commercially available 4-(4,7-bis(2-(tert-butoxy)-2-oxoethyl)1,4,7-triazacyclononan-1-yl)-5-(tert-butoxy)-5-oxopentanoic acid (25 mg, $0.046 \mathrm{mmol}$ ) according to coupling conditions from Procedure. After 20h, the reaction mixture was treated with $\mathrm{H}_{2} \mathrm{O}$ and $\mathrm{EtOH}$, the volatiles evaporated under reduced pressure and the resulting residue ( $75 \mathrm{mg}$ ) diluted with a solution of $95 \% \mathrm{H}_{2} \mathrm{O} / \mathrm{CH}_{3} \mathrm{CN}$ to a total volume of $1.5 \mathrm{~mL}$, passed through a $0.2 \mu \mathrm{m}$ PTFE syringe filter and then injected into a preparative HPLC column (XTerra Prep RP-C18 column; $5 \mu, 19$ X $150 \mathrm{~mm}$ ) via $2 \mathrm{~mL}$ loop. The HPLC column was eluted with a gradient program (isocratic mobile phase mixture 95\% $\mathrm{H}_{2} \mathrm{O} / \mathrm{CH}_{3} \mathrm{CN}$ for 60 min, gradient $95 \rightarrow 0 \% \mathrm{H}_{2} \mathrm{O} / \mathrm{CH}_{3} \mathrm{CN}$ over $30 \mathrm{~min}$ ) at a flow rate $=$ $2.5 \mathrm{~mL} / \mathrm{min}$, to give 40 with $\mathrm{R}_{\mathrm{t}}=98-129 \mathrm{~min}$ ( $3.4 \mathrm{mg}, 10 \%$ yield) as a clear oil: MS (ESI) $m / z 789\left(100,[\mathrm{M}+\mathrm{H}]^{+}\right)$. 


\section{4- $N$-[4-(4,7-Bis(carboxymethyl)-1,4,7-triazonan-1-yl)-4-carboxybutanoyl]-2'-}

deoxy-2',2'-difluorocytidine (41). Compound 40 (3.4 mg, $0.004 \mathrm{mmol})$ was dissolved in TFA $(1.0 \mathrm{~mL})$ and the mixture was stirred at ambient temperature overnight. After $15 \mathrm{~h}$, the reaction mixture was diluted with toluene, the volatiles were evaporated, and the residue co-evaporated with a fresh portion of toluene. The resulting residue was then dissolved with a solution of $95 \% \mathrm{H}_{2} \mathrm{O} / \mathrm{CH}_{3} \mathrm{CN}$ to a total volume of $1.5 \mathrm{~mL}$, passed through a $0.2 \mu \mathrm{m}$ PTFE syringe filter and then injected into a preparative HPLC column (XTerra Prep RP-C18 column; $5 \mu, 19$ X $150 \mathrm{~mm}$ ) via $2 \mathrm{~mL}$ loop. The HPLC column was eluted with a gradient program (isocratic mobile phase mixture $95 \% \mathrm{H}_{2} \mathrm{O} / \mathrm{CH}_{3} \mathrm{CN}$ for 60 min, gradient $95 \rightarrow 0 \% \mathrm{H}_{2} \mathrm{O} / \mathrm{CH}_{3} \mathrm{CN}$ over $30 \mathrm{~min}$ ) at a flow rate $=2.5 \mathrm{~mL} / \mathrm{min}$, to give 41 with $\mathrm{R}_{\mathrm{t}}=63-70 \mathrm{~min}(1.0 \mathrm{mg}, 37 \%$ yield) as a clear oil: MS (ESI) $\mathrm{m} / z 621$ (100, $\left.[\mathrm{M}+\mathrm{H}]^{+}\right)$.

4- $N$-[ $N^{\prime}$-Boc-(3-aminopropanoyl)-2'-deoxy-2',2'-difluorocytidine (43). Treatment of 1 (42 mg, $0.140 \mathrm{mmol})$ with commercially available $N$-Boc- $\beta$-alanine $(29.2 \mathrm{mg}, 0.154$ mmol) by Procedure A gave $46.4 \mathrm{mg}$ of the crude product, which was then column chromatographed (5\% MeOH/EtOAc) to give $43(40.1 \mathrm{mg}, 65 \%)$ as a white solid: ${ }^{1} \mathrm{H}$ $\operatorname{NMR}\left(\mathrm{CD}_{3} \mathrm{OD}\right) \delta 1.42\left(\mathrm{~s}, 9 \mathrm{H}, 3 \times \mathrm{CH}_{3}\right), 2.63\left(\mathrm{t}, J=6.5 \mathrm{~Hz}, 2 \mathrm{H}, \mathrm{CH}_{2}\right), 3.37(\mathrm{t}, J=6.5 \mathrm{~Hz}$, 2H, $\mathrm{CH}_{2}$ ), 3.81 (dd, $J=3.2,12.8 \mathrm{~Hz}, 1 \mathrm{H}, \mathrm{H} 5$ '), 3.95-3.99 (m, 2H, H4', H5"), 4.30 (m, 1H, H3'), 6.26 (t, $J=7.3 \mathrm{~Hz}, 1 \mathrm{H}, \mathrm{H1}$ ), 7.49 (d, $J=7.6 \mathrm{~Hz}, 1 \mathrm{H}, \mathrm{H} 5), 8.33$ (d, $J=7.6 \mathrm{~Hz}, 1 \mathrm{H}$, H6); ${ }^{19} \mathrm{~F} \mathrm{NMR}\left(\mathrm{CD}_{3} \mathrm{OD}\right) \delta-121.01$ (br. d, $\left.J=237.0 \mathrm{~Hz}, 1 \mathrm{~F}\right),-119.16$ (dd, $J=243.4,12.1$ $\mathrm{Hz}, 1 \mathrm{~F}) ; \mathrm{MS}^{\left(\mathrm{ESI}^{+}\right)} m / z 435\left(100,[\mathrm{M}+\mathrm{H}]^{+}\right)$.

4- $N$-[N'-Boc-(3-aminopropanyl)-2'-deoxy-2',2'-difluorocytidine (45). In a tightly sealed vessel, a mixture of $\mathbf{2 4}(11.5 \mathrm{mg}, 0.018 \mathrm{mmol})$ and commercially available $N$-Boc- 
1,3-propanediamine $(150 \mu \mathrm{L}, 150 \mathrm{mg}, 0.86 \mathrm{mmol})$ was stirred at $65^{\circ} \mathrm{C}$. After $48 \mathrm{~h}$, the volatiles were evaporated the resulting residue was column chromatographed $(30 \%$ EtOAc/hexane $\rightarrow 5 \% \quad \mathrm{MeOH} / \mathrm{EtOAc})$ to give fully protected $4-\mathrm{N}$-[N-Boc-(3aminopropanyl)-gemcitabine [3.6 mg, 31\% MS $\left(\mathrm{ESI}^{+}\right) \mathrm{m} / z$ $\left.621\left(100,[\mathrm{M}+\mathrm{H}]^{+}\right)\right]$followed by 45 (3.5 mg, 59\%) as colorless oil: ${ }^{1} \mathrm{H}$ NMR $\left(\mathrm{CD}_{3} \mathrm{OD}\right) \delta 1.43\left(\mathrm{~s}, 9 \mathrm{H}, 3 \times \mathrm{CH}_{3}\right), 1.74$ (quin, $\left.J=6.8 \mathrm{~Hz}, 2 \mathrm{H}, \mathrm{CH}_{2}\right), 3.10\left(\mathrm{t}, J=6.7 \mathrm{~Hz}, 2 \mathrm{H}, \mathrm{CH}_{2}\right), 3.41\left(\mathrm{t}, J=6.9 \mathrm{~Hz}, 2 \mathrm{H}, \mathrm{CH}_{2}\right)$, 3.77 (dd, $\left.J=3.2,12.6 \mathrm{~Hz}, 1 \mathrm{H}, \mathrm{H} 5^{\prime}\right), 3.87$ (dt, $J=2.8,8.3 \mathrm{~Hz}, 1 \mathrm{H}, \mathrm{H} 4$ '), 3.93 ("d," $J=2.1$, $12.6 \mathrm{~Hz}, 1 \mathrm{H}, \mathrm{H} 5 "), 4.24$ (dt, $J=8.4,12.1 \mathrm{~Hz}, 1 \mathrm{H}, \mathrm{H} 3$ '), 5.85 (d, $J=7.6 \mathrm{~Hz}, 1 \mathrm{H}, \mathrm{H} 5), 6.21$ ("t," $J=8.0 \mathrm{~Hz}, 1 \mathrm{H}, \mathrm{H} 1$ '), 7.75 (d, $J=7.6 \mathrm{~Hz}, 1 \mathrm{H}, \mathrm{H} 6) ;{ }^{19} \mathrm{~F} \mathrm{NMR}\left(\mathrm{CD}_{3} \mathrm{OD}\right) \delta-119.94$ (br. d, $J=240.6 \mathrm{~Hz}, 1 \mathrm{~F}),-118.83(\mathrm{dd}, J=10.3,238.3 \mathrm{~Hz}, 1 \mathrm{~F}) ; \mathrm{MS}\left(\mathrm{ESI}^{+}\right) m / z 421(100$, $\left.[\mathrm{M}+\mathrm{H}]^{+}\right)$.

\section{4-N-(3-Aminopropanyl)-2'-deoxy-2',2'-difluorocytidine (46). Method A.} Compound 45 (3.4 mg, $0.004 \mathrm{mmol})$ was dissolved in TFA $(1.0 \mathrm{~mL})$ and the mixture was stirred at ambient temperature overnight. After $15 \mathrm{~h}$, the reaction mixture was diluted with toluene, the volatiles were evaporated, and the residue co-evaporated with a fresh portion of toluene. The resulting residue was then column chromatographed $(10 \%$ $\mathrm{MeOH} / \mathrm{EtOAc})$ to give 46 (2.4 mg, 93\%) as a white solid: ${ }^{1} \mathrm{H}$ NMR $\left(\mathrm{CD}_{3} \mathrm{OD}\right) \delta 1.95$ (t, $J$ $\left.=6.8 \mathrm{~Hz}, 2 \mathrm{H}, \mathrm{CH}_{2}\right), 3.19\left(\mathrm{t}, J=6.8 \mathrm{~Hz}, 2 \mathrm{H}, \mathrm{CH}_{2}\right), 3.51-3.57\left(\mathrm{~m}, 2 \mathrm{H}, \mathrm{CH}_{2}\right), 3.81(\mathrm{dd}, J=$ 3.1, $12.0 \mathrm{~Hz}, 1 \mathrm{H}, \mathrm{H} 5 '), 3.91-3.99$ (m, 2H, H4', H5"), 4.28 (dt, $J=8.2,12.1 \mathrm{~Hz}, 1 \mathrm{H}, \mathrm{H} 3$ '), 5.92 (d, $J=7.5 \mathrm{~Hz}, 1 \mathrm{H}, \mathrm{H} 5), 6.25$ ("t," $J=8.1 \mathrm{~Hz}, 1 \mathrm{H}, \mathrm{H1}$ ), 7.88 (d, $J=7.1 \mathrm{~Hz}, 1 \mathrm{H}, \mathrm{H6}$ );

${ }^{19} \mathrm{~F} \mathrm{NMR}\left(\mathrm{CD}_{3} \mathrm{OD}\right) \delta-119.54$ (br. d, $\left.J=241.2 \mathrm{~Hz}, 1 \mathrm{~F}\right),-118.54(\mathrm{dd}, J=10.4,237.8 \mathrm{~Hz}$, 1F); $\mathrm{MS}\left(\mathrm{ESI}^{+}\right) \mathrm{m} / z 321\left(100,[\mathrm{M}+\mathrm{H}]^{+}\right)$. 
Method B. In a tightly sealed container, a solution of $\mathbf{3 2}(9.8 \mathrm{mg}, 0.024 \mathrm{mmol})$, commercially available $N$-Boc-1,3-propanediamine $(50 \mu \mathrm{L}, 50 \mathrm{mg}, 0.29 \mathrm{mmol})$ and TEA $\left(2 \mathrm{~mL}\right.$ ) in 1,4-dioxane was stirred at $75^{\circ} \mathrm{C}$. After $96 \mathrm{~h}$, the volatiles were evaporated, the resulting residue treated with TFA $(1.0 \mathrm{~mL})$ and the mixture stirred at ambient temperature overnight. After $15 \mathrm{~h}$, the reaction mixture was diluted with toluene, the volatiles were evaporated, and the residue co-evaporated with a fresh portion of toluene, and the resulting residue was then column chromatographed $(10 \% \mathrm{MeOH} / \mathrm{EtOAc})$ to give $46(7.8 \mathrm{mg}, 94 \%)$ with data as reported above.

4- $N$-(3- $N$ '-[SCN-Bn-NOTA] aminopropanyl)-2'-deoxy-2',2'-difluorocytidine (47). A mixture of SCN-Bn-NOTA (2.5 mg, $0.004 \mathrm{mmol})$ and 46 (2.4 mg, $0.007 \mathrm{mmol})$ in 0.1 $\mathrm{M} \mathrm{Na}_{2} \mathrm{CO}_{3}$ buffer ( $\mathrm{pH}$ 11) was stirred at ambient termperature for $60 \mathrm{~h}$. The reaction

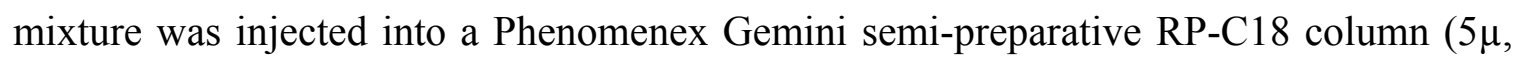
$25 \mathrm{~cm} \mathrm{X} 1 \mathrm{~cm}$ ) via $2 \mathrm{~mL}$ loop and eluted with $0 \% \rightarrow 100 \%$ ethanol gradient in $0.01 \%$ $\mathrm{TFA} / \mathrm{H}_{2} \mathrm{O}$ from 0 to $30 \mathrm{~min}$ at a flow rate $=5 \mathrm{~mL} / \mathrm{min}$. Analogue $47(2.0 \mathrm{mg}, 35 \%$ yield $)$ eluted with $\mathrm{rt}=14.1 \mathrm{~min}: \mathrm{MS}\left(\mathrm{ESI}^{+}\right) \mathrm{m} / z 771.3\left(100,[\mathrm{M}+\mathrm{H}]^{+}\right) ; \mathrm{HRMS}\left(\mathrm{ESI}^{+}\right) \mathrm{m} / z$ calcd for $\mathrm{C}_{32} \mathrm{H}_{45} \mathrm{~F}_{2} \mathrm{~N}_{8} \mathrm{O}_{10} \mathrm{~S}[\mathrm{M}+\mathrm{H}]^{+}$771.2942; found 771.2879.

\section{Gallium-4-N-(3- $N$ '-[SCN-Bn-NOTA] aminopropanyl)-2'-deoxy-2',2'-}

difluorocytidine (48). Gallium chloride $(5.1 \mathrm{mg}, 0.029 \mathrm{mmol})$ was added to a stirred solution of $47(1.0 \mathrm{mg}, 0.001 \mathrm{mmol})$ in $0.6 \mathrm{~N} \mathrm{NaCH}_{3} \mathrm{CO}_{2} / \mathrm{H}_{2} \mathrm{O}(1 \mathrm{~mL}, \mathrm{pH}=9.3)$ at ambient temperature. After $30 \mathrm{~min}$, the reaction mixture was diluted to a total volume of $1.5 \mathrm{~mL}$ with $\mathrm{H}_{2} \mathrm{O}$ and injected into a Phenomenex Gemini semi-preparative RP-C18 column $(5 \mu, 25 \mathrm{~cm} \times 1 \mathrm{~cm})$ via $2 \mathrm{~mL}$ loop and eluted with $0 \% \rightarrow 100 \%$ ethanol gradient in $0.01 \% \mathrm{TFA} / \mathrm{H}_{2} \mathrm{O}$ from 0 to $30 \mathrm{~min}$ at a flow rate $=5 \mathrm{~mL} / \mathrm{min}$. Analogue $48(0.5 \mathrm{mg}$, 
$46 \%$ yield) eluted with $t_{R}=12.4 \mathrm{~min}$. HRMS (ESI $\left.{ }^{+}\right) \mathrm{m} / z$ calcd for $\mathrm{C}_{32} \mathrm{H}_{42} \mathrm{~F}_{2} \mathrm{GaN}_{8} \mathrm{NaO}_{10} \mathrm{~S}$ $[\mathrm{M}+\mathrm{H}]^{+}$837.1963; found 837.1977.

Diallylacetic acid (50). A solution of $\mathrm{KOH}(2.6 \mathrm{~g}, 47 \mathrm{mmol})$ in $\mathrm{H}_{2} \mathrm{O}(7.5 \mathrm{~mL})$ was added to a stirred solution of commercial diethyl diallylmalonate $49(5.1 \mathrm{~g}, 21 \mathrm{mmol})$ in EtOH $(12.5 \mathrm{~mL})$ under Ar atmosphere and refluxed at $95{ }^{\circ} \mathrm{C}$. After $6 \mathrm{~h}$, volatiles were evaporated and the residue diluted with water, acidified with $\mathrm{HCl}(1 \mathrm{~N})$, and extracted with $\mathrm{Et}_{2} \mathrm{O}(3 \mathrm{x})$. The combined organic extract was dried over $\mathrm{Na}_{2} \mathrm{SO}_{4}$ and evaporated under reduced pressure to give a crude white solid (3.881 g, 100\%): ${ }^{1} \mathrm{H}$ NMR (400 MHz, $\left.\mathrm{CDCl}_{3}\right) \delta 2.71(\mathrm{~d}, J=7.4 \mathrm{~Hz}, 4 \mathrm{H}), 5.15-5.21(\mathrm{~m}, 4 \mathrm{H}), 5.65-5.76(\mathrm{~m}, 2 \mathrm{H})$. The crude mixture was then stirred and heated at $156^{\circ} \mathrm{C}$. After $30 \mathrm{~min}$ the temperature was lowered to $144{ }^{\circ} \mathrm{C}$. After $3 \mathrm{hrs}$ reaction mixture was column chromatographed $(20 \rightarrow 30 \%$ EtOAc/hexane) to give $\mathbf{5 0}^{177}$ (1.12 g, 38\%) as a colorless oil: ${ }^{1} \mathrm{H}$ NMR (400 MHz, $\left.\mathrm{CDCl}_{3}\right) \delta$ 2.26-2.44 (m, 4H), 2.53-2.60 (m, 1H), 5.05-5.12 (m, 4H), 5.72-5.82 (m, 2H).

4-Fluoro-2-(2-fluoropropyl)pentanoic acid (51). HF-pyridine (70\%, $2 \mathrm{~mL})$ was added to a stirred solution of $\mathbf{5 0}(0.26 \mathrm{~mL} 250 \mathrm{mg}, 1.8 \mathrm{mmol})$ in a PFA container at $0{ }^{\circ} \mathrm{C}$. After 1 hour, a fresh portion of HF-pyridine $(70 \%, 2 \mathrm{~mL})$ was added to the reaction mixture and stirring continued. After another $1 \mathrm{~h}$, the last portion of HF-pyridine ( $70 \%, 4$ $\mathrm{mL}$ ) was added and the reaction mixture continued stirring while gradually allowing vessel to reach ambient temperature. After $15 \mathrm{~h}$, the reaction mixture was diluted with ice- $\mathrm{H}_{2} \mathrm{O}$ and extracted with $\mathrm{CHCl}_{3}(3 \mathrm{x})$. The combined organic extract was washed with brine, dried over $\mathrm{Na}_{2} \mathrm{SO}_{4}$, concentrated under reduced pressure and the resulting residue was then column chromatographed $(10 \rightarrow 20 \% \mathrm{EtOAc} / \mathrm{Hex})$ to give $\mathbf{5 1}(1.270 \mathrm{~g}, 62 \%)$ : $\operatorname{MS}\left(\mathrm{ESI}^{+}\right) \mathrm{m} / z 209\left(100,[\mathrm{M}+\mathrm{H}]^{+}\right.$. 
Diethyl 2-(3-phenoxypropyl)-2-propylmalonate (53). LDA (2 M solution in $\mathrm{THF} /$ heptanes/ethylbenzene) was added to a stirred solution of diethyl propylmalonate (52, $2.26 \mathrm{~mL}, 12 \mathrm{mmol})$ in anhydrous $\mathrm{DMF}(12 \mathrm{~mL})$ at $0^{\circ} \mathrm{C}$. After 30 minutes 3phenoxypropyl bromide $(2.238 \mathrm{~mL}, 3.096 \mathrm{~g}, 14.4 \mathrm{mmol})$ was added dropwise. Resulting yellow, clear solution was stirred for $32 \mathrm{hrs}$ at ambient temperature. Reaction mixture was then diluted with $\mathrm{Et}_{2} \mathrm{O}$, treated with $\mathrm{NaHCO}_{3}$ and extracted in the organic phase. Combined extract was washed with brine, dried over $\mathrm{Na}_{2} \mathrm{SO}_{4}$, and concentrated to give crude 53 (1.70 g, 42\%): ${ }^{1} \mathrm{H}$ NMR $\left(400 \mathrm{MHz}, \mathrm{CDCl}_{3}\right) \delta 0.94(\mathrm{t}, J=7.3 \mathrm{~Hz}, 3 \mathrm{H}), 1.22-1.26$ $(\mathrm{m}, 8 \mathrm{H}), 1.64-1.72(\mathrm{~m}, 2 \mathrm{H}), 1.88-1.92(\mathrm{~m}, 2 \mathrm{H}), 2.04-2.09(\mathrm{~m}, 2 \mathrm{H}), 3.95(\mathrm{t}, J=6.3 \mathrm{~Hz})$, $4.18(\mathrm{q}, J=7.1 \mathrm{~Hz}, 4 \mathrm{H}), 6.87(\mathrm{~d}, J=8.7 \mathrm{~Hz}, 2 \mathrm{H}), 6.92(\mathrm{t}, J=7.3 \mathrm{~Hz}, 1 \mathrm{H}), 7.24-7.28(\mathrm{~m}$, 2H); GC-MS $m / z 336\left(\mathrm{M}^{+} ; t_{\mathrm{R}}=23.36 \mathrm{~min}\right)$.

5-Bromo-2-propylpentanoic acid (54). $\mathrm{HBr}(5 \mathrm{~mL}, 49 \%)$ was added to a stirred $\mathbf{5 3}$ (40 mg, $0.12 \mathrm{mmol}$ ) and refluxed at $140{ }^{\circ} \mathrm{C}$. After $3 \mathrm{hrs}$ the reaction mixture was diluted with $\mathrm{H}_{2} \mathrm{O}$ and extracted with EtOAc. The combined organic extract was then washed with brine, dried over $\mathrm{Na}_{2} \mathrm{SO}_{4}$, evaporated under reduced pressure and the resulting residue column chromatographed $\left(30 \rightarrow 40 \%\right.$ EtOAc/hexane) to give $54(8.7 \mathrm{mg}, 33 \%):{ }^{1} \mathrm{H}$ NMR $\left(400 \mathrm{MHz}, \mathrm{CDCl}_{3}\right) \delta 0.93\left(\mathrm{t}, J=7.2 \mathrm{~Hz}, 3 \mathrm{H}, \mathrm{CH}_{3}\right), 1.32-1.41\left(\mathrm{~m}, 2 \mathrm{H}, \mathrm{CH}_{2}\right), 1.44-$ $1.52(\mathrm{~m}, 1 \mathrm{H}, \mathrm{CH}), 1.61-1.80\left(\mathrm{~m}, 3 \mathrm{H}, \mathrm{CH}_{3}\right), 1.84-1.95\left(\mathrm{~m}, 2 \mathrm{H}, \mathrm{CH}_{2}\right), 2.37-2.44(\mathrm{~m}, 1 \mathrm{H}$, $\mathrm{CH}), 3.41$ (“dt”, $\left.J=1.2,6.7 \mathrm{~Hz}, 2 \mathrm{H}, \mathrm{CH}_{2}\right) ;{ }^{13} \mathrm{C} \mathrm{NMR}\left(400 \mathrm{MHz}, \mathrm{CDCl}_{3}\right) \delta 14.1,20.5$, 30.5, 30.6, 33.4, 34.4, 44.5, 181.7; GC-MS m/z 222/224 $\left(\left[{ }^{79} \mathrm{Br}\right] /\left[{ }^{81} \mathrm{Br}\right] \mathrm{M}^{+} ; t_{\mathrm{R}}=13.78\right.$ $\min )$.

5-Bromo-2-propylpentanoyl chloride (55). Compound 54 was dissolved in freshly distilled $\left.\mathrm{SOCl}_{2}(1 \mathrm{~mL}, 13.8 \mathrm{mmol})\right)$ was added to at ambient temperature and stirred. 
After 4 h, volatiles were evaporated to give $\mathbf{5 5}$ as a colorless oil: ${ }^{1} \mathrm{H}$ NMR $(400 \mathrm{MHz}$, $\left.\mathrm{CDCl}_{3}\right) \delta 0.95(\mathrm{t}, J=7.3 \mathrm{~Hz}, 3 \mathrm{H}), 1.35-1.44(\mathrm{~m}, 2 \mathrm{H}), 1.52-1.59(\mathrm{~m}, 3 \mathrm{H}), 1.73-1.83(\mathrm{~m}$, $2 \mathrm{H}), 1.84-1.96(\mathrm{~m}, 3 \mathrm{H}), 2.78-2.85(\mathrm{~m}, 1 \mathrm{H}), 3.39-3.44(\mathrm{~m}, 2 \mathrm{H}) ;{ }^{13} \mathrm{C}$ NMR $(400 \mathrm{MHz}$, $\left.\mathrm{CDCl}_{3}\right) \delta 14.0,20.2,29.9,30.5,32.8,34.2,56.3,100.1$.

10-Fluoroundecanoic Acid (57). HF-pyridine (70\%, $10 \mathrm{~mL}$ ) was added to a stirred solution of commercially available undecylenic acid $(\mathbf{5 6}, 2.03 \mathrm{~mL} 2.23 \mathrm{mg}, 10$ mmol) in a HDPE container at $0{ }^{\circ} \mathrm{C}$. After 1 hour, a fresh portion of HF-pyridine (70\%, 5 $\mathrm{mL}$ ) was added to the reaction mixture and stirring was continued for 1 hour. Reaction mixture was diluted with ice- $\mathrm{H}_{2} \mathrm{O}$ and extracted with chloroform (3x). The combined organic layer was washed with brine, dried with $\mathrm{Na}_{2} \mathrm{SO}_{4}$ and then column chromatographed $\left(20 \rightarrow 30 \%\right.$ EtOAc/hexane) to give $57^{167}(1.270 \mathrm{~g}, 62 \%):{ }^{1} \mathrm{H}$ NMR (400 MHz, $\left.\mathrm{CDCl}_{3}\right) \delta 1.27-1.67(\mathrm{~m}, 17 \mathrm{H}), 2.35$ (t, $\left.J=7.5 \mathrm{~Hz}, 2 \mathrm{H}\right), 4.65$ ('dm', $J=50.1$ $\mathrm{Hz}, \mathrm{CHF}, 1 \mathrm{H}) ;{ }^{13} \mathrm{C} \mathrm{NMR}\left(400 \mathrm{MHz}, \mathrm{CDCl}_{3}\right) \delta 21.1\left(\mathrm{~d}, J=22.8 \mathrm{~Hz}, \mathrm{CH}_{3}\right), 24.8,25.15$, 25.2, 29.2, 29.3, 29.4, 29.5, 34.0, 37.1 (d, $\left.J=20.7 \mathrm{~Hz}, \mathrm{CH}_{2} \mathrm{CHF}\right), 91.2$ (d, $J=164 \mathrm{~Hz}$, CHF), 179.1 (HOCO); ${ }^{19} \mathrm{~F}$ NMR (376 MHz, $\left.\mathrm{CDCl}_{3}\right) \delta-171.91--172.34$ (m, 1F).

Minor isomers $\mathbf{5 8}$ and $\mathbf{5 9}$ had the following distinguishable peaks: ${ }^{1} \mathrm{H}$ NMR (400 $\left.\mathrm{MHz}, \mathrm{CDCl}_{3}\right) \delta 4.40(\mathrm{~d}$ of $\mathrm{m}, J=50.7 \mathrm{~Hz}, \mathrm{CHF}, 1 \mathrm{H}) ;{ }^{19} \mathrm{~F} \mathrm{NMR}\left(376 \mathrm{MHz}, \mathrm{CDCl}_{3}\right) \delta-$ 181.07--181.45 (m, 20\% intensity of a peak) and -180.19-- 180.56 (m, 5\% intensity of a peak).

Methyl 11-Bromoundecanoate (61). Diazomethane [10 $\mathrm{mL}$ of ethereal solution generated from Diazald $(10 \mathrm{~g}, 46 \mathrm{mmol})$ ] was added to a stirred solution of commercially available 11-bromoundecanoic acid $(\mathbf{6 0}, 4.47 \mathrm{~g}, 17 \mathrm{mmol})$ in $\mathrm{Et}_{2} \mathrm{O}(5 \mathrm{~mL})$ at $0{ }^{\circ} \mathrm{C}$. After 30 minutes, volatiles were evaporated under reduced pressure to give $\mathbf{6 1}^{151}$ (4.70 g. 
$100 \%)$ as a solid: ${ }^{1} \mathrm{H}$ NMR $\left(\mathrm{CDCl}_{3}\right) \delta 1.29(\mathrm{~s}, 10 \mathrm{H}, 5 \mathrm{x} \mathrm{CH}), 1.42\left(\mathrm{~m}, 2 \mathrm{H}, \mathrm{CH}_{2}\right), 1.62$ (m, 2H, $\mathrm{CH}_{2}$ ), 1.85 (quint, $J=7.2 \mathrm{~Hz}, 2 \mathrm{H}, \mathrm{CH}_{2}$ ), 2.30 (t, $J=7.5 \mathrm{~Hz}, 2 \mathrm{H}, \mathrm{CH}_{2}$ ), 3.41 (t, $J$ $\left.=6.8 \mathrm{~Hz}, \mathrm{CH}_{2}\right)$, and $3.67\left(\mathrm{~s}, 3 \mathrm{H}, \mathrm{CH}_{3}\right)$; GC-MS $m / z 278 / 280\left(\left[{ }^{79} \mathrm{Br}\right] /\left[{ }^{81} \mathrm{Br}\right] \mathrm{M}^{+}, t_{\mathrm{R}}=17.92\right.$ $\min )$.

Methyl 11-Fluoroundecanoate (62). Neat TBAF· $3 \mathrm{H}_{2} \mathrm{O}(585 \mathrm{mg}, 2.28 \mathrm{mmol})$ was added to methyl 11-bromoundecanoate $61(200 \mathrm{mg}, 0.90 \mathrm{mmol})$ and stirred at $85{ }^{\circ} \mathrm{C}$. After 25 minutes, the reaction was quenched with water and extracted with pentane (3x). The combined organic layer was dried with $\mathrm{Na}_{2} \mathrm{SO}_{4}$, evaporated under reduced pressure and the resulting residue was column chromatographed $(0 \rightarrow 3 \%$ EtOAc/hexane) to give 62 $^{169}(65 \mathrm{mg}, 33 \%)$ as a viscous oil: ${ }^{1} \mathrm{H}$ NMR $\left(\mathrm{CDCl}_{3}\right) \delta 1.18-1.38\left(\mathrm{~m}, 12 \mathrm{H}, 6 \times \mathrm{CH}_{2}\right)$, 1.54-1.71 (m, 4H, $\left.2 \times \mathrm{CH}_{2}\right), 2.26\left(\mathrm{t}, J=7.5 \mathrm{~Hz}, 2 \mathrm{H}, \mathrm{CH}_{2}\right), 3.62\left(\mathrm{~s}, 3 \mathrm{H}, \mathrm{CH}_{3}\right), 4.39$ (dt, $J$ $\left.=47.4,6.2 \mathrm{~Hz}, \mathrm{CH}_{2}\right) ;{ }^{19} \mathrm{~F} \mathrm{NMR}\left(376 \mathrm{MHz}, \mathrm{CDCl}_{3}\right) \delta-217.99(\mathrm{tt}, J=24.0,47.3 \mathrm{~Hz}, 1 \mathrm{~F})$; GC-MS $m / z 218\left(\mathrm{M}^{+} ; t_{\mathrm{R}}=14.86 \mathrm{~min}\right)$.

Note: Compound 62 contained approximately $8 \%\left({ }^{1} \mathrm{H}\right.$ NMR, GC-MS) of the corresponding methyl 10-undecenoate as judged by the presence of the olefinic hydrogens at $\delta 4.95$ and $\delta 5.80$. GC-MS $m / z 198\left(\mathrm{M}^{+} ; t_{\mathrm{R}}=13.19 \mathrm{~min}\right)$.

11-Fluoroundecanoic Acid (63). $\mathrm{NaOH}(1 \mathrm{M}, 1.25 \mathrm{~mL})$ was added to a solution of 62 (65 mg, $0.30 \mathrm{mmol})$ in $\mathrm{MeOH}(1 \mathrm{~mL})$ and stirred at ambient temperature. After 90 minutes, the reaction mixture was diluted with water and was extracted with $\mathrm{Et}_{2} \mathrm{O}$ to remove any unreacted starting material. The aqueous layer was then acidified with $\mathrm{HCl}$ (3 $\mathrm{M})$ and extracted with fresh portions of $\mathrm{Et}_{2} \mathrm{O}(2 \mathrm{x})$. The combined fresh organic layer was then washed with brine, dried over $\mathrm{Na}_{2} \mathrm{SO}_{4}$ and evaporated under reduced pressure to give $\mathbf{6 3}^{178}(52 \mathrm{mg}, 85 \%)$ as a solid: ${ }^{1} \mathrm{H}$ NMR $\left(\mathrm{CDCl}_{3}\right) \delta 1.34\left(\mathrm{~m}, 12 \mathrm{H}, 6 \times \mathrm{CH}_{2}\right), 1.64-$ 
$1.79\left(\mathrm{~m}, 4 \mathrm{H}, 2 \times \mathrm{CH}_{2}\right), 2.40\left(\mathrm{t}, J=7.5 \mathrm{~Hz}, 2 \mathrm{H}, \mathrm{CH}_{2}\right), 4.48(\mathrm{dt}, J=47.3,6.2 \mathrm{~Hz}, 2 \mathrm{H}$, $\left.\mathrm{CH}_{2}\right) ;{ }^{13} \mathrm{C} \mathrm{NMR}\left(\mathrm{CDCl}_{3}\right) \delta 24.96,25.27,29.20,29.33,29.44,29.55,30.44,30.63,34.36$, $84.34(\mathrm{~d}, J=164.0 \mathrm{HZ}), 179.62 ;{ }^{19} \mathrm{~F} \mathrm{NMR}\left(\mathrm{CDCl}_{3}\right)-217.97(\mathrm{tt}, J=24.2,47.4 \mathrm{~Hz}) ; \mathrm{GC}-$ MS $m / z 204\left(\mathrm{M}^{+} ; t_{\mathrm{R}}=15.70 \mathrm{~min}\right)$; HRMS $(\mathrm{ESI}+) \mathrm{m} / z$ calcd for $\mathrm{C}_{11} \mathrm{H}_{22} \mathrm{FO}_{2}[\mathrm{M}+\mathrm{H}]^{+}$ 299.0849; found 299.0861.

Note: Compound 63 contained approximately $8 \%\left({ }^{1} \mathrm{H}\right.$ NMR) of the corresponding $10-$ undecelenic acid as judged by the presence of the olefinic hydrogens at $\delta 4.93$ and $\delta 5.81$. GC-MS m/z $198\left(\mathrm{M}^{+} ; t_{\mathrm{R}}=13.19 \mathrm{~min}\right)$.

11-Bromoundecanoyl chloride (64). Commercially available 11-bromoundecanoic acid 60 (1.03 g, $3.9 \mathrm{mmol})$ was dissolved in freshly distilled $\mathrm{SOCl}_{2}(1 \mathrm{~mL}, 13.8 \mathrm{mmol})$ and stirred overnight at ambient temperature. After $18 \mathrm{~h}$, excess $\mathrm{SOCl}_{2}$ was evaporated under reduced pressure to give $\mathbf{6 4}^{167}(1.09 \mathrm{~g}, 99 \%)$ as a clear oil of sufficient purity to be used in subsequent step: ${ }^{1} \mathrm{H}$ NMR $\left(\mathrm{CDCl}_{3}\right) \delta 1.30-1.48\left(\mathrm{~m}, 12 \mathrm{H}, 6 \times \mathrm{CH}_{2}\right), 1.73$ (quint, $J$ $\left.=7.3 \mathrm{~Hz}, 2 \mathrm{H}, \mathrm{CH}_{2}\right), 1.87\left(\mathrm{~m}, 2 \mathrm{H}, \mathrm{CH}_{2}\right), 2.90\left(\mathrm{t}, J=7.3 \mathrm{~Hz}, 2 \mathrm{H}, \mathrm{CH}_{2}\right), 3.43(\mathrm{t}, J=6.9 \mathrm{~Hz}$, $2 \mathrm{H}, \mathrm{CH}_{2}$.

11-Aminoundecan-1-ol (66). Lithium aluminum hydride (LAH, $1.6 \mathrm{~g}, 26.35 \mathrm{mmol}$ ) was added to a stirred solution of commercially available 11-aminoundecanoic acid $\mathbf{6 5}$ (6 g, $30 \mathrm{mmol})$ in THF $(60 \mathrm{~mL})$ at $-20{ }^{\circ} \mathrm{C}$ under Argon. After stirring for $30 \mathrm{~min}$, the reaction mixture was allowed to warm up to ambient temperature and gradually heated to $70{ }^{\circ} \mathrm{C}$ (oil-bath) while stirring continued. After $24 \mathrm{~h}$, a second portion of LAH $(1.6 \mathrm{~g})$ was added to the reaction mixture under Argon and the reaction kept stirring at $70{ }^{\circ} \mathrm{C}$. After another $24 \mathrm{~h}$, the reaction mixture was chilled to $0{ }^{\circ} \mathrm{C}$ (ice-bath) and then quenched by careful addition of $10 \% \mathrm{NaOH}(20 \mathrm{~mL})$ and subsequent addition of $\mathrm{H}_{2} \mathrm{O}(30 \mathrm{~mL})$. A 
pasty white precipitate formed and the mixture was stirred overnight at room temperature. The resulting solution was decanted and kept separate from the precipitate. The precipitate was washed with fresh portions of THF $(30 \mathrm{~mL})$, shaken rigorously and the resulting solution also decanted. The combined organic layer was then dried over $\mathrm{MgSO}_{4}$ and evaporated under reduced pressure to give $66^{170}(4.3 \mathrm{~g}, 75 \%)$ as a white solid of sufficient purity to be used in next step: ${ }^{1} \mathrm{H}$ NMR $\left(\mathrm{CDCl}_{3}\right) \delta 1.28$ (br. s, $\left.14 \mathrm{H}, 7 \times \mathrm{CH}_{2}\right)$, 1.39-1.44 (m, 2H, $\mathrm{CH}_{2}$ ), 1.56 (quin, $J=7.0 \mathrm{~Hz}, 2 \mathrm{H}, \mathrm{CH}_{2}$ ), 2.67 (t, $J=7.0 \mathrm{~Hz}, 2 \mathrm{H}, \mathrm{CH}_{2}$ ), $3.63\left(\mathrm{t}, J=6.6 \mathrm{~Hz}, 2 \mathrm{H}, \mathrm{CH}_{2}\right)$.

tert-Butyl $N$-(11-Hydroxyundecyl) carbamate (67). di-tert-Butyl-dicarbonate (1.3 g, $5.96 \mathrm{mmol})$ was added to a solution of $66(1 \mathrm{~g}, 3.48 \mathrm{mmol})$ in $\mathrm{MeOH}(30 \mathrm{~mL})$ and stirred at ambient temperature. After $1 \mathrm{~h}$, the volatiles were evaporated under reduced pressure and the resulting residue was then column chromatographed $\left(\mathrm{CHCl}_{3}\right)$ to give $\mathbf{6 7}^{170}(1.5 \mathrm{~g}, 98 \%)$ as a white solid. ${ }^{1} \mathrm{H}$ NMR $\left(\mathrm{CDCl}_{3}\right): \delta 1.26$ (br. s, $\left.14 \mathrm{H}, 7 \times \mathrm{CH}_{2}\right), 1.43$ (br. s, $\left.11 \mathrm{H}, \mathrm{C}\left(\mathrm{CH}_{3}\right)_{3}+\mathrm{CH}_{2}\right), 1.55$ (quint, $\left.J=7.0 \mathrm{~Hz}, 2 \mathrm{H}, \mathrm{CH}_{2}\right), 3.09$ (q, $J=6.4 \mathrm{~Hz}, 2 \mathrm{H}$, $\left.\mathrm{CH}_{2}\right), 3.62\left(\mathrm{t}, J=6.4 \mathrm{~Hz}, 2 \mathrm{H}, \mathrm{CH}_{2}\right)$.

tert-Butyl N-(11-Benzyloxyundecyl) carbamate (69). Step a. Methanesulfonyl chloride $(370 \mu \mathrm{L}, 545 \mathrm{mg}, 4.8 \mathrm{mmol})$ was added to a stirred solution of 67 (1.1 g, 4.0 mmol) and triethylamine $(830 \mu \mathrm{L}, 602 \mathrm{mg}, 5.9 \mathrm{mmol})$ in $\mathrm{CH}_{2} \mathrm{Cl}_{2}(20 \mathrm{~mL})$ at $0{ }^{\circ} \mathrm{C}$ under Argon. After stirring for $5 \mathrm{~min}$, the resulting mixture was allowed to warm up to ambient temperature and kept stirring. After $1 \mathrm{~h}$, the reaction mixture was diluted with $\mathrm{CH}_{2} \mathrm{Cl}_{2}(30$ $\mathrm{mL})$ and partitioned with $\mathrm{H}_{2} \mathrm{O}(30 \mathrm{~mL})$ and the aqueous layer extracted with fresh portions of $\mathrm{CH}_{2} \mathrm{Cl}_{2}(2 \times 30 \mathrm{~mL})$. The combined organic layer was then washed with brine $(30 \mathrm{~mL})$, dried over $\mathrm{Na}_{2} \mathrm{SO}_{4}$ and evaporated under reduced pressure to give the tert-butyl 
$N$-(11-methanesulfonyloxyundecyl) carbamate $68(1.41 \mathrm{~g}, 98 \%)$ as a crude yellow solid of sufficient purity ( $\geq 95 \%)$ for the subsequent step: ${ }^{1} \mathrm{H}$ NMR $\left(\mathrm{CDCl}_{3}\right) \delta 1.27$ (br. s, $14 \mathrm{H}$, 7 x CH $\left.\mathrm{CH}_{2}\right), 1.35-1.49\left(\mathrm{~m}, 11 \mathrm{H}, \mathrm{C}\left(\mathrm{CH}_{3}\right)_{3}, \mathrm{CH}_{2}\right), 1.75$ ("quin," $\left.J=8.0 \mathrm{~Hz}, 2 \mathrm{H}, \mathrm{CH}_{2}\right), 3.00$ (s, $\left.3 \mathrm{H}, \mathrm{CH}_{3}\right), 3.10$ ("q," $\left.J=6.9 \mathrm{~Hz}, 2 \mathrm{H}, \mathrm{CH}_{2}\right), 4.22\left(\mathrm{t}, J=6.6 \mathrm{~Hz}, 2 \mathrm{H}, \mathrm{CH}_{2}\right.$ ). Step b. Sodium benzoxide [prepared by addition of $\mathrm{NaH}(228 \mathrm{mg}, 4.76 \mathrm{mmol} ; 60 \%$ in dispersion paraffin) to a stirred solution of benzyl alcohol (591 $\mu \mathrm{L}, 657 \mathrm{mg}, 4.76 \mathrm{mmol})$ in DMF (10 $\mathrm{mL}$ ) at $0{ }^{\circ} \mathrm{C}$ (ice-bath) placed in a flame-dried flask under argon atmosphere (stirred 30 min)] was added dropwise to a solution of the crude $\mathbf{6 8}$ from Step $a$ in DMF $(10 \mathrm{~mL})$ and stirred at ambient temperature. After $22 \mathrm{~h}$, the reaction mixture was poured into a separatory funnel containing $\mathrm{H}_{2} \mathrm{O}$ and extracted with EtOAc $(3 \times 30 \mathrm{~mL})$. The combined extracts was dried over $\mathrm{Na}_{2} \mathrm{SO}_{4}$ and evaporated under reduced pressure to give 69 (1.43 g, $95 \%$ ) as a clear oil of sufficient purity ( $\geq 95 \%$ ) for the subsequent step: ${ }^{1} \mathrm{H}$ NMR $\left(\mathrm{CDCl}_{3}\right) \delta 1.25$ (br. s, $\left.14 \mathrm{H}, 7 \times \mathrm{CH}_{2}\right), 1.32-1.38\left(\mathrm{~m}, 2 \mathrm{H}, \mathrm{CH}_{2}\right), 1.44\left(\mathrm{~s}, 9 \mathrm{H}, \mathrm{C}\left(\mathrm{CH}_{3}\right)_{3}\right)$, 1.57-1.64 (m, 2H, $\left.\mathrm{CH}_{2}\right), 3.09$ (q, $\left.J=6.3 \mathrm{~Hz}, 2 \mathrm{H}, \mathrm{CH}_{2}\right), 3.46\left(\mathrm{t}, J=13.3 \mathrm{~Hz}, 2 \mathrm{H}, \mathrm{CH}_{2}\right)$, $4.50\left(\mathrm{~s}, 2 \mathrm{H}, \mathrm{CH}_{2}\right), 7.27-7.35(\mathrm{~m}, 5 \mathrm{H}, \mathrm{Ar}) . \mathrm{HRMS}\left(\mathrm{ESI}^{+}\right) \mathrm{m} / \mathrm{z}$ calcd for $\mathrm{C}_{23} \mathrm{H}_{40} \mathrm{NO}_{3}$ $[\mathrm{M}+\mathrm{H}]^{+}$378.3003; found 378.3010.

11-Benzyloxyundecan-1-amine (70). TFA $(10 \mathrm{~mL})$ was added to a stirred solution of the crude $69(1.40 \mathrm{~g}, 3.95 \mathrm{mmol})$ in $\mathrm{CH}_{2} \mathrm{Cl}_{2}(30 \mathrm{~mL})$ at $0{ }^{\circ} \mathrm{C}$. After $5 \mathrm{~min}$, the mixture was allowed to warm up to ambient temperature and kept stirring for $1 \mathrm{~h}$. Volatiles were evaporated under reduced pressure and the resulting residue was column chromatographed (2.5\% MeOH/EtOAc) to give 70 (953 mg, 92\%) as a colorless oil: ${ }^{1} \mathrm{H}$ $\operatorname{NMR}\left(\mathrm{CDCl}_{3}\right) \delta 1.18$ (br. s, 14H, 7 x CH $\left.\mathrm{CH}_{2}\right), 1.50-1.57(\mathrm{~m}, 4 \mathrm{H}), 2.80(\mathrm{t}, J=7.4 \mathrm{~Hz}, 2 \mathrm{H}$, $\left.\mathrm{CH}_{2}\right), 3.39\left(\mathrm{t}, J=6.7 \mathrm{~Hz}, 2 \mathrm{H}, \mathrm{CH}_{2}\right), 4.42\left(\mathrm{~s}, 2 \mathrm{H}, \mathrm{CH}_{2}\right), 7.26-7.27$ (m, 5H, Ar); ${ }^{13} \mathrm{C} \mathrm{NMR}$ 
$\left(\mathrm{CDCl}_{3}\right) \delta 26.31,26.47,27.66,29.10,29.44,29.56,29.58,29.65,29.89,40.05,70.68$,

72.98, 127.59, 127.75, 128.47, 138.85; MS $\left(\mathrm{ESI}^{+}\right) \mathrm{m} / z 278\left(100,[\mathrm{M}+\mathrm{H}]^{+}\right.$. HRMS $\left(\mathrm{ESI}^{+}\right)$ $m / z$ calcd for $\mathrm{C}_{18} \mathrm{H}_{32} \mathrm{NO}[\mathrm{M}+\mathrm{H}]^{+} 278.2478$; found 278.2499.

\subsection{Biological screening and evaluation}

\subsubsection{Preliminary cytostatic evaluation}

\subsubsection{Cell line and culture conditions}

MCF-7 (human breast adenocarcinoma) cells were cultured in DMEM/F-12 media supplemented with $10 \%$ heat-inactivated fetal bovine serum, antibiotics $(10,000$ units $/ \mathrm{mL}$ Penicillin, 10,000 $\mu \mathrm{g} / \mathrm{mL}$ Streptomycin) and HEPES Buffer (1M solution). Cells were maintained in a humidified atmosphere at $37^{\circ} \mathrm{C}$ with $5 \% \mathrm{CO}_{2}$ and sub-cultured twice a week and harvested by trypsinization during the exponential growth phase. Analogues to be tested were solubilized in EtOH, 1000-fold more concentrated than the maximum desired test concentration. At the time of compound addition, the analogue concentrate was diluted in full culture medium to 2-fold more concentrated than the maximum desired test concentration. From this working solution, additional test concentrations were prepared (10X serial dilutions).

\subsubsection{Cytostatic activity by sulphorhodamine B (SRB) staining}

Cells were plated in 96-well flat-bottom microtiter plates with a seeding density of 5 x $10^{3} /$ well in $100 \mu \mathrm{L}$ full culture medium. Microtiter plates were then pre-incubated for $24 \mathrm{~h}$ ensuring cell attachment. After $24 \mathrm{~h}, 100 \mu \mathrm{L}$ aliquots of the selected analogues (test concentrations $25 \mu \mathrm{M}$ to $2.5 \mathrm{nM}$ ) were added in the appropriate wells. Microtiter plates were then incubated in a humidified atmostphere at $37^{\circ} \mathrm{C}$ with $5 \% \mathrm{CO}_{2}$ for $72 \mathrm{~h}$. Cells were fixed by treatment with $50 \mu \mathrm{L}$ of $50 \%$ trichloroacetic acid (TCA), gently added to 
the wells, followed by incubation of microtiter plates at $4^{\circ} \mathrm{C}$. After $1 \mathrm{~h}, \mathrm{TCA}$ was removed flicking plates and washing four times with tap water. Cells were then treated with $100 \mu \mathrm{L}$ of $0.4 \% \mathrm{SRB}$ solution and allowed to stain for $15 \mathrm{~min}$ at ambient temperature. Excess unbound dye was removed by flicking and quickly washing with $1 \%$ acetic acid $(4 \times 200 \mu \mathrm{L})$. Plates were air dried overnight and bound dye was solubilized via treatment with $200 \mu \mathrm{L}$ of $10 \mathrm{mM}$ Tris base. After $30 \mathrm{~min}$, absorbance was measured using microplate reader at a wavelength of $560 \mathrm{~nm}$.

\subsubsection{Quantification of cell proliferation by measurement of 5-Bromo- deoxyuridine (BrdU) incorporation}

Cells were plated in 96-well flat-bottom microtiter plates with a seeding density of 5 x $10^{3} /$ well in $100 \mu \mathrm{L}$ full culture medium. Microtiter plates were then pre-incubated for $24 \mathrm{~h}$ ensuring cell attachment. After $24 \mathrm{~h}$, cells were exposed to $100 \mu \mathrm{L}$ aliquots of the selected analogues resulting in $25 \mu \mathrm{M}$ and $2.5 \mu \mathrm{M}$ testing concentrations. Microtiter plates were then incubated in a humidified atmostphere at $37^{\circ} \mathrm{C}$ with $5 \% \mathrm{CO}_{2}$ for either 24 h, 48 h, 72 h or 96 h. A commercially available kit (Cell Proliferation ELISA BrdU, colorimetric, Roche Diagnostics, Mannheim, Germany) was then used according to manufacturer's instructions. Shortly, $20 \mu \mathrm{L} /$ well BrdU labeling solution (final concentration $10 \mu \mathrm{M}$ ) was added and the cells incubated for two hours at $37^{\circ} \mathrm{C}$. After incubation, labeling solution was removed by flicking. The cells were then fixed with 200 $\mu \mathrm{L} /$ well FixDenat solution and incubated at ambient temperature. After $30 \mathrm{~min}$, FixDenat solution was removed by flicking followed by treatment of the cells with $100 \mu \mathrm{L} /$ well anti-BrdU-POD working solution and incubation at ambient temperature. After 90 min, antibody conjugate was removed by flicking and the cells washed three times with $1 \mathrm{X}$ 
DPBS. After removal of washing solution by flicking, $100 \mu \mathrm{L} /$ well of substrate solution was added and the cells were incubated at ambient temperature for a period of $30 \mathrm{~min}$. Absorbance was measured using microplate reader at a wavelength of $370 \mathrm{~nm}$.

\subsubsection{Cell cycle analysis by flow cytometry using propidium iodide staining.}

Cells were plated into 6-well flat-bottom microtiter plates with a seeding density of 1 x $10^{5}$ cells $/$ well in $2 \mathrm{~mL}$ culture medium containing $0.5 \%$ FBS. Microtiter plates were pre-incubated in a humidified atmosphere at $37^{\circ} \mathrm{C}$ with $5 \% \mathrm{CO}_{2}$ for $24 \mathrm{~h}$ ensuring cell attachment. After $24 \mathrm{~h}$, existing media was removed and to the appropriate wells were exposed to $2 \mathrm{~mL}$ aliquots of the selected analogues resulting in $25 \mu \mathrm{M}$ and $2.5 \mu \mathrm{M}$ testing concentrations. Microtiter plates were then incubated in a humidified atmostphere at $37^{\circ} \mathrm{C}$ with $5 \% \mathrm{CO}_{2}$ for either $24 \mathrm{~h}$ or $48 \mathrm{~h}$. A commercially available kit (Cell Cycle Phase Determination Kit, Cayman Chemical, Michigan, USA) was then used according to manufacturer's instructions. Shortly, Cells were then harvested by trypsinization and suspended in wash buffer. Cells were then pelleted by centrifugation and washed twice using assay Buffer. The cell pellet was then resuspended at $1 \times 10^{6}$ cells $/ \mathrm{mL}$ in Assay Buffer and treated with $1 \mathrm{~mL}$ Assay Fixative and incubated for 2 hrs. Fixed cells were then centrifuged at $500 \mathrm{xg}$ for five minutes. Assay Fixative was decanted thoroughly and the cell pellet suspended in $500 \mu \mathrm{L}$ Staining Solution $(20 \mu \mathrm{L} / \mathrm{mL}$ RNase and $20 \mu \mathrm{g} / \mathrm{mL}$ in Assay Buffer) and incubated at ambient temperature, in the dark for $30 \mathrm{~min}$. Measurements were then performed on a flow cytometer (Accuri C6, BD Accuri Cytometers, Michigan, USA) with a $488 \mathrm{~nm}$ excitation laser and analyzed using the accompanying BD CFlow Plus software. 


\subsubsection{Cytostatic evaluation in Panc-1 cells.}

The Panc-1 cells were cultured in DMEM medium supplemented with $10 \%$ fetal bovine serum and antibiotics (Penicillin and streptomycin) with 5\% $\mathrm{CO}_{2}$ incubator maintained at $37{ }^{\circ} \mathrm{C}$. Cells were harvested and plated at $1.0 \times 10^{4}$ cells/well in 96-well microtiter plates. After cell attachment was assured, cells in microtiter plates were treated with increasing concentrations of gemcitabine analogs $(0-200 \mu \mathrm{g} / \mathrm{ml})$ and incubated in the $\mathrm{CO}_{2}$ incubator at $37{ }^{\circ} \mathrm{C}$ for $48 \mathrm{~h}$. MTT assay was performed using the Cell Proliferation kit I (MTT) from Roche Biochemicals, IN and the plates were read in a Bio-Rad Benchmark multiwell plate reader at $570 \mathrm{~nm}$ wavelength with a reference wavelength of $655 \mathrm{~nm}$. For the assay, healthy viable cells produce blue crystals and non-viable cells do not produce any color. The absorbance estimates were used to calculate the percentage of viable cells which were plotted against drug concentrations and $\mathrm{IC}_{50}, \mathrm{IC}_{75}$ and $\mathrm{IC}_{90}$ values were derived from the graphs.

\subsubsection{In Vitro evaluation in L1210, CEM/0, CEM/dCK-, HeLa and MCF-7 murine and human tumor cell lines. ${ }^{179}$}

\subsubsection{Tumor cell and enzyme sources.}

The murine (leukemia L1210, human lymphocyte CEM) and human (cervix carcinoma HeLa) cell lines were purchased from ATCC, Rockville, MD. The human breast carcinoma MCF-7 cells were obtained as a gift to J. Balzarini from G. Peters (Amsterdam, The Netherlands). Based on the presence of arabinocytidine, the dCKdeficient CEM cell line was obtained upon selection of cells found to be deficient in cytosolic dCK activity. 


\subsubsection{Cytostatic activity assays.}

The analogues were added to murine leukemia L1210, human T-lymphocyte CEM, human cervix carcinoma HeLa and human breast carcinoma MCF-7 cell cultures in 96well microtiter plates at varying test concentrations. After two (L1210) or three (CEM) or four (HeLa, MCF-7) days incubation at $37^{\circ} \mathrm{C}$, the number of viable cells was determined by a Coulter counter. The $\mathrm{IC}_{50}$ values were determined as the analogues concentration required to inhibit cell proliferation by $50 \%$.

\subsubsection{Deoxycytidine kinase and thymidine Kinase-2 activity assays.}

The activity of recombinant mitochondrial thymidine kinase (TK-2) and cytosolic 2'deoxycytidine kinase $(\mathrm{dCK})$ were evaluated in the presesnce or absence of the analogues with assays conducted in $50 \mu \mathrm{L}$ reaction mixtures containing $50 \mathrm{mM}$ Tris $/ \mathrm{HCl}(\mathrm{pH} 8.0)$, $2.5 \mathrm{mM} \mathrm{MgCl} 2,10 \mathrm{mM}$ dithiothreitol, $0.5 \mathrm{mM}$ CHAPS, $3 \mathrm{mg} / \mathrm{mL}$ bovine serum albumin, $2.5 \mathrm{mM}$ ATP, $1 \mu \mathrm{M}\left[5{ }^{3} \mathrm{H}\right] \mathrm{dCyd}$ or $\left[\mathrm{CH}_{3}{ }^{3} \mathrm{H}\right] \mathrm{dThd}$ and enzyme. The samples were incubated at $37^{\circ} \mathrm{C}$ for 30 min with varying concentrations (5-fold dilutions) of the tested analogues. Aliquots $(45 \mu \mathrm{L})$ of the reaction mixtures were spotted on Whatman DE-81 filter paper disks, the filters were each washed three times, (1) for 5 min each in $1 \mathrm{mM}$ ammonium formate, (2) once for $1 \mathrm{~min}$ in water and (3) once for $5 \mathrm{~min}$ in ethanol. Scintillation counting was then used to determine the amount of radioactivity retained on the filter discs.

The selected analogues were exposed to TK-2 or dCK enzyme reactions mixtures at $100 \mu \mathrm{M}$ test concentrations. Substrate activity against TK-2 and dCK was evaluated by HPLC on an anion exchange Partisil Sax column, measuring conversion of the analogues to their 5'-monophosphate forms. 


\subsubsection{Human Serum and Murine Liver Extract Stability Assays.}

The selected analogues were exposed to $50 \%$ human serum or murine liver extract in PBS at $100 \mu \mathrm{M}$ test concentrations and incubated at varying time points $(0,60,240 \mathrm{~min}$ for human serum and $0,30,120 \mathrm{~min}$ for murine liver extract) at $37^{\circ} \mathrm{C}$. At each respective time point, an aliquot was then taken and evaluated by HPLC on a reverse phase RP-18 column with a $\mathrm{CH}_{3} \mathrm{CN} / \mathrm{H}_{2} \mathrm{O}$ mobile phase. Elution times were $13.2 \mathrm{~min}$ and $16.4 \mathrm{~min}$ for $\mathrm{dFdU}$ and gemcitabine, respectively, and $22.8 \mathrm{~min}$ and $22.7 \mathrm{~min}$ for the 4-Nalkanoylgemcitabine $\mathbf{2 1}$ and the 4- $N$-alkylgemcitabine 31, respectively. 


\section{CONCLUSION}

In this dissertation, I have reported the synthesis of a library of gemcitabine analogues with chemotherapeutic properties which feature 4- $\mathrm{N}$-alkanoyl and 4- $\mathrm{N}$-alkyl modifications with additional functional groups on the alkyl chain. These varying terminal modifications were designed to enable the incorporation of either ${ }^{18} \mathrm{~F}$ or ${ }^{68} \mathrm{Ga}$ radionuclides, adding a new depth and utility to these novel gemcitabine prodrugs as PET radiotracers.

In general, the synthesis of non-radioactive $4-N$-alkanoylgemcitabines was achieved by coupling of gemcitabine (1) with the various carboxylic acids (C9-C13) using peptide coupling conditions (HOBt/NMM/EDCI). This method was versatile in that it allowed introduction of aliphatic chains featuring different terminal functional groups (olefin, halo, alkyl ether or hydroxyl). Preparation of 4- $\mathrm{N}$-alkanoylgemcitabines with more labile terminal functionalities present on the aliphatic chain (such as bromo- or triflate- groups) required alternative condensation of $3^{\prime}, 5^{\prime}$-di- $O$-Boc-gemcitabine (16) with the corresponding acyl halides. The synthesis of the $4-\mathrm{N}$-alkylgemcitabines was achieved by displacement of the $p$-toluenesulfonamido group in the 4- $N$-tosylgemcitabine(s) with the corresponding alkyl amines having different terminal functionalities (hydroxyl, olefin and benzyloxy).

The 4- $\mathrm{N}$-alkanoyl and 4- $\mathrm{N}$-alkyl gemcitabine analogues featuring a terminal olefin on the aliphatic chain were efficiently fluorinated with HF/pyridine (Olah's reagent) to give the desired 4- $N$-fluoroalkanoyl and 4- $N$-fluoroalkyl derivatives as regioisomeric mixtures. This demonstrated the application of the olefinic gemcitabine analogues as convenient precursors for the fluorination with $\left[{ }^{18} \mathrm{~F}\right]-\mathrm{HF} / \mathrm{pyr}$ reagent. Direct fluorination 
of the 3',5'-di-O-Boc-protected 4- $N$-(11-hydroxyundecanoyl)gemcitabine with diethylaminosulfur trifluoride via $\mathrm{S}_{\mathrm{N}} 2$ type reaction gave the desired 4- $\mathrm{N}-(11-$ fluoroundecanoyl)gemcitabine, demonstrating again the synthetic versatility of the 4- $\mathrm{N}$ alkanoyl analogues. Since it was concluded that radiosynthetic protocols using KF and Kryptofix 222 typically require conditions in which the $4-\mathrm{N}$-amide linkage is cleaved, the 4- $\mathrm{N}$-alkylgemcitabine bearing a terminal hydroxyl group was prepared. This 4- $\mathrm{N}$ hydroxyalkyl gemcitabine analogue was efficiently fluorinated employing the common radiosynthetic protocols (KF/Kryptofix 222) via the mesylate intermediate. The developed fluorination protocol was then applied for the synthesis of the $\left[{ }^{18} \mathrm{~F}\right]-4-N-(11-$ fluroundecanyl)gemcitabine radioligand. The preliminary in vivo PET studies demonstrated $\mathrm{dCK}$ specific accumulation in the spleen tissues as well as dCK-nonspecific accumulation in CEM leukemia tumors.

The coupling of the tetraazacyclododecane NODAGA to gemcitabine afforded the NODAGA-4- $N$-alkanoylgemcitabine conjugate. Condensation of the tetraazacyclododecane SCN-Bn-NOTA with the " 2 nd generation" 4- $N-(3-$ aminopropyl)gemcitabine gave the NOTA-4- $N$-alkylgemcitabine conjugate. Labeling of the NOTA-4- $N$-alkylgemcitabine conjugate with $\left[{ }^{68} \mathrm{Ga}\right]{ }^{+3}$ afforded the desired $\left[{ }^{68} \mathrm{Ga}\right]-$ gallium-4- $N$-[3-(SCN-Bn-NOTA)-propanyl]gemcitabine radioligand with high labeling efficiency; substantiated by phosphor screen image amplification.

Evaluation on a panel of murine and human tumor cell lines revealed potent cytostatic activities for the 4- $\mathrm{N}$-alkanoylgemcitabines, with $\mathrm{IC}_{50}$ values in the $\mathrm{nM}$ range across most cell types, comparable to the parent gemcitabine. The cytostatic activities for the $4-\mathrm{N}$ alkanoylgemcitabines seemed to be independent of chain length and varied only slightly 
for the different functional groups. The 4- $\mathrm{N}$-alkylgemctiabines displayed less potent cytostatic activities with $\mathrm{IC}_{50}$ values in the low to modest $\mu \mathrm{M}$ range. Interestingly, the cytostatic activities for the 4- $\mathrm{N}$-valprolylgemcitabines were more comparable to the $4-\mathrm{N}$ alkylgemctiabines. A drastic decline in cytostatic activity for the 4-Nalkanoylgemcitabines and a lesser reduction observed for the 4- $\mathrm{N}$-alkylgemcitabines in the CEM/dCK- cell line validated the role deoxycytidine kinase plays in the metabolism of the analogues. When evaluated as substrates for deoxycytidine kinase and cytidine deaminase, none of the 4- $\mathrm{N}$-alkanoyl or the 4- $\mathrm{N}$-alkyl gemcitabine derivatives were found to be efficient substrates for the enzymes. Additionally, incubation of the 4- $\mathrm{N}$-modified gemcitabine analogues in human serum and murine liver extracts demonstrated the susceptibility of the 4- $\mathrm{N}$-alkanoylgemcitabines to undergo cleavage and eventual conversion to gemcitabine. Taken together with the marked loss of activity in the deoxycytidine kinase deficient cell line, it is likely that the 4- $\mathrm{N}$-alkanoylgemcitabines need to be converted to gemcitabine before interacting with deoxycytidine kinase or exhibiting their significant cytostatic activity. The 4- $\mathrm{N}$-alkylgemcitabines on the other hand were resistant to cleavage and appear to attain their modest activity via an alternative dCK-independent pathway or without a "measurable" conversion to gemcitabine. Quantification of cell proliferation and cell cycle analysis indicated inhibition of DNA synthesis and anti-proliferative activity as a mechanism of action for all 4-N-alkanoyl and 4- $N$-alkyl gemcitabine analogues. Cytostatic activity evaluated in Panc-1 cells was the first known example of a 4-N-alkyl gemcitabine derivative having comparable activity to a 4- $\mathrm{N}$-alkanoyl gemcitabine derivative. Additionally, the 4-N- 
alkylgemcitabines demonstrated the capacity to overcome the gemcitabine's inability to achieve $\mathrm{IC}_{75}$ and $\mathrm{IC}_{90}$ concentrations in Panc-1 cells.

In this dissertation, I have demonstrated that the developed 4- $N$-alkanoyl and 4- $\mathrm{N}$ alkyl gemcitabine analogues display cytostatic activity dependent on cancer cell type and possess potentially important therapeutic significance. The methodologies established herein not only set the precedence but might contribute towards developing the gemcitabine-based prodrugs as potential PET-based radiotracers.

Our preliminary PET-imaging results with the $\left[{ }^{18} \mathrm{~F}\right]$-modified $4-N-$ fluoroalkylgemcitabine indicated that the $\left[{ }^{18} \mathrm{~F}\right]$-radioligand underwent in vivo defluorination, as apparent by the accumulation of ${ }^{18} \mathrm{~F}$ - signal in the bones. The preparation and testing of a 4- $\mathrm{N}$-alkylgemcitabine derivative lacking hydrogens at the $\beta$ carbon to the fluorine atom is proposed as a possible means for overcoming the observed defluorination. 


\section{REFERENCES}

1. Siegel, R.; Naishadham, D.; Jemal, A. Cancer statistics for Hispanics/Latinos, 2012. CA Cancer J. Clin. 2012, 62, 283-298.

2. Hamacher, K.; Coenen, H. H.; Stocklin, G. Efficient Stereospecific Synthesis of No-Carrier-Added 2-[F-18]-Fluoro-2-Deoxy-D-Glucose Using Aminopolyether Supported Nucleophilic-Substitution. J. Nucl. Med. 1986, 27, 235-238.

3. Hanahan, D.; Weinberg, R. A. The hallmarks of cancer. Cell 2000, 100, 57-70.

4. Egeblad, L.; Welin, M.; Flodin, S.; Gräslund, S.; Wang, L.; Balzarini, J.; Eriksson, S.; Nordlund, P. Pan-Pathway Based Interaction Profiling of FDAApproved Nucleoside and Nucleobase Analogs with Enzymes of the Human Nucleotide Metabolism. Plos One 2012, 7, e37724.

5. Parker, W. B. Enzymology of purine and pyrimidine antimetabolites used in the treatment of cancer. Chem. Rev. 2009, 109, 2880-2893.

6. Galmarini, C. M.; Mackey, J. R.; Dumontet, C. Nucleoside analogues: mechanisms of drug resistance and reversal strategies. Leukemia 2001, 15, 875890 .

7. Singh, Y.; Palombo, M.; Sinko, P. J. Recent trends in targeted anticancer prodrug and conjugate design. Curr. Med. Chem. 2008, 15, 1802-1826.

8. Pankiewicz, K. W. Fluorinated nucleosides. Carbohydr. Res. 2000, 327, 87-105.

9. McAtee, J. J.; Schinazi, R. F.; Liotta, D. C. A Completely Diastereoselective Electrophilic Fluorination of a Chiral, Noncarbohydrate Sugar Ring Precursor: Application to the Synthesis of Several Novel 2'-Fluoronucleosides. J. Org. Chem. 1998, 63, 2161-2167.

10. Lee, K.; Choi, Y.; Gumina, G.; Zhou, W.; Schinazi, R. F.; Chu, C. K. Structureactivity relationships of 2'-fluoro-2',3'-unsaturated D-nucleosides as anti-HIV-1 agents. J Med Chem 2002, 45, 1313-20.

11. Zhou, W.; Gumina, G.; Chong, Y.; Wang, J.; Schinazi, R. F.; Chu, C. K. Synthesis, structure-activity relationships, and drug resistance of beta-d-3'-fluoro2',3'-unsaturated nucleosides as anti-HIV Agents. J. Med. Chem. 2004, 47, 33993408 .

12. Wang, J.; Lohman, G. J. S.; Stubbe, J. Enhanced subunit interactions with gemcitabine-5 '-diphosphate inhibit ribonucleotide reductases. Proc. Natl. Acad. Sci. USA 2007, 104, 14324-14329. 
13. Heidelberger, C.; Chaudhuri, N. K.; Danneberg, P.; Mooren, D.; Griesbach, L.; Duschinsky, R.; Schnitzer, R. J.; Pleven, E.; Scheiner, J. Fluorinated pyrimidines, a new class of tumour-inhibitory compounds. Nature 1957, 179, 663-666.

14. Hertel, L. W.; Kroin, J. S.; Misner, J. W.; Tustin, J. M. Synthesis of 2-deoxy-2,2difluoro-D-ribose and 2-deoxy-2,2'-difluoro-D-ribofuranosyl nucleosides. J. Org. Chem. 1988, 53, 2406-2409.

15. Carmichael, J.; Fink, U.; Russell, R. C. G.; Spittle, M. F.; Harris, A. L.; Spiessi, G.; Blatter, J. Phase II study of gemcitabine in patients with advanced pancreatic cancer. Brit. J. Cancer 1996, 73, 101-105.

16. Hidalgo, M.; Castellano, D.; Paz-Ares, L.; Gravalos, C.; Diaz-Puente, M.; Hitt, R.; Alonso, S.; Cortes-Funes, H. Phase I-II study of gemcitabine and fluorouracil as a continuous infusion in patients with pancreatic cancer. J. Clin. Oncol. 1999, $17,585-592$.

17. Eli Lilly and Company Gemzar (Gemcitabine $\mathrm{HCl}$ ) for injectin 2005.http://www.fda.gov/ohrms/dockets/ac/06/briefing/20064254b_11_04_KP\%20GemcitabineFDAlabel42005.pdf; accessed 01-15-2014.

18. Gesto, D. S.; Cerqueira, N. M.; Fernandes, P. A.; Ramos, M. J. Gemcitabine: a critical nucleoside for cancer therapy. Curr. Med. Chem. 2012, 19, 1076-1087.

19. von der Maase, H.; Hansen, S. W.; Roberts, J. T.; Dogliotti, L.; Oliver, T.; Moore, M. J.; Bodrogi, I.; Albers, P.; Knuth, A.; Lippert, C. M.; Kerbrat, P.; Sanchez Rovira, P.; Wersall, P.; Cleall, S. P.; Roychowdhury, D. F.; Tomlin, I.; VisserenGrul, C. M.; Conte, P. F. Gemcitabine and cisplatin versus methotrexate, vinblastine, doxorubicin, and cisplatin in advanced or metastatic bladder cancer: results of a large, randomized, multinational, multicenter, phase III study. J. Clin. Oncol. 2000, 18, 3068-3077.

20. Silvestris, N.; Cinieri, S.; La Torre, I.; Pezzella, G.; Numico, G.; Orlando, L.; Lorusso, V. Role of gemcitabine in metastatic breast cancer patients: A short review. The Breast 2008, 17, 220-226.

21. Blackstein, M.; Vogel, C. L.; Ambinder, R.; Cowan, J.; Iglesias, J.; Melemed, A. Gemcitabine as First-Line Therapy in Patients with Metastatic Breast Cancer: A Phase II Trial. Oncol. 2002, 62, 2-8.

22. Burris, H. A.; Moore, M. J.; Andersen, J.; Green, M. R.; Rothenberg, M. L.; Madiano, M. R.; Cripps, M. C.; Portenoy, R. K.; Storniolo, A. M.; Tarassoff, P.; Nelson, R.; Dorr, F. A.; Stephens, C. D.; VanHoff, D. D. Improvements in survival and clinical benefit with gemcitabine as first-line therapy for patients 
with advanced pancreas cancer: A randomized trial. J. Clin. Oncol. 1997, 15, 2403-2413.

23. Moore, M. J.; Goldstein, D.; Hamm, J.; Figer, A.; Hecht, J. R.; Gallinger, S.; Au, H. J.; Murawa, P.; Walde, D.; Wolff, R. A.; Campos, D.; Lim, R.; Ding, K.; Clark, G.; Voskoglou-Nomikos, T.; Ptasynski, M.; Parulekar, W. Erlotinib plus gemcitabine compared with gemcitabine alone in patients with advanced pancreatic cancer: A phase III trial of the National Cancer Institute of Canada clinical trials group. J. Clin. Oncol. 2007, 25, 1960-1966.

24. Sandler, A. B.; Nemunaitis, J.; Denham, C.; von Pawel, J.; Cormier, Y.; Gatzemeier, U.; Mattson, K.; Manegold, C.; Palmer, M. C.; Gregor, A.; Nguyen, B.; Niyikiza, C.; Einhorn, L. H. Phase III trial of gemcitabine plus cisplatin versus cisplatin alone in patients with locally advanced or metastatic non-small-cell lung cancer. J. Clin. Oncol. 2000, 18, 122-130.

25. Anderson, H.; Lund, B.; Bach, F.; Thatcher, N.; Walling, J.; Hansen, H. H. Single-Agent Activity of Weekly Gemcitabine in Advanced Non-Small-Cell Lung-Cancer - a Phase-Ii Study. J. Clin. Oncol. 1994, 12, 1821-1826.

26. Toschi, L.; Finocchiaro, G.; Bartolini, S.; Gioia, V.; Cappuzzo, F. Role of gemcitabine in cancer therapy. Future Oncol. 2005, 1, 7-17.

27. Toschi, L.; Cappuzzo, F. Gemcitabine for the treatment of advanced nonsmall cell lung cancer. Oncotargets Ther. 2009, 2, 209-217.

28. Mini, E.; Nobili, S.; Caciagli, B.; Landini, I.; Mazzei, T. Cellular pharmacology of gemcitabine. Ann. Oncol. 2006, 17, 7-12.

29. Rauchwerger, D. R.; Firby, P. S.; Hedley, D. W.; Moore, M. J. Equilibrativesensitive nucleoside transporter and its role in gemcitabine sensitivity. Cancer Res. 2000, 60, 6075-6079.

30. Mackey, J. R.; Mani, R. S.; Selner, M.; Mowles, D.; Young, J. D.; Belt, J. A.; Crawford, C. R.; Cass, C. E. Functional nucleoside transporters are required for gemcitabine influx and manifestation of toxicity in cancer cell lines. Cancer Res. 1998, 58, 4349-4357.

31. Achiwa, H.; Oguri, T.; Sato, S.; Maeda, H.; Niimi, T.; Ueda, R. Determinants of sensitivity and resistance to gemcitabine: The roles of human equilibrative nucleoside transporter 1 and deoxycytidine kinase in non-small cell lung cancer. Cancer Sci. 2004, 95, 753-757.

32. Mori, R.; Ishikawa, T.; Ichikawa, Y.; Taniguchi, K.; Matsuyama, R.; Ueda, M.; Fujii, Y.; Endo, I.; Togo, S.; Danenberg, P. V.; Shimada, H. Human equilibrative 
nucleoside transporter 1 is associated with the chemosensitivity of gemcitabine in human pancreatic adenocarcinoma and biliary tract carcinoma cells. Oncol. Reports 2007, 17, 1201-1205.

33. Marechal, R.; Mackey, J. R.; Lai, R.; Demetter, P.; Peeters, M.; Polus, M.; Cass, C. E.; Young, J.; Salmon, I.; Deviere, J.; Van Laethem, J. L. Human equilibrative nucleoside transporter 1 and human concentrative nucleoside transporter 3 predict survival after adjuvant gemcitabine therapy in resected pancreatic adenocarcinoma. Clin. Cancer Res. 2009, 15, 2913-9.

34. Giovannetti, E.; Del Tacca, M.; Mey, V.; Funel, N.; Nannizzi, S.; Ricci, S.; Orlandini, C.; Boggi, U.; Campani, D.; Del Chiaro, M.; Iannopollo, M.; Bevilacqua, G.; Mosca, F.; Danesi, R. Transcription analysis of human equilibrative nucleoside transporter-1 predicts survival in pancreas cancer patients treated with gemcitabine. Cancer Res. 2006, 66, 3928-3935.

35. Gandhi, V.; Plunkett, W. Modulatory Activity of 2',2'-Difluorodeoxycytidine on the Phosphorylation and Cytotoxicity of Arabinosyl Nucleosides. Cancer Res. 1990, 50, 3675-3680.

36. Huang, P.; Chubb, S.; Hertel, L. W.; Grindey, G. B.; Plunkett, W. Action of 2',2'Difluorodeoxycytidine on DNA-Synthesis. Cancer Res. 1991, 51, 6110-6117.

37. Kroep, J. R.; van Moorsel, C. J.; Veerman, G.; Voorn, D. A.; Schultz, R. M.; Worzalla, J. F.; Tanzer, L. R.; Merriman, R. L.; Pinedo, H. M.; Peters, G. J. Role of deoxycytidine kinase (dCK), thymidine kinase 2 (TK2), and deoxycytidine deaminase (dCDA) in the antitumor activity of gemcitabine (dFdC). Adv. Exp. Med. Biol. 1998, 431, 657-660.

38. Kroep, J. R.; Loves, W. J. P.; van der Wilt, C. L.; Alvarez, E.; Talianidis, L.; Boven, E.; Braakhuis, B. J. M.; van Groeningen, C. J.; Pinedo, H. M.; Peters, G. J. Pretreatment deoxycytidine kinase levels predict in vivo gemcitabine sensitivity. Mol. Cancer Ther. 2002, 1, 371-376.

39. Laing, R. E.; Walter, M. A.; Campbell, D. O.; Herschman, H. R.; Satyamurthy, N.; Phelps, M. E.; Czernin, J.; Witte, O. N.; Radu, C. G. Noninvasive prediction of tumor responses to gemcitabine using positron emission tomography. Proc. Natl. Acad. Sci. 2009, 106, 2847-2852.

40. Saiki, Y.; Yoshino, Y.; Fujimura, H.; Manabe, T.; Kudo, Y.; Shimada, M.; Mano, N.; Nakano, T.; Lee, Y.; Shimizu, S.; Oba, S.; Fujiwara, S.; Shimizu, H.; Chen, N.; Nezhad, Z. K.; Jin, G.; Fukushige, S.; Sunamura, M.; Ishida, M.; Motoi, F.; Egawa, S.; Unno, M.; Horii, A. DCK is frequently inactivated in acquired gemcitabine-resistant human cancer cells. Biochem. Biophys. Res. Commun. 2012, 421, 98-104. 
41. Plunkett, W.; Huang, P.; Gandhi, V. Preclinical characteristics of gemcitabine. Anti-Cancer Drugs 1995, 6, 7-13.

42. Heinemann, V.; Schulz, L.; Issels, R. D.; Plunkett, W. Gemcitabine: a modulator of intracellular nucleotide and deoxynucleotide metabolism. Semin. Oncol. 1995, 22, 11-18.

43. Ruiz van Haperen, V. W. T.; Veerman, G.; Vermorken, J. B.; Peters, G. J. 2',2'Difluoro-deoxycytidine (gemcitabine) incorporation into RNA and DNA of tumour cell lines. Biochem. Pharmacol. 1993, 46, 762-766.

44. Heinemann, V.; Xu, Y. Z.; Chubb, S.; Sen, A.; Hertel, L. W.; Grindey, G. B.; Plunkett, W. Inhibition of ribonucleotide reduction in CCRF-CEM cells by 2',2'difluorodeoxycytidine. Mol. Pharm. 1990, 38, 567-572.

45. Plunkett, W.; Huang, P.; Xu, Y.-Z.; Heinemann, V.; Grunewald, R.; Gandhi, V. Gemcitabine: metabolism, mechanisms of action, and self-potentiation. Semin. Oncol. 1995, 22, 3-10.

46. Baker, C. H.; Banzon, J.; Bollinger, J. M.; Stubbe, J.; Samano, V.; Robins, M. J.; Lippert, B.; Jarvi, E.; Resvick, R. 2'-Deoxy-2'-methylenecytidine and 2'-deoxy2',2'-difluorocytidine 5'-diphosphates: potent mechanism-based inhibitors of ribonucleotide reductase. J. Med. Chem. 1991, 34, 1879-1884.

47. Silva, D. J.; Stubbe, J.; Samano, V.; Robins, M. J. Gemcitabine 5 '-triphosphate is a stoichiometric mechanism-based inhibitor of Lactobacillus leichmannii ribonucleoside triphosphate reductase: Evidence for thiyl radical-mediated nucleotide radical formation. Biochemistry 1998, 37, 5528-5535.

48. van der Donk, W. A.; Yu, G. X.; Perez, L.; Sanchez, R. J.; Stubbe, J.; Samano, V.; Robins, M. J. Detection of a new substrate-derived radical during inactivation of ribonucleotide reductase from Escherichia coli by gemcitabine 5 '-diphosphate. Biochemistry 1998, 37, 6419-6426.

49. Wang, J.; Lohman, G. J. S.; Stubbe, J. Mechanism of Inactivation of Human Ribonucleotide Reductase with p53R2 by Gemcitabine 5 '-Diphosphate. Biochemistry 2009, 48, 11612-11621.

50. Artin, E.; Wang, J.; Lohman, G. J. S.; Yokoyama, K.; Yu, G. X.; Griffin, R. G.; Bar, G.; Stubbe, J. Insight into the Mechanism of Inactivation of Ribonucleotide Reductase by Gemcitabine 5 '-Diphosphate in the Presence or Absence of Reductant. Biochemistry 2009, 48, 11622-11629.

51. Eklund, H.; Uhlin, U.; Farnegardh, M.; Logan, D. T.; Nordlund, P. Structure and function of the radical enzyme ribonucleotide reductase. Prog. Biophys. Mol. Bio. 2001, 77, 177-268. 
52. Stubbe, J.; van der Donk, W. A. Ribonucleotide reductases: radical enzymes with suicidal tendencies. Chem. Biol. 1995, 2, 793-801.

53. Shipley, L. A.; Brown, T. J.; Cornpropst, J. D.; Hamilton, M.; Daniels, W. D.; Culp, H. W. Metabolism and disposition of gemcitabine, and oncolytic deoxycytidine analog, in mice, rats, and dogs. Drug Metab. Dispos. 1992, 20, 849-855.

54. Veltkamp, S. A.; Pluim, D.; van Eijndhoven, M. A. J.; Bolijn, M. J.; Ong, F. H. G.; Govindarajan, R.; Unadkat, J. D.; Beijnen, J. H.; Schellens, J. H. M. New insights into the pharmacology and cytotoxicity of gemcitabine and 2 ',2 'difluorodeoxyuridine. Mol. Cancer Ther. 2008, 7, 2415-2425.

55. Fujita, H.; Ohuchida, K.; Mizumoto, K.; Itaba, S.; Ito, T.; Nakata, K.; Yu, J.; Kayashima, T.; Souzaki, R.; Tajiri, T.; Manabe, T.; Ohtsuka, T.; Tanaka, M. Gene Expression Levels as Predictive Markers of Outcome in Pancreatic Cancer after Gemcitabine-Based Adjuvant Chemotherapy. Neoplasia 2010, 12, 807-U161.

56. Duxbury, M. S.; Ito, H.; Zinner, M. J.; Ashley, S. W.; Whang, E. E. RNA interference targeting the M2 subunit of ribonucleotide reductase enhances pancreatic adenocarcinoma chemosensitivity to gemcitabine. Oncogene 2004, 23, 1539-1548.

57. Patel, S. R.; Gandhi, V.; Jenkins, J.; Papadopolous, N.; Burgess, M. A.; Plager, C.; Plunkett, W.; Benjamin, R. S. Phase II clinical investigation of gemcitabine in advanced soft tissue sarcomas and window evaluation of dose rate on gemcitabine triphosphate accumulation. J. Clin. Oncol. 2001, 19, 3483-3489.

58. Gandhi, V.; Plunkett, W.; Du, M.; Ayres, M.; Estey, E. H. Prolonged infusion of gemcitabine: clinical and pharmacodynamic studies during a phase I trial in relapsed acute myelogenous leukemia. J. Clin. Oncol. 2002, 20, 665-673.

59. Veltkamp, S. A.; Beijnen, J. H.; Schellens, J. H. M. Prolonged versus standard gemcitabine infusion: Translation of molecular pharmacology to new treatment strategy. Oncologist 2008, 13, 261-276.

60. Jordheim, L. P.; Durantel, D.; Zoulim, F.; Dumontet, C. Advances in the development of nucleoside and nucleotide analogues for cancer and viral diseases. Nat. Rev. Drug Discov. 2013, 12, 447-464.

61. Myhren, F.; Borretzen, B.; Dalen, A.; Sandvold, M. L. Gemcitabine derivatives Patent Application WO 98/32762, 1998. 
62. Immordino, M. L.; Brusa, P.; Rocco, F.; Arpicco, S.; Ceruti, M.; Cattel, L. Preparation, characterization, cytotoxicity and pharmacokinetics of liposomes containing lipophilic gemcitabine prodrugs. J. Controlled Release 2004, 100, 331346.

63. Stella, B.; Arpicco, S.; Rocco, F.; Marsaud, V.; Renoir, J. M.; Cattel, L.; Couvreur, P. Encapsulation of gemcitabine lipophilic derivatives into polycyanoacrylate nanospheres and nanocapsules. Int. J. Pharm. 2007, 344, 71-7.

64. Chung, W. G.; Sandoval, M. A.; Sloat, B. R.; Lansakara, D. S. P.; Cui, Z. R. Stearoyl gemcitabine nanoparticles overcome resistance related to the overexpression of ribonucleotide reductase subunit M1. J. Controlled Release 2012, $157,132-140$.

65. Couvreur, P.; Stella, B.; Reddy, L. H.; Hillaireau, H.; Dubernet, C.; Desmaele, D.; Lepetre-Mouelhi, S.; Rocco, F.; Dereuddre-Bosquet, N.; Clayette, P.; Rosilio, V.; Marsaud, V.; Renoir, J. M.; Cattel, L. Squalenoyl Nanomedicines as Potential Therapeutics. Nano Lett. 2006, 6, 2544-2548.

66. Bildstein, L.; Dubernet, C.; Marsaud, V.; Chacun, H.; Nicolas, V.; Gueutin, C.; Sarasin, A.; Benech, H.; Lepetre-Mouelhi, S.; Desmaele, D.; Couvreur, P. Transmembrane diffusion of gemcitabine by a nanoparticulate squalenoyl prodrug: An original drug delivery pathway. J. Controlled Release 2010, 147, 163-170.

67. Reddy, L. H.; Dubernet, C.; Mouelhi, S. L.; Marque, P. E.; Desmaele, D.; Couvreur, P. A new nanomedicine of gemcitabine displays enhanced anticancer activity in sensitive and resistant leukemia types. J. Controlled Release 2007, 124, 20-27.

68. Rejiba, S.; Reddy, L. H.; Bigand, C.; Parmentier, C.; Couvreur, P.; Hajri, A. Squalenoyl gemcitabine nanomedicine overcomes the low efficacy of gemcitabine therapy in pancreatic cancer. Nanomed-Nanotechnol. 2011, 7, 841-849.

69. Bender, D. M.; Bao, J. Q.; Dantzig, A. H.; Diseroad, W. D.; Law, K. L.; Magnus, N. A.; Peterson, J. A.; Perkins, E. J.; Pu, Y. W. J.; Reutzel-Edens, S. M.; Remick, D. M.; Starling, J. J.; Stephenson, G. A.; Vaid, R. K.; Zhang, D. Y.; McCarthy, J. R. Synthesis, Crystallization, and Biological Evaluation of an Orally Active Prodrug of Gemcitabine. J. Med. Chem. 2009, 52, 6958-6961.

70. Koolen, S. L.; Witteveen, P. O.; Jansen, R. S.; Langenberg, M. H.; Kronemeijer, R. H.; Nol, A.; Garcia-Ribas, I.; Callies, S.; Benhadji, K. A.; Slapak, C. A.; Beijnen, J. H.; Voest, E. E.; Schellens, J. H. Phase I study of Oral gemcitabine prodrug (LY2334737) alone and in combination with erlotinib in patients with advanced solid tumors. Clin. Cancer Res. 2011, 17, 6071-6082. 
71. Pratt, S. E.; Durland-Busbice, S.; Shepard, R. L.; Heinz-Taheny, K.; Iversen, P. W.; Dantzig, A. H. Human Carboxylesterase-2 Hydrolyzes the Prodrug of Gemcitabine (LY2334737) and Confers Prodrug Sensitivity to Cancer Cells. Clin. Cancer Res. 2013, 19, 1159-1168.

72. Wickremsinhe, E.; Bao, J.; Smith, R.; Burton, R.; Dow, S.; Perkins, E. Preclinical Absorption, Distribution, Metabolism, and Excretion of an Oral Amide Prodrug of Gemcitabine Designed to Deliver Prolonged Systemic Exposure. Pharmaceutics 2013, 5, 261-276.

73. Vandana, M.; Sahoo, S. K. Long circulation and cytotoxicity of PEGylated gemcitabine and its potential for the treatment of pancreatic cancer. Biomaterials 2010, 31, 9340-9356.

74. Pasut, G.; Canal, F.; Via, L. D.; Arpicco, S.; Veronese, F. A.; Schiavon, O. Antitumoral activity of PEG-gemcitabine prodrugs targeted by folic acid. $J$. Controlled Release 2008, 127, 239-248.

75. Bergman, A. M.; Adema, A. D.; Balzarini, J.; Bruheim, S.; Fichtner, I.; Noordhuis, P.; Fodstad, O.; Myhren, F.; Sandvold, M. L.; Hendriks, H. R.; Peters, G. J. Antiproliferative activity, mechanism of action and oral antitumor activity of CP-4126, a fatty acid derivative of gemcitabine, in in vitro and in vivo tumor models. Invest. New Drugs 2011, 29, 456-466.

76. Sandvold, M. L.; Galmarini, C.; Myhren, F.; Peters, G. The Activity of the Lipophilic Nucleoside Derivatives Elacytarabine and CP-4126 in a Panel of Tumor Cell Lines Resistant to Nucleoside Analogues. Nucleos. Nucleot. Nucl. 2010, 29, 386-393.

77. Stuurman, F. E.; Voest, E. E.; Awada, A.; Witteveen, P. O.; Bergeland, T.; Hals, P. A.; Rasch, W.; Schellens, J. H.; Hendlisz, A. Phase I study of oral CP-4126, a gemcitabine derivative, in patients with advanced solid tumors. Invest. New Drugs 2013, 31, 959-966.

78. Poplin, E.; Wasan, H.; Rolfe, L.; Raponi, M.; Ikdahl, T.; Bondarenko, I.; Davidenko, I.; Bondar, V.; Garin, A.; Boeck, S.; Ormanns, S.; Heinemann, V.; Bassi, C.; Evans, T. R.; Andersson, R.; Hahn, H.; Picozzi, V.; Dicker, A.; Mann, E.; Voong, C.; Kaur, P.; Isaacson, J.; Allen, A. Randomized, Multicenter, Phase II Study of CO-101 Versus Gemcitabine in Patients With Metastatic Pancreatic Ductal Adenocarcinoma: Including a Prospective Evaluation of the Role of hENT1 in Gemcitabine or CO-101 Sensitivity. J. Clin. Oncol. 2013, 31, 4453-61. 
79. Dasari, M.; Acharya, A. P.; Kim, D.; Lee, S.; Lee, S.; Rhea, J.; Molinaro, R.; Murthy, N. H-Gemcitabine: A New Gemcitabine Prodrug for Treating Cancer. Bioconjugate Chem. 2013, 24, 4-8.

80. Maiti, S.; Park, N.; Han, J. H.; Jeon, H. M.; Lee, J. H.; Bhuniya, S.; Kang, C.; Kim, J. S. Gemcitabine-Coumarin-Biotin Conjugates: A Target Specific Theranostic Anticancer Prodrug. J. Am. Chem. Soc. 2013, 135, 4567-4572.

81. Bhuniya, S.; Lee, M. H.; Jeon, H. M.; Han, J. H.; Lee, J. H.; Park, N.; Maiti, S.; Kang, C.; Kim, J. S. A fluorescence off-on reporter for real time monitoring of gemcitabine delivery to the cancer cells. Chem. Commun. 2013, 49, 7141-7143.

82. Wu, C. Y.; Wang, H. E.; Lin, M. H.; Chu, L. S.; Liu, R. S. Radiolabeled Nucleosides for Predicting and Monitoring the Cancer Therapeutic Efficacy of Chemodrugs. Curr. Med. Chem. 2012, 19, 3315-3324.

83. Phelps, M. E. Positron emission tomography provides molecular imaging of biological processes. Proc. Natl. Acad. Sci. USA 2000, 97, 9226-9233.

84. Gambhir, S. S. Molecular imaging of cancer with positron emission tomography. Nat. Rev. Cancer 2002, 2, 683-693.

85. Schlyer, D. J. PET tracers and radiochemistry. Ann. Acad. Med. Singap. 2004, 33, 146-154.

86. Alauddin, M. M. Positron emission tomography (PET) imaging with (18)F-based radiotracers. Am. J. Nuc. Med. Mol. Imaging 2012, 2, 55-76.

87. $\mathrm{Yu}, \mathrm{S}$. Review of F-FDG Synthesis and Quality Control. Biomed. Imaging Interv. J. 2006, 2, e57.

88. Beuthien-Baumann, B.; Hamacher, K.; Oberdorfer, F.; Steinbach, J. Preparation of fluorine-18 labelled sugars and derivatives and their application as tracer for positron-emission-tomography. Carbohydr. Res 2000, 327, 107-118.

89. Fowler, J. S.; Ido, T. Initial and subsequent approach for the synthesis of 18FDG. Semin. Nucl. Med. 2002, 32, 6-12.

90. Ehrenkaufer, R. E.; Potocki, J. F.; Jewett, D. M. Simple Synthesis of F-18Labeled 2-Fluoro-2-Deoxy-D-Glucose - Concise Communication. J. Nucl. Med. 1984, 25, 333-337.

91. Vallabhajosula, S.; SpringerLink, Molecular imaging radiopharmaceuticals for PET and SPECT. Springer-Verlag: Berlin ; Heidelberg, 2009. 
92. $\mathrm{Yu}, \mathrm{S}$. Review of F-FDG Synthesis and Quality Control. Biomed. Imaging Interv. J. 2006, 2, e57.

93. Choi, S. J.; Kim, J. S.; Kim, J. H.; Oh, S. J.; Lee, J. G.; Kim, C. J.; Ra, Y. S.; Yeo, J. S.; Ryu, J. S.; Moon, D. H. [18F]3'-deoxy-3'-fluorothymidine PET for the diagnosis and grading of brain tumors. Eur. J. Nucl. Med. Mol. Imaging 2005, 32, 653-659.

94. Chen, W.; Cloughesy, T.; Kamdar, N.; Satyamurthy, N.; Bergsneider, M.; Liau, L.; Mischel, P.; Czernin, J.; Phelps, M. E.; Silverman, D. H. Imaging proliferation in brain tumors with 18F-FLT PET: comparison with 18F-FDG. J. Nucl. Med. 2005, 46, 945-952.

95. Saga, T.; Kawashima, H.; Araki, N.; Takahashi, J. A.; Nakashima, Y.; Higashi, T.; Oya, N.; Mukai, T.; Hojo, M.; Hashimoto, N.; Manabe, T.; Hiraoka, M.; Togashi, K. Evaluation of primary brain tumors with FLT-PET: usefulness and limitations. Clin. Nucl. Med. 2006, 31, 774-780.

96. Kenny, L. M.; Vigushin, D. M.; Al-Nahhas, A.; Osman, S.; Luthra, S. K.; Shousha, S.; Coombes, R. C.; Aboagye, E. O. Quantification of cellular proliferation in tumor and normal tissues of patients with breast cancer by [18F]fluorothymidine-positron emission tomography imaging: evaluation of analytical methods. Cancer Res. 2005, 65, 10104-12.

97. Wu, C. Y.; Wang, H. E.; Lin, M. H.; Chu, L. S.; Liu, R. S. Radiolabeled nucleosides for predicting and monitoring the cancer therapeutic efficacy of chemodrugs. Curr. Med. Chem. 2012, 19, 3315-24.

98. Rasey, J. S.; Grierson, J. R.; Wiens, L. W.; Kolb, P. D.; Schwartz, J. L. Validation of FLT uptake as a measure of thymidine kinase-1 activity in A549 carcinoma cells. J. Nucl. Med. 2002, 43, 1210-1217.

99. Lu, L.; Samuelsson, L.; Bergstrom, M.; Sato, K.; Fasth, K. J.; Langstrom, B. Rat studies comparing $\mathrm{C}-11-\mathrm{FMAU}, \mathrm{F}-18-\mathrm{FLT}$, and $\mathrm{Br}-76-\mathrm{BFU}$ as proliferation markers. J. Nucl. Med. 2002, 43, 1688-1698.

100. Vesselle, H.; Grierson, J.; Muzi, M.; Pugsley, J. M.; Schmidt, R. A.; Rabinowitz, P.; Peterson, L. M.; Vallieres, E.; Wood, D. E. In vivo validation of 3 ' deoxy-3 '[F-18]fluorothymidine ([F-18]FLT) as a proliferation imaging tracer in humans: Correlation of [F-18]FLT uptake by positron emission tomography with Ki-67 immunohistochemistry and flow cytometry in human lung tumors. Clin. Cancer Res. 2002, 8, 3315-3323.

101. Pio, B. S.; Park, C. K.; Pietras, R.; Hsueh, W. A.; Satyamurthy, N.; Pegram, M. D.; Czernin, J.; Phelps, M. E.; Silverman, D. H. S. Usefulness of 3 '-[F-18]fluoro- 
3 '-deoxythymidine with positron emission tomography in predicting breast cancer response to therapy. Mol. Imaging Biol. 2006, 8, 36-42.

102. Buck, A. K.; Halter, G.; Schirrmeister, H.; Kotzerke, J.; Wurziger, I.; Glatting, G.; Mattfeldt, T.; Neumaier, B.; Reske, S. N.; Hetzel, M. Imaging proliferation in lung tumors with PET: F-18-FLT versus F-18-FDG. J. Nucl. Med. 2003, 44, 1426-1431.

103. Wilson, I. K.; Chatterjee, S.; Wolf, W. Synthesis of 3'-Fluoro-3'-Deoxythymidine and Studies of Its F-18 Radiolabeling, as a Tracer for the Noninvasive Monitoring of the Biodistribution of Drugs against Aids. J. Fluorine Chem. 1991, 55, 283289.

104. Grierson, J. R.; Shields, A. F. Radiosynthesis of 3 '-deoxy-3 '-[F18]fluorothymidine: [F-18]FLT for imaging of cellular proliferation in vivo. Nucl. Med. Biol. 2000, 27, 143-156.

105. Pascali, C.; Bogni, A.; Fugazza, L.; Cucchi, C.; Crispu, O.; Laera, L.; Iwata, R.; Maiocchi, G.; Crippa, F.; Bombardieri, E. Simple preparation and purification of ethanol-free solutions of $3^{\prime}$-deoxy-3'-[18F]fluorothymidine by means of disposable solid-phase extraction cartridges. Nucl. Med. Biol. 2012, 39, 540-550.

106. Kim, D. W.; Ahn, D. S.; Oh, Y. H.; Lee, S.; Kil, H. S.; Oh, S. J.; Lee, S. J.; Kim, J. S.; Ryu, J. S.; Moon, D. H.; Chi, D. Y. A new class of $\mathrm{S}(\mathrm{N}) 2$ reactions catalyzed by protic solvents: Facile fluorination for isotopic labeling of diagnostic molecules. J. Am. Chem. Soc. 2006, 128, 16394-16397.

107. Suehiro, M.; Vallabhajosula, S.; Goldsmith, S. J.; Ballon, D. J. Investigation of the role of the base in the synthesis of [F-18]FLT. Appl. Radiat. Isotopes 2007, $65,1350-1358$.

108. Sun, H. H.; Sloan, A.; Mangner, T. J.; Vaishampayan, U.; Muzik, O.; Collins, J. M.; Douglas, K.; Shields, A. F. Imaging DNA synthesis with [F-18]FMAU and positron emission tomography in patients with cancer. Eur. J. Nucl. Med. Mol. I. 2005, 32, 15-22.

109. Bading, J. R.; Shieds, A. F. Imaging of cell proliferation: Status and prospects. J. Nucl. Med. 2008, 49, 64-80.

110. Tehrani, O. S.; Muzik, O.; Heilbrun, L. K.; Douglas, K. A.; Lawhorn-Crews, J. M.; Sun, H. H.; Mangner, T. J.; Shields, A. F. Tumor imaging using 1-(2 '-deoxy2 '-F-18-fluoro-beta-D-arabinofuranosyl)thymine and PET. J. Nucl. Med. 2007, $48,1436-1441$. 
111. Alauddin, M. M.; Conti, P. S.; Fissekis, J. D. Synthesis of [F-18]-labeled 2 'deoxy-2 '-fluoro-5-methyl-1-beta-D-arabinofuranosyluracil ([F-18]-FMAU). $J$. Labelled Compd. Rad. 2002, 45, 583-590.

112. Alauddin, M. M.; Shahinian, A.; Fissekis, J. D.; Conti, P. S. Synthesis of high specific activity 2 '-deoxy-2 '-F-18-fluoro-5-fluoro-1-beta-Darabinofuranosyluracil (F-18-FFAU) and its preliminary evaluation as a potential gene imaging agent. J. Nucl. Med. 2002, 43, 89p-89.

113. Paolillo, V.; Riese, S.; Gelovani, J. G.; Alauddin, M. M. A fully automated synthesis of [F-18]-FEAU and [F-18]-FMAU using a novel dual reactor radiosynthesis module. J. Labelled Compd. Rad. 2009, 52, 553-558.

114. Li, Z. B.; Cai, H. C.; Conti, P. S. Automated synthesis of 2 '-deoxy-2 '-[F18]fluoro-5-methyl-1-beta-D-arabinofuranosyluracil ([F-18]-FMAU) using a one reactor radiosynthesis module. Nucl. Med. Biol. 2011, 38, 201-206.

115. Radu, C. G.; Shu, C. J.; Nair-Gill, E.; Shelly, S. M.; Barrio, J. R.; Satyamurthy, N.; Phelps, M. E.; Witte, O. N. Molecular imaging of lymphoid organs and immune activation by positron emission tomography with a new [18F]-labeled 2'deoxycytidine analog. Nat. Med. 2008, 14, 783-8.

116. Laing, R. E.; Walter, M. A.; Campbell, D. O.; Herschman, H. R.; Satyamurthy, N.; Phelps, M. E.; Czernin, J.; Witte, O. N.; Radu, C. G. Noninvasive prediction of tumor responses to gemcitabine using positron emission tomography. P. Natl. Acad. Sci. USA 2009, 106, 2847-2852.

117. Radu, C. G.; Shu, C. J.; Nair-Gill, E.; Shelly, S. M.; Barrio, J. R.; Satyamurthy, N.; Phelps, M. E.; Witte, O. N. Molecular imaging of lymphoid organs and immune activation by positron emission tomography with a new [(18)F]-labeled 2 '-deoxycytidine analog. Nat. Med. 2008, 14, 783-788.

118. Schwarzenberg, J.; Radu, C. G.; Benz, M.; Fueger, B.; Tran, A. Q.; Phelps, M. E.; Witte, O. N.; Satyamurthy, N.; Czernin, J.; Schiepers, C. Human biodistribution and radiation dosimetry of novel PET probes targeting the deoxyribonucleoside salvage pathway. Eur. J. Nucl. Med. Mol. I. 2011, 38, 711-721.

119. Brechbiel, M. W. Bifunctional chelates for metal nuclides. J. Nucl. Med. Mol. Imaging 2008, 52, 166-173.

120. Green, M. A.; Welch, M. J. Gallium Radiopharmaceutical Chemistry. Nucl. Med. Biol. 1989, 16, 435-439

121. Hedley, D. W.; Tripp, E. H.; Slowiaczek, P.; Mann, G. J. Effect of gallium on DNA synthesis by human T-cell lymphoblasts. Cancer Res. 1988, 48, 3014-8. 
122. Haq, R. U.; Wereley, J. P.; Chitambar, C. R. Induction of apoptosis by iron deprivation in human leukemic CCRF-CEM cells. Exp. Hematol. 1995, 23, 42832.

123. Chitambar, C. R.; Narasimhan, J.; Guy, J.; Sem, D. S.; O'Brien, W. J. Inhibition of ribonucleotide reductase by gallium in murine leukemic L1210 cells. Cancer Res. 1991, 51, 6199-201.

124. Leyland-Jones, B. Treating cancer-related hypercalcemia with gallium nitrate. Supportive Oncol. 2004, 2, 509-16.

125. Hata, Y.; Sandler, A.; Loehrer, P. J.; Sledge, G. W., Jr.; Weber, G. Synergism of taxol and gallium nitrate in human breast carcinoma cells: schedule dependency. Oncol. Res. 1994, 6, 19-24.

126. Lundberg, J. H.; Chitambar, C. R. Interaction of gallium nitrate with fludarabine and iron chelators: effects on the proliferation of human leukemic HL60 cells. Cancer Res. 1990, 50, 6466-70.

127. Chitambar, C. R.; Matthaeus, W. G.; Antholine, W. E.; Graff, K.; O'Brien, W. J. Inhibition of leukemic HL60 cell growth by transferrin-gallium: effects on ribonucleotide reductase and demonstration of drug synergy with hydroxyurea. Blood 1988, 72, 1930-6.

128. Myette, M. S.; Elford, H. L.; Chitambar, C. R. Interaction of gallium nitrate with other inhibitors of ribonucleotide reductase: effects on the proliferation of human leukemic cells. Cancer Lett. 1998, 129, 199-204.

129. Collery, P.; Domingo, J. L.; Keppler, B. K. Preclinical toxicology and tissue gallium distribution of a novel antitumour gallium compound: tris (8quinolinolato) gallium (III). Anticancer Res. 1996, 16, 687-91.

130. Bernstein, L. R.; Tanner, T.; Godfrey, C.; Noll, B. Chemistry and pharmacokinetics of gallium maltolate, a compound with high oral gallium bioavailability. Metal-based drugs 2000, 7, 33-47.

131. Ehrhardt, G. J.; Welch, M. J. A new germanium-63/gallium-68 generator. J. Nucl. Med. 1978, 19, 925-9.

132. Schuhmacher, J.; Maierborst, W. A New Ge-68-Ga-68 Radioisotope Generator System for Production of Ga-68 in Dilute Hcl. Int. J. Appl. Radiat. 1981, 32, 3136. 
133. Bartholomä, M. D. Recent developments in the design of bifunctional chelators for metal-based radiopharmaceuticals used in Positron Emission Tomography. Inorg. Chim. Acta 2012, 389, 36-51.

134. Andre, J. P.; Maecke, H. R.; Zehnder, M.; Macko, L.; Akyel, K. G. 1,4,7triazacyclononane-1-succinic acid-4,7-diacetic acid (NODASA): a new bifunctional chelator for radio gallium-labelling of biomolecules. Chem. Commun. 1998, 1301-1302.

135. Eisenwiener, K. P.; Prata, M. I. M.; Buschmann, I.; Zhang, H. W.; Santos, A. C.; Wenger, S.; Reubi, J. C.; Macke, H. R. NODAGATOC, a new chelator-coupled somatostatin analogue labeled with [Ga-67/68] and [In-111] for SPECT, PET, and targeted therapeutic applications of somatostatin receptor (hsst2) expressing tumors. Bioconjugate Chem. 2002, 13, 530-541.

136. Viola, N. A.; Rarig, R. S.; Ouellette, W.; Doyle, R. P. Synthesis, structure and thermal analysis of the gallium complex of 1,4,7,10-tetraazacyclo-dodecane-N,N ',N ",N "'-tetraacetic acid (DOTA). Polyhedron 2006, 25, 3457-3462.

137. Heppeler, A.; Froidevaux, S.; Macke, H. R.; Jermann, E.; Behe, M.; Powell, P.; Hennig, M. Radiometal-labelled macrocyclic chelator-derivatised somatostatin analogue with superb tumour-targeting properties and potential for receptormediated internal radiotherapy. Chem-Eur. J. 1999, 5, 1974-1981.

138. Kubicek, V.; Havlickova, J.; Kotek, J.; Gyula, T.; Hermann, P.; Toth, E.; Lukes, I. Gallium(III) Complexes of DOTA and DOTA-Monoamide: Kinetic and Thermodynamic Studies. Inorg. Chem. 2010, 49, 10960-10969.

139. Liu, S. Bifunctional coupling agents for radiolabeling of biomolecules and targetspecific delivery of metallic radionuclides. Ad. Drug Deliv. Rev. 2008, 60, 134770.

140. Breeman, W. A. P.; de Blois, E.; Chan, H. S.; Konijnenberg, M.; Kwekkeboom, D. J.; Krenning, E. P. Ga-68-labeled DOTA-Peptides and Ga-68-labeled Radiopharmaceuticals for Positron Emission Tomography: Current Status of Research, Clinical Applications, and Future Perspectives. Semin. Nucl. Med. 2011, 41, 314-321.

141. Gabriel, M.; Decristoforo, C.; Kendler, D.; Dobrozemsky, G.; Heute, D.; Uprimny, C.; Kovacs, P.; Von Guggenberg, E.; Bale, R.; Virgolini, I. J. Ga-68DOTA-Tyr(3)-octreotide PET in neuroendocrine tumors: Comparison with somatostatin receptor scintigraphy and CT. J. Nucl. Med. 2007, 48, 508-518. 
142. Liu, Z. F.; Yan, Y. J.; Liu, S. L.; Wang, F.; Chen, X. Y. F-18, Cu-64, and Ga-68 Labeled RGD-Bombesin Heterodimeric Peptides for PET Imaging of Breast Cancer. Bioconjugate Chem. 2009, 20, 1016-1025.

143. Jeong, J. M.; Hong, M. K.; Chang, Y. S.; Lee, Y. S.; Kim, Y. J.; Cheon, G. J.; Lee, D. S.; Chung, J. K.; Lee, M. C. Preparation of a promising angiogenesis PET imaging agent: 68Ga-labeled c(RGDyK)-isothiocyanatobenzyl-1,4,7triazacyclononane-1,4,7-triacetic acid and feasibility studies in mice. J. Nucl. Med. 2008, 49, 830-6.

144. Craft, J. M.; De Silva, R. A.; Lears, K. A.; Andrews, R.; Liang, K. X.; Achilefu, S.; Rogers, B. E. In vitro and in vivo evaluation of a Cu-64-labeled NOTA-BnSCN-Aoc-bombesin analogue in gastrin-releasing peptide receptor expressing prostate cancer. Nucl. Med. Biol. 2012, 39, 609-616.

145. Notni, J.; Pohle, K.; Wester, H. J. Comparative gallium-68 labeling of TRAP-, NOTA-, and DOTA-peptides: practical consequences for the future of gallium68-PET. EJNMMI Res. 2012, 2, 28.

146. Hong, H.; Zhang, Y.; Nayak, T. R.; Engle, J. W.; Wong, H. C.; Liu, B.; Barnhart, T. E.; Cai, W. B. Immuno-PET of Tissue Factor in Pancreatic Cancer. J. Nucl. Med. 2012, 53, 1748-1754.

147. Krajewska, E.; Shugar, D. Alkylated cytosine nucleosides: substrate and inhibitor properties in enzymatic deamination. Acta. Biochim. Pol. 1975, 22, 185-194.

148. Hertel, L. W.; Kroin, J. S. 2'-deoxy-2',2'-difluoro-(4-substituted pyrimidine) nucleosides having antiviral and anti-cancer activity and intermediates. European Patent EP/1993/576230, 1993.

149. Bender, D. M.; Bao, J.; Dantzig, A. H.; Diseroad, W. D.; Law, K. L.; Magnus, N. A.; Peterson, J. A.; Perkins, E. J.; Pu, Y. J.; Reutzel-Edens, S. M.; Remick, D. M.; Starling, J. J.; Stephenson, G. A.; Vaid, R. K.; Zhang, D.; McCarthy, J. R. Synthesis, Crystallization, and Biological Evaluation of an Orally Active Prodrug of Gemcitabine. J. Med. Chem. 2009, 52, 6958-6961.

150. Hugenberg, V.; Wagner, S.; Kopka, K.; Schober, O.; Schafers, M.; Haufe, G. Synthesis of geminal difluorides by oxidative desulfurization-difluorination of alkyl aryl thioethers with halonium electrophiles in the presence of fluorinating reagents and its application for $18 \mathrm{~F}$-radiolabeling. J. Org. Chem. 2010, 75, 60866095 .

151. Takahashi, T.; Mizuno, T.; Ido, T.; Iwata, R.; Watanabe, K. Improved synthesis of pure [F-18]fluoro-compounds for PET studies from bromo-compounds. Appl. Radiat. Isotopes 2003, 58, 557-566. 
152. DeGrado, T. R.; Bhattacharyya, F.; Pandey, M. K.; Belanger, A. P.; Wang, S. Y. Synthesis and Preliminary Evaluation of 18-F-18-Fluoro-4-Thia-Oleate as a PET Probe of Fatty Acid Oxidation. J. Nucl. Med. 2010, 51, 1310-1317.

153. Katritzky, A. R.; Suzuki, K.; Singh, S. K. N-acylation in combinatorial chemistry. Arkivoc 2004, 12-35.

154. Hugenberg, V.; Haufe, G. Oxidative Desulfurization-Difluorination of Alkyl Aryl Thioethers: Synthesis of $\omega$-Substituted 1,1-Difluoroalkanes. Synlett. 2009, 2009, 106-108.

155. Bucsi, I.; Torok, B.; Marco, A. I.; Rasul, G.; Prakash, G. K.; Olah, G. A. Stable dialkyl ether/poly(hydrogen fluoride) complexes: dimethyl ether/poly(hydrogen fluoride), a new, convenient, and effective fluorinating agent. J. Am. Chem. Soc. 2002, 124, 7728-7736.

156. Hugenberg, V.; Wagner, S.; Kopka, K.; Schober, O.; Schafers, M.; Haufe, G. Synthesis of geminal difluorides by oxidative desulfurization-difluorination of alkyl aryl thioethers with halonium electrophiles in the presence of fluorinating reagents and its application for $18 \mathrm{~F}$-radiolabeling. J. Org. Chem. 2010, 75, 608695.

157. Elsinga, P. H. Radiopharmaceutical chemistry for positron emission tomography. Methods 2002, 27, 208-217.

158. Zhu, X. F.; Williams, H. J.; Scott, A. I. An improved transient method for the synthesis of N-benzoylated nucleosides. Synth. Commun. 2003, 33, 1233-1243.

159. Guo, Z. W.; Gallo, J. M. Selective protection of 2 ',2 '-difluorodeoxycytidine (gemcitabine). J. Org. Chem. 1999, 64, 8319-8322.

160. Liang, T.; Neumann, C. N.; Ritter, T. Introduction of Fluorine and FluorineContaining Functional Groups. Angew. Chem. Int. Edit. 2013, 52, 8214-8264.

161. Hermida, S. A. S.; Possari, E. P. M.; Souza, D. B.; Campos, I. P. D.; Gomes, O. F.; Di Mascio, P.; Medeiros, M. H. G.; Loureiro, A. P. M. 2 '-Deoxyguanosine, 2 '-deoxycytidine, and 2 '-deoxyadenosine adducts resulting from the reaction of tetrahydrofuran with DNA bases. Chem. Res. Toxicol. 2006, 19, 927-936.

162. Tang, X. J.; Dmochowski, I. J. Phototriggering of caged fluorescent oligodeoxynucleotides. Org. Lett. 2005, 7, 279-282.

163. Plitta, B.; Adamska, E.; Giel-Pietraszuk, M.; Fedoruk-Wyszomirska, A.; NaskretBarciszewska, M.; Markiewicz, W. T.; Barciszewski, J. New cytosine derivatives as inhibitors of DNA methylation. Eur. J. Med. Chem. 2012, 55, 243-254. 
164. Kraszewski, A.; Delort, A. M.; Teoule, R. Synthesis of 4-mono- and dialkyl-2'deoxycytidines and their insertion into an oligonucleotide. Tetrahedron Lett. 1986, $27,861-864$.

165. Xu, B.; Stephens, A.; Kirschenheuter, G.; Greslin, A. F.; Cheng, X.; Sennelo, J.; Cattaneo, M.; Zighetti, M. L.; Chen, A.; Kim, S.-A.; Kim, H. S.; Bischofberger, N.; Cook, G.; Jacobson, K. A. Acyclic Analogues of Adenosine Bisphosphates as P2Y Receptor Antagonists: Phosphate Substitution Leads to Multiple Pathways of Inhibition of Platelet Aggregation. J. Med. Chem. 2002, 45, 5694-5709.

166. Yang, F.; Yu, L.; He, D. Y.; Yu, C. A. Protein-ubiquinone interaction in bovine heart mitochondrial succinate-cytochrome c reductase. Synthesis and biological properties of fluorine substituted ubiquinone derivatives. J. Bio. Chem. 1991, 266, 20863-9.

167. Hoertz, P. G.; Niskala, J. R.; Dai, P.; Black, H. T.; You, W. Comprehensive investigation of self-assembled monolayer formation on ferromagnetic thin film surfaces. J. Am. Chem. Soc. 2008, 130, 9763-9772.

168. Albanese, D.; Landini, D.; Penso, M. Hydrated tetrabutylammonium fluoride as a powerful nucleophilic fluorinating agent. J. Org. Chem. 1998, 63, 9587-9589.

169. Sawaguchi, M.; Hara, S.; Nakamura, Y.; Ayuba, S.; Fukuhara, T.; Yoneda, N. Deiodinative fluorination of alkyl iodide with p-iodotoluene difluoride. Tetrahedron 2001, 57, 3315-3319.

170. Belser, T.; Stohr, M.; Pfaltz, A. Immobilization of rhodium complexes at thiolate monolayers on gold surfaces: catalytic and structural studies. J. Am. Chem. Soc. 2005, 127, 8720-31.

171. Isomura, S.; Wirsching, P.; Janda, K. D. An immunotherapeutic program for the treatment of nicotine addiction: Hapten design and synthesis. J. Org. Chem. 2001, $66,4115-4121$.

172. Tucker, J. W.; Narayanam, J. M. R.; Shah, P. S.; Stephenson, C. R. J. Oxidative photoredox catalysis: mild and selective deprotection of PMB ethers mediated by visible light. Chem. Commun. 2011, 47, 5040-5042.

173. Vichai, V.; Kirtikara, K. Sulforhodamine B colorimetric assay for cytotoxicity screening. Nature Protocols 2006, 1, 1112-6.

174. Cappella, P.; Tomasoni, D.; Faretta, M.; Lupi, M.; Montalenti, F.; Viale, F.; Banzato, F.; D'Incalci, M.; Ubezio, P. Cell cycle effects of gemcitabine. Int. J. Cancer 2001, 93, 401-8. 
175. Ali, S.; Aranha, O.; Li, Y. W.; Pettit, G. R.; Sarkar, F. H.; Philip, P. A. Sensitization of human breast cancer cells to gemcitabine by the protein kinase $\mathrm{C}$ modulator bryostatin 1. Cancer Chemoth.Pharm. 2003, 52, 235-246.

176. Pulido, J.; Sobczak, A. J.; Balzarini, J.; Wnuk, S. F. Synthesis and Cytostatic Evaluation of 4-N-Alkanoyl and 4-N-Alkyl Gemcitabine Analogues. J. Med. Chem. 2014, 57, 191-203.

177. Yang, F. D.; Yu, L.; He, D. Y.; Yu, C. A. Protein-Ubiquinone Interaction in Bovine Heart Mitochondrial Succinate-Cytochrome-C Reductase - Synthesis and Biological Properties of Fluorine Substituted Ubiquinone Derivatives. J. Bio. Chem. 1991, 266, 20863-20869.

178. Pattison, F. L. M.; Hunt, S. B. D.; Stothers, J. B. Toxic Fluorine Compounds. IX.1 $\omega$-Fluorocarboxylic Esters and Acids. J. Org. Chem. 1956, 21, 883-886.

179. Pulido, J.; Sobczak, A. J.; Balzarini, J.; Wnuk, S. F. Synthesis and Cytostatic Evaluation of 4-N-Alkanoyl and 4-N-Alkyl Gemcitabine Analogues. J. Med. Chem. 2013, 57, 191-203. 
VITA

JESSE E. PULIDO

Born, Hialeah, Florida

2003-2008

B.S., Biology

Florida International University

Miami, Florida

2003-2010

B.A., Chemistry

Florida International University

Miami, Florida

2008

SoFLACS Graduate Travel Award

2008-2014

Doctoral Candidate

Florida International University

Miami, Florida

2011-2014

NIH/MBRS RISE Graduate Fellowship

Florida International University

Miami, Florida

\section{PUBLICATIONS AND PRESENTATIONS}

Winkle, S.; Dillon, A.; Landera, A.; Pulido, J.; Shaqra, A.; Wedderburn, L.; Sheardy, R. (April, 2008). RNA polymerase binds to specific nonpromoter DNA sequences. Poster presented at the $235^{\text {th }}$ ACS National Meeting \& Exposition, New Orleans, Louisiana.

Pulido, J.E.; Gattorno, J.; Ng, V.; Rao, T.; de la Vega, R.L.; Winkle, S.A. (March, 2009). Restriction enzyme activity studies of the binding of cisplatin to different DNA structures and sequences. Poster presented at the $237^{\text {th }}$ ACS National Meeting \& Exposition, Salt Lake City, Utah.

Winkle, S.A.; Duran, E.; Pulido, J.; Santil, G.; Talavera, M.; Winkle, C.; Sheardy, R.D.; Ramsauer, V. (2011). Examining flanking sequence specificity and topological specificity in the binding of various molecular types to DNAs using restriction endonuclease activity assays. Frontiers in Nucleic Acids: ACS Symposium Series, 1082, 167.

Pulido, J.; Sobczak, A.; Ortiz, H.; Van Dervort, A.; Theard, P.; Roy, D.; Wnuk, S. (March, 2012). Novel 4-N-modified gemcitabine analogs. Poster presented at the $243^{\text {rd }}$ ACS National Meeting \& Exposition, San Diego, California. 
Pulido, J.E.; Becker, D. A.; Quirke, J. C. K.; Quirke, J. M. E. (April, 2013). Photographic evidence for the mechanism and regiochemistry of Markovnikov and anti-Markovnikov additions of hydrogen bromide to alkenes. Poster presented at the $245^{\text {th }}$ ACS National Meeting \& Exposition, New Orleans, Louisiana.

Pulido, J.E.; Sobczak, A.J.; Balzarini, J.; Wnuk, S.F. (2014). Synthesis and cytostatic evaluation of 4- $\mathrm{N}$-alkanoyl and 4- $\mathrm{N}$-alkyl gemcitabine analogues. Journal of Medicinal Chemistry, 57 (1), 191-203.

Pulido, J.E.; Sobczak, A.J.; Balzarini, J.; Wnuk, S.F. (2014). Synthesis and cytostatic evaluation of 4- $\mathrm{N}$-alkanoyl and 4-N-alkyl gemcitabine analogs. Poster presented at the $247^{\text {th }}$ ACS National Meeting \& Exposition, Dallas, Texas. 